Universidade de São Paulo

Faculdade de Arquitetura e Urbanismo

Melissa Kikumi Matsunaga

CANTINHOS DO CÉU

São Paulo | 2015 



\section{CANTINHOS DO CÉU}

Dissertação de Mestrado apresentada à Faculdade de Arquitetura e Urbanismo da Universidade de São Paulo para a obtenção do título de Mestre em Arquitetura e Urbanismo.

Área de Concentração: Paisagem e Ambiente

Orientador: Professor Livre-docente Euler Sandeville Junior 
Autorizo a reprodução e divulgação total ou parcial deste trabalho, por qualquer meio convencional ou eletrônico, para fins de estudo e pesquisa, desde que citada a fonte.

Email da autora: melmatsunaga@yahoo.com.br

Exemplar revisado e alterado em relação à versão original, sob responsabilidade do autor e anuência do orientador. $\mathrm{O}$ original se encontra disponível na sede do Programa.

São Paulo, 30 de junho de 2015.

\section{FICHA CATALOGRÁFICA}

Matsunaga, Melissa Kikumi

M434c Cantinhos do Céu / Melissa Kikumi Matsunaga. --São Paulo, 2015. 215 p. : il.

Dissertação (Mestrado - Área de Concentração: Paisagem e Ambiente) - FAUUSP.

Orientador: Euler Sandeville Junior

1.Paisagem - São Paulo (SP) 2.Mananciais - São Paulo (SP)

3.Cantinho do Céu - São Paulo (SP) 4.Parque linear - São Paulo (SP)

5.Remoção de moradias - São Paulo (SP) I.Título

CDU 711.4.01(816.11) 
Nome: MATSUNAGA, Melissa Kikumi.

Tírulo: Cantinhos do Céu. Dissertação (Mestrado), Faculdade de Arquitetura e Urbanismo - FAU. Universidade de São Paulo. São Paulo: FAU USP, 2015.

Dissertação de Mestrado apresentada à Faculdade de Arquitetura e Urbanismo da Universidade de São Paulo para a obtenção do título de Mestre em Arquitetura e Urbanismo.

Aprovada em:

BANCA EXAMINADORA:

Prof.(a) $\operatorname{Dr}(a)$.

Instituição

Julgamento

Assinatura

Prof.(a) $\operatorname{Dr}(a)$

Instituição

Julgamento

Assinatura

Prof.(a) $\operatorname{Dr}(a)$.

Instituição

Julgamento

Assinatura 

Com muito amor e carinho dedico este trabalho aos meus pais,

Dona Vanilde e Seo Nelson 



\section{Agradecimentos}

Acredito que tive muita sorte de encontrar uma pessoa que me abriria uma porta importante nessa trajetória, que entendo não ser restrita apenas ao trabalho acadêmico aqui apresentado, mas ao percurso que vivenciei e que me reconduziu à Universidade. Agradeço, antes de tudo, ao arquiteto Marcos Boldarini, pela oportunidade em seu escritório, pela generosidade no ensino da prática profissional e, essencialmente, pela amizade. Sem dúvida, é dessa experiência profissional que a problematização desse trabalho surge e, nesse sentido, agradeço também à equipe de arquitetos colaboradores do escritório, muito atenta e sempre em grupo.

Agradeço a todos os entrevistados, moradores do Cantinho do Céu e do Lago Azul, que partilharam comigo suas histórias, dedicaram-me seu tempo, depositaram em mim confiança e sem os quais essa dissertação não seria possível. Devo agradecimentos e desculpas à arquiteta da SEHAB Violeta Kubrusly, cujo depoimento não inclui pela opção em utilizar apenas entrevistas de moradores dos bairros. Agradeço também à Sirlene Cheriato, arquiteta da JNS, pela conversa atenciosa em almoço no centro da cidade.

Ao orientador Prof. Euler Sandeville Jr., por me acolher em seu coletivo - antes mesmo de me conhecer - e que partilhou comigo de seus entendimentos não somente acadêmicos, como pessoais e cujos preceitos, formalizados na Espiral da Sensibilidade e do Conhecimento correspondem aos valores e afetos construídos no encontro e assim promovem um aprendizado permanente e que se renova continuamente. Agradeço por dividir sua janela comigo, me abrindo os horizontes, pela confiança, estímulo e paciência diante do fechamento do texto.

Agradeço carinhosamente aos amigos do NEP: Ana, Gabriel, Bel, Pati, Diego, Mari e Dani, pela troca e contribuição "alto astral" nas reuniões do grupo. Em especial à querida Ana Vellardi, cuja amizade cultivada em tempos amparenses foi atualizada na metrópole paulistana, sempre me auxiliando com seus conselhos cuidadosos e precisos. Agradeço às carinhosas Flores do Sul, Pri Ikematsu e Gabi Radoll, pela troca horizontal, pelo apoio e estímulo nesse final. À Pri que me ajudou com leituras atentas e conversões de arquivos mesmo depois de ter encerrado sua participação no grupo.

Às professoras Karina Leitão e Maria Eliza Miranda pelas contribuições críticas e valiosas realizadas na banca de qualificação.

À Rita Madureira, coordenadora social do Programa Mananciais da SEHAB-PMSP, que gentilmente disponibilizou lista de atendimentos realizados no Complexo Cantinho do Céu, além 
de ter indicado o contato da assistente social Nely, responsável pelo acompanhamento de pósocupação no Conjunto Mata Virgem, e que permitiu meu contato com moradores a serem entrevistados.

Agradeço à equipe do CEU Navegantes, em especial ao Adolfo (Ferruge) e Marcelo Sena, por me abrirem as portas do CEU e permitirem a realização de oficina de mapeamento com alunos da EE Maria Luiza.

Aos amigos que fiz em sala de aula da Maranhão: Laís Silveira, pela parceria nas idas a campo, pela troca, pela leitura atenta da dissertação e principalmente pelos comentários precisos e extremamente relevantes ao trabalho, que somente uma antropóloga poderia realizar. Ao Vinicius Souza, mestrando do Procam e atual administrador do Parque Linear Cantinho do Céu pela SVMA, pelas conversas animadas, pelo estímulo constante e pela companhia nas últimas visitas ao parque.

À família, meu porto seguro, aos meus pais Nelson e Vanilde, que sempre respeitaram minhas decisões e me apoiaram incondicionalmente, inclusive em momentos de aperto financeiro (que não foram poucos), facilitando muito minhas escolhas. Agradeço por estarem sempre junto a mim e me ajudando a encarar as dificuldades pessoais. Às minhas irmãs, Van e Pri, pelo convívio em família, ainda que escasso. Carinhosamente à Pri, que antes de ser minha professora particular com quem sempre pude contar, desde aspectos metodológicos, indicação de bibliografia até a leitura atenta e crítica dos artigos produzidos e da própria dissertação -, é um exemplo de conduta a quem procuro seguir.

Aos "roommates", Xande e Flávia, que forçosamente vivenciaram todo o processo, principalmente os momentos de angústia e que permitiram que eu transformasse a mesa de refeições do apartamento em mesa de escritório. De maneira especial ao Xande, que emprestou seu notebook quando o meu resolveu me abandonar num momento crucial do trabalho.

Às amigas do coração, que ouviram o desabafo em momentos de incerteza e frustração, além de serem pontos de apoio me fortalecendo com palavras de estímulo e vibrações positivas: Mari Santos, que especialmente reformulou o abstract com muita atenção e habilidade, e cuja objetividade é minha inspiração; Josi Viana e Lu Dornellas, parceiras de projetos e anseios por cidades mais justas e belas; Mel, amiga de infância, mais que querida, a quem devo atenção especial após meu afastamento nessa fase do mestrado; Ju Junko e Camila Souza, por me lembrarem de que os amigos sempre se lembram de você mesmo quando está ausente e, também, Danusa, por palavras de encorajamento em momentos de insegurança. 
Finalmente, e em especial, ao companheiro Leo, ainda que distante fisicamente, sempre presente, pelo apoio incondicional e por me acompanhar nessa empreitada desde o início. A quem devo principalmente desculpas pelas ausências e cobranças indevidas em momentos de angústia.

Ainda que a dissertação contenha lacunas de pesquisa e não apresente o devido grau de profundidade analítica que eu gostaria - o que é responsabilidade exclusivamente minha -, sem dúvida, sem o envolvimento e a participação de cada um de vocês, este trabalho não seria possível, deixo assim o registro do meu agradecimento e da minha sincera gratidão.

São Paulo, verão de 2015 quando a RMSP passa pela maior crise hídrica de sua história Coordenação de Aperfeiçoamento de Pessoal de Nível Superior (CAPES) para sua realização. 



\section{NOVOS DIAS}

"Este ano vai ser pior...

Pior para quem estiver no nosso caminho."

Então que venham os dias.

Um sorriso no rosto e os punhos cerrados que a luta não para.

Um brilho nos olhos que é para rastrear os inimigos (mesmo com medo, enfrente-os!).

É necessário o coração em chamas para manter os sonhos aquecidos. Acenda fogueiras.

Não aceite nada de graça, nada. Até o beijo só é bom quando conquistado.

Escreva poemas, mas se te insultarem, recite palavrões.

Cuidado, o acaso é traiçoeiro e o tempo é cruel, tome as rédeas do teu próprio destino. Outra coisa, pior que a arrogância é a falsa humildade.

As pessoas boazinhas também são perigosas, sugam energia e não dão nada em troca. Fique esperto, amar o próximo não é abandonar a si mesmo.

Para alcançar utopias é preciso enfrentar a realidade.

Quer saber quem são os outros? Pergunte quem é você.

Se não ama a tua causa, não alimente o ódio.

Por favor, gentileza gera gentileza. Obrigado!

Os Erros são teus, assuma-os. Os Acertos Também, divida-os.

Ser forte não é apanhar todo dia, nem bater de vez em quando, é perdoar e pedir perdão, sempre.

Tenho más notícias: quando o bicho pegar, você vai estar sozinho. Não cultive multidões.

Qual a tua verdade? Qual a tua mentira? Teu travesseiro vai te dizer. Prepare-se! Se quiser realmente saber se está bonito ou bonita, pergunte aos teus inimigos, nesta hora eles serão honestos.

Quando estiver fazendo planos, não esqueça de avisar aos teus pés, são eles que caminham.

Se vai pular sete ondinhas, recomendo que mergulhe de cabeça.

Muito amor, muito amor, mas raiva é fundamental.

Quando não tiver palavras belas, improvise. Diga a verdade.

As Manhãs de sol são lindas, mas é preciso trabalhar também nos dias de chuva.

Abra os braços. Segure na mão de quem está na frente e puxe a mão de quem estiver atrás.

Não confunda briga com luta. Briga tem hora para acabar, a luta é para uma vida inteira.

O Ano novo tem cara de gente boa, mas não acredite nele. Acredite em você.

Feliz todo dia!

SÉRGIO VAZ 



\section{RESUMO}

Este trabalho compreende o estudo da paisagem dos bairros Cantinho do Céu e Parque Residencial dos Lagos, localizados na zona sul do município de São Paulo, sob a perspectiva dos seus moradores e ex-moradores, denominados vivenciadores. A abordagem privilegiada na pesquisa, portanto, reside num enfoque cultural, situado no encontro das pessoas e o espaço em que vivem. Os bairros supracitados localizam-se em área de mananciais da metrópole paulista, especificamente às margens da Represa Billings e são considerados assentamentos precários pelas políticas públicas recentes. No estudo, resgata-se desde o histórico de formação dos mesmos até os processos de intervenção urbana em curso, enfocando os efeitos e representações engendradas na produção do espaço. O estudo foi realizado a partir da associação entre pesquisa documental e pesquisa de campo: de um lado dados primários e secundários coletados, além da literatura sobre o tema. Por outro, fontes orais registradas na realização de entrevistas, conversas coletivas, além de vivências junto aos vivenciadores. Aspectos da vida cotidiana como: valores e afetos, práticas e estratégias de vida, conflitos e tensões são elaborados a partir das narrativas dos vivenciadores e, devido a essa condição, são tecidos através de perspectivas específicas. O trabalho estrutura-se em duas partes: a primeira aborda o tema do conflito historicamente constituído na região de mananciais, buscando os entendimentos já elucidados em trabalhos acadêmicos pertinentes ao assunto, recuperando o contexto no qual as narrativas tratadas na segunda parte dizem respeito. A segunda parte elabora, através de trechos de entrevistas, depoimentos e narrativas de vida, a temática da paisagem dos bairros estudados. Partindo da condição temporal na sua elaboração, essa segunda parte subdivide-se num primeiro momento à formação dos bairros estudados e, posteriormente, aos processos mais recentes, abordando, ainda, remoções e deslocamentos dos vivenciadores. Além disso, são elucidadas apropriações do parque linear construído onde outrora moravam famílias conferindo outras possibilidades de investigação ao contexto no qual os bairros se situam.

Palavras-chave: Paisagem. Mananciais. Cantinho do Céu. Parque Linear. Remoção de moradias. 
This dissertation comprises a landscape study of the neighborhoods Cantinho do Céu and Parque Residencial dos Lagos, from the perspective of their residents and former residents, called here as experiencers. The research lies in a cultural approach based on the meeting of the people with the space where they live. The aforementioned neighborhoods are located in a water source area of the metropolis of São Paulo, specifically on the banks of the Billings Reservoir, and they have been considered as precarious settlements by the recent public policies. In the study, the historical formation of these neighborhoods is rescued until the ongoing urban intervention processes, focusing on the effects and representations engendered in the production of space. The study was conducted combining desk research and field research: on the one hand, primary and secondary data were collected, in addition to the literature on the subject. Besides that, oral sources were recorded in interviews, collective conversations and experiences with the experiencers. Aspects of the daily life such as, values and emotions, practices and strategies of life, conflicts and tensions are drawn from the narratives of the experiencers, and because of this condition, are woven through specific perspectives. The work is organized in two parts: the first one deals with the conflict historically constituted in the water source region, searching for understandings already elucidated in academic papers related to the subject and recovering the context in which the narratives treated in the second part concern. The second part elaborates through excerpts from interviews, testimonies and life stories, the theme of landscape of the studied neighborhoods. Taking the temporal basis as condition in its preparation, this second part deals with two moments: at first, with the formation of the studied neighborhoods, and then, with the latest processes, house removals and displacements of the experiencers. In addition, appropriations of the linear park built where the families once lived, are elucidated, giving other research possibilities to the context in which the neighborhoods are stablished.

KeYwORDS: Landscape. Water source area. Cantinho do Céu. Linear park. House removal. 



\section{INTRODUC̣ÃO 21}

Objetivo, Percurso e Procedimentos 23

Paisagem vivida e partilhada 26

Ponto de partida: o campo 28

Os vivenciadores, suas narrativas, suas memórias 32

Estrutura do trabalho 33

PARTE I - OS MANANCIAIS 36

\section{CAPÍTULO O1 - MANANCIAL PROTEGIDO E IRREGULARMENTE OCUPADO 41}

1.1 Os conflitos do território 44

1.2 De um cantinho privilegiado e protegido pela lei ao Complexo Cantinho do Céu 53

1.3 Entre o Céu e a Água 61

\section{PARTE II - OS VIVENCIADORES 67}

\section{CAPÍTULO 02 - UM CANTINHO PARA CHAMAR DE MEU 71}

2.1 Num cantinho do céu 73

Seo João do peixe e Angela 84

2.2 O Parque Residencial dos Lagos 90

Dona Lourdes 96

2.3 Quando a casa vira parque 101

2.4 Trabalhar liderando ou liderar trabalhando 109

\section{CAPÍTULO O3 - O QUE NOS (RE)MOVE 111}

3.1 À paulistana 118

Lucia 118

3.2 Em busca do porto seguro 125

Débora 125

3.3 A família cresce 132

Seo Pedro e Cleonice 132

3.4 Informação breve e silenciada 140

Eunice e Carlos 140

3.5 Mudança de Padrão 143

O Conjunto Residencial Mata Virgem 143

Lucilene 144

3.6 Mande notícias da margem de lá 151

\section{À GUISA DE CONCLUSÃO 153}

Nota Final 157

A janela de Fátima 160

\section{REFERÊNCIAS BIBLIOGRÁFICAS 163}




\section{LEGISLAC̣ÃO 167}

Municipal 167

Estadual 167

Federal 168

Notícias de jornal 168

\section{LISTAS 169}

Lista de Abreviaturas e Siglas 169

Lista de Figuras 170

Lista de Gráficos 172

Lista de Quadros 172

\section{APÊNDICES 173}

Apêndice 1 - Atividades de campo 175

Apêndice 2 - Processo judicial - ACP 179

Apêndice 3 - Oficina CEU Navegantes 189

Apêndice 4 - Publicações, exposições e prêmios referentes à intervenção urbana 205

\section{ANEXOS 207}

Anexo A - Capa Revista VejaSP, de 19 de junho de 1991. "A São Paulo escondida" 209

Anexo B - Carta-denúncia anônima à Promotoria, de julho de 1994211 


\section{INTRODUC̣ÃO}

É como se você fosse andando, muito decidido, por um caminho reto e, aos poucos, fosse percebendo que ele ia se estreitando, mudando de características e virando um beco. Aí você acabava dando de cara com uma parede. As suas opções seriam: 1) - ficar parado, olhando para o obstáculo sem entender nada, desesperado e desanimado; 2) - esmurrá-lo na esperança de derrubá-lo a socos; 3) - declarar que só continuaria a andar quando chegasse o dia certo em que todas as barreiras cairiam e todos os caminhos passariam a ser livres e sem empecilhos e consolar-se com a ideia; finalmente, você poderia 4) - dar meiavolta, olhar na direção oposta e pensar - aqui começa tudo de novo. A última alternativa parece a mais simples. De fato não o é. Todos os fins trazem, implícito e embutido, um começo. Só que, para reconhecê-lo é preciso dar uma virada completa com a cabeça (SANTOS, 1980).

A experiência profissional me colocara em contato com o Cantinho do Céu nos idos de 2009. "Observar o familiar", nos termos de Gilberto Velho, é tarefa mais difícil que olhar para algo inicialmente desconhecido. A atividade acadêmica e de pesquisa, tradicionalmente, pressupõe o distanciamento e estranhamento para refletir sobre algo que me tocou e pelo qual tive grande envolvimento.

Entre os anos de 2008 e 2012 colaborei no escritório Boldarini Arquitetura e Urbanismo e, nesse período, dentre outros projetos, participei do Projeto Executivo de urbanização do Cantinho do Céu: na fase de finalização do projeto de Urbanismo (vias, pavimentação, vielas, remoções de edificações, adequações) e no trecho inicial do projeto de Paisagismo (parque linear). Diante de um longo processo de projeto e obra, com ampla divulgação da ação pública empreendida e várias exposições e prêmios conquistados' ${ }^{1}$ ficaram algumas lacunas a serem investigadas e que mereciam atenção. Uma grande inquietação se estabeleceu em relação aos moradores do bairro, principalmente aos que foram removidos de sua moradia. Colocou-se como necessário procurar saber os impactos da ação pública em suas vidas e trajetórias. E esta acabou se constituindo, depois de muitas idas e vindas, a grande questão da pesquisa. Nos riscos entre o que seria uma arquiteta realizando trabalho de campo, numa perspectiva antropológica, haveria facilmente equívocos quanto ao fazer etnográfico, sem formação e rigores desse campo disciplinar. No entanto, Santos (1980) já colocaria os limites de tal impasse, alertando para a necessidade de um recomeço.

\footnotetext{
${ }^{1}$ A midiatização da ação pública empreendida em meados de 2010 colocou em evidência o bairro no cenário urbanístico e arquitetônico, sendo o projeto apresentado em várias exposições e eventos nacionais e internacionais. Abordo sucintamente o projeto realizado no Capítulo 1. Para lista de publicações, exposições e prêmios ver Apêndice 4.
} 
Recomeço esse que pressupunha não apenas a observação de algo familiar a partir de seu distanciamento, mas, também o reenvolvimento com esse mesmo objeto.

Adoto então, no presente texto, o papel de narradora. Ter vivenciado essa experiência de certo modo me inseria também numa rede ou trama de relações e devido a essa condição, anular minha presença se tornou algo impossível de realizar. E, apesar de ser necessário um recomeço, não é possível apagar da memória a experiência que me trouxe até aqui, e que sem dúvida alguma, faz de mim ser quem sou.

A presente pesquisa está vinculada ao Núcleo de Estudos da Paisagem (NEP) do Laboratório de Espaço Público e Direito à Cidade (LABCIDADE) da Faculdade de Arquitetura e Urbanismo da Universidade de São Paulo e integra um conjunto de estudos e trabalhos desenvolvidos na região dos mananciais sul da Região Metropolitana de São Paulo (RMSP)².

Dentre outras abordagens, o NEP investiga a paisagem adotando a ideia de que:

Paisagens são experiências partilhadas pelas pessoas que têm nela sua vida, na qual o pesquisador, frequentemente um estranho ao lugar, se insere de modo muito específico e por tempo limitado, partilhando dessas experiências e partilhando as suas: usufruindo de um uma realidade essencialmente coletiva e de uma herança de gerações (SANDEVILLE, 2004:4).

Assim, nesta abordagem adotada pelo NEP, a metodologia de pesquisa parte do pressuposto do envolvimento do pesquisador através da pesquisa-participante para compreender a constituição e legitimação da paisagem em transformação.

Assumindo o pleonasmo na expressão "transformação da paisagem", reforço que o foco da pesquisa residiu então no mutável, instável, em constante modificação, principalmente quando o tema está inserido numa realidade urbana periférica, englobando os assentamentos precários ${ }^{3}$ do tipo loteamentos irregulares e clandestinos.

\footnotetext{
2 Os estudos na região de mananciais dos reservatórios Billings e Guarapiranga do Núcleo de Estudos da Paisagem (NEP), iniciaram-se com a participação no projeto de Políticas Públicas (FAPESP) coordenado pelo Programa de Pós-Graduação em Ciência Ambiental (PROCAM-USP). Realizado entre 2008 e 2010 nos municípios de Embu e Taboão da Serra, teve foco na Aprendizagem Social na gestão de recursos hídricos. Também foram realizados trabalhos de iniciação Científica, de conclusão de graduação (município do Embu, entre 2009 e 2010); e no Plano de Manejo dos Parques da Compensação do Rodoanel Trecho Sul, coordenado pelo Departamento de Geografia da Faculdade de Filosofia, Letras e Ciências Humanas (FFLCH-USP). Dessas atividades resultaram as primeiras pesquisas de pós-graduação na zona sul do município de São Paulo. Além dessa pesquisa, foram desenvolvidos os mestrados de Simone Miketen (2010-2013, sobre as áreas rurais em processo de conversão agroecológica no contexto urbano), de Priscila Ikematsu (2011-2014, sobre a gestão da bacia hidrográfica da Guarapiranga e de Gabriella R. Radoll (2011-2014, sobre as potencialidades para a criação de sistema de espaços públicos de conservação e lazer).

3 De acordo com o Guia para o Mapeamento e Caracterização dos Assentamentos Precários: "A expressão "assentamentos precários" foi adotada pela nova Política Nacional de Habitação (PNH) de forma a englobar, numa categoria de abrangência nacional, 0 conjunto de assentamentos urbanos inadequados ocupados por moradores de baixa renda, incluindo as tipologias tradicionalmente utilizadas pelas políticas públicas de habitação, tais como cortiços, loteamentos irregulares de periferia, favelas e assemelhados, bem como os conjuntos habitacionais que se acham degradados" (BRASIL, 2010:9).
} 


\section{Objetivo, Percurso e Procedimentos}

O objetivo da pesquisa foi estudar a paisagem do Cantinho do Céu através das narrativas de vida dos moradores, procurando entender como se relacionam com as dinâmicas urbanas, desde a constituição dos bairros até os processos de intervenção urbana em curso. São considerados como interlocutores os moradores, ex-moradores e lideranças comunitárias.

Definido esse objetivo, é importante destacar, também, o que não corresponde aos objetivos da pesquisa, no sentido de esclarecer como se pretendeu conduzir o trabalho. A problematização que se pretende não tem o intuito de abordar a relação da ocupação da área de mananciais da cidade de São Paulo e a ausência de política pública habitacional durante o processo dessa ocupação. Essa problematização já está dada por outros trabalhos acadêmicos, cujo tema constitui uma linha de pesquisa consagrada na Faculdade de Arquitetura e Urbanismo da Universidade de São Paulo. ${ }^{4}$ Utilizo-os no presente trabalho para compreender o contexto mais amplo dos processos vigentes no bairro, uma vez que o interesse localiza-se na escala local, no âmbito da vivência cotidiana onde, sem dúvida, esses conflitos fazem parte e o condicionam.

Também não foi intenção fazer uma avaliação ou análise do projeto realizado. A prática profissional já me permite indicar considerações a serem feitas nesse sentido, como a necessidade de valorização profissional frente a decisões de projeto, a necessidade do fortalecimento da intersetorialidade e interdisciplinaridade na árdua tarefa de urbanizar favelas, dentre outras tantas críticas possíveis de serem feitas quando se vivencia as contradições e limites de ser apenas um dos agentes numa cadeia/rede complexa de atores institucionais em torno de um objetivo comum.

Inicialmente, a pesquisa se propunha a estudar o Cantinho do Céu a partir de duas escalas de análise, sendo uma geral e outra local. Muito comum ao arquiteto, esse olhar, a partir de diversas escalas, ao mesmo tempo necessário, é um dificultador na medida em que exige entrelaçar e reconhecer o imbricamento entre os processos que ocorrem nas diversas escalas - e demandam abordagens distintas - relacionando legislação, políticas, programas e ações públicas com os sujeitos locais.

É verdade que o caso do Cantinho do Céu pode ser considerado como mais um assentamento dentre tantos oriundos do processo de ocupação irregular da área de mananciais -

\footnotetext{
${ }^{4}$ Nesse arcabouço intelectual da FAUUSP, ver trabalhos de SOCRATES et al.,(1985); MOREIRA (1990); MARCONDES (1990); ANCONA (2002); MARTINS (2006); FERRARA (2014)
} 
tema abordado na primeira parte do trabalho - mas seria inadequado homogeneizar a configuração desse território e tratá-lo como um tipo ou modelo, o que tende a reduzir e anular sua própria origem e, portanto, sua relação com a cidade. A generalização reforça o risco de uma banalização, e ao assumir essa postura, além de nos retirarmos do cenário, perdemos a "escala humana", colocando os moradores como um dado, ou nem isso. Portanto, não é intenção abordar os processos, projetos ou planos por suas lógicas e valorações internas, e sim as pessoas em relação a esses mesmos processos, projetos ou planos e, ainda, os efeitos em suas vidas.

Para tanto, procurei contextualizar as implicações das diversas escalas no que acontecia no bairro, e o que me interessava, com grande exatidão, era como as pessoas se relacionavam com tais acontecimentos, se apropriavam deles ou não. Simultaneamente à pesquisa de campo, realizando as entrevistas, de modo à deriva - já que a possibilidade de entrevista surgia de uma entrevista anterior, onde os interlocutores entrevistados me indicavam possíveis depoentes - a revisão bibliográfica sobre o tema e a área estudada ampliaram as possibilidades de estudo.

A tese de doutorado da Profa. Maria Eliza Miranda em 2002 forneceu pistas importantes no delineamento da presente pesquisa exatamente por apresentar dados, informações e entrevistas com depoentes em comum, como a Dona Florípes, por exemplo. O trabalho da professora do departamento de Geografia da FFLCH-USP aborda a constituição do Cantinho do Céu como resultante de práticas sociais e políticas de tendências ideológicas variadas, relacionado ao contexto político da redemocratização das décadas de 1980 e 1990, quando os problemas de habitação e os de meio ambiente foram tratados de maneira diferenciada, tanto em nível de abordagem quanto em nível de escala. Além disso, o bairro constituira-se a partir de agentes políticos locais, apresentando com isso, segundo a professora, "aspectos sombrios e obscuros" na ocupação irregular do bairro, ou seja, relacionando interesses políticos em relação aos domínios de poder daquela região da cidade. Lembrando que, no momento da sua pesquisa, o Cantinho do Céu havia sido incluído no Plano Emergencial (Decreto Estadual no 43.022/1998) da Lei de Proteção e Recuperação dos Mananciais (LPRM - Lei no 9.866/1997) e nesse contexto, ela estabelece as possibilidades de aprovação do parcelamento e sua regularização.

Uma década após o trabalho de Miranda (2002), faz-se necessário atualizar os agentes e a própria condição do bairro. Nesta perspectiva, o trabalho aqui apresentado incorpora suas elaborações e de outros estudos sobre a área de mananciais, para compreensão dos processos políticos vigentes: da complexidade de relações políticas locais e institucionais, de uma nova lei 
promulgada (LPRM de 1997) e do projeto urbanístico que começou a ser implantado (2008), alterando as dinâmicas urbanas na região e incidindo diretamente na trajetória de vida das pessoas.

É preciso atentar para o período histórico para entender a ocupação do território em questão até a implementação do projeto e da intervenção realizada. Resgato sucintamente, desde as primeiras ocupações na região, o entendimento dessa ocupação em problema "ambiental" até a consecução das obras de urbanização integrada em curso.

Uma importante fonte de informação foi o Processo Judicial $\mathrm{n}^{\circ}$. 040529244.1997.8.26.00535 referente à Ação Civil Pública (ACP) ajuizada pelo Ministério Público de São Paulo em fevereiro de 1997, que colocou aos Poderes Executivos Municipal e Estadual a necessidade de adequação do assentamento à legislação vigente, o que naquele momento (1997), correspondia a sua completa remoção, sob pena de multa diária além de outras sanções legais. Apresento alguns aspectos do processo judicial no Capítulo 1.

A leitura de tal documento judicial iluminou alguns aspectos históricos importantes para compreensão da ocupação do território do Cantinho do Céu. Não perdendo de vista que o próprio Processo é uma 'versão' dos fatos, no entanto, pelo seu caráter público e representante de práticas sociais da nossa sociedade, constitui-se como uma fonte importante, já que envolve processos investigativos, depoimentos dos envolvidos e relatórios técnicos que elucidam a atuação do Poder Público Municipal e Estadual diante da problemática que se estabelecia desde início dos anos 1990. Cumpre destacar que a ACP é o auge de um processo que iniciou em 1994 a partir de uma cartadenúncia anônima onde foram relatadas várias práticas irregulares de ocupação do bairro, inclusive a inocuidade do próprio Executivo municipal na resolução dos conflitos fundiários em curso.

$\mathrm{Na}$ perspectiva de compreensão do processo de ocupação do território, os Autos do Processo - que até o momento não foi sentenciado - apresentam registros importantes, dentre os quais: matrículas das glebas existentes anteriormente à ocupação e depoimentos de antigos moradores do bairro que relatam a ocupação irregular e, ressalta-se, aqui que, posteriormente, algumas informações serão dispostas no Capítulo 2. Nesse contexto, motivado pela ACP, o projeto para o Complexo Cantinho do Céu - que corresponde ao perímetro de intervenção urbana - seria definido através de longa negociação com a Promotoria e surge com o objetivo de consolidação do

\footnotetext{
5 Processo judicial nº. 0405292-44.1997.8.26.0053 (336/97) referente à Ação Civil Pública ajuizada pelo Ministério Público de São Paulo em fevereiro de 1997. O Processo, até setembro de 2014 consta de um conjunto de 21 volumes, em trâmite na $4^{\text {a }}$. Vara de Fazenda Pública - Foro Central, no Fórum Hely Lopes Meirelles e fica à disposição para consulta no local, inclusive para cópias xerográficas e fotos, se necessário. Ver Apêndice 2.
} 
assentamento, removendo apenas as famílias cujas moradias estavam situadas em condição de risco e/ou localizadas à margem dos cursos d'água, prevendo a adequação à nova legislação ambiental.

Outra fonte fundamental para a pesquisa foi a lista das famílias atendidas no processo de remoção (entre 2008 e 2012). O material foi obtido junto à Coordenação Social do Programa Mananciais em julho de 2013. Esses dados foram parcialmente mapeados e demonstram os deslocamentos das famílias no território promovidos pela intervenção. Alguns apontamentos são realizados no Capítulo 3.

Convém esclarecer também que, inicialmente, o intuito era estudar a paisagem do Complexo Cantinho do Céu, que inclui três bairros: Cantinho do Céu, Parque Residencial dos Lagos e Jd. Gaivotas ${ }^{6}$ No entanto, como não tive inserção em campo neste último bairro, o presente trabalho limita-se ao estudo dos bairros do Cantinho do Céu e Parque Residencial dos Lagos somente. Este último é popularmente conhecido como Lago Azul. Salienta-se que o Jd. Gaivotas, que integra o Complexo, não foi tratado nessa pesquisa.

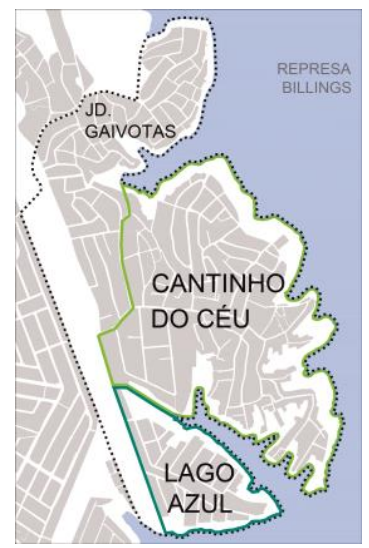

Figura 1 - Bairros estudados no Complexo Cantinho do Céu.

\section{PaISAgem VIVIDA E PARTILHADA}

A polissemia na qual está inserido o conceito de paisagem implica em inúmeras e distintas abordagens, desde a tradição pictórica, passando pelo patrimônio cultural até o estudo ecológico, uma vez que o termo possibilita que diversas áreas do conhecimento se envolvam com o tema (MENESES, 2002). Seguindo a trilha de Meneses (2002), que ressalta esse "caráter movediço do tema”, destaca-se aqui um enfoque cultural de relação com o meio, ressaltando a paisagem como interação, residindo, portanto, num caráter dinâmico e indissociável à sua própria definição. Nesse pressuposto, a mutabilidade é condição chave para sua interpretação.

Berque (1994) coloca que a paisagem "não reside somente no objeto, nem somente no sujeito, mas na interação complexa destes dois termos”. Assim, a paisagem estabelece-se como uma

\footnotetext{
${ }^{6}$ Alguns aspectos sobre o Jd. Gaivotas podem ser consultados nos trabalhos de Polli (2010) e Silva (2011). Sob óticas distintas de análise, as autoras estudam o caso do Jd. Gaivotas, quando o bairro em 2007, foi alvo do Programa Operação Defesa das Águas e, no âmbito deste Programa da Secretaria Estadual de Meio Ambiente, cerca de 100 famílias foram criminalizadas ambientalmente com remoções sumárias e violência simbólica por parte da Polícia Ambiental. Alguns anos posteriormente o bairro é incluído no perímetro do Complexo Cantinho do Céu, demonstrando, dentre outros aspectos, que a gestão dos problemas nas áreas de mananciais é resolvida de maneira contraditória pelas diferentes esferas de governo.
} 
relação, ela não é condição, nem suporte, não é somente o que se vê ou se contempla; a paisagem se situa na interação qualitativa entre o espaço e o sujeito. Para o autor, o entendimento de paisagem pressupõe, portanto, a conjugação de aspectos subjetivos (de quem a observa) e objetivos (do suporte, do ambiente). Adoto aqui, o entendimento de paisagem como ente relacional, sem pender ao dualismo, ou a algum desses aspectos exclusivamente.

Em relação ao sujeito constituinte da paisagem, Berque (1984/1998) considera-o como coletivo, aduzindo que "é uma sociedade, dotada de uma história e de um meio". Assim, a percepção em sua dimensão individual constitui apenas um elemento, devendo ser considerado não somente o indivíduo, "mas tudo aquilo pelo qual a sociedade o condiciona e o supera, isto é, ela situa os indivíduos no seio de uma cultura, dando com isso um sentido à sua relação com o mundo", ainda que esse sentido nunca seja o mesmo para cada um.

A conceituação de Sandeville Jr. $(2004,2005)$ amplia a ideia de paisagem adotada na pesquisa. Segundo este autor, a paisagem é entendida também como experiência e espaço socialmente construído. Dessa forma, ele considera como construção social não o mero reflexo nem suporte de sociedade, mas a própria expressão contraditória dessa sociedade no espaço, embora enfatize a dimensão afetiva e da experiência. Trata-se de uma experiência entre outros necessariamente. Outrossim, não se trata de mero subjetivismo, mas de uma compreensão existente na partilha de saberes locais e valores entre sujeitos e em processos sociais.

Inicialmente, para o estudo de paisagem, faz-se necessário perceber os modos de organização espacial. Porém, não podemos esquecer que além do aspecto morfológico pelo qual essa organização se expressa, a paisagem "é também uma sucessão de rastros, de pegadas que superpõem no solo e constituem, por assim dizer, sua espessura tanto simbólica quanto material" (BESSE, 2009/2014:33). E essa dimensão histórica, de herança coletiva, no curso da vida de seus protagonistas, também remete à paisagem como memória.

Do ponto de vista metodológico, Sandeville Jr. $(2004,2013)$ considera a paisagem como experiência partilhada, espaço vivenciado, da sensibilidade, cujo estudo exige o contato direto com as pessoas. Nessa perspectiva, tanto pesquisadores quanto as pessoas que tem nela sua vida são agentes que interferem na constituição do lugar, partilhando experiências intrínsecas à sua própria condição. Reafirma-se, desse modo, que cada paisagem tem aspectos singulares, com particularidades, e que seu sentido só é dado a partir do reconhecimento dessa realidade vivenciada.

Assim, colocou-se como necessário o entendimento das representações das pessoas entrevistadas, uma vez que seus depoimentos apoiam-se na memória, valoração e seleção dos 
acontecimentos e, neste ínterim, os registros apresentam-se como uma elaboração da situação vivida. Neste sentido, as narrativas aqui apresentadas são entendidas como representações, ou seja, elaborações construídas, que apesar de escolhas subjetivas na tessitura da narrativa, contribuem para elucidar as condições de vida no contexto estudado.

\section{PONTO DE PARTIDA: O CAMPO}

A visita ao Cantinho que considerei como primeira do universo das minhas idas a campo foi a mais difícil. Como eu já dispunha de alguns contatos, como por exemplo, Dona Vera liderança do Parque Residencial dos Lagos e Ferruge - coordenador cultural do CEU Navegantes, achei necessário iniciar de outro modo, que não contasse com essa "facilidade" predisposta. No início de 2013, havia um coletivo de jovens atuante no bairro Cantinho do Céu, do qual me aproximei. Estava marcada uma manifestação no bairro cobrando a Unidade Básica de Saúde (UBS) no local onde seria desapropriada uma chácara. Nesse dia, acompanhada de uma colega mestranda da antropologia, participamos do ato político e a minha inexperiência em pesquisas de campo (como me colocar, como me apresentar) acabou se transformando num enorme empecilho. Não me viam ali como alguém que pudesse contribuir e, sim, como um sujeito que estivesse espionando as ações do coletivo. O estranhamento ganhou tal dimensão que minha presença fora explicitamente anunciada como não bem-vinda. Aquele desastroso recomeço deixou-me assustada, mas com ele pude aprender que eu precisava dizer quem eu era, abertamente, e o que eu fazia ali. Assim, eu re-recomecei os campos procurando lideranças do bairro que eu não conhecia. A ideia de procurar as lideranças não era algo que me agradava como ponto de partida, pois além de já dispor de alguns contatos nesse sentido, compunham um grupo cujas representações poderiam configurar uma "cilada" da pesquisa. A natureza da liderança é falar/dizer em nome de um coletivo ou de um programa, e eu naquele momento ainda representava alguém do Poder Executivo Municipal, afinal, tendo participado do projeto do parque, era como se eu compusesse aquele grupo ${ }^{7}$.

Preciso dizer que foi uma transição lenta e gradual (essa da Melissa-arquiteta-quetrabalhou-no-projeto para a Melissa-pesquisadora-social) e, ao longo do próprio campo, percebi como o meu histórico comprometia as possíveis entrevistas e assuntos abordados. Viam-me como alguém que pudesse esclarecer dúvidas ou então ajudar a resolver o problema que estavam vivendo naquele momento.

${ }^{7}$ Abordo esse tema das lideranças no Capítulo 2, cuja atuação foi imprescindível no modo que os bairros foram ocupados. 
Dona Rosa, liderança do Cantinho do Céu - e que eu não conhecia inicialmente, cujo contato consegui através de uma indicação do CEU Navegantes - marcou o início da rede de interlocutores. Ela me recebeu em sua casa, onde posteriormente marcamos uma conversa coletiva com outros moradores convidados. E então a rede de interlocutores começou a se formar, cujo desdobramento apresento a seguir:

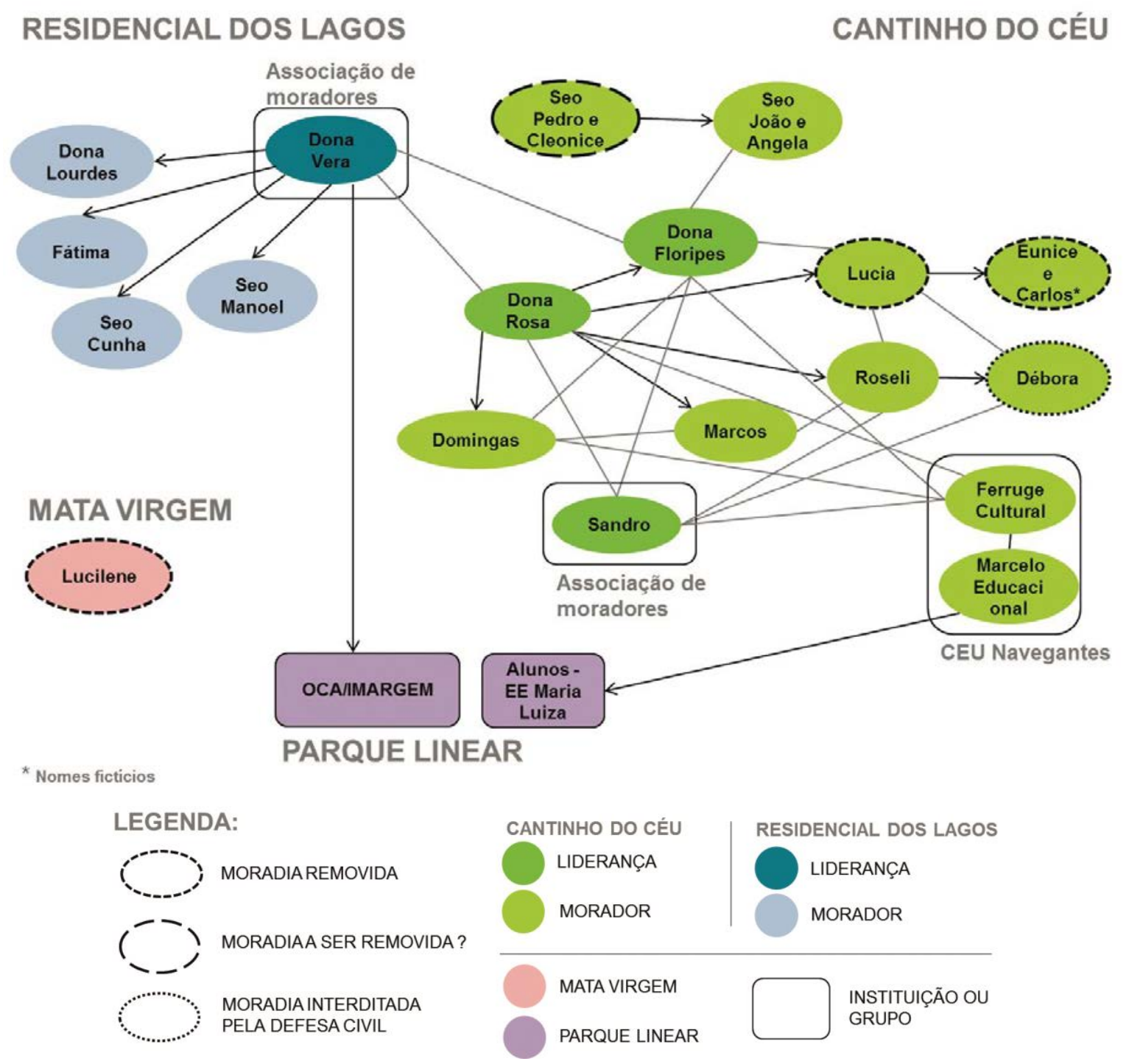

Figura 2 - A rede de interlocutores ${ }^{8}$.

Conforme o campo foi se desdobrando, fui também me sentindo mais próxima ao cotidiano da região: desde o percurso de trem realizado da Estação Pinheiros até o Terminal Grajaú, enfrentando o trânsito no trajeto da Av. Belmira Marin com destino ao Cantinho do Céu

${ }^{8} \mathrm{~A}$ rede de interlocutores aqui apresentada se utiliza de contribuições metodológicas das pesquisas de mestrado e doutorado de Cecilia Maria de Morais Machado Angileli, realizadas no distrito da Brasilândia, zona norte de São Paulo, entre os anos de 2004 e 2012. As conexões - das pessoas e dos lugares - articuladas em rede permitiram novas aberturas e possiblidades ao estudo da paisagem e suas representações, evidenciando o contexto específico de cada pesquisa (ANGILELI, 2007; ANGILELI, 2012). 
com obras de alargamento e corredor de ônibus até a chegada pela padaria "Vencedor" na esquina da Rua Francisco Inácio Solano, com barraquinhas de frutas, churrasquinhos, CDs e bebidas. O tempo gasto era de mais de duas horas na maioria das vezes.

Foi durante o trajeto do trem até o bairro que conheci "Seo" Pedro", e logo a conversa descompromissada na lotação abriu as possibilidades de agendarmos uma entrevista. Através de Seo Pedro, conheci Seo João, pescador do bairro e diria que o contato com esses dois amigos contribuíram para que o foco da pesquisa não ficasse apenas nas remoções, mas, também, a dividisse com quem continuava vivendo no bairro, do que é viver no bairro atualmente.

A pesquisa de campo (Ver Apêndice 1 - Atividades de campo) deu-se entre janeiro de 2013 e outubro de 2014, e ao longo desse processo, pude notar a definição de dois momentos: o primeiro era o estabelecimento da rede, com aproximações aos possíveis interlocutores e realização das primeiras entrevistas. No segundo momento, após a banca de qualificação, o campo se concentrou em aprofundar relações com alguns dos entrevistados, entender as dinâmicas em curso e a constituição de grupos, principalmente em relação ao bairro Residencial dos Lagos. Nesse último momento, também realizei oficina no CEU Navegantes com alunos da EE Maria Luiza.

Salienta-se aqui, na Figura 2, que a cor verde corresponde aos moradores do Cantinho do Céu, a cor azul os moradores do Residencial dos Lagos, a cor rosa os moradores do Conjunto Residencial Mata Virgem e a cor lilás representa o tema do parque linear tratado com tais interlocutores. Os que se encontram dentro de um polígono fazem parte de algum coletivo ou grupo (associação de moradores, escola ou coletivo cultural). Delimitei em tracejado longo quem estava sob possibilidade de remoção, em tracejado curto quem já havia sido removido pela intervenção e, em pontilhado, o caso de interdição pela Defesa Civil. As setas correspondem às indicações de contatos para realização das entrevistas e as linhas, ao fato de serem interlocutores conhecidos entre si.

Os assuntos abordados nas entrevistas variavam de acordo com os entrevistados. Sem dúvida, todas as histórias e vivências partilhadas têm a sua importância. Mas esclareço que alguns foram destacados, pois me apresentaram fatos que elegi importantes na composição do fio narrativo da dissertação. Apresento alguns trechos dessa troca de informações, lembrando que não se constitui como intenção contrapor as falas, e sim, entendê-las como constituintes da

${ }^{9}$ Em empréstimo linguístico de Guimarães Rosa, adotei ao longo da dissertação o termo Seo em substituição ao "Seu", como variante informal ao pronome de tratamento "Senhor". 
problemática estabelecida naquele momento na região em questão. Com certeza, não representam a totalidade do que ocorre no cotidiano e, sim, uma elaboração resultante do meu encontro com cada um deles.

As entrevistas foram gravadas em áudio, sendo que apenas as transcrições de algumas delas foram realizadas e sendo utilizados apenas alguns trechos dos depoimentos que problematizam a vivência e seu dia a dia.

1. Dona Rosa - Mauriceia Gaudencio Medeiros, 55 anos, liderança comunitária do Cantinho do Céu. Conversa conjuntamente com Dona Florípes, Roseli, Lucia, Domingas e Marcos em 02 de março de 2013.

2. Dona Florípes - Florípes Pereira Andrade, 60 anos, liderança comunitária do Cantinho do Céu. Conversa conjuntamente com Dona Rosa, Domingas, Roseli, Lucia e Marcos em 02 de março de 2013.

3. Lucia - Lucineia Angelo da Silva, 43 anos, moradora do Cantinho do Céu desde 1996. Foi removida em 2011 e continua morando no bairro. Primeiro contato em conversa conjuntamente com Dona Rosa, Domingas, Roseli, Domingas e Marcos em 02 de março de 2013. Posterior entrevista individual em 09 de julho de 2013, além de conversas por telefone e contato por redes sociais.

4. Roseli Mathias Barbosa, moradora do Cantinho do Céu desde 1997. Primeira conversa conjuntamente com Dona Rosa, Dona Florípes, Domingas, Lucia e Marcos em 02 de março de 2013. Posterior contato por redes sociais.

5. Marcos Uchôa do Nascimento, 22 anos, morador do Cantinho do Céu. Conversa conjuntamente com Dona Rosa, Dona Florípes, Roseli, Lucia e Domingas em 02 de março de 2013.

6. Domingas, moradora do Cantinho do Céu, agente de saúde. Conversa conjuntamente com Dona Rosa, Dona Florípes, Roseli, Lucia e Marcos em 02 de março de 2013.

7. Dona Vera, 62 anos, liderança comunitária do bairro Parque Residencial dos Lagos. Entrevista realizada em 31 de maio de 2013, além de conversas por telefone e redes sociais.

8. Ferruge - Adolfo Duarte, 32 anos, morador do Cantinho do Céu, coordenador cultural do CEU Navegantes. Entrevistas realizadas em 17 e 27 de março de 2013.

9. Fátima, 38 anos, moradora do Lago Azul desde os 14 anos. As paredes de sua casa começaram a rachar e o piso começou a ceder quando a casa vizinha começou a ser demolida. Entrevista realizada em 31 de maio de 2013.

10. Dona Lourdes, 73 anos, viúva, moradora do Lago Azul desde 1990. Entrevista realizada em 22 de junho de 2013.

11. Seo Pedro e Cleonice, 53 anos, moradores do Cantinho do Céu, estão construindo uma nova casa em Francisco Morato diante da possibilidade de sua remoção. Entrevista realizada em 02 de julho de 2013 além de conversas por telefone e visita posterior em 23 de setembro de 2014 .

12. Seo Manoel - Manoel Cavalcante de Lima, 67 anos, morador do Lago Azul, pedreiro já aposentado. Conversa conjuntamente com Seo Cunha e Dona Vera realizada em 16 de julho de 2013. 
13. Seo Cunha - José Eduardo da Silva, 56 anos, morador do Lago Azul, pedreiro, um dos primeiros moradores do bairro. Conversa conjuntamente com Seo Manoel e Dona Vera realizada em 16 de julho de 2013.

14. Seo João do peixe e Angela, ambos 40 anos, moradores do Cantinho do Céu desde 1992. Hoje Seo João vive do aluguel de casas no bairro e complementa a renda através do pescado diário. Ultimamente tem realizado passeios de barco pela represa pelo valor de $\mathrm{R} \$ 10,00$. Entrevista realizada em 27 de julho de 2013 além de conversas por telefone e visita posterior em 23 de setembro de 2014.

15. Eunice e Carlos (nomes fictícios), 37 e 34 anos respectivamente, tem 2 filhos, moram no Cantinho do Céu desde a remoção do Lago Azul em 2009, de onde moravam desde 2003. Entrevista realizada em 21 de setembro de 2013.

16. Sandro Mambelli, presidente da associação de moradores do Cantinho do Céu, sua família foi uma das primeiras do bairro. Mora na Chácara Cantinho do Céu que empresta o nome ao bairro em questão. Entrevista realizada em 24 de outubro de 2013.

17. Débora Roberta Souza Araújo, 35 anos, moradora do Cantinho do Céu desde 2005, tem 4 filhas sendo que 3 moram com ela. Sua casa foi interditada pela Defesa Civil em junho de 2012, hoje recebe auxílio aluguel no valor de $\mathrm{R} \$ 400,00$ e mora numa casa alugada no bairro. Primeira entrevista realizada em 12 de agosto de 2013, posteriores visitas e conversas por telefone e redes sociais.

18. Maria Lucilene Santos da Silva, 40 anos, 3 filhos, representante do Bloco B do Condomínio Residencial Mata Virgem - 2, ex-moradora do Lago Azul, onde residiu de 1994 a 2009. Entrevista realizada em 16 de agosto de 2014.

19. Tim, integrante do coletivo IMARGEM e organizador do coletivo OCA. Entrevista realizada em 24 de outubro de 2014.

20. Fifo, agente sócio cultural e organizador do coletivo OCA. Entrevista realizada em 24 de outubro de 2014 durante exposição de vídeo no parque linear.

\section{OS VIVENCIADORES, SUAS NARRATIVAS, SUAS MEMÓRIAS}

Existe, dentro da história cronológica, outra história mais densa de substância memorativa no fluxo do tempo. Aparece com clareza nas biografias; tal como nas paisagens, há marcos no espaço onde os valores se adensam (BOSI, 2004:24).

Considerei necessário no trabalho adotar o termo vivenciadores. Refere-se ao conjunto de moradores, ex-moradores, lideranças que vivem nos bairros estudados e são considerados agentes na paisagem em estudo. A noção de vivência amplia a noção de moradia, muito comum aos arquitetos, que entendem a moradia não restrita apenas à habitação, mas às condições dignas de morar, englobando a disponibilidade de serviços, infraestrutura e equipamentos públicos, além de condições de acessibilidade e localização adequada. A vivência engloba, além do ato de morar, dimensões afetivas, de práticas sociais, de atribuições de valores, ou seja, todas suas implicações na paisagem em questão, denotando um sentido ampliado da noção de moradia. Sendo assim, os 
depoimentos dos vivenciadores são de extrema importância para a análise da paisagem, uma vez que compreendem exatamente o espaço de conflito e tensão, de luta e conquista, de anseios e soluções que os bairros enfrentam ${ }^{10}$.

O procedimento das entrevistas e conversas vem informado da metodologia da história oral, conforme definição de Alberti (2004), não focando exclusivamente suas histórias de vida, mas sim os entrelaçamentos desses momentos e suas trajetórias e experiências em relação ao bairro. Aspectos da memória individual e coletiva são evocados na aplicação das entrevistas, que ora se dão coletivamente, ora de modo individual, mas sempre com o intuito de abordar a vivência e as percepções quanto à constituição do bairro e suas transformações em curso.

O conceito de memória coletiva de Halbwachs (1990) nos auxiliou no entendimento das falas, que embora individuais, estão imbuídas de significações coletivas e de correspondência a pertencimento de grupos sociais. Segundo Halbwachs (1990:51), “cada memória individual é um ponto de vista sobre a memória coletiva, que este ponto de vista muda conforme o lugar que ali eu ocupo, e que este lugar mesmo muda segundo as relações que mantenho com outros meios". O que nos atenta para o fato de que essas falas subjetivadas por essa dimensão social fazem-se a partir de significações coletivas no ato da lembrança, ou seja, no momento da rememoração. A entrevista se coloca, portanto, como o momento desse ato, onde são compartilhadas as experiências e evocadas as lembranças referentes ao que se viveu e implica atitudes perante a paisagem que contribuem para desvendar suas significações.

\section{ESTRUTURA DO TRABALHO}

A dissertação estrutura-se em duas partes, além desta Introdução e das Considerações Finais.

A primeira parte consiste num capítulo e aborda o tema sobre os mananciais buscando os entendimentos já elucidados em trabalhos acadêmicos pertinentes ao assunto, recuperando assim o contexto no qual as narrativas tratadas na segunda parte dizem respeito.

A segunda parte foi elaborada através de trechos de entrevistas, depoimentos e narrativas de vida a temática da paisagem dos bairros estudados. Inicialmente, é abordada a formação dos bairros estudados, Cantinho do Céu e Parque Residencial dos Lagos - conhecido localmente como Lago Azul -, e também, com foco neste segundo bairro, são elucidadas as apropriações em relação ao

${ }^{10}$ A adoção do termo vivenciadores resulta em empréstimo da tese de doutorado de Raul Pereira, em contraposição do termo usuários, por entender que o cidadão é um agente participante na paisagem (PEREIRA, 2007). Sandeville nos lembra que 0 termo viventes utilizado pelos situacionistas surge já nos anos 1960 em contraposição a ideia das pessoas como usuárias dos lugares. 
espaço público configurado pelo parque linear recentemente construído. Posteriormente, é tratado o tema das remoções e deslocamentos ocasionados pela intervenção em curso.

Assim, consiste na primeira parte apenas o primeiro capítulo: Manancial protegido e irregularmente ocupado - cujo conteúdo apresenta o entendimento dos processos urbanos existentes na região dos mananciais, entrelaçando aspectos gerais da urbanização paulistana, as políticas públicas incidentes no território e as dinâmicas locais. Retoma o histórico de ocupação da área de mananciais e como os conflitos foram se configurando ao longo do tempo com o crescimento urbano e as políticas públicas na tentativa de resolvê-los numa arena de disputas e interesses.

Abrindo a segunda parte, o segundo capítulo - Um cantinho para chamar de meu - trata a origem dos bairros estudados Cantinho do Céu e Parque Residencial dos Lagos, ou Lago Azul11, como é popularmente chamado, a partir da perspectiva dos vivenciadores entrevistados. Aborda também, as narrativas de vida de Seo João do peixe, pescador do bairro Cantinho do Céu e Dona Lourdes, moradora antiga e ex-liderança comunitária do Lago Azul. Ainda neste capítulo, são tratados os aspectos do cotidiano do parque linear construído no Lago Azul e o quanto a definição do espaço público no bairro suscitou potenciais apropriações e ressignificações do espaço.

O terceiro capítulo - O que nos (re)move - trata o tema da remoção e deslocamentos através de trechos de depoimentos de alguns vivenciadores envolvidos. Dentro de um contexto de precariedade urbanística e vulnerabilidade social, trato sobre suas narrativas e histórias de vida diante das incertezas e buscas por melhores condições. A primeira narrativa aborda Lucia, que fora removida pela intervenção realizada no Cantinho do Céu e continuava morando no bairro. Posteriormente, trato sobre a configuração do risco de morte associado à moradia de Debora e sua trajetória na resolução de seu conflito no bairro do Cantinho do Céu. Por outro lado, o deslocamento forçado e as dúvidas de sua concretização pelo projeto em curso aparecem na narrativa de Seo Pedro e Cleonice, moradores do Cantinho desde 1997. Um breve depoimento sugere o processo de remoção e negociação de Eunice e Carlos, ex-moradores do Lago Azul. E, ao fim, trago a narrativa de Lucilene, ex-moradora do Lago Azul, abordando seu deslocamento para o

\footnotetext{
${ }^{11}$ Como a denominação do bairro Lago Azul ou Parque Residencial dos Lagos reside numa tensão local do bairro que busca instituir sua identidade através da designação Parque Residencial dos Lagos, em contraponto ao fato de que a maioria das pessoas entrevistadas que residem no bairro ou na região o conhecem e o denominam como Lago Azul (que corresponde ao nome de uma das glebas que origina o bairro), no presente trabalho utilizo os dois termos. Assim, ao lidar com os entrevistados utilizo Lago Azul e quando a abordagem se refere ao bairro em relação ao entorno ou às ações implementadas no âmbito do Poder Público utilizo Parque Residencial dos Lagos. A postura em assumir a ambiguidade vem do campo.
} 
conjunto residencial Mata Virgem, destino proposto como alternativa às famílias removidas. Destarte, a temática é abordada realizando a justaposição de fragmentos narrativos com aspectos gerais do cotidiano vivido nos bairros.

Por fim, nas Considerações Finais, são trazidas análises e discussão em relação ao objeto de estudo e a importância da realização do campo na consecução da pesquisa.

Como elementos da pesquisa, achei importante deixar o registro dos subsídios que contribuíram para a elaboração da dissertação. O Apêndice 1 corresponde às atividades de campo, o Apêndice 2 contempla o processo judicial e o destaque de pontos relevantes, o 3 registra a oficina de mapeamento realizada com estudantes do Ensino Médio da E.E. Maria Luiza e o Apêndice 4 apresenta listas de publicações oficiais sobre a área e a intervenção realizada, incluindo exposições, eventos e prêmios referentes ao projeto de urbanização implementado no Complexo Cantinho do Céu. Constam ao fim, Anexos que correspondem a dados primários utilizados na dissertação. 



\section{PARTE I - Os MANANCIAIS}

Esta primeira parte da dissertação busca os entendimentos já elaborados sobre a constituição dos conflitos e impasses presentes na região dos mananciais ao sul da metrópole paulistana. Para tanto, entrelaço as políticas públicas de meio ambiente e de habitação, os instrumentos jurídicos incidentes no território, a atuação do Poder Judiciário e Poder Executivo (municipal e estadual) e o projeto de intervenção com obras em execução. Destarte, a linha do tempo ajuda a elucidar o processo nas diversas escalas. 



\section{LINHA DO TEMPO}

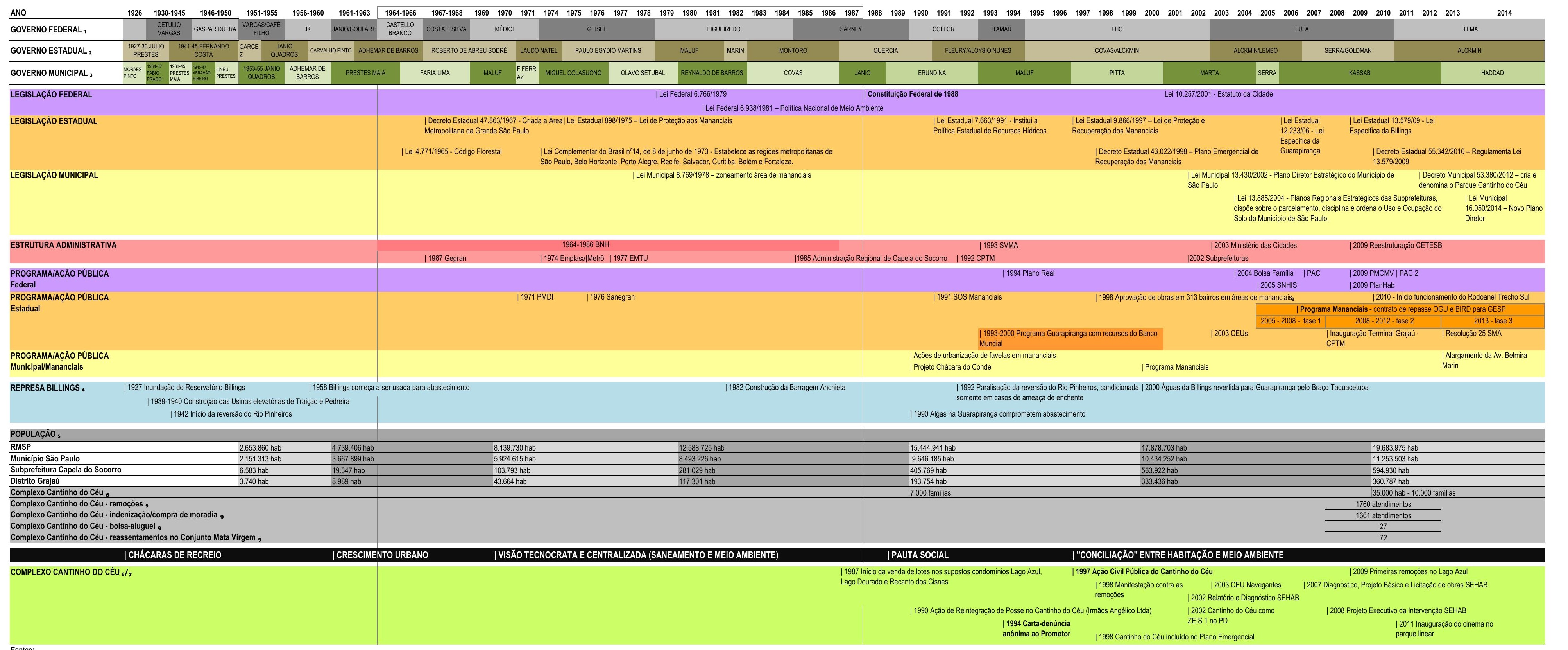

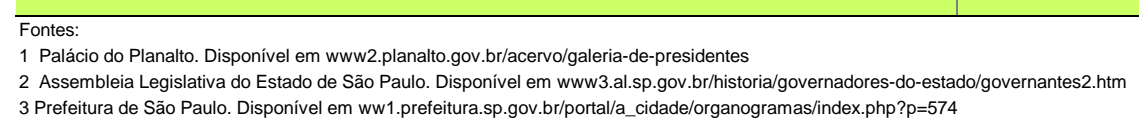

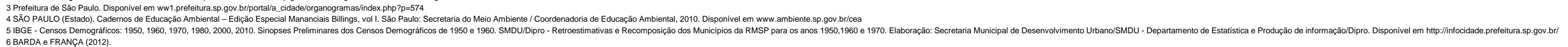
6 BAABDA FAANCA (2012).
7 Procosso Judicial ACP.

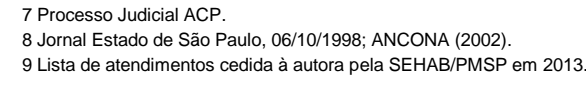




\section{CAPÍTULO 01}

\section{MANANCIAL PROTEGIDO E IRREGULARMENTE OCUPADO}

No âmbito acadêmico, sem dúvida, muito já foi discutido e publicado acerca da ocupação da área de mananciais e como o Estado tem enfrentado, através de políticas públicas, o conflito originalmente situado na problematização dual: direito à moradia x preservação dos recursos hídricos $^{12}$. Na busca por compreender a matriz discursiva estabelecida no território em questão, busca-se de modo sucinto percorrer o longo período histórico situando o debate e localizando assim o engendramento da política urbana na qual se originam os bairros estudados e sua construção social.

Resgatando os momentos históricos, pudemos perceber que o planejamento e as políticas públicas implementadas na região dos mananciais da metrópole paulistana começam a se configurar no sentido de preservação da qualidade da água para abastecimento público durante o regime ditatorial de 1964. A degradação da água, decorrente do crescimento urbano e populacional, já atingia altos índices quando a legislação que incide na área de mananciais é instaurada. A Lei de Proteção aos Mananciais (LPM), promulgada em 1975, durante a ditadura, encontrou ressonâncias no movimento social ambientalista que já se anunciava no início dos anos $1970^{13}$. Evocando a finitude dos recursos naturais e a poluição da represa pelo destino inadequado de efluentes, o binômio "saneamento e meio ambiente" colocou-se como indissociável nas políticas que se estabeleceram desde então (ANCONA, 2002; MARCONDES, 1990).

O processo de redemocratização e a garantia dos direitos políticos com a Constituição Federal de 1988 (CF/88) abriram as possibilidades de novas formas de participação, com atuação da sociedade civil organizada na ampliação do debate em torno dos problemas urbanos. Assim, a questão urbana seria pautada através de Emenda Popular pela Reforma Urbana na Assembleia Constituinte de 1987, incidindo nos Artigos 182 e 183 da CF/88, que estabelece a função social da propriedade e da cidade na política de desenvolvimento urbano a cargo dos municípios através da elaboração de planos diretores. A regulamentação dos artigos constitucionais foi longamente negociada tendo sua

\footnotetext{
12 Ver trabalhos de Marcondes (1990), Ancona (2002), Martins (2006), Santoro et al. (2008), Alvim (2011) e Ferrara (2014).

${ }^{13}$ Ancona (2002) aborda o momento de convergência entre a pauta ambientalista no Brasil com as políticas de crescimento econômico da ditadura. 0 movimento ambientalista mundial, como reação ao capitalismo industrial apresenta em sua constituição várias correntes divergentes, tanto de direita quanto de esquerda. A proposta de crescimento zero a ser aplicado aos países denominados de Terceiro Mundo era tido como solução para o desenvolvimento centralizado do capitalismo. No entanto, a Conferência das Nações Unidas em Estocolmo em 1972 ratifica o entendimento da pobreza como uma das causas da degradação ambiental e coloca princípios de um desenvolvimento sustentável, principalmente a esses países pobres. E é na defesa de um desenvolvimento sustentável que a legislação se apresenta.
} 
aprovação treze anos mais tarde, em 2001, com o Estatuto da Cidade - Lei Federal nº 10.257/2001 (MARTINS, 2006).

O que se percebe a partir de então é um jogo dual, permeado de ações controversas, com a emergência da questão social, pautando a questão urbana e as políticas públicas preservacionistas incidentes no território, com a necessidade premente de articulação setorial. O exemplo que elucida bem esse período é a ação do Ministério Público em exigir o cumprimento dos direitos ambientais, acionando o Poder Judiciário em ações de reintegração de posse e desfazimento dos assentamentos ao evocar o direito de propriedade no mesmo momento em que ações concretas de urbanização e saneamento já estavam em curso, vislumbrando uma articulação setorial entre ambas as pautas.

Se por um lado a dicotomia pode ter um papel organizador frente aos problemas e anseios da sociedade, ela também pode atuar como redutor da percepção da complexidade - incluindo a contraditoriedade - de relações estabelecidas por seus agentes. Miranda (2002) demonstra que estes predominavam entre os governantes e técnicos envolvidos com a questão nesse período recente, em que pesem esforços de uma articulação setorial, abordagens estanques: a pauta social não se articulava com a pauta ambiental e vice-versa ${ }^{14}$, e ainda hoje se estabelece uma realidade contraditória. A necessidade de intersetorialização já enunciada nesse momento indicaria certamente os descompassos a serem encontrados no horizonte próximo. Ainda que se reconheça atualmente que a qualidade da água como bem coletivo primordial à vida e que os assentamentos precários, pela falta de infraestrutura instalada contribuem para sua poluição - sem dúvida, não consistindo nos únicos fatores poluentes -, no senso comum, a dualidade expressa pela setorialização reforçou a polarização de que, de um lado, quem mora na área de mananciais é contra a preservação da qualidade da água e do outro, quem defende o manancial é contra a população residente.

Ademais, a dualidade delimitada apenas ao território entendido como 'área de mananciais' promove essencialmente o ocultamento sobre a carga poluidora advinda pelo canal Pinheiros, cuja reversão é recorrente até os dias atuais e que recebe efluentes da bacia hidrográfica do Alto Tietê. Segundo Carlos Eduardo Rocha, geógrafo da Empresa Metropolitana de Águas e Energia (EMAE), detentora e operadora do sistema de geração de energia elétrica da RMSP, afirma que:

Eu vejo as pessoas brigarem muito, principalmente da região do $A B C$, pela qualidade da água, só que a qualidade da água da Sub-bacia Billings depende também da Bacia do Tamanduateí, pois, no processo de reversão do fluxo dos

${ }^{14}$ Miranda (2002) compõe depoimentos de Luiza Erundina, Prefeita do Município de São Paulo entre os anos 1989 a 1992 e Fábio Feldman, Secretário de Meio Ambiente do Estado de São Paulo na década de 1990 (MIRANDA, 2002:77-79). 
Rios, a água é retirada do Tamanduateí, do Pinheiros e do Tietê e enviada para a Billings. Dessa forma, se esses Rios não forem tratados, a Billings também não será tratada (SMA, 2010:57).

Dados do relatório 2013 da Cetesb ${ }^{15}$ demonstram que a Unidade de Gerenciamento de Recursos Hídricos (UGRHI) n ${ }^{\circ} 6$ - correspondente à Bacia Hidrográfica do Alto Tietêำ, coleta $88 \%$ e trata apenas $54 \%$ dos esgotos domiciliares e que o corpos receptores da bacia são os rios Tietê, Rio Pinheiros e Rio Tamanduateí, sendo responsável por mais da metade da carga poluente lançada nos corpos d'água do Estado. Segundo o relatório: “Em função da concentração de população na RMSP e dos índices de saneamento, a carga remanescente do Alto Tietê de 633 t DBO ${ }^{17}$ dia-1 é responsável por 54\% da carga lançada nos corpos hídricos do Estado de São Paulo" (CETESB, 2013:26).

Dados da Fundação Seade, cruzados em 2008 com informações da Secretaria Municipal de Habitação de São Paulo, demonstram que o número de habitantes domiciliados em assentamentos precários em áreas de mananciais representam 6\% do número aproximado de $32 \%$ de habitantes em assentamentos precários no município, ou seja, as ocorrências de assentamentos precários, em sua maioria - mais de 3/4 dos habitantes domiciliados em assentamentos precários -, localizam-se fora da área de mananciais (Ver Quadro 1).

\begin{tabular}{|c|c|c|c|c|c|}
\hline \multirow[t]{2}{*}{ Favelas } & Mananciais & 247 & 56.176 & 228.159 & \\
\hline & Total & 1.573 & 377.236 & 1.539.271 & $14,21 \%$ \\
\hline Núcleos & Mananciais & 78 & 14.143 & 57.579 & \\
\hline \multirow{3}{*}{$\begin{array}{l}\text { Loteamentos } \\
\text { irregulares }\end{array}$} & Mananciais & 325 & 94.850 & 359.319 & \\
\hline & Fora de mananciais & 910 & 389.389 & 1.424 .243 & \\
\hline & Total & 1.235 & 484.239 & 1.783 .562 & $16,46 \%$ \\
\hline \multicolumn{2}{|c|}{ Total Geral } & 3.030 & 892.277 & 3.448 .234 & $31,83 \%$ \\
\hline \multicolumn{2}{|c|}{ Total de Assentamentos Precários em Mananciais } & 650 & 165.169 & 645.057 & $5,95 \%$ \\
\hline
\end{tabular}

Quadro 1 - Total de domicílios e habitantes em Assentamentos precários - São Paulo, 2008. Fonte: Habisp: Mapeando a habitação na cidade de São Paulo. Secretaria de Habitação. Superintendência de Habitação Popular. São Paulo, 2008:58.

${ }^{15}$ Relatório de Qualidade das Águas Superficiais no Estado de São Paulo, 2013, CETESB.

${ }^{16}$ As UGRHIs foram definidas pela Lei Estadual 9.034/1994, em consonância à Lei Estadual 7.663/1991, que dividiu 0 território do Estado de São Paulo em 22 unidades hidrográficas de gerenciamento de recursos hídricos.

17 "O DBO - Demanda Bioquímica de Oxigênio - é um indicador padronizado do grau de poluição orgânica em uma amostra de água. Indica a quantidade necessária de oxigênio dissolvido para a degradação biológica da mesma até uma forma inorgânica estável. Os esgotos domésticos apresentam DBO na faixa de 200 a $350 \mathrm{mg} / \mathrm{l}$. Os maiores aumentos de DBO em um corpo d'água, são provocados por despejos de origem predominantemente orgânica. A presença de um alto teor de matéria orgânica pode induzir à completa extinção do oxigênio na água, provocando o desaparecimento de peixes e outras formas de vida aquática. Um elevado valor da DBO pode indicar um incremento da microflora presente e interferir no equilíbrio da vida aquática, além de produzir sabores e odores objetáveis" (YAZAKI, 2008). 
De posse de tais dados e entendendo os mesmos como uma tendência, já que envolve apenas dados do município de São Paulo sem considerar outros municípios da RMSP inseridos na UGRHI 6, sugere-se aqui que, ainda que a urbanização dos assentamentos localizados em mananciais representem esforços no sentido de preservação da qualidade da água para abastecimento, é importante debater e analisar para além do território delimitado atualmente como de proteção ambiental (sub-bacia da Billings), buscando o foco não apenas nos assentamentos precários localizados na área de mananciais e, sim, todo um sistema ineficiente de esgotamento sanitário da RMSP.

A partir do entendimento de que essa questão deva ser tratada para além do conflito originalmente situado na questão da moradia x política ambiental (ou de saneamento), ainda que se pontuem argumentos de ambos os lados, no presente capítulo, resgata-se o histórico desse processo, evidenciando o contexto e apontando a amplitude de questões permeadas pela dicotomia e seus enfrentamentos nas práticas realizadas. Essa postura exige um olhar atento, buscando os entrelaçamentos do histórico da ocupação que se situa numa escala local frente às escalas regionais, tratando as legislações e políticas não só ambientais como, também, as sociais, os usos atribuídos ao manancial e a atuação do Estado na resolução (ou não) desse conflito.

\subsection{OS CONFLITOS DO TERRITÓRIO}

A ocupação da área dos mananciais, localizados na porção sul da metrópole paulistana, não é fenômeno novo, uma vez que tem sua origem antes mesmo da área ser definida como tal. A região localizada entre os lagos da Guarapiranga, com reservatório inundado em 1908, e da Billings, em 1927 - batizada por Interlagos em referência à Interlaken suíça -, começou a ser ocupada na primeira metade do século XX (REIS FILHO, 1994). Até 1935, essa região pertencia ao município de Santo Amaro, quando foi anexada com propósitos econômicos ao município de São Paulo ${ }^{18}$. Com a presença das duas represas, percebeu-se logo que a região apresentava grande potencial econômico com chácaras de recreio e usos de lazer, e cujos melhoramentos viários seriam realizados junto a esses empreendimentos. De início, podemos citar a Riviera Paulista, empreendimento de 1932, às margens da Represa de Santo Amaro (atual Guarapiranga). No

${ }^{18}$ Decreto Estadual $n^{\circ} 6.983$, de 22 de fevereiro de 1935 - Extingue o município de Santo Amaro, cujo território passa a fazer parte do município da Capital. 
interflúvio das represas, temos em 1938, com parcelamento do solo nos padrões de cidade jardim, o Balneário Satélite Interlagos ${ }^{19}$ e o autódromo de Interlagos em 1939. Num segundo momento, atrelado ao polo industrial da região de Santo Amaro, parcelamentos para a população trabalhadora também começaram a surgir e, com isso, tem-se como exemplo o parcelamento de habitação popular, Cidade Dutra em 1959 (BONDUKI e KOURY, 2014).

O conflito que começa a se constituir na ocupação desse território tem origem no agravamento da crise habitacional em São Paulo, que se tornou evidente a partir dos anos 1940 com o surgimento das primeiras favelas e a consolidação do processo de expansão periférica associada à autoconstrução pelas famílias de baixa renda (BONDUKI, 1998). Relacionado ao desenvolvimento econômico de base industrial nas décadas de 1950 e 1960, o rápido crescimento populacional urbano - passando de pouco mais de 500 mil habitantes em 1920 para quase 4 milhões de habitantes em $1960^{20}$ - associado à ausência de uma política pública habitacional eficiente, fortaleceram o movimento em direção às áreas periféricas - processo de crescimento urbano conhecido a partir do trinômio "loteamento periférico-casa popular-autoconstrução" (BONDUKI, 1998). Em contraposição à valorizada área central da cidade, as áreas periféricas vazias e sem infraestrutura, constituíram-se na alternativa de moradia para a população de baixa renda (MARTINS, 2006; SANTORO et al., 2009).

No entanto, não apenas de investimentos privados e ocupações irregulares a porção sul do município é produzida. Segundo Meyer et al. (2004), o padrão periférico de urbanização teve grande contribuição do poder público nos anos 1970, com a implantação de grandes conjuntos habitacionais de interesse social nas periferias metropolitanas. Como exemplo na região, temos o conjunto habitacional $\mathrm{COHAB}$ - Brigadeiro Faria Lima, popularmente conhecido como BNH do Grajaú - de grande imponência na paisagem (Ver Figura 3). Apesar do grande impacto nas áreas periféricas, esses conjuntos habitacionais não foram acompanhados de investimentos de mobilidade e equipamentos públicos, como educação, saúde, cultura e lazer, mostrando que a precariedade já era inerente do processo de urbanização periférico da metrópole.

\footnotetext{
${ }^{19}$ Perímetro foi tombado em 2004 pelo órgão de preservação municipal. Resolução CONPRESP 18/2004.

${ }^{20}$ Fonte: IBGE, Censos demográficos.
} 


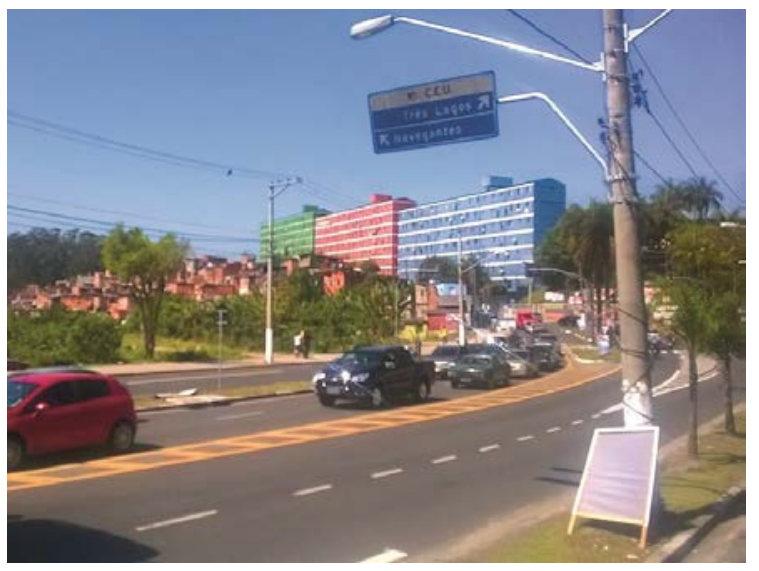

Figura 3 - COHAB Brigadeiro Faria Lima. Crédito: Melissa Matsunaga, 2014.

Se o espraiamento da ocupação já se configurava num ritmo acelerado, a partir dos anos 1970, é preciso destacar o papel da legislação de caráter preservacionista dos recursos hídricos que abastecem a metrópole nesse conflito (Leis Estaduais $\mathrm{n}^{\circ} .898 / 75, \mathrm{n}^{\circ}$. 1.172/76 e Decreto $\mathrm{n}^{\circ}$. 9.714/77). O novo ordenamento jurídico vai contribuir para o acirramento da situação de precariedade urbanística uma vez que, definindo a bacia hidrográfica ao qual o manancial está inserido como área protegida, estabelecerá densidades de ocupação sob o viés de um planejamento ideal, sem considerar a ocupação já existente de muitas áreas. Ademais, além do caráter restritivo, a política ambiental não efetivou mecanismos de fiscalização e nem articulação com outras políticas públicas em curso, como a habitacional.

Resgatemos sob o ponto de vista do manancial esse processo. O início do século XX é marcado por grandes mudanças no âmbito do planejamento urbano e dos investimentos de grandes sistemas de infraestrutura. Para regularizar a vazão do Rio Tietê e possibilitar o aumento de geração de energia elétrica na Usina de Parnaíba, a represa Guarapiranga foi construída em 1906, começando a operar em 1908²1. Em 1925, o Projeto Serra de Cubatão, que formaria a Represa Billings, começa a ser estudado para gerar energia elétrica na Baixada Santista. A represa Billings, batizada com o nome de seu idealizador, fazia parte de um complexo e ousado projeto, denominado Projeto Serra de Cubatão, ou Projeto da Serra, cujo objetivo era aproveitar o desnível de aproximadamente $720 \mathrm{~m}$ para abastecer o polo industrial da Baixada Santista com a geração de

${ }^{21} \mathrm{O}$ represamento do Rio Guarapiranga, também chamado Rio Embu-Guaçu, um dos formadores do Rio Pinheiros que, por sua vez, deságua no Rio Tietê, consistia em contribuir para o aumento da capacidade de geração de energia elétrica da Usina de Parnaíba, hoje chamada Usina Edgard de Souza, na cidade de Santana do Parnaíba, que represa, por sua vez, as águas do Rio Tietê. Esta Usina, construída em 1901 teve sua capacidade aumentada em 1912, num momento de aumento significativo de indústrias na cidade de São Paulo, além de crescimento populacional. Dentre vários trabalhos que abordam a história da Represa Guarapiranga, ver França (2000). 
energia elétrica através da Usina Henry Borden²2. Assim, em 1927, as obras do projeto de geração de energia elétrica na Baixada Santista, através da reversão e represamento do Rio Grande, vertendo para o Reservatório Rio das Pedras ${ }^{23}$ seria finalizado, formando o reservatório Billings. Nesse mesmo ano, alterações ${ }^{24}$ do projeto Serra de Cubatão, diante dos altos custos e a crescente demanda para o setor energético, implicariam na proposta da reversão do Rio Pinheiros através de sua canalização e estações elevatórias com bombas para aumentar a capacidade de armazenamento de água da Represa Billings e, consequentemente, elevar a capacidade de geração de energia. Além dos interesses econômicos vinculados à proposta de canalização do Rio, iniciada em 1937, essa alteração estava conectada também ao mecanismo de drenagem de modo a evitar enchentes na cidade já consolidada, com a estrutura de Retiro - no encontro entre os Rios Tietê e Pinheiros, seccionando suas bacias - e as usinas elevatórias de Traição e Pedreira, no canal do Pinheiros (FILARDO, 1999; SEABRA, 1987). Antes disso, em 1928, as águas da Guarapiranga começariam a ser utilizadas para abastecimento público, iniciando a sobreposição de funções desse manancial. As águas da Billings começariam a abastecer a metrópole em 1958, com ponto de captação em São Bernardo do Campo. Em virtude da contaminação do manancial da Billings, principalmente pelos efluentes domésticos da sub-bacia e da reversão do Rio Pinheiros, em 1982, é construída a Barragem de Anchieta, com o intuito de preservar o braço da represa onde se localiza esse primeiro ponto de captação da água para abastecimento. No ano 2000, as águas da represa Billings seriam transferidas para a represa Guarapiranga em outro ponto de captação, no braço do Rio Taquacetuba, tendo em vista a ampliação do sistema de abastecimento de água.

Na década de 1970, a discussão sobre a preservação dos mananciais atrelada ao Plano Metropolitano de Desenvolvimento Integrado (PMDI), cuja diretriz de crescimento urbano era orientado no sentido leste-oeste, incide na Lei de Proteção aos Mananciais (LPM). Contraditoriamente ao PMDI, e principalmente à LPM, o Projeto de Saneamento Sanegran, aprovado no mesmo ano da lei protetiva dos mananciais - 1976 -, previa a represa como receptora de esgotos (VILLAS-BOAS, 1995:50). Instaura-se, assim, uma situação de crise permanente, revelando que a busca das soluções se tornou cada vez mais complexa, dada a interdependência dos

22 Sobre os argumentos técnicos e contexto histórico do Projeto Serra de Cubatão associado ao monopólio da concessão dos sistemas de transportes, energia elétrica, gás e telefonia da Light em São Paulo e que se estendiam ao Rio de Janeiro, ver Filardo (1999). Sobre o funcionamento atual da Usina Henry Borden, em Cubatão, ver Escames (2011).

${ }^{23}$ A Barragem de Rio das Pedras, que forma o Reservatório Rio das Pedras, foi inaugurada em 1925 (ESCAMES, 2011:101).

${ }^{24}$ As alterações do projeto consistiram em abandonar a proposta de tuneis e conexões subterrâneas entre os corpos hídricos, além de barragens na região do Alto Tietê, considerada naquele momento a região de Mogi das Cruzes (FILARDO, 1999: 53-68). 
sistemas atrelado aos usos da represa e, consequentemente, o número de órgãos responsáveis (SOCRATES et al., 1984) - muitas vezes atuando descompassadamente na disputa de projetos políticos antagônicos, como foi o caso da LPM e o Sanegran.

A partir do estabelecimento de uma ocupação populacional máxima admissível da bacia hidrográfica, a LPM preconizava densidades de ocupação, relacionando usos permitidos em duas categorias: áreas de $1^{\mathrm{a}}$. categoria onde as restrições de uso do solo são maiores e as de $2^{\mathrm{a}}$. categoria, mais permissiva. Nesta última, os usos permitidos variavam de acordo com a proximidade ao manancial, sendo então a $2^{\text {a }}$ categoria subdividida em classes: A - área urbana, B - área de $\begin{array}{lllllllll}\text { expansão } & \text { urbana } & \mathrm{e} & \mathrm{C} & - & \text { área } & \text { rural } & \text { (Ver }\end{array}$

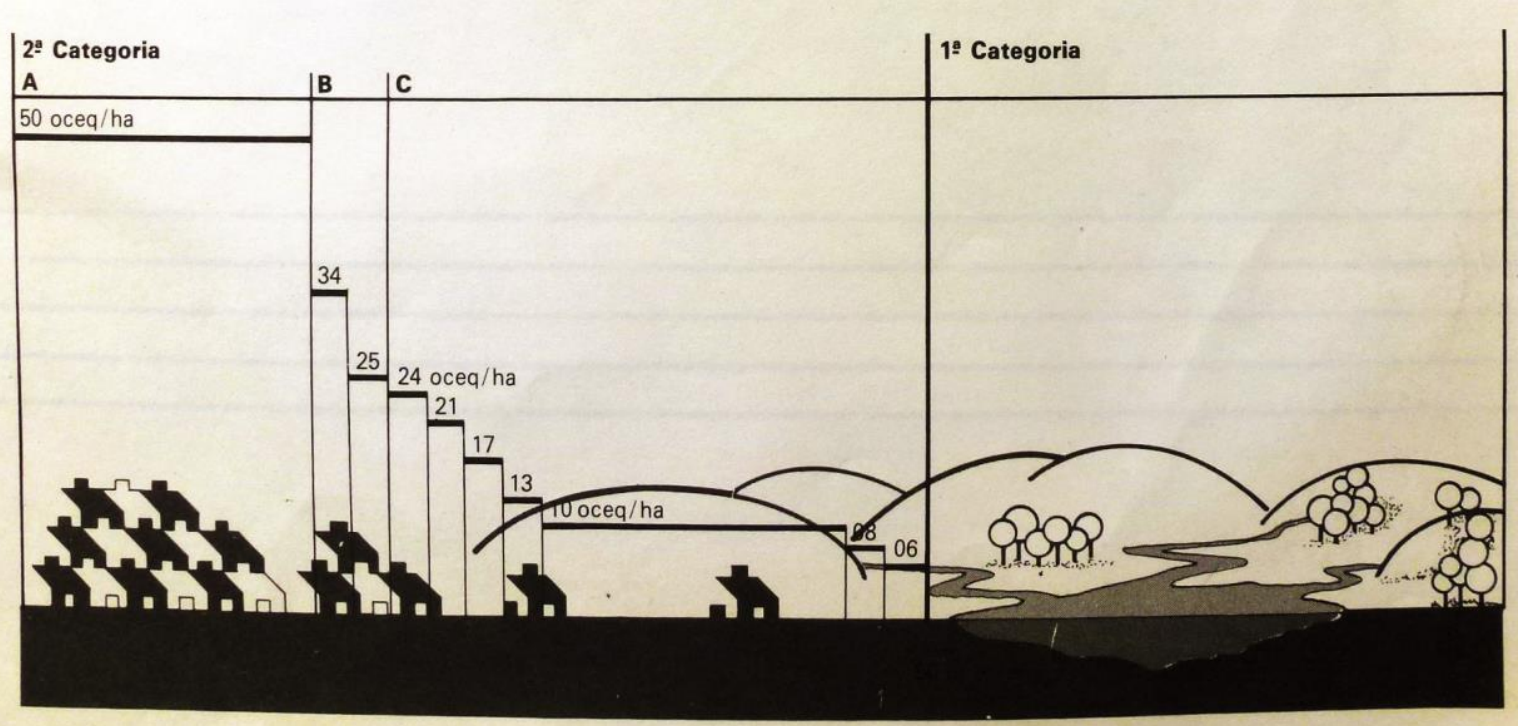

Figura 4).

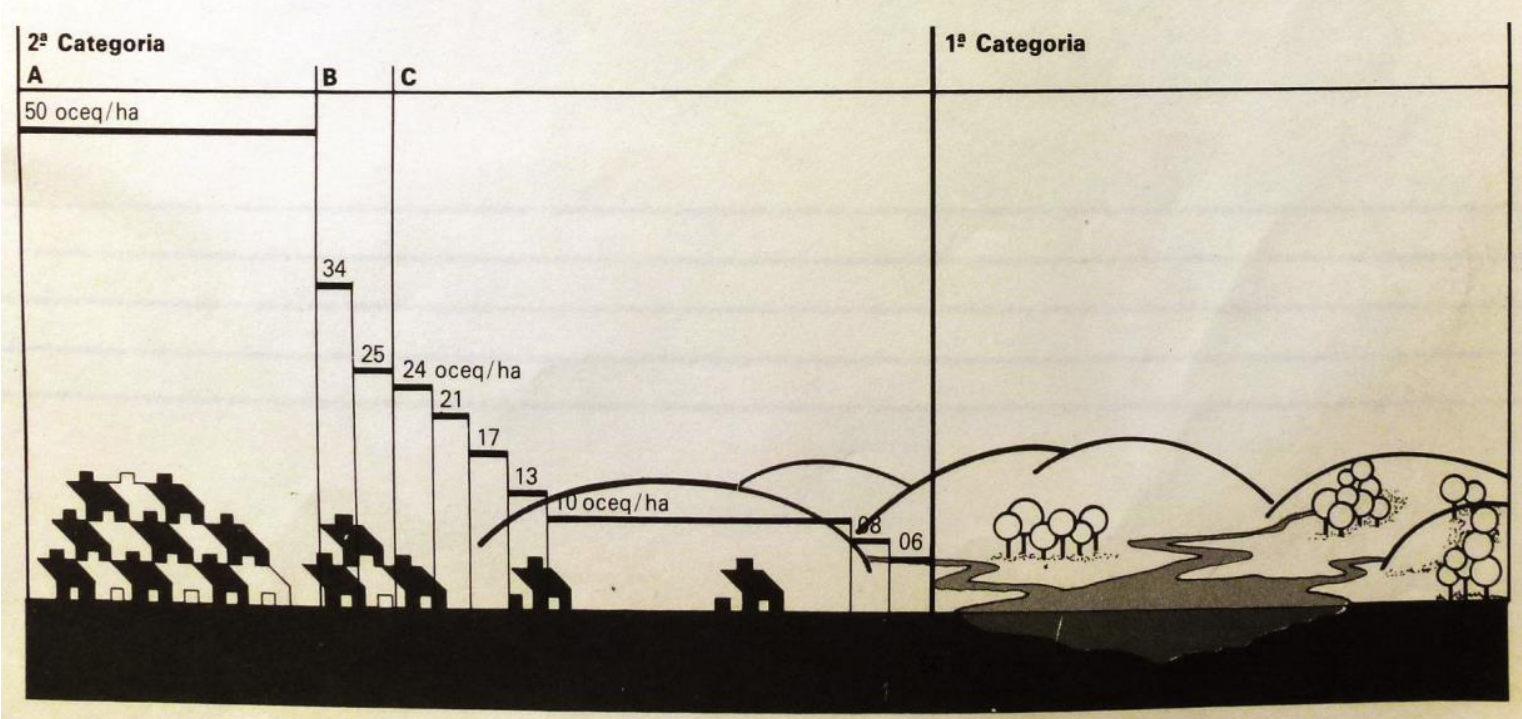

Figura 4 - Perspectiva esquemática sobre a aplicação da LPM - áreas de primeira e segunda categoria. Fonte: São Paulo, 1984. 
As críticas que se estabeleceram em relação a esse modelo legal são inúmeras, começando com o caráter preservacionista. Dentre elas, destaca-se principalmente: 1 - o descompasso da legislação em relação às dinâmicas de crescimento do território, uma vez que grande parte já estava sendo ocupado por parcelamentos do solo irregulares destinados à população de baixa renda, sendo a lei inclusive considerada como um ato de instituição da ilegalidade (MARTINS, 2006); 2 - o descompasso entre as instâncias estaduais e municipais na consecução dos objetivos propostos pela lei, deixando para medidas pontuais desconexas a tentativa de resolução do conflito; 3 - aspectos políticos-partidários nos desmandos da política pública, no caso, o clientelismo em larga escala, recaindo num discurso de uma fiscalização considerada ineficiente (SANTORO et al., 2008); 4 - alterações na dinâmica imobiliária, que desvalorizou o mercado formal de alta renda - pelas baixas densidades - e fortaleceu o mercado informal de baixa renda - preços baixos associados a falta de infraestrutura (SANTORO et al., 2008).

Contudo, a lei tinha um aspecto inovador: deflagrava o comprometimento da água para abastecimento público. No entanto, não se configurou como política pública eficiente, pois não contava com outros mecanismos para sua implementação; ela, isoladamente, era insuficiente para barrar a ocupação que caminhava a passos largos. O fato de ter sido gestada em anos de governo militar conferiu-lhe um caráter tecnocrático, sendo denominada como lei de comando e controle. Além disso, se seu objetivo era garantir a qualidade da água, sua origem foi tardia, visto que a represa já apresentava altos índices de poluição, sendo inclusive considerada pelos técnicos da Sabesp defensores do Sanegran como uma lagoa anaeróbica (Revista DAE 110, 1977). Agiu, ainda, na contramão de outras políticas: o descompasso com a realidade existente causou a imobilidade de políticas públicas habitacionais, ainda que pontuais, que esbarravam em suas restrições para uma ocupação planejada do território por outras esferas de governo.

De acordo com Meyer et al. (2003), a situação controversa - por um lado, a ausência de obras de melhorias amparadas por lei e, por outro, a qualidade da água que dependia inteiramente de ações públicas saneadoras e reparadoras - estendeu-se desde a década de 1970 até o fim dos anos 1990. Como exemplo, há o Projeto habitacional Chácara do Conde durante o período da gestão Erundina, no início da década de 1990, que mesmo diante de um longo processo de pactuação com movimentos de moradia e movimentos ambientalistas, não foi aprovado pelo órgão estadual competente (VILLAS-BOAS, 1995).

O período após a ditadura também fornece elementos para alterações na condução da política de recursos hídricos estadual, cuja legislação de 1991 é inovadora ao adotar a bacia hidrográfica como unidade de planejamento e gestão (UGRHI), além de instaurar mecanismos de participação através de 
comitês de bacia hidrográfica, órgão colegiado tripartite de caráter consultivo e deliberativo (IKEMATSU, 2014).

O novo quadro político e institucional brasileiro e a ineficiência do modelo legal que controversamente agravou a degradação da água, permitiu o aprimoramento de aspectos normativos de planejamento e gestão com novos atores em cena. Assumindo a pauta social e uma postura que buscou integrar os diversos setores e esferas de poder, pautado pela experiência de urbanização de favelas (SANTORO et al., 2008:108), o governo municipal, em articulação com esfera estadual - Secretaria do Meio Ambiente do Estado (SMA), Companhia de Saneamento Básico de São Paulo (Sabesp), Companhia de Desenvolvimento Habitacional e Urbano (CDHU), Prefeitura Municipal de São Paulo (PMSP) - constitui o grupo SOS Mananciais em 1991, tendo fundamentalmente ações de fiscalização, proteção e recuperação dos mananciais como premissas.

A experiência do arranjo institucional intersetorial, alguns anos mais tarde, em 1993, engendrou o Programa Guarapiranga - Programa de Saneamento Ambiental da Bacia do Guarapiranga contando com recursos do Banco Mundial (MEYER et al., 2003:96). Assumido pela estrutura do governo estadual, o objetivo principal era evitar a degradação dos mananciais, com ações de saneamento, coleta de resíduos sólidos, além de qualificação urbana com equipamentos, praças e espaços de lazer. No início da década de 2000, o Programa Guarapiranga foi ampliado para a bacia hidrográfica da Billings, passando a ser denominado Programa Mananciais. Essa alteração ampliava não só territorialmente a área, como também envolveu recursos federais na sua execução $0^{25}$.

O Programa Mananciais surge de modo claro, com objetivos de preservação da qualidade dos recursos hídricos a partir fundamentalmente da intervenção nos assentamentos precários, dotando-os com infraestrutura de saneamento. ${ }^{26}$ É preciso esclarecer que tratarei sobre o Programa Mananciais no

\footnotetext{
${ }^{25}$ Não é o foco do trabalho a discussão entorno da origem do Programa Guarapiranga mas sua importância como ação pública concreta na região dos mananciais que dá início ao Programa Mananciais ao qual o Cantinho do Céu está inserido. 0 que se verificou é que na gestão Erundina há o engendramento de uma postura que buscou integrar os diversos setores e esferas de poder buscando ações concretas de urbanização e recuperação ambiental dos loteamentos precários através de ações da SEHAB em Programas de urbanização de favelas (SANTORO et al., 2008:108). Mas somente com os recursos ampliados do Banco Mundial em 1996 essa ação pública se configura numa perspectiva mais ampla, onde os resultados dessas ações são mais efetivas. Para 0 montante de recursos, consultar Filardo (2004:277). Consultar a tese de doutorado da coordenadora do Programa Guarapiranga pela SEHAB/PMSP nos anos (1993-2000) para aprofundamentos sobre os projetos realizados no âmbito deste (FRANÇA, 2009).
}

${ }^{26}$ Os objetivos do Programa Mananciais correspondem a (1) recuperar e conservar a qualidade das águas dos reservatórios Guarapiranga e Billings; (2) melhorar as condições de vida dos moradores; (3) garantir a inclusão social da população e a sustentabilidade das intervenções urbanísticas realizadas pelo Programa, que transforma áreas degradadas em bairros. Através das seguintes ações: (1) implantação de redes de água e de coleta de esgoto; (2) drenagem de águas pluviais e de córregos; (3) coleta de lixo; (4) melhorias viárias para veículos e pedestres, com pavimentação e abertura de ruas e vielas; (5) eliminação de áreas de risco; (6) iluminação pública; (7) criação de áreas de lazer e centros comunitários; (8) re-assentamento de famílias; (9) construção de unidades habitacionais; (10) acompanhamento social junto à população moradora do local; (11) educação ambiental; (12) regularização fundiária mediante aprovação das Leis Específicas de Proteção e Recuperação dos Mananciais Guarapiranga e 
âmbito da Prefeitura de São Paulo, gerido por SEHAB. Este Programa, formalmente denominado como "Programa Saneamento, Proteção Ambiental e Recuperação da Qualidade das Águas em Áreas Degradadas de Manancial Hídrico" pela PMSP, integra o Programa Mananciais da antiga Secretaria de Saneamento e Energia (SSE), hoje Secretaria de Saneamento e Recursos Hídricos (SSRH), ${ }^{27}$ do Governo Estadual, do qual participam outras prefeituras da RMSP, como São Bernardo do Campo e Guarulhos e cuja denominação formal é "Projeto de Saneamento Ambiental dos Mananciais do Alto Tietê", com obtenção de recursos financeiros do Banco Mundial a partir de $2010^{28}$.

O aparato legal também vai se atualizar com a promulgação da Lei Estadual n. 9.866/97, a Lei de Proteção e Recuperação dos Mananciais (LPRM), que tem o objetivo não somente de proteção, mas de recuperação ambiental da bacia hidrográfica através de mecanismos descentralizadores de gestão, de forma participativa e integradora (esferas municipais, estaduais e sociedade civil organizada), fortemente influenciada pela Política Estadual de Recursos Hídricos (Lei Estadual nº. 7.333/91).

É importante lembrar que, mesmo que a legislação incorpore mecanismos de gestão num modelo integrado, a sobreposição de usos, ou seja, funções de abastecimento, geração de energia associados aos mananciais continua existindo. A sobreposição não impacta apenas nas sub-bacias às quais estão contidos os mananciais, mas, também, à bacia hidrográfica da Baixada Santista (UGRHI 7), e às sub-bacias à jusante e à montante (Alto Tietê - UGRHI 6 e Médio Tietê - UGRHI 10), já que os sistemas estão conectados, seja pelo mecanismo de drenagem natural da bacia hidrográfica, seja pelas obras de engenharia realizados nesse período, conforme descritos anteriormente. Segundo Carlos Eduardo G. Rocha, geógrafo da EMAE, atualmente as águas que vertem para a Baixada Santista também são utilizadas para abastecimento público de uma parcela do município de Cubatão, além da geração de energia (SMA, 2010:58).

Se por um lado a norma instaurava uma nova perspectiva de planejamento para o manancial, tais como, estudos e aprofundamentos da situação existente, além de mecanismos de recuperação e preservação através do Plano de Desenvolvimento e Proteção Ambiental (PDPA) com a elaboração de leis específicas para a definição de Áreas de Proteção e Recuperação de Mananciais (APRM) de cada bacia hidrográfica utilizada para abastecimento público. Por outro lado, em seus dispositivos finais, a

Billings. De acordo com informações encontradas no site da SEHAB/PMSP. Disponíveis em http://www.prefeitura.sp.gov.br/cidade/secretarias/habitacao/programas/index.php?p=3377. Acesso em 14 jan 2015.

27 Decreto Estadual $n^{0} .56 .635 / 2011$.

28 Informação disponível no site da SSRH: www.saneamento.sp.gov.br/cariboost_files/programamananciaissntese240311.pdf. Acesso em 14 jan 2015. Para análise e discussão acerca de tais programas, consultar Ferrara (2013). 
LPRM abria a possibilidade de ação concreta imediata com "obras emergenciais de abastecimento de água, esgotamento sanitário, drenagem de águas pluviais, contenção de erosão, estabilização de taludes, fornecimento de energia elétrica, controle da poluição das águas e revegetação29" constantes em Plano Emergencial a ser aprovado 120 dias após a promulgação da nova lei. O Decreto Estadual no. 43.022/1998 regulamentaria o Plano Emergencial, instrumento pelo qual os municípios poderiam atuar de modo corretivo nas áreas indicadas ${ }^{30}$. Entretanto, tal decreto permitia apenas a execução das obras, não contemplando procedimentos para a regularização fundiária destes assentamentos, tais como aprovação nos órgãos competentes de parcelamento do solo com vistas à individualização dos lotes - sendo esse mecanismo possível apenas a partir das leis específicas de cada manancial. Esses impasses legais, atrelados a outros elementos de ordem política (negociação com a Promotoria e Poder Judiciário), como veremos adiante, incidirão no adiamento da resolução dos problemas urbanos e fundiários do caso em estudo.

A primeira lei específica na Bacia Hidrográfica do Alto Tietê correspondeu ao manancial da represa Guarapiranga, Lei nº 12.233/06 - que define a Área de Proteção e Recuperação dos Mananciais da Bacia Hidrográfica do Reservatório Guarapiranga (APRM-G). Em 2009, seria aprovada a lei da Billings, Lei no. 13.579/09 - que define a Área de Proteção e Recuperação dos Mananciais da Bacia Hidrográfica do Reservatório Billings (APRM-B). No caso da lei específica da Billings, conforme mapeamento realizado anexo à lei, para as áreas já ocupadas e sem infraestrutura adequada é previsto o Programa de Recuperação de Interesse Social (PRIS), que corresponde a um conjunto de medidas e intervenções voltadas para a recuperação ambiental e regularização fundiária dos assentamentos irregulares desprovidos de infraestrutura, ocupados por população de baixa renda e localizados em Áreas de Recuperação Ambiental (ARA) ${ }^{31}$.

Esse período, entre a LPRM até a elaboração da lei específica da Billings se configura notadamente de transição. Segundo Ancona (2002:297), com a Constituição Federal de 1988, o Ministério Público intensificou a ação de exigência do cumprimento da legislação ambiental, gerando uma situação confusa do ponto de vista legal, uma vez que até a elaboração das leis

\footnotetext{
${ }^{29}$ Art. 47 da Lei Estadual 9866/1997.

30 Segundo noticiado em 06/10/98 pelo jornal O Estado de São Paulo, Caderno Cidades, foram delimitados 313 perímetros de obras nessa ocasião. Segundo relatado por Ancona (2002:308), a medida foi considerada eleitoreira por ambientalistas e outros setores organizados da sociedade já que coincidiu com período de campanha para governador.

31 O Decreto Estadual $n^{\circ}$ 55.342/2010 regulamenta os dispositivos da lei específica e a Resolução SMA nº. 25, de 10 de abril de 2013 disciplina o procedimento do enquadramento e licenciamento dos PRIS.
} 
específicas, a LPM continuava em vigor, causando ameaças pelas ações de desocupação. Segundo Santoro et al. (2009:115), a política pública desse momento configura-se totalmente atrelada aos processos judiciais em curso. O Plano Emergencial da LPRM seria resultado do tensionamento causado pelo Ministério Público para resolução dos casos urgentes em situação de risco. E é nesse momento que o projeto para o Cantinho do Céu começa a ser estudado. Sob a égide da Nova Legislação estadual de recuperação e proteção dos mananciais, e no bojo do Plano Emergencial, é que os estudos de urbanização e saneamento tem início. O perímetro do Complexo Cantinho do Céu, que envolve os bairros Cantinho do Céu, Parque Residencial dos Lagos e Jd. Gaivotas é definido nesse momento, pressionado pelo Poder Judiciário como será aprofundado no item seguinte.

\subsection{De um Cantinho PRivilegiado e protegido pela lei ao Complexo Cantinho do Céu}

Uma carta anônima ${ }^{32}$ enviada para a Promotoria em julho de 1994 inicia o envolvimento do Ministério Público com o que estava acontecendo de maneira clandestina no bairro e que três anos mais tarde seria denominado na Ação Civil Pública (ACP) relativa ao Cantinho do Céu como a “expressão viva do inferno de Dante", na expressão do Promotor Carlos Alberto Amin Filho, autor da ACP. Esta ação, movida pela Promotoria de Justiça de Habitação e Urbanismo da Capital em fevereiro de 1997 contra a Prefeitura, Governo do Estado e os ex-administradores regionais da Capela do Socorro da gestão Erundina (1989-1992) e da gestão Maluf (1993-1996) ${ }^{33}$, resulta de processo investigativo que envolveu não apenas o Cantinho do Céu, mas outros bairros que estavam passando pelo mesmo processo de ocupação ilegal.

O tom da carta era de denúncia, não apenas em relação ao processo de ocupação clandestina, mas, principalmente, pelo fato dos processos vigentes no bairro representarem além da desvalorização imobiliária do patrimônio dos moradores da região que eram "proprietários 'legítimos' (com escrituras registradas)", a desconfiguração do isolamento em relação ao urbano, numa "condição privilegiada e protegida pela lei". Convém destacar que o direito de propriedade

\footnotetext{
32 Ver Apêndice 2 onde há a sistematização de pontos de destaque do processo judicial da ACP.

${ }^{33}$ A organização administrativa da Prefeitura até o ano de 2002 era composta pelas Administrações Regionais, correspondendo hoje às Subprefeituras. A reestruturação administrativa deu-se pelas Lei Municipal n 13.399/ 2002 e Decreto Municipal $n^{0}$ 42.237/ 2002. $\mathrm{O}$ administrador regional na gestão Erundina citado é Leonide Tatto, cujo processo de improbidade administrativa corre em paralelo à ACP. O administrador regional na gestão Maluf, Enoque Leocadio dos Santos, foi assassinado em fevereiro de 2004. Fonte: "Assessor de deputado é morto a tiros" Jornal O Estado de São Paulo, Caderno Cidades, 17 fev 2004.
} 
privada no Brasil tem raízes históricas, conforme bem demonstrou Rolnik (1997) ${ }^{34}$ e em que pese a ordem jurídica e legal, ainda dependemos de interpretações pessoais de quem aplica a legislação e fiscaliza o seu cumprimento ${ }^{35}$. Os conflitos enunciados envolvem, portanto, além da contraposição histórica enunciada anteriormente, ou seja, o direito ambiental e direito à moradia, também o direito de propriedade. E antes de adentrarmos na discussão local desses conflitos, vejamos as seguintes fotos históricas que representam a evolução da ocupação na região:

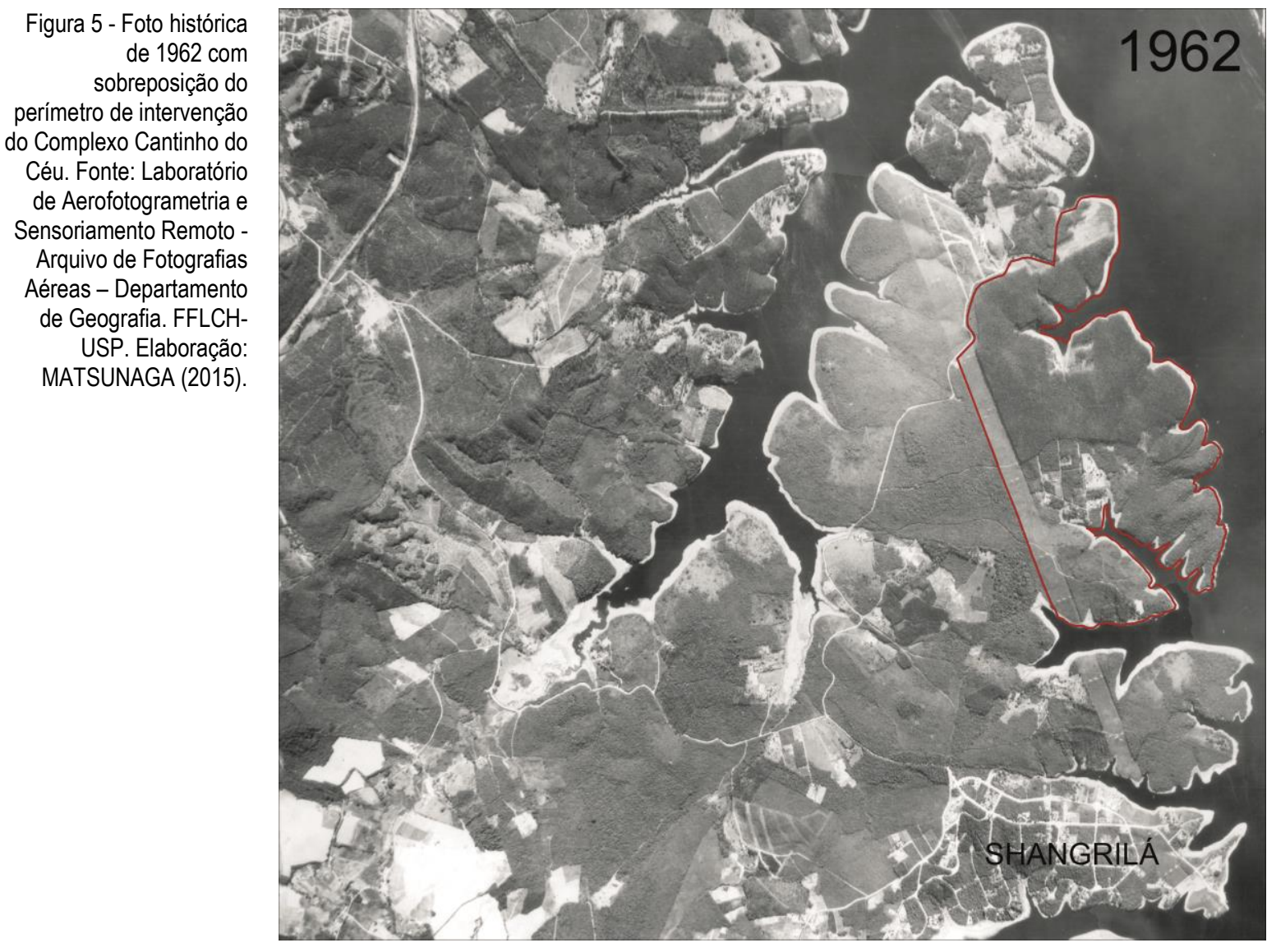

${ }^{34}$ Conforme Rolnik (1997) o direito de propriedade no Brasil é historicamente marcado pela disputa entre proprietários e possuidores (lei dos livros e a lei-em-ação) a partir da Lei de Terras de 1850 e cuja raiz histórica apresenta conflitos até hoje na esfera judicial sobre quem tem direito à terra.

35 Em depoimento a Polli (2010:173), José Carlos Freitas, atual promotor responsável pela ACP do Cantinho do Céu, constata que a formação e entendimento dos diversos magistrados envolvidos com os processos de reintegração de posse, loteamentos clandestinos é plural, não constituindo uma interpretação única da lei. 
Figura 6 - Foto histórica de $1972 \mathrm{com}$ sobreposição do perímetro de intervenção do Complexo Cantinho do

Céu. Fonte: Laboratório de Aerofotogrametria e

Sensoriamento Remoto Arquivo de Fotografias Aéreas - Departamento de Geografia. FFLCHUSP. Elaboração: MATSUNAGA (2015).

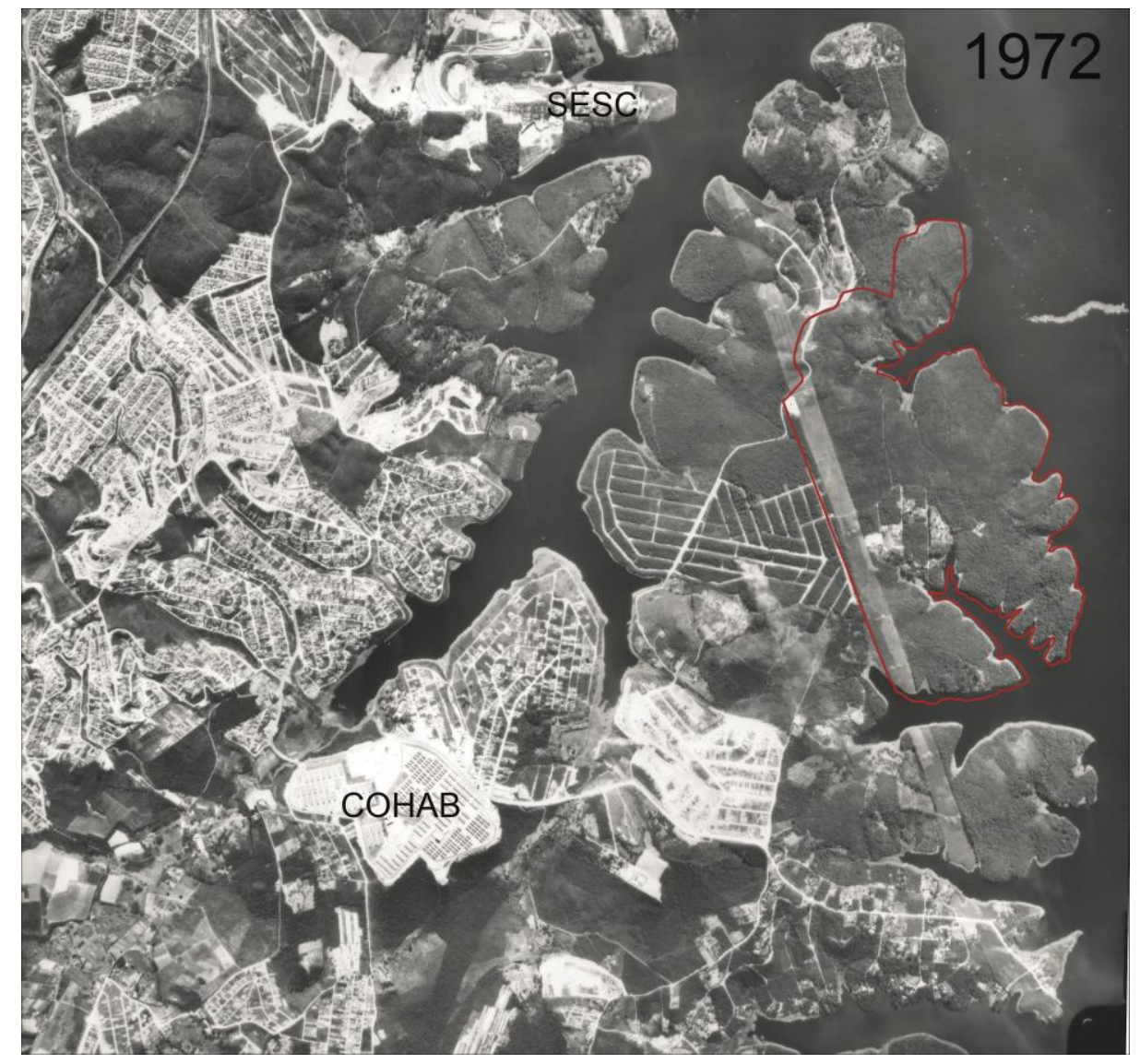



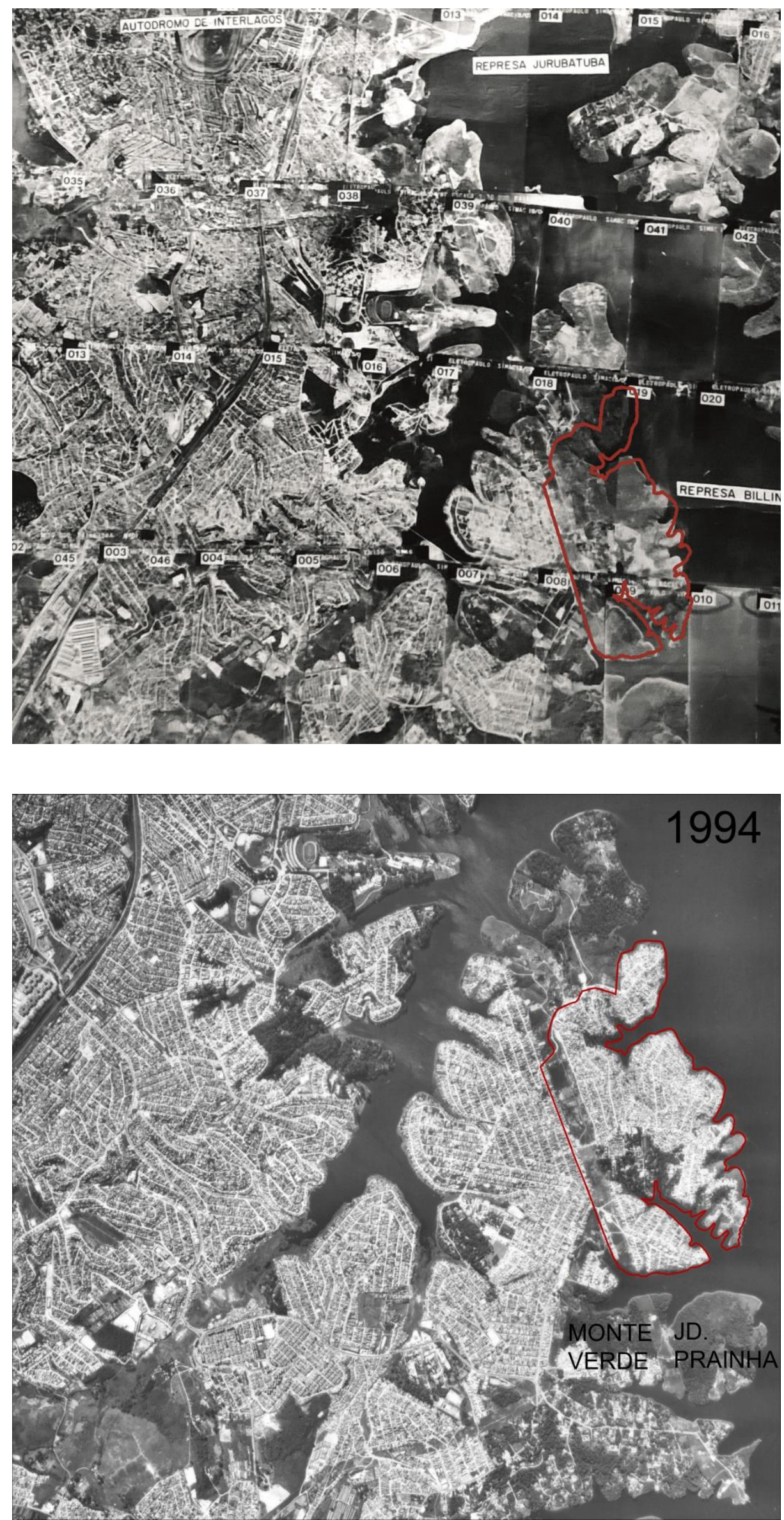

Figura 7 - Fotoíndice recobrimento aerofotogramétrico 1986-1989 -

Eletropaulo com sobreposição do perímetro de intervenção do Complexo Cantinho do Céu. Fonte: Laboratório de Aerofotogrametria e Sensoriamento Remoto - Arquivo de Fotografias Aéreas - Departamento de Geografia. FFLCHUSP. Elaboração: MATSUNAGA (2015).

Figura 8- Foto histórica de $1994 \mathrm{com}$ sobreposição do perímetro de intervenção do Complexo Cantinho do Céu. Fonte: Laboratório de Aerofotogrametria e Sensoriamento Remoto - Arquivo de Fotografias Aéreas - Departamento de Geografia. FFLCHUSP. Elaboração: MATSUNAGA (2015). 


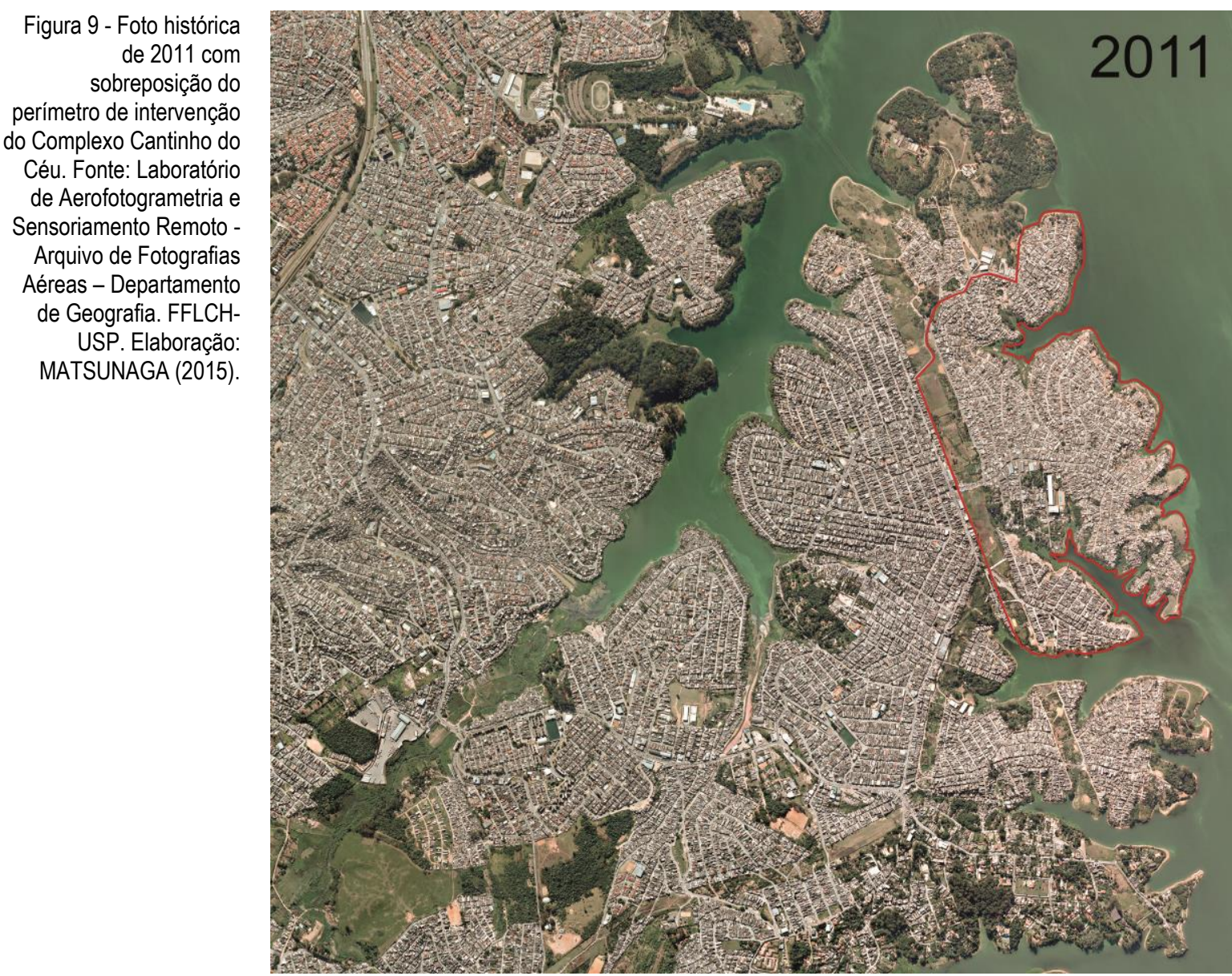

Em 1962 (Figura 5) predominavam grandes glebas de silvicultura, algumas chácaras e pouca remanescência de mata nativa. Nota-se o bairro de chácaras Shangrilá já parcelado, em sua península se localiza a Balsa do Bororé, ou 1ª . Balsa, permitindo o acesso à Ilha do Bororé. Até hoje, esse bairro pela presença da balsa se configura como ponto de lazer aos finais de semana.

A imagem de 1972 (Figura 6) já demonstra os parcelamentos com lotes menores. Obviamente, não é possível identificá-las como irregulares ou ilegais, apenas constatar que a mudança de uso começa a se constituir: as chácaras começam a coexistir com usos residenciais mais densos, notadamente de padrão popular, com lotes pequenos. Notam-se os surgimentos do Conjunto COHAB Faria Lima, mais conhecido com o BNH- Grajaú e, também, do SESC Interlagos.

A fotoíndice de 1986-1989 (Figura 7) demonstra a tendência do crescimento urbano em direção à península do Cocaia. Ressalta-se aqui um aspecto de sua condição físico-morfológica, caracterizando peculiarmente esses bairros localizados em sua porção leste e que, de alguma forma, pode ter auxiliado como freio da ocupação até fim dos anos 1980, enquanto a parte oeste da península teve ocupação anterior. Há uma extensa faixa non aedificandi, de aproximadamente 100m de largura, por onde passam quatro linhas de alta tensão de energia elétrica, agindo como uma barreira. 
A foto de 1994 (Figura 8) já mostra a ocupação quase total da região, permanecendo as glebas do Monte Verde e o Jd. Prainha. No entanto, alguns anos mais tarde esses bairros seriam formados, tendo ocupação percebida na foto de 2011 (Figura 9).

A condição configurada pelas linhas de alta tensão associada a questões geomorfológicas definirão os acessos aos bairros. Para cada um dos deles, o acesso é único e se dá pela linha de cumeada. Para chegar ao Jd. Gaivotas, utiliza-se a Estrada do Cocaia; para o Cantinho, a Rua Francisco Inácio Solano; para o Parque Residencial dos Lagos, a Rua Andorinhas Brasileiras, que bifurca formando um binário com a Rua Canário Belga (Figura 10); e para o Monte Verde e Jd. Prainha utiliza-se a Estrada da Ligação. Até hoje, em menor medida, a faixa de transmissão de energia elétrica se mantém como elemento na paisagem, configurando um elemento fronteiriço de acesso aos bairros. No caso do Cantinho do Céu, sua passagem guarda especificidades em relação aos outros bairros: há várias barraquinhas de frutas, CDSs, DVDs e espetinhos, marcando sua entrada.

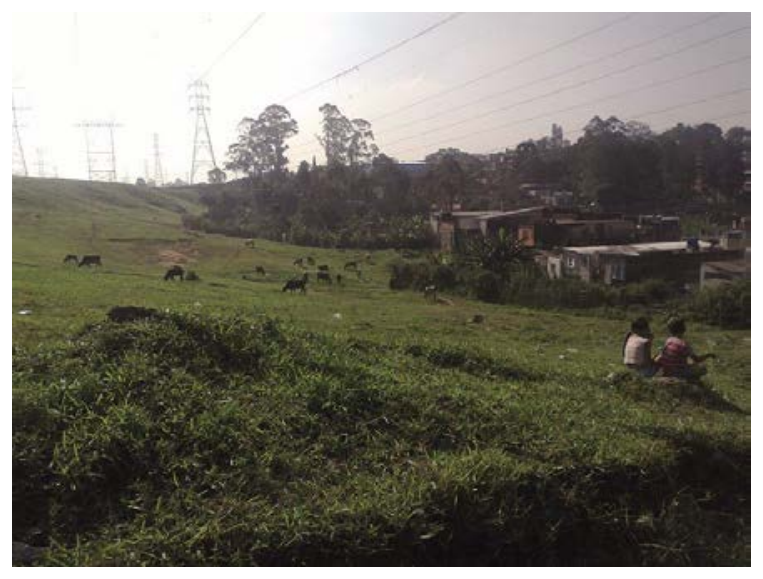

Figura 10 - Linhas de alta tensão no acesso ao bairro Parque Residencial dos Lagos. Crédito: Melissa Matsunaga, 2013.

Articulando, portanto, a evolução da ocupação territorial - percebida pelas imagens, numa tendência de espraiamento de ocupação urbana em direção às margens da represa - e as práticas denunciadas na carta anônima, elucida-se alguns dos conflitos fundiários e urbanísticos advindos desse encontro em disputa no território. Nesse sentido, de modo a focar o território do Complexo Cantinho do Céu, com base nas fotos aéreas, que registram a situação da ocupação na região nos anos indicados, buscou-se resgatar a evolução da ocupação das glebas cruzando, de forma aproximada, os domínios fundiários indicadas na Figura 11.

A venda de área para a linha de alta tensão à The São Paulo Tramway Light and Power Company Limited, em 1926, marca as transformações advindas pelo represamento do Rio Jurubatuba, também conhecido como Rio Grande, em 1927. As primeiras transcrições e registros cartorários presentes no processo judicial informam os proprietários das glebas, cujas respectivas áreas aqui sugeridas, formariam os bairros do Complexo, que pertenciam nesse momento a Francisco José Gomes 
e sua esposa, Felisbina Maria das Dores. A transferência à Light diz respeito a uma parte da gleba original, cabendo esta parte a área de $179.534 \mathrm{~m}^{2}$ ou 7,419 alqueires. No que se refere à gleba original, sua descrição consta a partir de elementos da natureza (Rio Jurubatuba, "caraguatá", "pau Couce de Vaca", "pau de Carvalho"), aspectos geomorfológicos ("espigão", "valeta"), ou confrontantes (Adolfo Antonio Domingues, Pereiras) como referências limítrofes e fora adquirida por Francisco José Gomes em 1908, ou seja, antes do represamento do Rio Jurubatuba, sendo, portanto, necessária a conjugação com outras fontes para sua delimitação precisa:

[...] principia no Rio Jurubatuba, nas divisas de Adolfo Antonio Domingues, segue por estas divisas demarcadas por um caraguatá, até enfrentar um espigão onde se acha uma valeta, desta à direita, linha reta, dividindo com Pereiras, a encontrar um pau denominado Couce de Vaca, junto ao qual se acha uma valeta, desta pelo mesmo rumo, dividindo com os mesmos, até um pau de Carvalho, nas divisas do adquirente, acompanha estas divisas até o Rio Jurubatuba pelo qual sobe até o ponto de partida ${ }^{36}$.

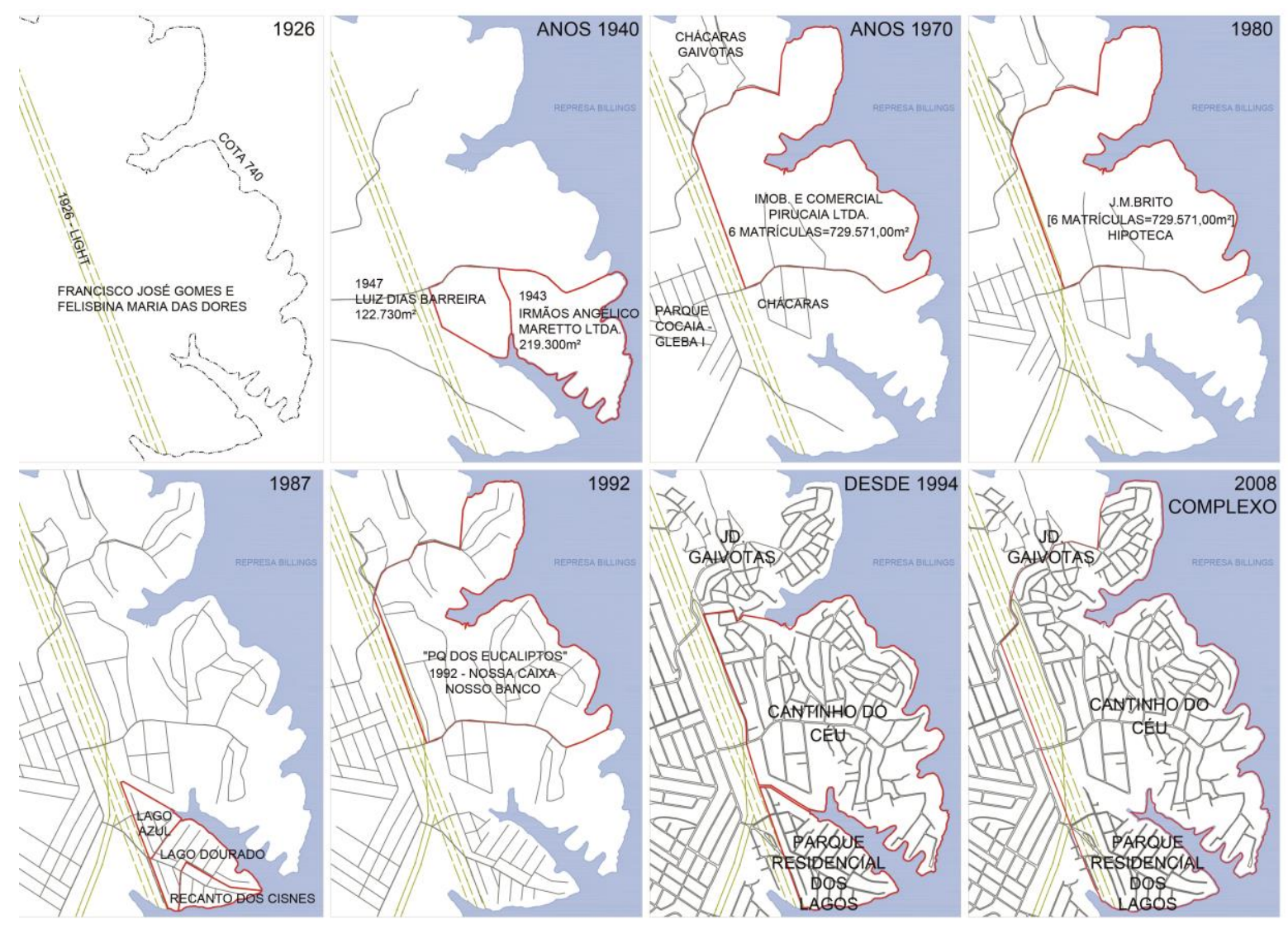

Figura 11 - Esquematização temporal dos domínios fundiários e evolução da ocupação. Fonte: Informações de fotos aéreas dos anos de 1962, 1972, 1994 (Laboratório de Aerofotogrametria e Sensoriamento Remoto - Arquivo de fotografias aéreas - Depto de Geografia/FFLCH-USP); Foto aérea de 1986: BASE Aerofotogrametria e Projetos, constante em Barda e França (2012:76); Matrículas $11^{\circ} \mathrm{CRI}$ constantes no processo judicial da ACP, volumes 2 e 18; Imagem de capa Revista VEJA SP de 19/06/1991 - ver Anexo 2. Base cartográfica: CESAD/USP. Elaboração: MATSUNAGA (2015).

${ }^{36}$ Fonte: Certidão 27.791 de 16/06/1995 do $1^{\circ}$. CRI da Capital, FI 406 e $407-2^{\circ}$ volume, processo judicial da ACP. 
No entanto, a conjugação aqui realizada é suficiente para demonstrar o processo de transformação do território: passando de grandes glebas, denominadas inicialmente sítios (Sítio dos Rodrigues, Sítio Batuíra), passando por chácaras, como foi o caso da gleba adquirida por Luiz Dias Barreira e esposa, Elisa Demarebi Barreira, que adquiriram 5 alqueires e $2.730 \mathrm{~m}^{2}$ em 1947, e que nos anos 1970 foi subdividida em chácaras. Grande parte dessas glebas foi destinada a silvicultura até o final dos anos 1980, quando estas começam então a serem parceladas clandestinamente para uso residencial, alterando a densidade da ocupação.

A atitude requerida pelo promotor autor da ACP, instaurada em fevereiro de 1997, dizia respeito à adequação do assentamento à legislação vigente. Na ocasião, a Lei de 1975/76 colocava outros parâmetros de urbanização para o parcelamento, sendo extremamente restritiva (lote mínimo de $5.000 \mathrm{~m}^{2}$ ) e segundo a qual o padrão já presente no bairro não era possível de ser aprovado (lotes existentes de $125 \mathrm{~m}^{2}$ ). O instrumento jurídico colocava também a adoção de medida liminar - chancelada pelo juiz em julho de 1997 - justificada pelo "imediato afastamento do risco à vida e à saúde incidente sobre os moradores e a população em geral", removendo famílias de "áreas de risco (onde os próprios moradores correm risco de vida) e área de primeira categoria (onde o dano ambiental e o envenenamento do manancial de água potencializa-se)". Diante dessa ameaça, configurou-se no bairro um movimento para não remoção das casas, cujo processo foi inclusive noticiado em jornais (Figura 12).

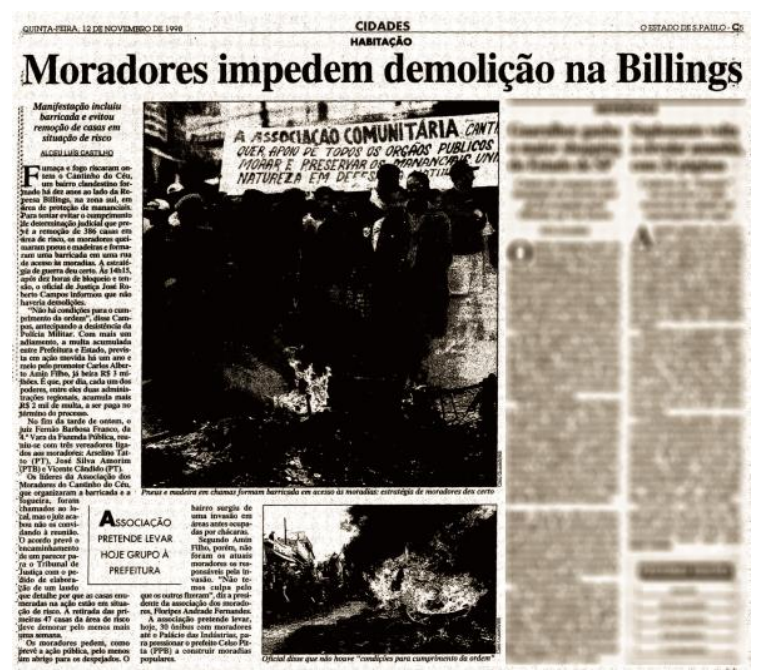

Figura 12 - Notícia do jornal "Moradores impedem demolição na Billings". Fonte: O Estado de São Paulo de 12 de novembro de 1998. Caderno Cidades.

Alguns meses apenas, após a ACP e sua medida cautelar, foi aprovada a Nova Legislação de Mananciais, estabelecendo, como já visto, uma nova perspectiva frente a esses assentamentos préexistentes, ou seja, era vislumbrada então a consolidação. Como a pauta era premente, inclusive sob pressão do MP, a nova lei estabelecia que os municípios poderiam agir "emergencialmente" com a definição de seus perímetros de intervenção, através do Plano Emergencial (Decreto Estadual nº. 43.022/1998). A inclusão no Plano Emergencial e a mobilização popular no bairro derrubariam a medida 
liminar no início de 1999, não incidindo em nenhuma remoção até que estudos mais aprofundados das áreas consideradas de risco fossem elaborados.

\subsection{Entre o Céu e a Água}

Não é interesse do trabalho a discussão do projeto urbanístico realizado do ponto de vista de seu resultado formal, ainda que expresse de maneira clara as diretrizes sob a qual o mesmo estava condicionado ${ }^{37}$. As diretrizes para o projeto, essas sim, interessam ao estudo, visto que representam o contexto histórico no qual ele se insere. Refaço o histórico de elaboração do projeto com o intuito de demonstrar que as obras em curso no bairro são resultados de uma longa negociação entre Prefeitura, Governo do Estado e Ministério Público. E não só isso, essa negociação, por sua vez, é marcada por um momento de transição de legislação e ideários que disputam um modelo de cidade contrapondo perspectivas ambientais que reiterou um modelo de desigualdade socioeconômica $\mathrm{x}$ função social da cidade e da propriedade no âmbito da política urbana. Como apontado na linha do tempo à página $37, \mathrm{o}$ que se busca, desde então, é uma "conciliação" entre meio ambiente e habitação. O Quadro 2 a seguir organiza fases sobre a elaboração do projeto e consecução das obras com os condicionantes legais ao qual esteve submetido ao longo do período:

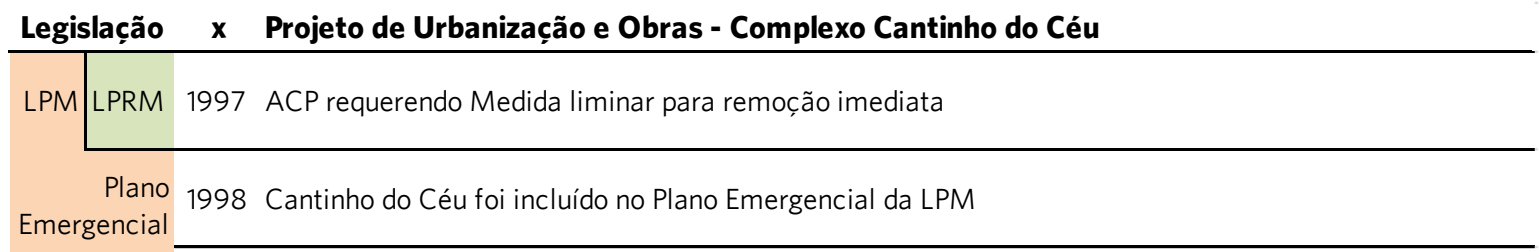

2000 Diagnóstico realizado por Marcos Carrilho Arquitetos (Fonte: BARDA \& FRANÇA, 2012:21)

2002 Relatório da SEHAB/PMSP

2007 Diagnóstico e Projeto Básico realizado pelo Consórcio JNS-Hagaplan - a partir do qual foi realizado o processo licitatório para execução das obras

-- Processo Licitatório - Lote 3 - Fase II do Programa Mananciais - Contrato 024/2008 SEHAB -

2008 Consórcio Schain-Carioca - Valor: R\$120.636.196,12 / Prazo: 48 meses (Fonte: Diário Oficial da Cidade de São Paulo - 04/06/2008)

2009 Projeto Executivo de Urbanismo e Paisagismo realizado pelo escritório Boldarini Arquitetura e Urbanismo

Lei -- Processo Licitatório - Lote 7 - Fase III do Programa Mananciais - Contrato 027/2012 SEHAB -

Específica 2012 Consório Recuperação Ambiental (Construbase-Engeform) - Valor R\$ 395.771.907,60 / Prazo: 36 da Billings meses (Fonte: Diário Oficial da Cidade de São Paulo - 08/11/2012)*

2013 Continuação das etapas seguintes do Projeto Executivo - escritório Boldarini Arquitetura e Urbanismo

Quadro 2 - Legislação incidente e Projeto de Urbanização e Obras no Complexo Cantinho do Céu.

${ }^{37}$ Alguns trabalhos abordam a experiência no âmbito do Programa Mananciais, como os de Alvim (2011) e Richards (2011). 
De acordo com as datas dos documentos analisados, temos em fevereiro de 1997 a instauração da ACP e, em maio de 1997, é expedida a medida liminar para retirada imediata de moradias em área de risco. Neste sentido, tanto Governo do Estado de São Paulo (GESP), como a Prefeitura, entram com recurso (Contestação por parte do GESP e Agravo de Instrumento por parte da PMSP) junto ao Poder Judiciário, argumentando sobre a necessidade de "estudos das condições de risco", "plano de demolição", e cuja articulação intersetorial era imprescindível para execução da liminar. Nesse meio tempo - de trâmite judicial - é aprovada a LPRM, em novembro de 1997, que como visto, abria a possibilidade de intervenção em assentamentos considerados emergenciais.

Segundo França (2012:21), o Cantinho do Céu foi incluído no Plano Emergencial por reivindicação das lideranças do bairro, Florípes do Cantinho do Céu e Emília do Jd. Gaivotas. Entendemos aqui, portanto, não apenas a pressão popular exercida, mas, também, a coação do Poder Judiciário na definição do Complexo e sua inserção no Plano Emergencial. Contudo, a perspectiva de consolidação representou um "adiamento" da urgência da resolução do risco anunciado, já que GESP e PMSP argumentavam obviamente a necessidade de elaboração de estudos e diagnósticos sobre a condição dos bairros. Em decorrência disso, em 1999, é derrubada a medida liminar que requeria a retirada imediata de moradias em condição de risco, paradoxalmente. Entretanto, mesmo com a flexibilização da ação cautelar, a negociação em torno da ACP permanecia, já que exigia, por parte do GESP e PMSP, a regularização da área conforme padrões estabelecidos na legislação vigente, e como anteriormente descrito, até que a lei específica fosse promulgada, a LPM continuava em vigor. Conforme afirmado por França (2012:21) no

[...] primeiro plano elaborado para o Cantinho do Céu, as soluções propostas ficavam condicionadas ao encaminhamento da Ação Pública e os projetos básicos deveriam servir como instrumentos de negociação da municipalidade. Assim, o plano urbanístico buscou preservar os lotes existentes - em sua grande maioria com cerca de $125 \mathrm{~m}^{2}$, articular um sistema de drenagem em fundos de vale, recuperando o papel depurador desses elementos naturais, eliminar situações de risco e implantar espaços públicos ao longo das margens da represa.

Um relatório completo é apresentado pela SEHAB em Audiência Pública com o Promotor Carlos Alberto Amin Filho em outubro de 2002, congregando atualização das moradias em situação de risco, estudos de viabilidade da urbanização conjugando orçamentos de cada um dos órgãos envolvidos. A partir de então, o que se percebe pelos autos do processo judicial é que o promotor que acompanha o caso é substituído em 2004 pelo Promotor José Carlos de Freitas, que 
passa a acompanhá-lo. Após recorrentes suspensões do andamento processual, somente em 2007, no âmbito do programa Mananciais, é que o processo e o projeto tem prosseguimento.

O Consórcio JNS-Hagaplan é contratado pela SEHAB para elaboração de diagnóstico e elaboração de Projeto Básico (PB), que seria submetido a processo licitatório para realização das obras $^{38}$. De acordo com o PB, eram previstas 2.483 remoções e 1.520 realocações, que consistem em remoção parcial do lote, sem a necessidade de remover a família da moradia. No $\mathrm{PB}$, além das remoções, eram previstas áreas para reassentamento da população removida. Porém, já era previsto que não eram suficientes para alocar o estimado da população. A melhoria do sistema viário foi enfatizado: foi previsto um sistema binário de entrada no bairro Cantinho do Céu, definindo a Rua Francisco Inácio Solano num sentido e outra via paralela noutro. Além disso, era prevista a interligação entre os bairros pela margem da represa através de um viário de borda (com exceção do bairro Lago Azul, devido à configuração de arruamento preexistente), possibilitado pelas remoções das moradias localizadas na margem. Não foi previsto, no entanto, nenhum local para implantação de equipamentos públicos de educação ou saúde, com exceção da enorme área destinada ao Parque Linear. Lembrando que o CEU Navegantes - único equipamento público até hoje - já havia sido construído e inaugurado em 2003.

Uma vez licitada a obra, em 2008, começou a ser implantado o Projeto Executivo (PE), realizado por Boldarini Arquitetura e Urbanismo, seguindo as diretrizes do PB. O escritório foi contratado pelo Consórcio Schain-Carioca, consórcio de empresas contratadas via licitação para realização do mesmo. O projeto foi vinculado ao ritmo das obras, sendo dividido em seis etapas (Figura 13).

Para cada uma das etapas foi realizado levantamento planialtimétrico que permitiu o aprofundamento das diretrizes estabelecidas no PB. As obras compreenderiam: complementação da rede de saneamento, que já estava sendo instalada pela SABESP; implantação de redes de drenagem de águas pluviais, em sistema de separação absoluto/total das redes da SABESP; implantação de pavimentação e consolidação geotécnica em alguns trechos. Foram revisados os perímetros de remoção definidos no $\mathrm{PB}$, tentando diminuir ao máximo o número de moradias a serem demolidas.

38 O Projeto Básico consta dos volumes 16 e 17 do processo da ACP. 
De acordo com a definição das etapas de obras, as remoções começaram pelo bairro Parque Residencial dos Lagos, ou Lago Azul. Concomitante ao projeto de urbanismo, o projeto de paisagismo seguiu a mesma organização sequencial (Figura 14). No caso da 1ª Etapa, correspondente ao bairro Parque Residencial dos Lagos, visto que a realização das remoções eram condição necessária não somente para a o parque, mas principalmente à necessidade de complementação das redes de infraestrutura de saneamento: a liberação da margem, por ser o nível altimétrico mais baixo, correspondia ao lugar da rede interceptora de saneamento. Convém destacar que, cada bairro, apresenta uma condição não apenas morfológica, todavia, de implantação prévia específica. Grande parte do arruamento já existente neste bairro convergia perpendicularmente à represa, instaurando projetos e soluções técnicas específicas para cada caso.

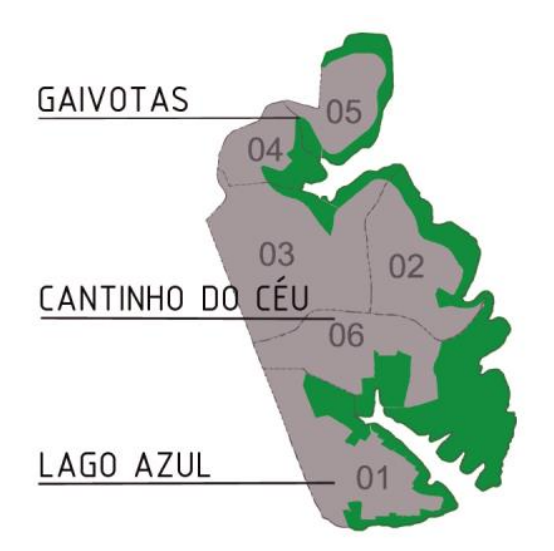

Figura 13 - Etapas do Projeto de Urbanismo do Complexo Cantinho do Céu. Fonte: Boldarini Arquitetura e Urbanismo

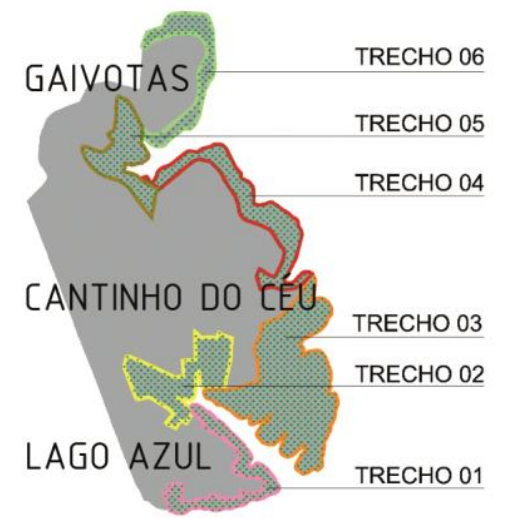

Figura 14 - Trechos do Projeto de Paisagismo (parque linear) do Complexo Cantinho do Céu. Fonte: Boldarini Arquitetura e Urbanismo

De modo geral, as remoções de moradias instaladas na borda da represa foram justificadas pela própria condição de inadequação de sua localização, incorrendo em risco geotécnico ou impossibilidade de coleta de esgotos (BARDA e FRANÇA, 2012). A proposta do projeto, negociada conjuntamente com o Ministério Público, trabalhou com a prerrogativa de que a consolidação de residências em alguns trechos de Área de Preservação Permanente (APP) - faixa de 50m a partir da cota de inundação da represa - poderia ser compensada ambientalmente com a recuperação e preservação de áreas contíguas de outros trechos (ALVIM, 2011). Ou seja, ainda que sob a égide da nova legislação de mananciais, o projeto não atrelou os preceitos da faixa de proteção de APP às remoções. Segundo Alvim (2011:9), sem a compensação ambiental, "inúmeras remoções seriam realizadas, descaracterizando completamente o bairro". Ainda em 2012 foi realizada outra licitação para continuidade das obras, consistindo na $3^{\text {a }}$ Fase do Programa Mananciais. No novo lote de 
obras (Lote 7) havia outros perímetros de intervenção incluídos, contemplando outros bairros da região, não se restringindo apenas ao perímetro do Cantinho do Céu.

Nesse caminho, podemos definir três momentos principais no histórico dos bairros. $\mathrm{O}$ primeiro - até o final dos anos 1980 - cujo uso predominante era de chácaras de lazer com a presença de grandes glebas destinadas a silvicultura. O segundo momento seria o início da venda dos lotes, no final dos anos 1980, instaurando-se a irregularidade urbanística, já que as medidas dos terrenos eram abaixo da permitida. A partir de então, através da atuação da Promotoria, instaura-se uma transição tensa, frente à remoção anunciada com mobilização da comunidade e visibilidade na mídia para os processos em curso. Podemos considerar que as disputas tratadas ao longo desse segundo momento foram decisivas no que aconteceria no bairro: a mudança de perspectiva da atuação do Estado em não mais remover e sim consolidar o assentamento diante da nova legislação. O terceiro momento seria a consolidação dos bairros através da adequação de infraestrutura de saneamento e regularização fundiária previstas na legislação estadual (ARA) e municipal (ZEIS 1). Como já visto, esse processo ainda não foi totalmente finalizado. Essa configuração em processo é o aspecto mais enfatizado no presente trabalho, uma vez que as entrevistas, abordadas na Parte II do trabalho, resgatam uma memória recente e principalmente o momento atual pelo qual o bairro passa. Como o Residencial dos Lagos consistiu na primeira etapa de obras, sua condição urbana hoje é bem diferente do que ocorre no Cantinho do Céu, cujo processo está em curso e onde predominam ainda incertezas sobre as áreas de remoção.

A experiência concretizada, uma das primeiras na área da sub-bacia da Billings, foi tida como modelo de intervenção pelo próprio executor, SEHAB/PMSP, que notadamente investiu em publicações, inclusive bilíngues, em relação ao trabalho desempenhado ${ }^{39}$. No entanto, o projeto do Complexo Cantinho do Céu não foi o único a ser propagandeado, sendo que grande parte das ações que SEHAB promoveu entre os anos 2005-2012 geraram publicações, exposições, concursos ou eventos (inclusive em solo estrangeiro) que envolviam, além de tudo, escritórios de arquitetura de projeção nacional, além de escritórios e universidades estrangeiras na cena em curso ${ }^{40}$.

\footnotetext{
39 Sobre o Cantinho do Céu há duas publicações oficiais pela SEHAB/PMSP: em 2009, "Operações Táticas na cidade informal Relatório do estúdio de investigação da Harvard Graduate School of Design e SEHAB", sobre estudos e propostas realizadas para o Núcleo Cantinho do Céu e, em 2012, "Entre o céu e a água", sobre o projeto e obra executados.

${ }^{40}$ As publicações podem ser encontradas na página da SEHAB: www.habisp.inf.br/doc/category/publicacoes. Acesso 14 jan 2015.
} 


\section{ÁREA EM TRANSFORMAÇÃO}

- Programa concebido no começo dos anos 1990 prevê urbanização de favelas, recuperação de mananciais e criação de parques

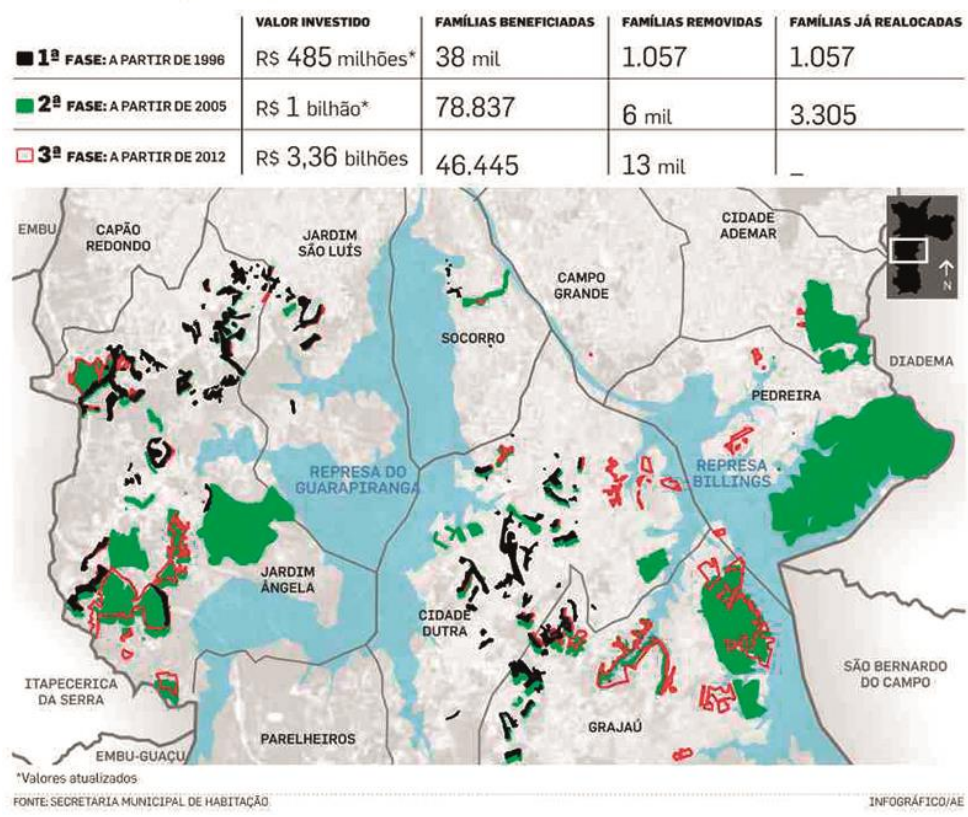

Figura 15 - Recursos investidos no Programa Mananciais. Fonte: Notícia "Kassab libera $\mathrm{R} \$ 3$ bi para reurbanizar 118 favelas e recuperar orla de represas", Jornal 0 Estado de São Paulo, Caderno Metrópole, 08 set 2012

No caso do Cantinho do Céu, a imagem propagandeada e seu uso político merecem destaque no âmbito das pesquisas acadêmicas e investigações posteriores podem aprofundar análises no assunto, correlacionando também o aporte de recursos financeiros - mais de 3 bilhões de reais para a $3^{\text {a }}$. Fase (Figura 15). 


\section{PARTE II - Os VIVENCIADORES}

O Complexo ${ }^{41}$ Cantinho do Céu localiza-se no Distrito do Grajaú, zona sul do município de São Paulo, às margens da Represa Billings. Dista cerca de $27 \mathrm{~km}$ do centro da cidade e seu principal acesso se dá pelas Av. Senador Teotônio Vilela e Av. Belmira Marin (antiga Estrada do Bororé). Dados do Censo 2010 do Instituto Brasileiro de Geografia e Estatística (IBGE) contabilizam 8.919 domicílios, perfazendo um total de 29.959 habitantes, correspondendo a 8\% da população calculada para o Distrito, que corresponde a 360.787 no mesmo ano ${ }^{42}$ (Ver Figura 16).

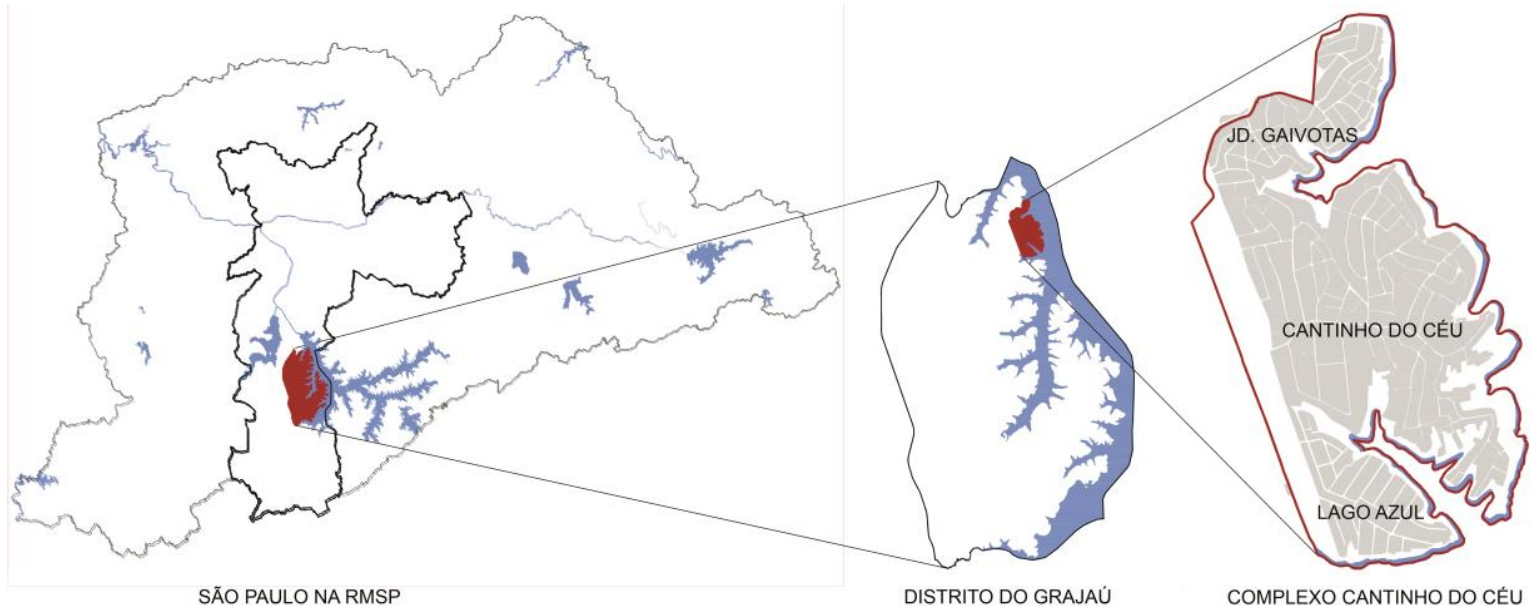

Figura 16- Localização do Complexo Cantinho do Céu. Sem escala. Base cartográfica: CESAD/FAUUSP. Elaboração: MATSUNAGA (2015).

${ }^{41}$ A SEHAB denominou Complexo Cantinho do Céu o perímetro de intervenção do projeto de urbanizado. Algumas vezes adotou 0 termo Núcleo Cantinho do Céu. Adoto ao longo da pesquisa: Complexo.

${ }^{42}$ Fonte: IBGE, Censo 2010. Informação disponível para consulta online em www.cens02010.ibge.gov.br/sinopseporsetores. Acesso em 02 dez 2014. 
Em relação ao município de São Paulo, o Distrito do Grajaú é um dos que apresenta maiores taxas de crescimento populacional entre os anos 1980-91, com 4,67\% em contraposição à taxa municipal de 1,16\% no mesmo período, mas, principalmente, entre os anos 1991-2000, com $6,22 \%$ enquanto o município apresenta o índice de apenas $0,88 \%{ }^{43}$ Como anteriormente descrito, o processo de crescimento populacional foi agravado pela restrição da LPM, inviabilizando o licenciamento de grande parte dos empreendimentos e favorecendo o parcelamento irregular.

$\mathrm{Na}$ parte leste da linha de transmissão da Eletropaulo, onde se localiza o Complexo Cantinho do Céu, predomina o índice de vulnerabilidade social alto e muito alto, segundo IPVS de $2010($ Ver

Figura 17), que conjuga, dentre outros indicadores sociais do IBGE, a classificação de aglomerados subnormais e renda média das mulheres responsáveis pelo domicílio. Percebe-se, assim, que em relação ao entorno, essa parte leste da linha de alta tensão se destaca não apenas pelo alto índice de vulnerabilidade, mas, principalmente, pela dimensão das manchas respectivas (de alta e muita alta vulnerabilidade social), demonstrando que uma grande parcela da população se encontra nessa condição.
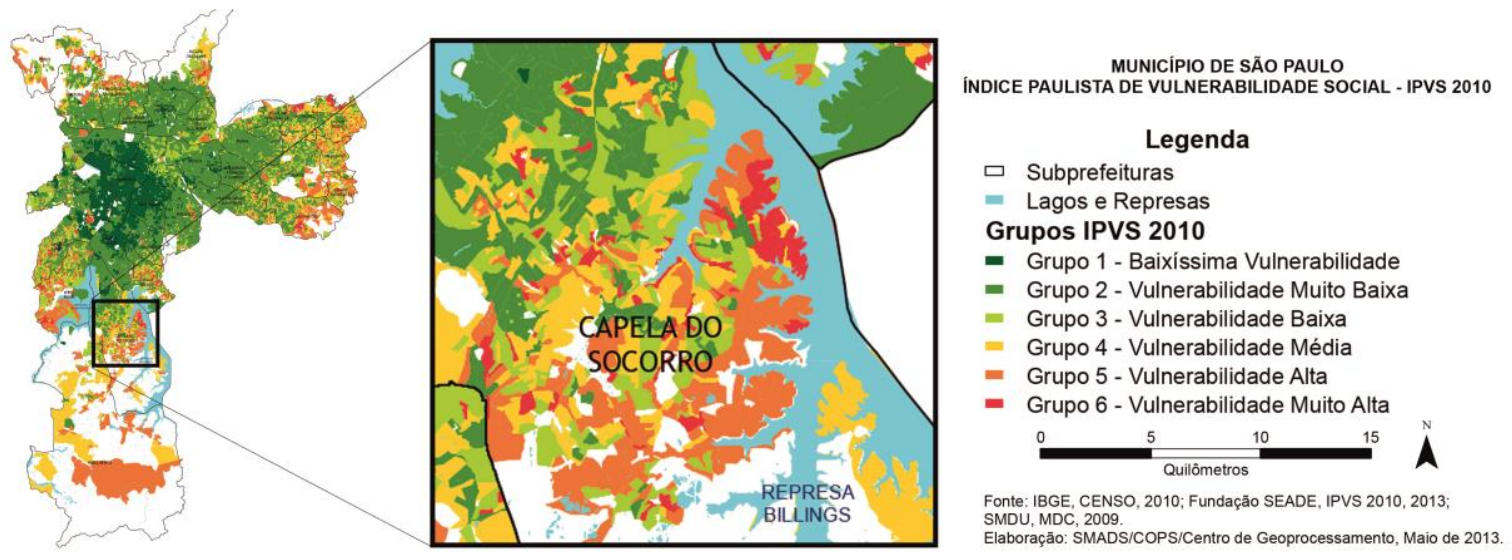

Figura 17 - Índice Paulista de Vulnerabilidade Social - IPVS 2010. Fonte: IBGE, CENSO 2010; Fundação SEADE, IPVS $2010,2013$. Organização: MATSUNAGA (2015).

No Complexo Cantinho do Céu, segundo dados da SEHAB/PMSP, as mulheres predominam como chefes de família, configurando $59 \%$ dos casos, contra $41 \%$ do sexo masculino. A renda média familiar é de $\mathrm{R} \$ 911,45$, sendo que $34 \%$ possuem carteira assinada, 16\% trabalham como autônomos, $6 \%$ com trabalhos eventuais, também entendidos como bicos, $5 \%$ são aposentados, $12 \%$ correspondem a donas de casa e 15\% encontram-se desempregados. A população infantil e jovem corresponde a 31\% até

${ }^{43}$ Fonte: IBGE - Censos Demográficos 1980, 1991, 2000 e 2010. 
14 anos e $21 \%$ entre 15 e 25 anos; a população considerada adulta - entre 26 e 59 anos - corresponde a 44\% e idosos configuram 4\%. ${ }^{44}$ Pelos dados, percebemos que há predominância de crianças e jovens, o que requisita a presença de equipamentos de educação e cultura. Ressalta-se que há uma altíssima taxa de desemprego (15\%).

Esta segunda parte do trabalho diz respeito ao meu encontro com alguns dos vivenciadores dos bairros Cantinho do Céu e Parque Residencial dos Lagos, integrantes do Complexo Cantinho do Céu. Com base nos depoimentos, dados primários e secundários, são elucidadas as representações e recursos mobilizados pelos vivenciadores em relação à transformação de sua paisagem. A organização é feita por dois capítulos. O primeiro trata da origem e constituição dos bairros, final dos anos 1980 e início dos anos 1990. As fontes secundárias e primárias ajudam a elucidar o momento histórico e político, procurando problematizar as representações acionadas nas entrevistas e conversas que versaram sobre a formação da irregularidade e os enfrentamentos da população com o Estado. O segundo capítulo aborda o momento atual dos bairros, num histórico recente em que a intervenção pública surtiu efeitos nas trajetórias dos vivenciadores entrevistados. Nesse caminho, as remoções e os deslocamentos causados constituíram o tema central do capítulo, abordando as estratégias de vida que os vivenciadores estabelecem diante das dificuldades e oportunidades que encontraram.

A Figura 18 indica os locais de moradia dos vivenciadores entrevistados, inclusive a indicação de ex-moradias de vivenciadores que tinham sido removidos até 2012. Destaquei, também, os perímetros de remoções já executadas e as previstas pela intervenção quando me inseri em campo, em janeiro de 2013.

É importante destacar que as entrevistas e conversas se dão influenciadas pelo status da intervenção no momento de realização da pesquisa de campo. As obras no Parque Residencial dos Lagos estavam em fase de conclusão, ou seja, as remoções já haviam acontecido, a infraestrutura de saneamento e, ainda, a drenagem e pavimentação já estavam instaladas. Restava apenas a finalização do parque no encontro com a Rua Garças Prateadas, que caminhou lentamente ao longo da pesquisa de campo. No Cantinho do Céu, as obras estavam paralisadas, sendo que as de urbanismo estavam em sua grande maioria finalizadas e os trechos sem infraestrutura correspondiam aos polígonos de remoção, cuja ação não tinha sido realizada (inclusive até o final da pesquisa de campo, outubro de 2014) com exceção da Rua Nossa Sra. De Fátima, indicado na Figura 18. No entanto, ainda faltavam remoções e,

\footnotetext{
${ }^{44}$ Fonte: Barda e França (2012:111). Os dados foram informados pela Cobrape, empresa responsável pelo gerenciamento social do
} Programa Mananciais em 2009. 
consequentemente, o parque (cujo projeto executivo só é realizado após as remoções e a partir de novo levantamento planialtimétrico). Deve-se considerar que o momento de inserção em campo coincidiu com a transição de governo municipal, após praticamente duas gestões sequenciadas pelo governo anterior, alterando profundamente os encaminhamentos de obras e projetos em curso.
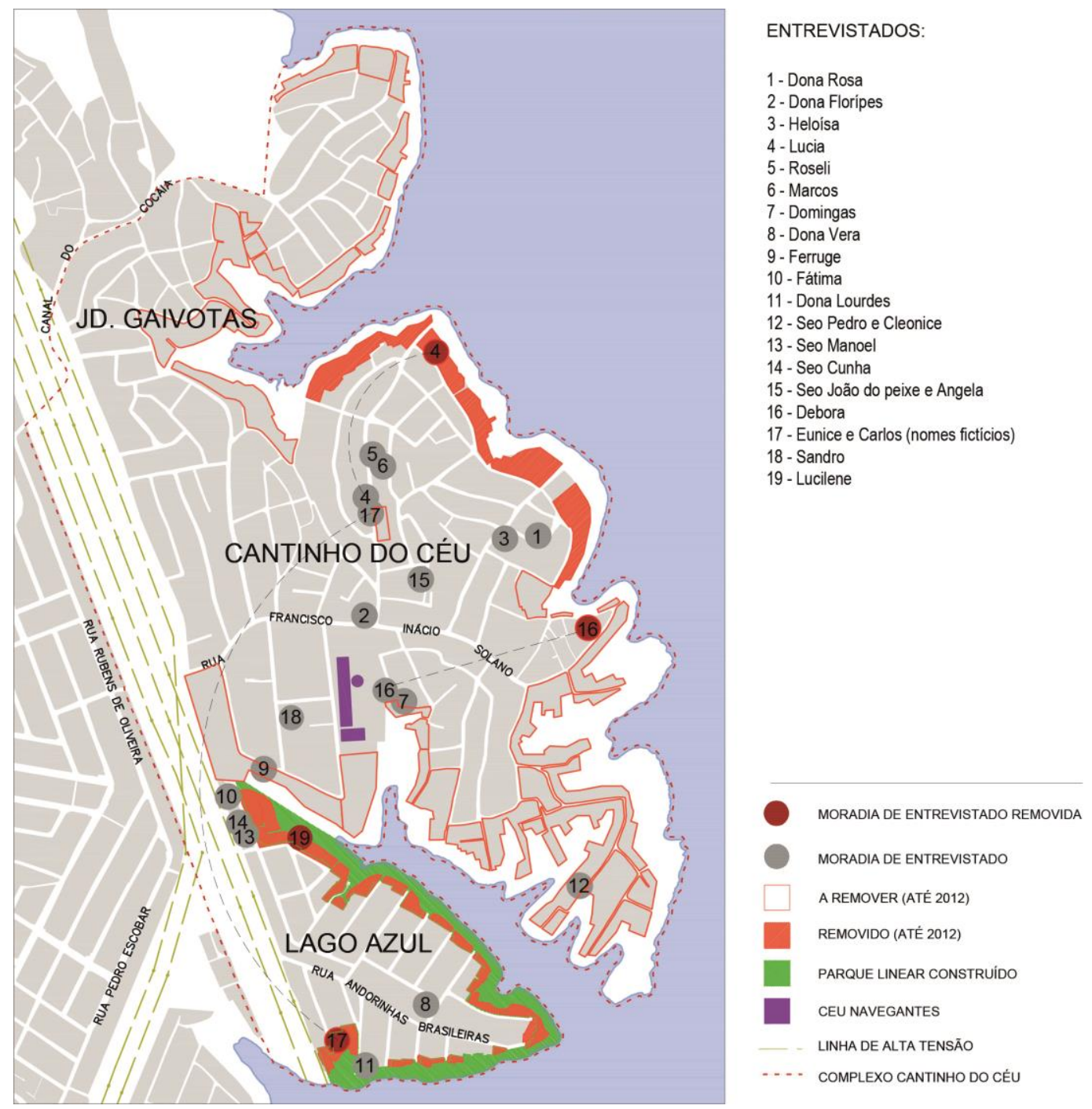

Figura 18 - Vivenciadores entrevistados e status das remoções no início da pesquisa de campo em janeiro de 2013. Fonte: Base cartográfica: CESAD/FAUUSP; Remoções: Barda e França, 2012. Elaboração: MATSUNAGA (2015).

É provável que se a pesquisa se desse num período posterior à intervenção, as representações poderiam não ser as mesmas. Segundo Halbwachs (1990), a elaboração das memórias, como reconstrução do passado, é fortemente influenciada pelo contexto em que elas se dão. Bosi (2004:414) torna múltiplo esse procedimento ao constatar que a interação social é fundamental para que as lembranças ganhem consistência, "é preciso estar sempre confrontando, comunicando e recebendo impressões". Nesse percurso, permanecem o tema e a abordagem em estudos que possam se desenvolver posteriormente. 


\section{CAPÍTULO 02}

\section{UM CANTINHO PARA CHAMAR DE MEU}

A toponímia que designa cada um dos bairros ajuda a construir o imaginário social de um lugar próximo à natureza, com a forte presença de elementos naturais, quase um paraíso: Gaivotas, Lagos, Céu. A presença de chácaras de recreio, originalmente na região, especificamente onde hoje se formou o bairro Cantinho do Céu, empresta o nome inclusive de uma delas. No bairro Residencial dos Lagos, segundo depoimento de Dona Lourdes, moradora antiga, a área correspondia à chácara de um japonês: "isso aqui tudo era de um japonês e ele plantava mandioca e criava porco. Aqui dizem que era uma criação de porco. (...) Dizem que morava aqui em cima. Tinha a casa que ele morava. E como a mandioca não estava dando ele colocou na imobiliária os lotes e vendeu tudinho isso aqui".

No entanto, é necessário dizer que a conjunção dos três bairros - ao ser tratado institucionalmente como um Complexo - externamente homogeneizou sua representação, sobrepujando o nome Cantinho do Céu em relação aos demais. A intensa divulgação da ação pública empreendida, em jornais, exposições e prêmios internacionais, que projetou externamente uma imagem positiva da intervenção, trouxe um discurso único de venda irregular de lotes, sem caracterizar devidamente as especificidades das origens de cada bairro (BARDA e FRANÇA, 2012; WERTHMANN, 2009). Ainda que haja similaridades de um padrão irregular precário, anular a origem dos bairros põe em comprometimento sua identidade, o sentimento dos moradores em relação à própria intervenção e, principalmente, o acirramento de processos de identificação entre os bairros.

Com o objetivo de elucidar essas diferenças, o presente capítulo trata sobre a constituição dos bairros Cantinho do Céu e Parque Residencial dos Lagos e se divide, portanto, em duas partes: a primeira trata sobre a formação do Cantinho do Céu, visto que a segunda, sobre o Parque Residencial dos Lagos. Como a abordagem do tema diz respeito a um passado que nem todos os vivenciadores presenciaram, nos dois bairros tentei realizar conversas coletivas com moradores antigos que partilhassem desse momento e pudessem elaborar, de modo conjunto, suas narrativas. Em adição ao tema, em entrevistas individuais com lideranças, também foi possível compor o período almejado. 
Assim, ao abordar o tema do histórico de ocupação dos bairros nas entrevistas realizadas, pude notar que a atuação das lideranças comunitárias foi essencial para a configuração urbana existente atualmente. Tanto o Cantinho do Céu quanto o Parque Residencial dos Lagos tem em seu histórico a luta pela moradia e o papel destacado das lideranças na obtenção das melhorias conquistadas, com diferenças cruciais no histórico dos conflitos e atuação do Estado frente aos mesmos. A origem dos bairros, dada à irregularidade, é tema que merece atenção e cuidado, ainda que os vivenciadores se permitam narrar os acontecimentos, percebi que algumas informações, por exemplo, as imobiliárias que atuaram e que atuam no Cantinho do Céu, especificamente, era um aspecto evitado: ou não lembravam o nome, não lembravam exatamente o nome da rua, ou o nome da pessoa; respeitei o pacto de silêncio. Em diferença com o Residencial dos Lagos, cujo processo foi enfaticamente descrito.

A figura a seguir (Figura 19) apresenta a rede de equipamentos públicos na região da península do Cocaia, alguns utilizados e evocados pelos vivenciadores entrevistados. As fronteiras entre os bairros não foram delimitadas exatamente porque representam tensões em relação ao território correspondente de cada um. A ocupação urbana é praticamente total da península, os limites entre os bairros não se configuram claramente, permitindo que a definição da fronteira seja dada pela condição morfológica, como no caso do Parque Residencial dos Lagos, que ocupa uma pequena península e seus limitantes são marcados por linhas de talvegue com o bairro Cantinho do Céu e com o bairro Jequirituba. No entanto, quando a condição física é semelhante, sem marcos de relevo como talvegues ou cumeadas, essa fronteira é de difícil definição, como ocorre entre o Cantinho do Céu e seu limite com o Jd. Gaivotas, que pela conurbação, essa linha de divisa, ainda que numa condição de talvegue, não é claramente percebida (os próprios moradores não sabem indicar exatamente as fronteiras entre os dois bairros, sendo que apenas uma moradora indicou a Rua Copacabana como elemento divisor). Estão indicadas, também, as alterações físicas realizadas pela intervenção em curso no perímetro do Complexo até 2012, tais como: indicação das remoções realizadas, área corresponde ao parque linear construído e localização de Estações Elevatórias de Esgoto (EEE) encontradas em campo. 


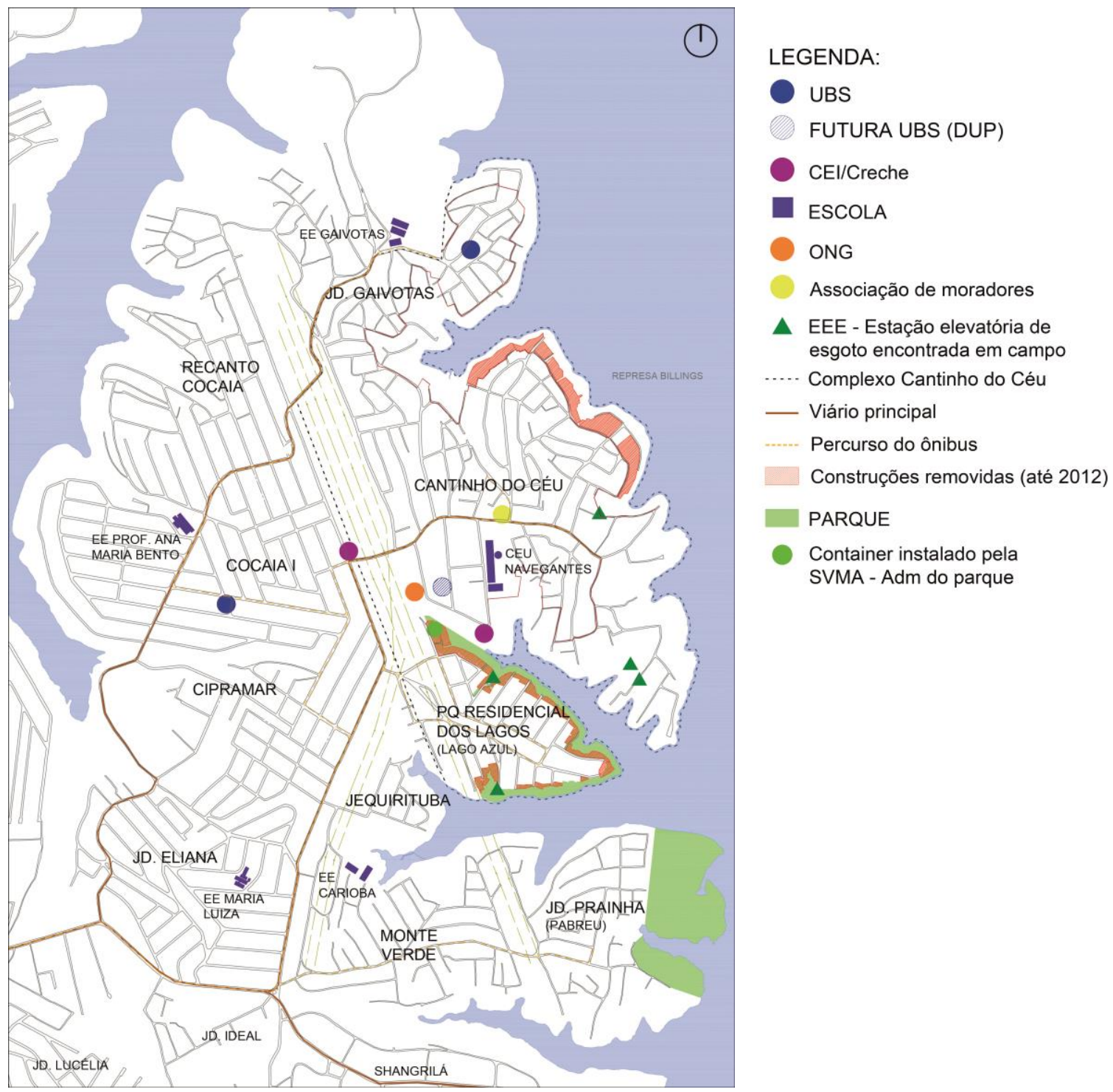

Figura 19 - Equipamentos e acessos principais aos bairros da Península do Cocaia. Base cartográfica: CESAD/FAUUSP. Elaboração: MATSUNAGA (2015).

\subsection{Num CANTINHO dO CÉU}

Em 1989 foi fundada a associação. Eu entrei como tesoureiro na associação nove anos atrás, acho que foi 2003 ou 2004. Eu via na televisão: favela Cantinho do Céu. E eu falava, eu não moro numa favela! Morava no Sumaré, mudei para morar numa chácara e agora fala que é favela, nunca foi favela! Entrei na associação para desvincular essa ideia.

"Vou falar a história verdadeira!" diz Sandro Mambelli, 56 anos, no início da nossa entrevista. Sandro, que é o atual presidente da Associação de Moradores do Cantinho do Céu, apresentou-se a mim como "contador de histórias", como se já quisesse me alertar para a sua versão dos fatos. Segundo Sandro, a região onde se localiza o bairro pertencia à antiga Fazenda Jequirituba, de propriedade de Antonio Dias Barreira, que fora parcelada em 22 chácaras de recreio 
escrituradas. O nome do bairro - Cantinho do Céu - remete ao nome da chácara comprada por seus pais, Pier e Antonia, em 1967:

Eles moravam no Sumaré, na Rua Amália de Noronha. Compraram em 1967 essa chácara para pagar em 100 meses e no início eles só vinham aos finais de semana aqui. Eles criavam vaca, cavalo e participavam de romarias. Como nossa família morava lá no Sumaré e começou uma violência, droga, muita bagunça naquela época, em 1969 vieram morar pra cá. Eu lembro, tinha 9 anos, aqui era o sonho, a gente fazia romaria de cavalo, procissão para uma Bom Jesus de Pirapora, então a gente rodava $80 \mathrm{Km}$ a cavalo. Vinham todas as turmas daqui que tinha cavalo, os donos de chácara tinham cavalo ali no Gaivotas. E tinha um conde lá que colecionava carros, então ele devia ter uns 50 carros antigos dentro dos galpões, Ford 29, Chevrolet, todos esses carrões. E quando começou essa invasão, então todo mundo fugiu daqui né. E nós ficamos.

O processo de ocupação irregular é claramente descrito por Sandro, já que impactou diretamente na produção de coelhos que a família mantinha:

Quando começou essa invasão eu fui um dos primeiros a ir contra. Eu não aceitei. Meus pais estavam vivos. Nós criávamos 1600 coelhos. Coelhos gigantes de Flandres, dava 7 ou $8 \mathrm{Kg}$, a gente matava, limpava, mandava o couro pro curtume e a carne a gente levava para os restaurantes. Aí quando começou isso aí, acabaram com todo o mato, você ia cortar capim, não tinha mais capim. A gente criava os coelhos na chácara, mas cortávamos o capim na beira da represa. Aí veio esse povão e acabou com tudo.

Hoje, a Chácara Cantinho do Céu é subdividida entre os três irmãos Mambelli, onde Sandro reside juntamente com sua esposa e filhos. Conta-me que cria cachorros e não mais coelhos, possuindo nove destes. Além da associação de moradores, Sandro também administra duas creches conveniadas com a prefeitura, a CEI Cantinho do Céu, com 132 crianças e a CEI Antonia Mambelli, no bairro Parque Residencial Cocaia, atendendo 195 crianças.

No caso do bairro Cantinho do Céu, podemos dizer que a ideia de um cantinho paradisíaco presente na toponímia remete ao primeiro momento do bairro. É interessante perceber como o nome atribuído simbolizava para os chacareiros esse isolamento num local intocado, sagrado, privilegiado e protegido pela lei. E como essa paisagem estava sendo ameaçada pelas "invasões":

Moramos há 25 anos em uma chácara de nossa propriedade às margens da represa Billings - mais exatamente no Cantinho do Céu - com toda documentação em ordem e de pleno acordo com a lei. Quando compramos a chácara, em 1973, a região era um paraíso ecológico com mata atlântica intocada. Enfrentamos grandes distâncias para chegar a padarias, farmácias, supermercados, açougues, em ruas de terra (hoje ziguezagueamos em ruas asfaltadas tentando contornar os buracos...). Não havia rede elétrica - nosso gerador forneceu a energia. Hoje pagamos altas contas de luz em troca de péssima qualidade, constantes interrupções de fornecimento, luz fraca e piscando - certamente em consequência das milhares de "gambiarras". Nosso poço 
forneceu água cristalina de excelente qualidade- até as invasões e o esgoto lançado a céu aberto provocaram a contaminação do lençol freático. Nos sujeitamos a todas essas dificuldades, foi a nossa opção de viver em plena harmonia com a natureza em busca de melhor qualidade de vida. ${ }^{45}$

O adensamento que colocou em ameaça o "paraíso ecológico" dos chacareiros é enunciado, principalmente pela mídia, que constrói a imagem do bairro como "favela" a ponto de Sandro, na condição de ser o proprietário da chácara que designa o bairro, combater a vinculação do lugar onde vive com o estigma socialmente construído: "eu não moro numa favela".

Como visto anteriormente, de acordo com matrículas anexadas aos autos do processo, o bairro Cantinho do Céu é formado por três glebas. A primeira dizia respeito à gleba parcelada em chácaras e que inicialmente seria a única com registros das chácaras em cartório (Ver Figura 20).

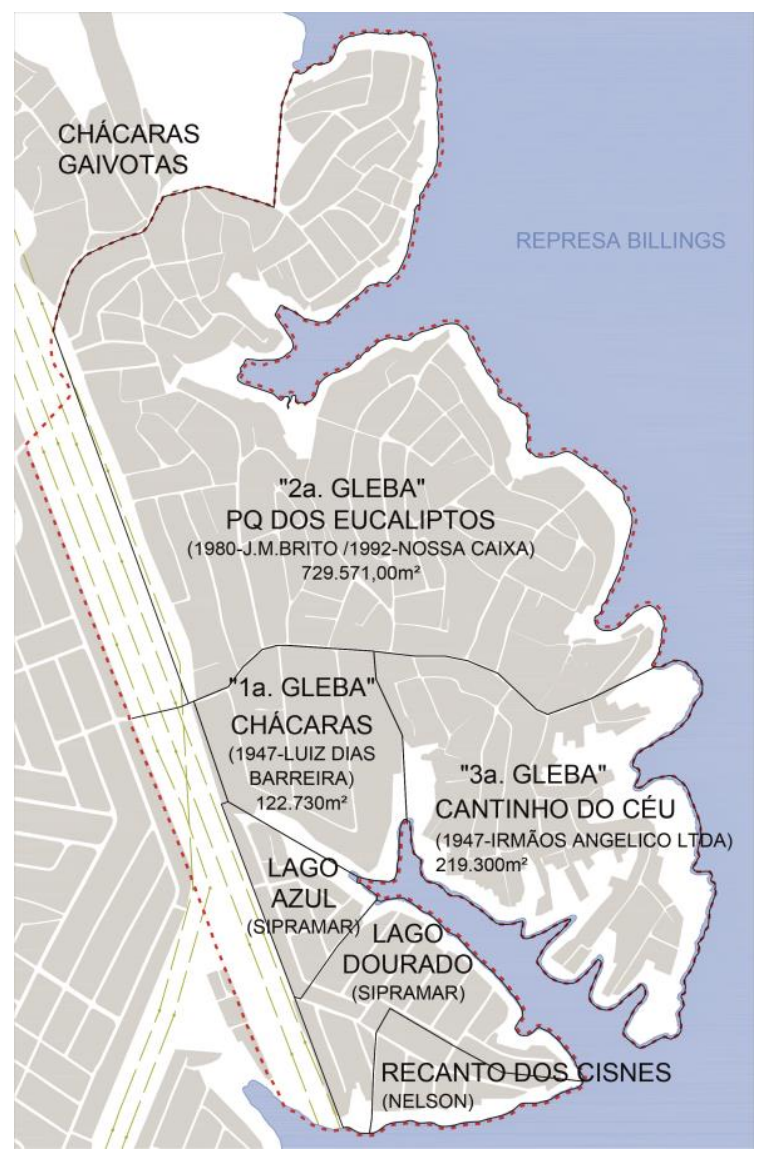

Figura 20 - Delimitação aproximada das glebas e domínios fundiários. FONTE: Cantinho do Céu: $18^{\circ}$ volume do Processo Judicial. Residencial dos Lagos: entrevistas e depoimentos. Base: CESAD/FAUUSP. Elaboração: MATSUNAGA (2015).

As chácaras do bairro foram, em sua maioria, descaracterizadas com o processo de adensamento populacional do Cantinho do Céu ocorrido no final dos anos 1980. Segundo informações da Promotoria, apoiada em denúncias e depoimentos colhidos na investigação judicial, o Cantinho do Céu teve ocupação e adensamento ilegal iniciada em 1989 através de venda

${ }^{45}$ Carta de Klaus e Barbara ao Promotor em novembro de 1998 - grifos do autor. Fonte: Processo judicial da ACP, fls 2422 a 2426 , vol 13. 
clandestina de lotes de glebas onde se cultivava eucaliptos e que "formaram um todo contínuo e de difícil identificação". Restam algumas: a chácara que batiza o bairro todo, de propriedade do atual presidente da Associação dos Moradores; a chácara onde estaria predestinada uma unidade de saúde; uma chácara utilizada para eventos como festas de casamento, aniversários e bailes funk; a chácara onde está situada uma Organização Não Governamental (ONG) que presta serviço de complementação educacional. O próprio CEU Navegantes foi implantado numa dessas chácaras em 2003.

A segunda gleba, denominada Pq. dos Eucaliptos, diz respeito a um somatório de seis matrículas, totalizando a parte norte do Cantinho do Céu, e hoje compõe parte do bairro Jd. Gaivotas. Seu histórico ajuda a reconstruir, ainda que sugestivamente, sua ocupação irregular. As informações coletadas no processo judicial iluminam uma possível trajetória, relacionando a restrição da LPM à impossibilidade de lucros dos proprietários e a "negligência" da empresa proprietária dos imóveis frente ao processo de ocupação ilegal, uma vez que a área já estava "perdida" para instituição financeira. De acordo com os registros cartoriais das matrículas, a empresa J. M. Brito comprou os imóveis em maio de 1980 antes pertencentes à Empresa Pirucaia, que cultivava eucaliptos na gleba ${ }^{46}$; no mês seguinte, junho, as seis matrículas foram hipotecadas em garantia de uma dívida de Cr\$ 90.426.566,00 à Nossa Caixa Nosso Banco. Em outubro do mesmo ano, J.M. Brito solicitou Análise de Orientação (No. 0759/80) junto à Emplasa - procedimento que informa o proprietário sobre diretrizes de parcelamento do solo. Uma vez calculado o coeficiente de adensamento da gleba de acordo com a proximidade do manancial, parte da área foi enquadrada como de $1^{\text {a }}$ Categoria e parte como Classe $\mathrm{C}$, sendo permitidos 148 lotes com tamanho mínimo de $5.000 \mathrm{~m}^{2}$. Uma segunda Análise de Orientação foi realizada em 1987 (0722/87) e foram informados os mesmos índices. Diante do não cumprimento da dívida, a Nossa Caixa Nosso Banco arrematou os imóveis em 1992. Convocados para prestar depoimentos, os proprietários informaram que na época da $1^{\text {a }}$ Análise de Orientação não tiveram interesse em empreender o parcelamento do solo dado o número de lotes permitido, desconhecendo a assinatura e endereço constantes na $2^{\text {a }}$ Análise. Disseram ainda saber sobre a invasão, todavia, que esta ocorrera sem a concordância dos sócios-proprietários "sabendo que a Caixa Econômica Estadual estava executando a garantia, razão

\footnotetext{
${ }^{46} \mathrm{Na}$ entrevista realizada com Sandro Mambelli, a empresa imobiliária Pirucaia era a proprietária da gleba na época da ocupação irregular. Não era o intuito confrontar dados e informações, mas só esclarecer que, segundo $11^{\circ} \mathrm{CRI}$ informa que Pirucaia vendeu para J.M. Brito em 1980. FI 3535 do $18^{\circ}$ Volume do processo judicial da ACP.
} 
pela qual deixou a questão de lado", ou seja, não tiveram a preocupação em promover a reintegração de posse $e^{47}$.

Já a terceira gleba, de propriedade dos Irmãos Angelico Ltda. desde 1947, teve outro percurso. De acordo com Certidão de Objeto e Pé48 constante no Processo Judicial ${ }^{49}$, a empresa reivindicou a Reintegração de Posse em 1991, contra oito pessoas. A ação foi julgada procedente e os réus condenados a devolver a posse. No entanto, os mesmos reivindicaram a indenização pelas benfeitorias realizadas uma vez que alegaram adquirir os lotes de boa fé e a ação, por sua vez, também foi julgada procedente. A empresa recorreu da sentença tendo seu pedido negado e o processo acabou sendo arquivado. A briga na justiça sem resolução do conflito acabou por legitimar a ocupação, já que diante do impasse configurado pelo precedente de ressarcimento dos investimentos versus a impossibilidade de pagamento pelo proprietário, a gleba que já estava em início de processo de ocupação rapidamente fosse adensada ${ }^{50}$.

“Aspectos obscuros e sombrios", nos termos de Miranda (2002:86), compõem o cenário desse momento, anos 1980 e 1990, quando a indústria de loteamentos clandestinos vinculados a grupos políticos-partidários atuaram concretamente na ocupação não só do território do Cantinho do Céu, mas dos mananciais como um todo. Esse esquema (ou condição) seria "obscura e sombria”, já que os pretensos loteadores, no caso do Cantinho, utilizando identidades falsas, não foram localizados e muito menos punidos até o momento.

No entanto, os conflitos entre proprietários e posseiros não podem ser entendidos apenas pela questão do valor econômico. Além da questão fundiária (e o que ela representa do ponto de vista econômico) o que se disputa também é o uso destinado ao território. Na primeira gleba descrita, vemos que os chacareiros, diante do processo de ocupação irregular, buscam assegurar o status quo (reivindicando a LPM e os direitos de propriedade), não só pelo privilégio cênico, mas

\footnotetext{
47 Informações do Procedimento de Averiguação No. 49/96. Ver sistematização no Apêndice 2 - item 44. Fonte: $8^{\circ}$ volume do processo judicial da ACP.

${ }^{48}$ A Certidão de Objeto e Pé corresponde a um documento oficial que informa quem são as partes, qual o objeto da ação e em que pé (fase do trâmite) está. A Certidão citada é referente à ação de reintegração de posse movida por Irmãos Angélico contra oito pessoas em 1991 cujo processo no. 583.02.1991.163868-2/000000-000 encontra-se arquivado.

${ }^{49} \mathrm{FI} 3837$ do $19^{\circ}$ Volume do processo judicial da ACP.

50 Dona Florípes em entrevista concedida a Profa. Maria Eliza Miranda em 2002 relata o caso: "Só que do outro lado, que é da padaria, ali pra baixo, existe um pasto verde, muito bonito, sabe, que era dos Irmãos Angélico Maretto Ltda. São os donos da padaria quinze que é lá de Santo Amaro. Aí essa área quando o pessoal começou a ocupar que foi ocupada junto com o próprio caseiro dele que ajudou aquela situação toda, essa área teve contestação. Na época, quando o pessoal começou a ocupar, o oficial de justiça veio entregar intimação para todo mundo pra não ocupar, aquela coisa toda. Teve até um processo que está rolando até hoje, saiu a liminar para o pessoal desocupar. Só que o juiz fez uma liminar assim, que tinha que ser $50 \%$ para quem estava na área e $50 \%$ para os donos pagar para tirar o povo. Ficou nisso, só que o processo rola até hoje. Não parou" (MIRANDA, 2002:170).
} 
porque também na condição de moradores de uma região de baixa densidade, de ambiência rural (chácaras, grandes glebas de silvicultura), passaram a ter essa característica ameaçada. Por outro lado, a legislação restritiva ao incidir na desvalorização imobiliária das glebas que eram utilizadas para silvicultura e, portanto, ainda não parceladas em chácaras, acabou contribuindo para o processo de parcelamento irregular. Vemos que os proprietários da segunda gleba (Parque dos Eucaliptos) solicitaram duas vezes diretrizes ao órgão competente - em 1980 e 1987 - e cientes da baixa rentabilidade do empreendimento, acabaram não dando encaminhamentos ao procedimento do parcelamento do solo. Lembrando que esta gleba estava hipotecada, sendo executada em 1992, exatamente no momento do adensamento populacional. O histórico da terceira gleba encontra uma articulação mais "coesa” na execução clandestina do parcelamento. A ação de reintegração de posse eximiu o proprietário de qualquer acusação de negligência ou fiscalização de irregularidade em sua propriedade ${ }^{51}$. Além disso, as denúncias feitas do processo de ocupação irregular e ilegal aos órgãos competentes, segundo a carta anônima, aquela que iniciou o envolvimento da Promotoria, tentaram envolver não somente a administração regional e órgãos do executivo municipal, como também, órgãos do executivo estadual além da empresa de saneamento, energia elétrica e polícia ambiental, demonstrando a inocuidade do Poder Público no ordenamento e fiscalização dos processos em curso $^{52}$. Nesse sentido, o que se percebe é que a ocupação resulta da associação entre "negligência" dos proprietários das glebas e "anuência" do Poder Público responsável pela fiscalização.

Do ponto de vista da pauta social atuante nesse período, Miranda (2002:37) refaz o histórico dos movimentos sociais da zona sul desde os anos de ditadura, fortemente influenciados pela Igreja Católica em organização da população em torno a associações comunitárias, passando pelo período de redemocratização, quando novas condições "criam um espaço de organização da

\footnotetext{
51 Em entrevista a Miranda (2002:211), o promotor Carlos Alberto Amim Filho, autor da ACP relativa ao Cantinho do Céu, comenta sobre a responsabilização dos proprietários em ações de reintegração de posse, revelando práticas de conluio entre o proprietário, que tem intenção de lotear e o grileiro: "É tudo combinado. Tal da invasão branca que é como eles chamam. O loteador quer lotear, mas não quer ser responsabilizado. Antigamente ele podia fazer e não acontecia nada. Hoje em dia não é assim, já existe uma preocupação dele driblar isso. 0 que eles fazem? Chamam um grileiro qualquer, acostumado a promover invasões, que tem seu grupo, que monta a cooperativa e fala assim 'você ganha tanto e ocupa, eu entro com a reintegração, você some e depois mais para frente a gente faz um acordo'. E é o que fazem. Ele formalmente age como se sentisse violentado e sem proteção da polícia, do Judiciário e de ninguém. E no final das contas é mais um dos inúmeros processos que os juízes têm nas suas varas e que é do ser humano querer se livrar do trabalho com mais facilidade, então, o próprio juiz manda fazer um acordo, esses aí vão ficar brigando, já tem mais de mil famílias lá, faz um acordo. Ele compra a posse e você paga, vê quantas vezes dá para fazer. Nós costumamos alertar os juízes. Olha isso é uma forma de se burlar a legislação do solo. Só que a maioria dos juízes ignora e dizem 'não, eu estou apenas discutindo a posse', como se pudesse separar as duas situações".
}

52 Ver Anexo B. 
sociedade em que vão se espalhar novas 'vias' para a participação política, podendo-se buscar e encontrar alternativas para a resolução dos problemas vividos pelas comunidades". Na nova organização social e política do país, os "problemas de habitação e os de meio ambiente foram sendo tratados de maneira diferenciada, tanto em nível de abordagem quanto em nível de escala". No território tratado, segundo a autora,

Do ponto de vista da esfera do poder municipal, entretanto, estavam criadas determinadas condições que, infelizmente, tornaram possível o predomínio de práticas político-administrativas que se caracterizaram ora pela falta de rigor no cumprimento da lei, ora pelo oportunismo, especialmente quanto à fiscalização do uso e à ocupação do solo.

O movimento social por moradia, organizado e articulado com diversas tendências antagônicas do movimento político, muitas vezes, interferiu decisivamente na ação dos próprios governos municipais, restringindo a perspectiva e o sucesso de uma política de proteção das áreas de mananciais. Além disso, motivou a expansão de uma política populista e clientelista, que procurou se beneficiar, eleitoralmente, das condições produzidas pelo processo que já vinha se desenvolvendo com a prática da indústria de loteamentos clandestinos e que, no caso das ocupaçóes das áreas de mananciais, favoreceu a formação de novos "currais eleitorais" circunscritos nessas áreas, apesar de sua visível degradação urbana e ambiental (MIRANDA, 2002:47).

Segundo a mesma autora, a pauta ambientalista, partir da década de 1990, é atualizada em torno de "entidades e organizações do terceiro setor que passaram a desenvolver programas de ação, visando estruturar e dar suporte para a organização comunitária da população envolvida nos loteamentos clandestinos". Diante das contradições e urgência dos problemas da degradação ambiental, a própria SABESP estabeleceu o Programa de Participação Comunitária que incidiu concretamente em ações de conscientização ambiental e educação sanitária das comunidades, fortalecendo a luta das mesmas nos processos de regularização para atendimento do abastecimento ${ }^{53}$.

O que convém ao presente estudo é localizar a origem das lideranças locais nesse contexto, quando começaram a predominar práticas de cunho clientelista, com associação de políticos locais e associações de moradores na obtenção de melhorias urbanas para os bairros. Segundo depoimento de Dona Florípes, liderança do Cantinho do Céu, e ex-presidente da Associação de Moradores do bairro, ela fora "colocada lá", exatamente no momento em que a reintegração de

53 Miranda (2002) aborda as diretrizes desse Programa da Sabesp em sua tese de doutorado, demonstrando práticas de enfrentamentos controversos e ao mesmo tempo inovadores nesse "espaço de intersecção" como ela denomina, em referência ao período inicial de organização social e política do país após a Constituição Federal de 1988. 
posse da gleba dos Irmãos Angelico Maretto estava em curso, objetivando mobilizar a população residente contra o despejo anunciado.

Dona Florípes: Me puseram como liderança aqui. Eu não queria, mas me puseram. E aí eu fiquei. Eu morava antes no Jd Primavera, perto do Sesc Interlagos. Eu vim em janeiro de 1990. Aí foi em 91 que começou a guerra, começaram a entregar a entregar a intimação do outro lado, que ia retirar as casas, que ia remover todo mundo. Aí foi onde puseram eu aí.

Entretanto, Dona Florípes não esclarece quem a colocou lá, mas indica pelo depoimento uma possível articulação em rede, evidenciando as estratégias de poder local.

Segundo depoimento do pescador Seo João, cuja moradia era situada na gleba dos Irmãos Angelico Maretto (sua narrativa consta parte 2.1.3 do presente capítulo), a atuação de Dona Florípes é aspecto extremamente relevante na história do Cantinho:

Quando mudei pro bairro, a esperança que existia aqui era de derrubar tudo. Nós sofremos aqui nesse bairro. Dou graças a Deus a Florípes. Te juro por Deus, hoje esse bairro não tem o que ela fazia por nós aqui. Se não fosse ela não estaríamos aqui mais não. A gente pagava uma taxinha de 5 conto, se eu não me engano. Tinha reunião, a gente ia lá pro palácio do governo, ia pra prefeitura, parava a avenida, deu rolo aqui dentro pra tirar.

O histórico de lutas e conquistas que o Cantinho do Céu passou permanece na memória não só dos moradores e das lideranças locais, como também contribuiu para um processo de estigmatização de bairros vizinhos que não passaram pelo mesmo problema. Assim, para quem está do lado de fora do bairro, os conflitos oriundos na disputa da posse envolvendo juiz, mídia e mobilização popular engendraram o estigma de que estes moradores ameaçados de despejo tinham invadido a área, ainda que o imbróglio na justiça não tivesse equacionado a reintegração de posse. Soma-se a isso a ação de grupos de extermínio que se beneficiaram da irregularidade para atuar de modo violento no bairro:

Tinha muito matador aqui, tinha gente que pegava esse terreno daqui e vendia para quatro, cinco pessoas, conforme as pessoas iam reclamando, eles iam matando. Matavam mesmo. Sem dó nem piedade. Teve muita gente que morreu aqui. Não existem nomes, ninguém fala, ninguém viu. Você saía aqui e via corpo esticado na rua. Era feio, era lei da força.

A violência que pairava sobre o bairro nos tempos da ocupação inicial, hoje tem território definido, tendo adquirido outros contornos. Uma área invisível e impossível de ser delimitada em mapa, já que o medo preside ao lidar com o assunto, é a conhecida por "Sovaco" ou "Sovaco da cobra", onde são guardados produtos oriundos de carga roubada (cigarros, carnes, eletrodomésticos) e drogas. Os carros roubados, depois das peças que possuem valor serem 
subtraídas, vão parar na represa, assim como qualquer pessoa que tenha alguma atitude considerada inadequada. O "Tribunal do Crime" é a instância de acerto de contas local, onde os moradores, por sua vez, compactuam com a “justiça pelas próprias mãos". Essa área do bairro e o tema propriamente da violência, foram pouco explorados, seja pelo zelo dos depoentes, seja pela minha insegurança em adentrar nesse território.

Desde o início do adensamento da ocupação, apenas algumas benfeitorias foram realizadas: ora rateadas entre os próprios moradores, ora conquistadas a partir de interlocução com políticos locais. O único equipamento público construído nesse período foi o CEU Navegantes, inaugurado em 2003, no bairro Cantinho do Céu: "aquele CEU quando foi construído foi uma alegria pra nós". O equipamento escolar de cunho cultural é ainda hoje uma referência para os moradores no bairro: “É o nosso cartão postal”. - segundo Roseli, moradora desde 1997.

Além da infraestrutura de pavimentação, hoje a principal reivindicação do bairro é uma Unidade Básica de Saúde (UBS), sendo recorrentes manifestações no bairro reivindicando o equipamento. Os moradores são atendidos em unidades no Jd. Gaivotas ou no Cocaia, sendo insuficientes para o atendimento da demanda.

Na conversa coletiva com lideranças e moradores do Cantinho em março de 2013, as memórias de um passado recente compartilhadas no grupo majoritariamente de mulheres com idade acima de 35 anos, destacou o depoimento de Marcos, um jovem de 22 anos que naquele dia expôs suas expectativas em relação ao bairro:

Marcos: Eu não tenho muita novidade pra contar, sou novindo, eu vim pra cá em 98, acho que eu tinha 8 anos, ia fazer 8 anos em 98. Não estudava porque minha mãe não tinha conseguido vaga, quando completei 8 anos ela conseguiu uma escola lá no Maria Luiza no Eliana, onde eu acabei os estudos. A gente veio do Lucélia, uma área também invadida, aí a gente saiu de lá e veio pra cá. Eu moro na Cairu desde sempre. Eu não pensava em ficar no bairro mesmo, nunca pensei em ficar aqui, nunca quis morar aqui. Nunca tive vontade nenhuma nem de conhecer as pessoas, sinceramente. Mas de uns 2 anos pra cá minha cabeça mudou, eu conheci umas coisas, vi um mundo diferente. Eu vi as pessoas diferente. Aí eu resolvi entrar, sei lá, num projeto social, com o CEU, ver coisas novas, conhecer as ruas, procurar algo pra melhorar o bairro. Eu não pretendo mesmo ficar muito tempo mais. Mas o tempo que eu vou ficar eu espero conseguir algo de melhor pro meu bairro, pra quem seja, quem ficar né. Eu comecei a fazer faculdade esse ano, de Radio e TV, na Barão de Itapetininga, no centro. Levo duas horas e pouco, porque eu pego o Praça da Sé né, que vai direto. Mas a gente nem sabe porque se eles tirarem o Praça da Sé daqui pro Terminal Grajaú vai ficar pior a situação. As condições não permitem né eu ir de trem, se o ônibus faz o trajeto direto e eu consigo gastar menos por causa do bilhete único de estudante... Sai mais em conta pra mim. Porque se eu quiser correr, e viver a minha vida, eu dou tchau e vou. Estou começando minha faculdade agora mas só que se eu puder fazer algo de bom é muito melhor. 
Havia rumores naquele momento de retirada da linha de ônibus Cantinho do Céu-Praça da Sé. Desde 2008, quando o Terminal de trem Grajaú foi inaugurado, as linhas de ônibus da região começaram a sofrer alteração de itinerário, conectando os bairros ao Terminal, substituindo as linhas diretas. No entanto, apesar de ser uma boa solução para o planejamento urbano, o bilhete único de estudante não vincula a integração com o sistema ferroviário, cobrando uma segunda passagem. Além disso, o tempo gasto em trânsito seria aproximadamente o mesmo, segundo Marcos.

Marcos abandonou a faculdade e algum tempo depois, em associação a outros amigos, montou o coletivo cultural Transação, que tem promovido bazares de roupas usadas e sabonetes artesanais em eventos culturais na região. Em contraposição à narrativa coletiva sobre um passado de lutas que as mulheres tinham vivenciado, Marcos pela idade, por ter vivenciado o bairro na fase infantil, não traz consigo o mesmo sentimento. Pelo contrário, vislumbra o futuro, deixando transparecer um possível anseio em sair do bairro: "porque se eu quiser correr, e viver a minha vida, eu dou tchau e vou". Os depoimentos femininos revelavam o envolvimento dessas mulheres no histórico conflitivo da ocupação. Mas não só isso, sendo que evocavam um passado de trabalho num contexto de lutas por melhorias para o bairro. O depoimento de Dona Florípes, liderança do Cantinho do Céu, 60 anos, refaz seu percurso:

Eu briguei muito pelo Cantinho do Céu... hoje eu estou doente. Hoje eu estou doente por causa disso (começando a chorar), eu fiz muita coisa, briguei muito sabe... E hoje eu trouxe pra mim a consequência disso. Hoje eu estou doente, tive três enfarte. Só que são poucas as pessoas que reconhecem o que eu fiz. Porque quando eu olho o Cantinho do Céu desse jeito, eu fico pensando na minha briga, briga com promotor, com juiz, respondi processo, quase fui presa. Por causa do Cantinho do Céu. Só que hoje ainda tem muita gente que reconhece, que nem essa aqui, aquela ali. Mas tem muita gente que não reconhece, que passa por mim e vira a cara. Mas Deus tá lá em cima, Deus sabe o que eu fiz. Eu agradeço a Deus porque Deus nunca me desamparou. Deus tá do meu lado e nunca me desamparou. Mas eu tive três enfarte. Quando eu falo, me emociono, é porque eu sei o que eu sofri. Eu sei o que eu sofri. E sabe o que é você estar na frente do juiz e o juiz querer te prender, e você falar: eu não vou presa porque eu não devo nada. Eu não roubei, eu não matei, eu estou defendendo o povo, que precisa viver, precisa de sua moradia, precisa de seu lar. Então eu enfrentei, eu enfrentei mesmo. Hoje tem político aí fora que fala, que reconhece, que viu, que me acompanhou, que no dia que eu fui na frente do juiz teve três políticos que foram atrás pra me defender. Eu sei o que eu passei pelo Cantinho do Céu. Eu sei. E tem muita gente que viu, que reconhece, que fala, entendeu? Perdi duas casas aqui dentro, entendeu? Tinha uma casa, vendi. Comprei outra, vendi. Fui ameaçada aqui dentro. Olha, não dá nem para contar. Porque se eu for relatar a minha vida, minha história dá um livro. Só que os depoimentos que eu dei foi referente ao bairro, à necessidade das pessoas. Eu defendi a tese que ninguém invadiu aqui, 
todo mundo comprou de terceiros. Dra Elza falou: - Dona Floripes a senhora não pode vender aqui. Porque depois eu comecei a participar, comecei a aprender o que era mananciais. A vida é uma escola. Você aprende com a vida. Tem pessoas que me condenam. Mas eu era leiga, eu não sabia. Só que eu não vendia. Eu intermediava! Mas vai explicar pra eles o que é intermediar, ninguém entende. Intermediar é a senhora ter um terreno, a senhora chega em mim e dá para eu vender, mas quem na realidade tá vendendo é a senhora. Eu só estou intermediando. Eu fiz algumas intermediações aqui dentro, depois eu parei. Mas uma coisa eu digo para você, só apareceu gente boa na minha vida. Até hoje tenho fotos, tenho lembranças, sabe, de pessoas que passaram pela minha vida que só me ajudou a ajudar o povo do Cantinho do Céu. Tudo bem que as pessoas não reconhecem, mas Deus lá em cima... E eu estou aqui, depois de três enfarte... Porque eu sei que eu ainda tenho alguma coisa para fazer, eu não sei o que eu vou fazer, mas que eu tenho eu tenho, porque depois de três enfarte, só Deus na minha vida, só Deus. Então eu acho que eu ainda tenho alguma coisa, eu não sei o que é, mas eu tenho alguma coisa. Acho que só depois que meu Cantinho do Céu todo urbanizado, tudo bonitinho é que eu vou. (...) Mas eu estou aqui, pra contar história. E só vou morrer agora se Deus quiser. Que eu não sei quando que é né, mas ele sabe. (...) Então, acho que depois que sair a UBS, o Cantinho do Céu ficar bom, aí eu vou parar. Aí Deus me tira, que aí eu vou satisfeita. Hoje a gente vê, eu vejo o Cantinho do Céu desse jeito, menina, eu fico vendo assim: sabe quando passa assim um filme na tua mente, quando você mudou pra cá que não tinha nada, água, puxando lá de baixo, luz com gambiarra, assim, passa aquele filme, passa aquela luta que você teve. A polícia querendo me prender, o oficial de justiça lá embaixo, o povo tudo comigo lá embaixo, lembra?

Dona Florípes protagoniza o período do bairro quando os conflitos de ordem jurídica acontecem, entrelaçando sua história de vida à do bairro. Quando recorda o que viveu, seu depoimento é envolto de grande ressentimento em relação ao período, principalmente pelo não reconhecimento em relação ao seu esforço de anos perante o bairro.
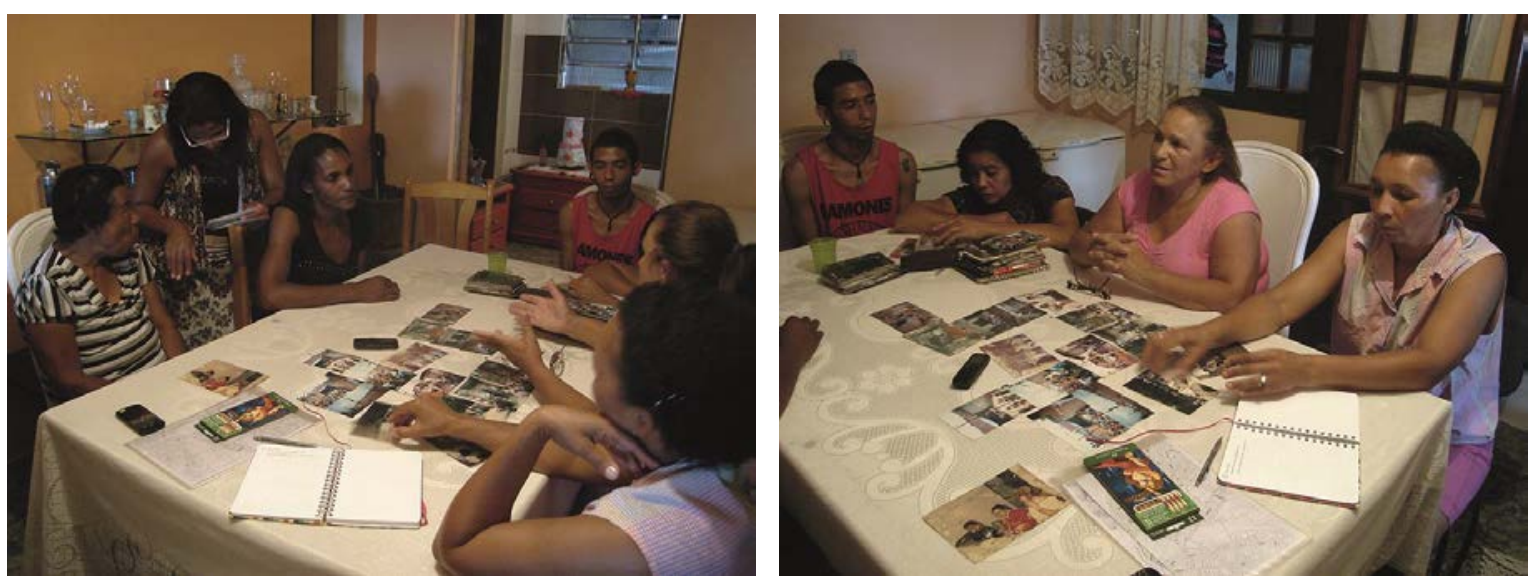

Figura 21 - Conversa coletiva em março de 2013 na residência de Dona Rosa. Crédito: Melissa Matsunaga, 2013.

Dona Rosa, 55 anos, liderança do Cantinho do Céu elucida o trabalho realizado e como é visto pelos moradores:

Dona Rosa: É porque a gente trabalha tanto, e quando chega no fim, assim, as pessoas não tira foto, não vê nosso trabalho, e ainda sai falando da vida da gente, 
sabe, não valoriza o nosso trabalho. Aí quando chega o fim dos tempos, você chega numa certa idade, e ainda você ouve, quando você passa pelos lugares, as pessoas falando mal de você. As pessoas acham que nós trabalhamos e que nós somos remuneradas e que nós ganhamos muito bem. Essa menina trabalhou poucos dias comigo, trabalhava na época da eleição comigo, que eles ganhavam setecentos, oitocentos reais e eu ganhava mil para cuidar de 40 pessoas. Entendeu? Aí termina a eleição você não ganha mais nada. Acabou. E aí seu vizinho acha que você trabalha na política e que você ganha dois, três mil reais. E tem dia que você não tem dinheiro nem para comprar café, imagina para ir na.. [reunião], entendeu?

A fala de Dona Florípes remete a um momento "áureo" da atuação das lideranças. Ainda que sob forte influência partidária e possivelmente realizando "trabalho de base", as lideranças mobilizadas e articuladas com os políticos locais ajudaram a consolidar o bairro, colocando-se a favor dos moradores e enfrentando ameaças e constrangimentos públicos. Depois que a urbanização do bairro começou a autorreflexão e as possibilidades de atuação dessa nova conjuntura, nota-se que não é positiva, ou seja, é como se elas estivessem em descrédito sobre suas lutas, já que sua representatividade perante o coletivo começa a ser questionado.

\section{Seo João do peixe e Angela}

A Piratininga que lasca nossa represa aqui, e por quê? Porque quando chove pra lá, que enche o rio Pinheiros, ela bombeia para cá. Eu já vi várias vezes. Agora você condena nós que estamos aqui. Quer tirar da beira da represa que tá poluindo, mas não é isso aí. É o grandão aí. O principal que polui a represa é a Usina Piratininga.

João Mateus dos Santos Filho, conhecido no bairro como Seo João do peixe, tem 41 anos e estudou até a $2^{\text {a }}$ série do $1^{\circ}$ grau (atual $3^{\text {a }}$ série do Ensino Fundamental). Natural de Ribeirão-PE mudou-se para São Caetano em 1989, ainda menor de idade. Ele é casado com Angela, 41 anos, desde 1997 e, atualmente, o casal tem dois filhos, Sara de 15 anos e João Vitor de 14 anos.

Logo no início da entrevista, ao perguntar sobre sua família, João me contou sobre uma desavença séria com a irmã que "roubou" a casa da mãe, e ao saber do ocorrido, destruiu à marretada essa moradia no interior de Pernambuco: "eu falei: mãe, quer ir embora pra São Paulo, lá tem onde a senhora morar. Tudo isso aqui que eu tenho hoje, isso aqui é suado, não é roubado". Seo João até hoje é brigado com a irmã devido a esse acontecimento. A mãe recusou a proposta e continua morando em Pernambuco, tendo sido essa ocasião da derrubada da casa a sua última visita.

Angela, esposa de João, veio da Bahia em 1989 e morava em Santana antes de se casar com Seo João. Seus pais se mudaram recentemente para o bairro, segundo Angela, sua mãe "veio na dor" devido à morte de um de seus irmãos ocorrido na Av. Belmira Marin, num acidente de moto. Angela trabalha 
como diarista, mas está afastada do trabalho desde 2010. Ela está com um câncer raro no fígado, já fez uma cirurgia, continua em tratamento e atualmente está na fila para transplante.

Uma "história difícil" é o termo que João utiliza ao enredar-se em sua trajetória até os dias de hoje. Em busca de uma alternativa ao corte de cana de açúcar em Ribeirão, Pernambuco, atrás de melhor salário e condição de vida, João veio só para São Paulo. Ele tinha 16 anos quando resolveu morar junto ao irmão mais velho. Começou trabalhando ilegalmente numa fábrica de vassouras em São Caetano do Sul: "como eu era de menor, eu não podia trabalhar, aí o patrão me encaixou lá sem registro. Trabalhei sem registro um ano e três meses eu não me engano". Nesse período, o jovem João morou em casa pertencente à fábrica, onde contou que "um ladrão roubou os sapatos, cobertores nossos. E então o patrão nos levou na loja, compramos as coisas de novo para ir pagando aos poucos. Trabalhei mais de um ano para pagar tudo". A condição de trabalho degradante, análoga à de escravo nos termos da leir", foi acentuada pela relação conflituosa com o irmão, que lhe tomava o salário que sobrava ao final do mês.

Assim, ao completar 18 anos, desvinculou-se do irmão, configurando sua própria trajetória na metrópole paulista. Logo Seo João conseguiu emprego em outra fábrica de vassouras em Santo Amaro e no início desse período, mais uma vez, residira em casa da empresa até a decisão de comprar um lote no Cantinho do Céu, em 1992, localizado à Rua Bonfim, próximo à represa: "quando eu vi a represona, aqui eu teria um emprego meu porque eu já sabia pescar. Esse marzão de água, uma riquera danada. Se quiser comer peixe tem aí. Era só mata lá embaixo, o peixe você olhava e via ele na beira d'água".

A situação urbana do bairro ocupado irregularmente era expressiva: "ali era uma gambiarra só". Na condição de ser um dos primeiros moradores, Seo João interpela: "ali quem viu criar fui eu" e se orgulha em dizer mais uma vez: "tudo que o tenho é suado e tudo o que faço dá certo". A construção da casa em meio ao bairro que começava a se adensar foi lembrada por atitudes de coletividade, de ajuda mútua e de investimento individual não só de material de construção para a moradia, como também, de infraestrutura urbana, como fiação de energia elétrica (ainda que clandestina). No entanto, mesmo num movimento conjunto, de agregação comunitária, Seo João lidou com pessoas que queriam se beneficiar da situação urbana precária e clandestina, como roubo de seu material de construção até a sabotagem da leitura do fornecimento de água ${ }^{55}$ - atitude esta que ocorre até hoje e que ele reprova:

54 Segundo Art. 149 do Código Penal, a servidão por dívida configura crime contra a liberdade individual, cuja pena é de dois a oito anos e multa. Para crimes cometidos contra crianças ou adolescentes a pena é aumentada de metade.

55 Segundo dados do processo judicial, a Sabesp autorizou a implantação da rede de água no bairro em outubro de 1990. 
- Era uma mangueirinha desta grossurinha aqui ó para cinco casas. Era a minha, tinha um cara que cuidava das minhas coisas que era o próprio ladrão do bairro... - Como assim?

- Tipo assim, você não trabalha certo? Aí eu digo assim: eu dou um troquinho pra tu olhar meu terreno aí. Beleza. Encostava o caminhão de bloco, comprava cinco mil blocos, um caminhão de areia e quando eu ia lá mexer não havia nada. Roubaram as colunas. Eu fui me aborrecendo e um dia eu peguei ele roubando. Falei, pô meu, eu falei pra você olhar meu terreno e o ladrão é você, velho? Peguei os irmãos dela [Angela] mais dois pedreiros e dentro de uma semana a casa já estava em meia parede. Pra ninguém roubar mais nada. Aí teve o mutirão da laje, teve meu patrão e um monte de gente lá. Montei a laje, pedi pro caminhão chegar cedo, foi tudo, areia, cimento, pedra. Assim que chegou o material fizemos tudo, fizemos churrasco e viemos embora. A chuva caiu. Aí veio a parte do acabamento. Fiz rolo com um fusca que eu tinha, pedi pro irmão dela rebocar. Aí deu até azar, pois ele vendeu o carro, roubaram o dinheiro no ônibus, deu um rolo danado. Ele mora lá apegado com essa casa. Estava todo mundo construindo. Hoje se você for lá pra baixo, daqui pra lá é cinco minutos, se você for lá hoje, só não tem asfalto, tem água, tem internet, tem luz. Antigamente era um monte de fio, era gato. Antes tinha aquele relógio de ferro, só que lá ninguém quer pagar nada. Eu acho uma vergonha você morar num lugar que chega 5 reais de água e você não conseguir pagar. Acho uma sacanagem. Você trabalha, meu amigo, tem seu carro. Eu vejo gente lá com o relógio cortado por cinco conto de água! Aí também não né. Hoje em dia todo mundo tem as coisas lá, tem carro, tem energia, não tem mais aquele problema de você ligar o chuveiro e a TV desligar. Nós éramos desse tempo lá. Eu gastei 100 rolos de fio pra puxar lá de cima, um fio mais grosso. Eu gastei pra ter uma energia boa. E não tinha, pegava fogo em tudo. Hoje tá bom. Uma casa lá hoje vale 40 mil, 25 mil, depende da casa entendeu?

Seo João comenta sobre o aprendizado obtido ao ver e participar de construções. E através do seu esforço próprio, que é sempre enfatizado, e revela que não quer mais trabalhar para os outros:

Ali eu não sabia esticar uma linha de pedreiro. Você vai olhando e vai aprendendo, vê o cara fazendo massa, ajudando o rapaz a fazer o mutirão de uma casa. Muita coisa que eu faço hoje, eu não trabalho para os outros porque eu não quero. Eu não quero trabalhar pra ninguém mais. Pra mim eu trabalho! Na casa da rua da paz eu que montei a laje e chamei o caminhão para concretar. Ganhei dinheiro no peixe, na piracema não pode trabalhar, eu trabalho pra mim.

Segundo Seo João, foram gastos cerca de quinze mil reais na construção da primeira casa onde morou, que ele decidiu vender "fiado" para um colega de trabalho que morava de aluguel pelo valor de sete mil. No entanto, até hoje o amigo não quitou a dívida e é uma pessoa a quem não se sente à vontade em cobrar, apesar de lhe causar constrangimento por "ter lhe estendido a mão" num momento em que ele próprio não contava com muitos recursos financeiros. Ao negociar a casa da Rua Bonfim, Seo João comprou a casa onde mora atualmente, localizada à Rua Paraíba, no próprio bairro, que segundo ele “não tinha portas" quando se mudou, em 2001. 
Em 2002, a saída da empresa de vassouras de Santo Amaro foi marcada por processo trabalhista: "essa firma tá com processo, tenho 38 mil pra receber. Trabalhei 9 anos! Tá lá o processo até hoje pra receber. Não pagaram INPS; adoeci; fiz uma cirurgia no joelho; sarei; só que o médico falou assim: 'não faça mais o que você faz'. Daí eu fiz o quê? Botei a firma no pau”. Para produzir as vassouras, o trabalhador fica em pé em sua jornada diária, junto a uma prensa utilizando pedais, o que acabou prejudicando os tendões da perna de Seo João e o impossibilitando na continuidade desse labor.

O fato de não ter estudos imputou a si mesmo uma barreira em conseguir outro emprego. Assim, a localização de sua moradia próxima à represa se apresentou como um chamado à atividade da pesca. O ofício que aprendera quando criança no interior de Pernambuco lhe pareceu uma atividade possível de realizar, já que não prescindia de estudos. Era só uma questão de tempo e de adaptação para lidar com a rede e o barco motorizado. No entanto, as barreiras da falta de um diploma não eram imaginárias. Mesmo conseguindo o registro como pescador profissional, Seo João encontrou empecilhos para obtenção da carteira de habilitação profissional56, o CIR, que poderia the abrir novas oportunidades de emprego, como operar balsa ou outras embarcações profissionais. Segundo o pescador, para obtenção desta carteira profissional, o sujeito "precisa de estudo" e, assim sendo, acabou ficando apenas com a carteira de habilitação de amador, que exibe com orgulho sua documentação em dia: "eu ando com ela porque aqui quase ninguém tem" (Figura 22).

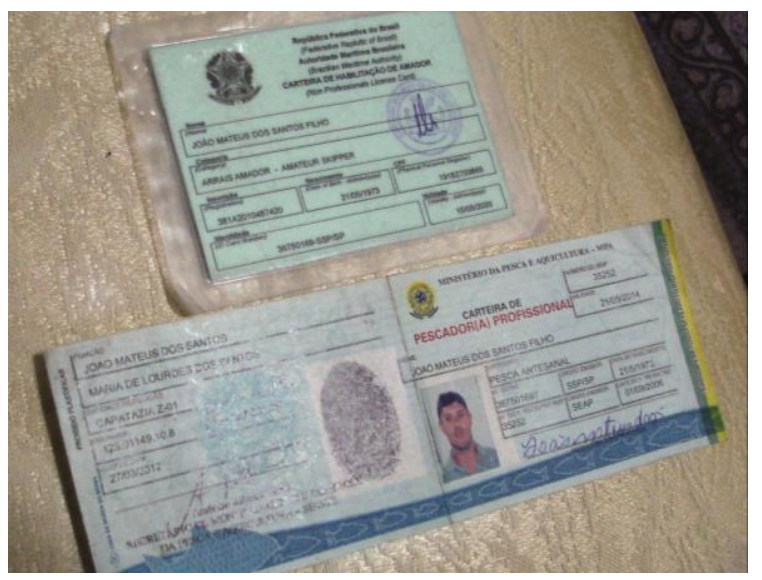

Figura 22 - Habilitação de barco e carteira de pescador de Seo João. Crédito: Melissa Matsunaga, 2013.

Seo João é associado de uma colônia de pescadores de São Bernardo do Campo e comercializa os peixes com venda na sua própria casa. Os recursos oriundos da venda do pescado complementam a renda familiar.

56 Para operar embarcações é necessário o porte da Caderneta de Inscrição e Registro (CIR) expedida pela Marinha do Brasil após aprovação em curso realizado pela Capitania dos Portos. 
A primeira entrevista, em julho de 2013, que acabou se transformando numa "visita demorada", fez com que eu participasse do almoço, cuidadosamente preparado por Angela. Nesse mesmo dia, Seo João fez questão de me levar para dar uma volta de barco na represa, me mostrando a quantidade de lixo próxima à Usina de Pedreira - que ele chama de Usina Piratininga ${ }^{57}$ - pois já presenciou muitas vezes o processo de bombeamento da água advinda do canal que liga o Rio Pinheiros à Represa. Devido a isso, não acha esse ponto o mais adequado para lançar a rede. Além disso, fez questão de me mostrar também as carcaças de carros roubados que são jogados na represa, me revelando aspectos que acontecem nas margens do bairro visíveis apenas a partir da represa e da margem oposta. Os carros jogados são invisíveis para quem está no bairro. O ofício de pescador permitiu a Seo João um conhecimento empírico do processo de degradação que o manancial sofre com o bombeamento sistemático do Rio Pinheiros para a Represa:

A Piratininga que lasca nossa represa aqui, e por quê? Porque quando chove pra lá, que enche o rio Pinheiros, ela bombeia para cá. Eu já vi várias vezes. Agora você condena nós que estamos aqui. Quer tirar da beira da represa que tá poluindo, mas não é isso aí. É o grandão aí. O principal que polui a represa é a Usina Piratininga".

Mantivemos contato por telefone e numa segunda visita à família, em setembro de 2014, acompanhei de perto a atividade da pesca. Angela e Seo João compraram um barco maior, cuja entrega foi tumultuada já que a carga foi roubada antes de chegar ao bairro, causando grandes transtornos e prejuízos financeiros. Uma vez resolvida a entrega do novo barco, as atividades de pesca passaram a fazer parte do cotidiano de Angela, que começou a acompanhar e auxiliar o marido, inclusive pensa em tirar sua carteira profissional em breve. No novo barco, o casal demonstrou grande habilidade no manejo da rede: enquanto um direciona o barco com o remo, o outro lança a rede de mais ou menos $300 \mathrm{~m}$ de comprimento para o fundo da represa. A rede permanece esticada, pois são implantadas longitudinalmente peças de chumbo na parte inferior e boias na parte superior. A rotina diária tem dois turnos: logo de manhã, João e a esposa saem para esticar a rede, onde a deixam até o final da tarde. Perto do pôr do sol, eles voltam para puxá-la. Muitas vezes, além dos peixes, muito lixo também é pescado.

A pesca na represa é proibida na época de reprodução dos peixes, de novembro a fevereiro. Nesse período os pescadores recebem um salário mínimo pelo seguro-defeso, auxílio financeiro temporário garantido por lei aos pescadores registrados no Ministério da Pesca e Aquicultura. Como

${ }^{57}$ A Usina Termoelétrica Piratininga é localizada ao lado da Usina Elevatória de Pedreira, às margens do canal Pinheiros e em seu processo de geração de energia, utiliza água para produção de calor. 
Seo João gosta muito de pescar, esse período não lhe agrada muito, ao contrário de outros, que, segundo ele, se cadastram na associação de pescadores mais pelo auxílio financeiro do período do que pelo exercício da atividade.

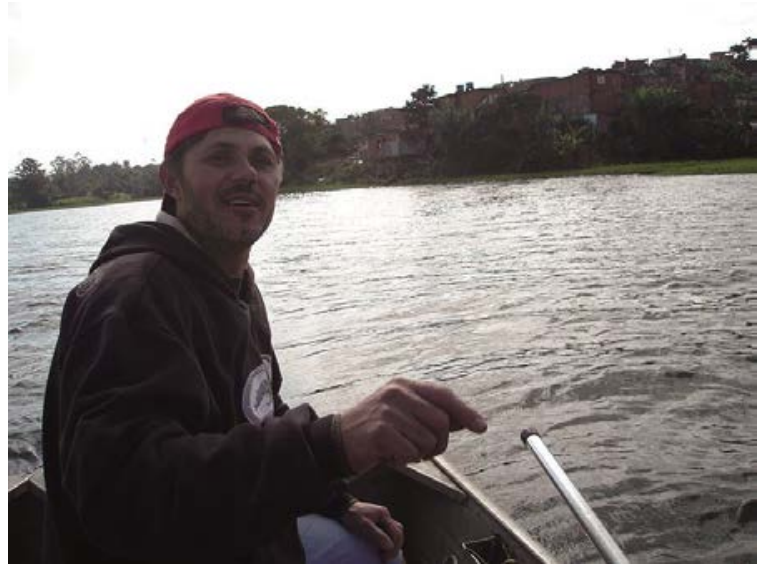

Figura 23 - Seo João em passeio de barco na primeira entrevista. Crédito: Melissa Matsunaga, 2013.

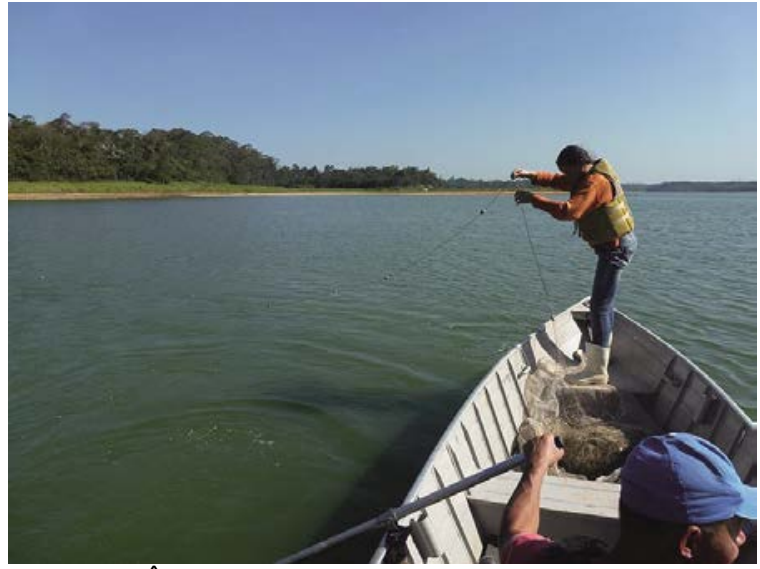

Figura 24 - Ângela soltando a rede na represa. Crédito: Melissa Matsunaga, 2014.

Com o passar do tempo, Seo João não só finalizou a casa onde mora, como também a ampliou com a construção de três cômodos independentes que são alugados. Além disso, é também proprietário de outra casa no bairro, na Rua da Paz, subdividida em outros três cômodos também alugados. O valor do aluguel de cada cômodo representa a maior parte do orçamento da família. O recente aniversário de 15 anos de Sara, que contou com tradicional festa de debutante, colocou novos horizontes para a atual moradia: planejam aumentar a casa, incorporando um dos cômodos de aluguel para o novo quarto de Sara.

A partilha de alguns momentos em família permitiu perceber que a preocupação dos pais em relação ao cotidiano dos filhos no bairro é grande. Devido a isso, Seo João não permite que João Vitor brinque ou permaneça demasiado na rua com outros meninos, pois entende que na rua seu filho está suscetível ao agenciamento do tráfico de drogas.
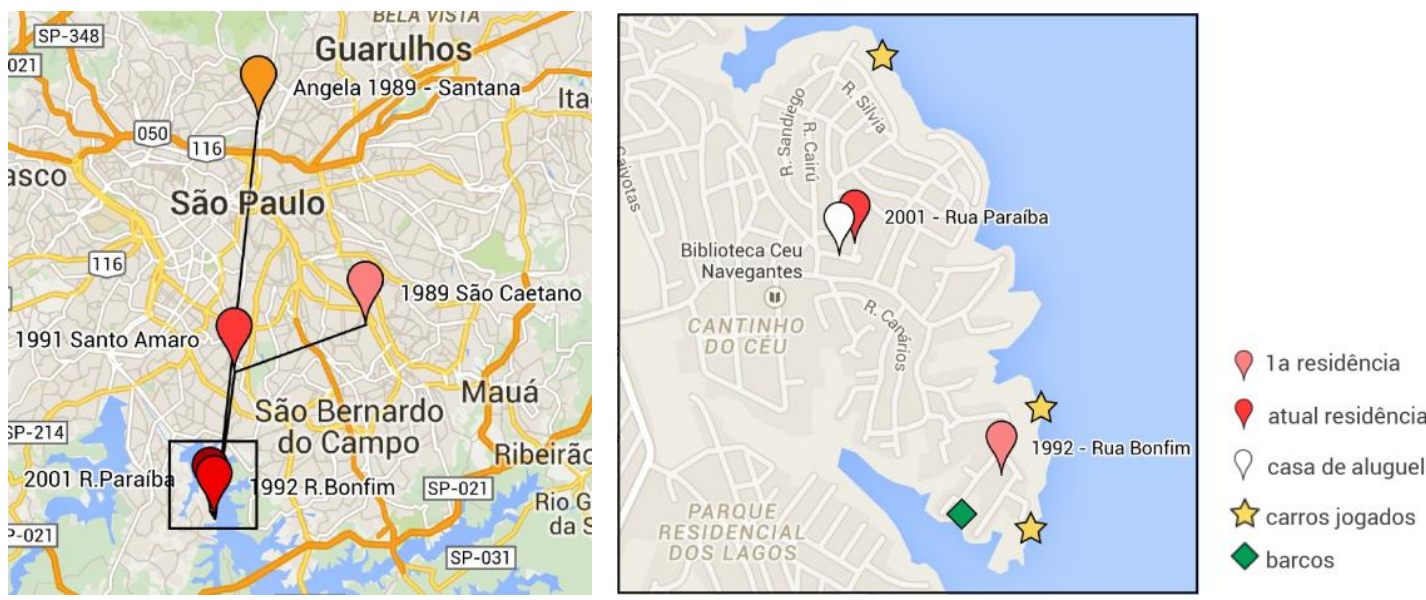

Figura 25 - Locais de moradia de Seo João e Angela. 


\subsection{O Parque Residencial dos lagos}

Comprei em 87. Até construir, construindo... Vindo de final de semana, só podia vir em final de semana. Era um loteamento novo, era uma casinha ali e outra lá em cima. Não tinha luz. Não tinha água. A gente teve que fazer poço.

Três glebas irregularmente parceladas como condomínio constituem o denominado Parque Residencial dos Lagos: Lago Azul, Lago Dourado e Recanto dos Cisnes (Ver Figura 20). Apesar da “institucionalização" do nome, o bairro é popularmente conhecido na região como Lago Azul. A comercialização dos lotes, feita por imobiliárias locais e sem aprovação na Prefeitura ou Governo do Estado, foi iniciada por volta de 1987 e a ocupação do bairro deu-se alguns anos mais tarde, sendo que no início, não havia infraestrutura instalada, apenas a abertura das vias. Segundo a liderança do bairro, Dona Vera:

Eles lotearam isso como um condomínio fechado. Mas eles tinham que deixar isso aqui com infraestrutura total, só ia entrar o asfalto depois. Era água, luz, guia, sarjeta, tudo. A proposta era essa, que ia ter tudo isso, por isso era condomínio com guarita, com guardas, que ia ser um bairro fechado. O Sipramar loteou o Lago Azul e o Lago Dourado, e o Nelson só loteou o Recanto dos Cisnes.

Em conversa coletiva realizada no parque linear em 2013, Dona Vera, liderança comunitária do Parque Residencial dos Lagos, Seo Cunha e Seo Manoel, antigos moradores, abordam a irregularidade da área que foi deflagrada por eles após a compra dos lotes:

Dona Vera: Só que como eles podiam fazer isso numa área irregular? Que não podia ser loteado de $5 \times 25$, era acima de $500 \mathrm{~m}^{2}$, mas nós não sabíamos disso. A ganância deles [imobiliária] foi tanta... aí quando a porca torceu o rabo eles caíram fora. Porque eles não tinham condições de colocar asfalto, eles não tinham condições de colocar uma água, colocar um esgoto, nada. Porque era um terreno irregular. Não podia ser loteado. Só que nós compramos na boa fé. Ó, Pabreu, Montes Verdes, Jequirituba, a maioria do Recanto do Cocaia, Gaivotas, Cantinho do Céu é tudo invasão. O único lugar aqui que foi abençoado por Deus, que foi loteado e comprado e nós pagamos foi o nosso. Existe uma diferença aí. Nós compramos uma coisa irregular, nós compramos, mas nós não sabíamos.

A conjuntura econômica do período também foi lembrada nesse momento:

Dona Vera: Só que a Sipramar, o que é que ela fez? Ela vendeu com $60 \%$ do salário mínimo. Aumentava $60 \%$ todo ano, conforme o salário aumentava, e foi aquela época da inflação, que a inflação subia mais que... aí o povo não aguentou pagar.

Seo Cunha: Teve nego que não pagou não.

Dona Vera: Teve muita gente que não pagou nada. Tem o contrato de compra e venda registrado em cartório e tudo. Ó, e aí o que é que aconteceu? Eles caíram fora porque iam ser presos. O Nelson pagava IPTU da terra dele, porque é dele 
mesmo né. Aí começou a cobrar de nós, depois não cobrou mais. Quando eles viram que a casa ia cair pro lado deles, eles largaram nós na mão. Aí o pessoal começou a pagar em juízo. Foram pra prefeitura, arrumaram seus advogados e começaram a pagar em juízo. Muita gente terminou de pagar assim.

Seo Cunha: Teve um monte de neguinho que sofreu pra pagar, eu lembro.

Segundo Richards (2011) - com base em informações constantes em processo administrativo da SEHAB, que trata sobre a regularização do parcelamento correspondente ao Parque Residencial dos Lagos, composto por três glebas ${ }^{58}$ - o parcelamento clandestino foi deflagrado pela Prefeitura desde seu início, em dezembro de 1987, que aplicou a partir de 1989 as devidas sanções administrativas aos loteadores para regularização das três glebas. De acordo com a autora, foram cinco imobiliárias criadas com o intuito de empreender o parcelamento clandestino: Empreendimentos e Construções TRC Ltda., Portal Imóveis e Empreendimentos, JBS Empreendimentos Imobiliários S/C Ltda., Sipramar Empreendimentos e Participações S/C Ltda. e Imobiliária Parelheiros. Contudo, devido ao esgotamento da negociação administrativa - com a aplicação de multas, acordos e depósitos em juízo por parte dos moradores - houve a instauração de uma Ação Civil Pública em 2003 envolvendo as imobiliárias e seus responsáveis, além da Prefeitura e Governo do Estado, para efetivar a regularização e a indenização aos moradores. Segundo Richards (2011), esta ACP continua em andamento após recurso de apelação por parte da Municipalidade e do Estado. Convém destacar que esta $\mathrm{ACP}$ não corresponde à mesma tratada no presente trabalho.

Do ponto de vista do desenho urbano, o parcelamento do solo, ainda que ilegal, do Residencial dos Lagos, se configura de modo ordenado, com eixo viário definido, lotes com alinhamento e dimensões padronizadas. E nota-se uma característica urbanística: não há vielas, a não ser apenas uma, que fora aberta pela intervenção para realizar conexão de redes de drenagem urbana, no mais, quando se caminha pelo bairro, ainda que seja necessário o fazer pela rua, pois a calçada é bem estreita, pensa-se estar num bairro "planejado". A planta de venda dos lotes (Ver Figura 26) demonstra não apenas o parcelamento do solo, como também a implantação das unidades residenciais, configurando o "pacote" quando se comercializa uma unidade num condomínio residencial.

58 Processo Administrativo 1998-0.000.987-5 - Programa Mananciais SEHAB/PMSP. 


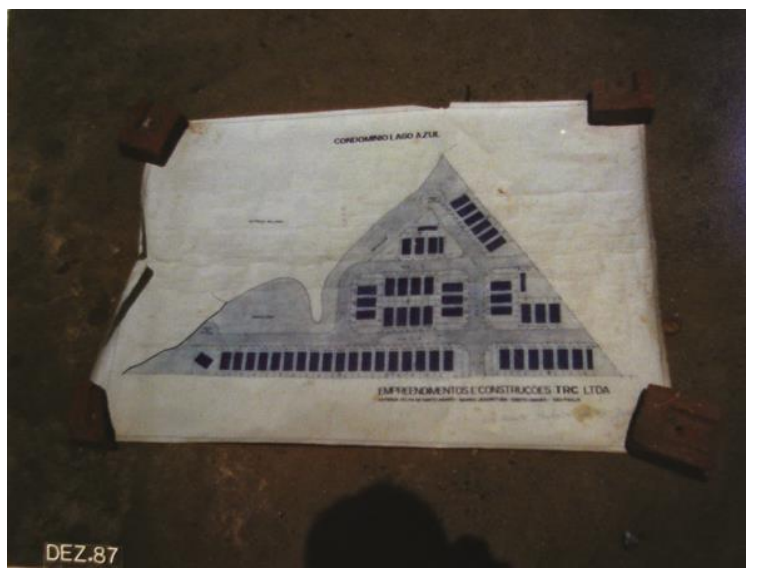

Figura 26 - Planta utilizada na venda dos lotes - gleba Lago Azul. Fonte: Processo administrativo 1988-0-000-987-5 Programa Mananciais/SEHAB-PMSP.

Ainda que a compra dos lotes num condomínio reservasse certos "privilégios" e "status" por essa condição urbana exclusiva (ainda que de modo imaginado) aos adquirentes, os primeiros serviços urbanos foram conseguidos a partir do envolvimento das lideranças com os políticos locais, visto que a luz, água e correio foram os primeiros a serem conquistados. Ainda que de maneira informal, seu acesso conferia o início da consolidação do bairro. Dona Vera, a liderança local que também é uma das primeiras moradoras, narra sobre a nomeação das ruas e o envolvimento com vereador para obtenção do serviço de correio atrelado à criação do endereçamento:

- Como foi a nomeação das ruas? Quem escolheu esses nomes de pássaros?

- Fomos nós. Nós fizemos uma reunião com alguns moradores num final de semana, depois nós fizemos uma reunião com a diretoria [da associação dos moradores]. Aí nós começamos assim: pô a gente mora envolta de uma represa né, tem muitos pássaros. Os pássaros que nós colocamos, que nem Graúna. Graúna é uma ave que dá na mata né. Patativa do agreste! Essa ave patativa do agreste é lá do nordeste. Então cada um de nós da diretoria dava um nome. Mas aí era Patativa, não era Agreste. A rua Graúna, rua Cisne, rua Araras, rua Garças, Canário. Só que quando foi levado pro correio central, que eu fui lá e levei, entreguei tudo, porque é tudo mapeado, bonitinho. (...) Quando chegou lá o correio não aceitou, brecou. Em Moema já tinha esses nomes. Moema e tem outro bairro aqui em São Paulo que tem. Aí o que aconteceu, eu fui pro escritório do [vereador] Estima. Falei, gente do céu, o correio não aceitou, o que que nós vamos fazer? (...) Ficamos sabe estudando, estudando. Daí fizemos uma reunião com a diretoria novamente: que pássaro que tem no nordeste? Tem a patativa: Patativa do Agreste. O Cisne Azul é tão preto preto preto que chega a ser azulado. Então vamos por Cisne Azul. Rua Canário: Belga. Bem-te-vi: Marrom, que ele é meio amarronzado né? Hum, que mais? Garça, ela é tão branca que chega a ser prateada. Araras Amarelas. E fomos fazendo isso. Pavão Dourado! Aí o correio aceitou. (...) Foi quando nós fomos fazer toda a documentação do correio, aquelas coisas todas. Aí para fazer Lago Dourado, Lago Azul, ia ser complicado. Então nós resolvemos fazer um só, que é Parque Residencial dos Lagos. 


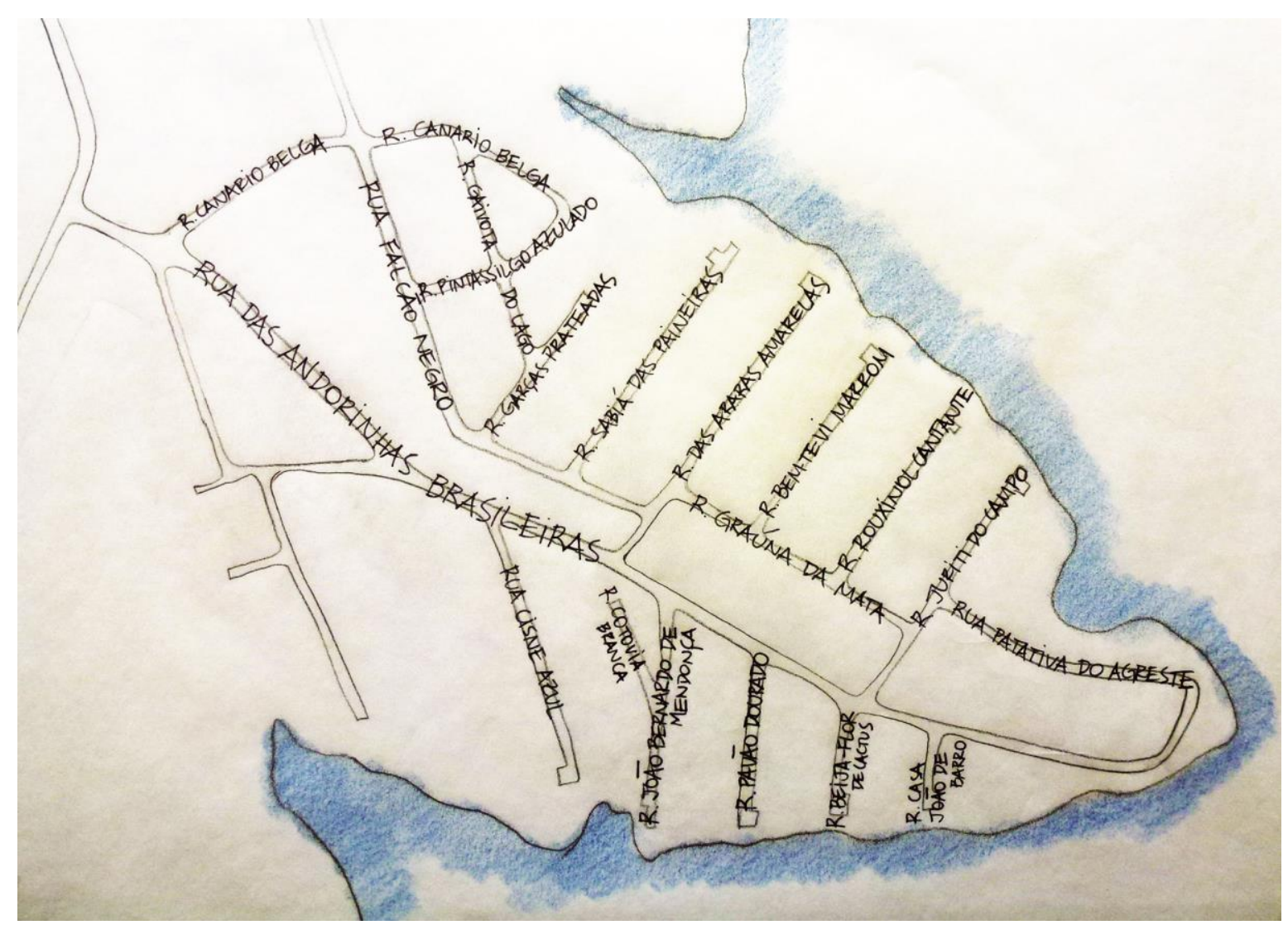

Figura 27 - Nomeação das ruas com nomes de pássaros realizada pelos moradores. Elaboração: MATSUNAGA (2015).

Dona Lourdes, cuja narrativa trato no item 2.2.2 deste capítulo, moradora antiga do bairro e que atuou no início da formação do bairro junto à Dona Vera. Ela narra sobre a homenagem feita pelo vereador, atribuindo o nome de seu falecido marido à rua em que mora:

\begin{abstract}
Mas o correio só entrou depois que o vereador Estima fez as placas das ruas. Aí aqui ficou nome de pássaro. Agora esse nome aqui da minha rua é do finado meu marido. O vereador Estima perguntou quem tinha sido os moradores mais velhos. Aí como ele sabia que eu era viúva, ele disse, Ó Dona Lourdes, o nome do seu marido vai o nome da rua. Eram duas ruas que iam ter nome de gente. A de cima, essa daqui não, a outra por trás dessa principal, que o senhor também morreu, mas não levaram a documentação, tinha que levar... do funeral né. Não levaram então não colocou o nome do senhor que morreu aí, que também foi morador antigo daqui. A mulher dele, ele morava com outra família, não sei como foi, eu nem conhecia ele, era Vera quem conhecia. Mas colocaram nome de pássaro mesmo. Só a minha que é João Bernardo. E ele foi quem colocou a placa, o vereador Estima, quando ele veio, ele mesmo foi quem colocou a placa de João Bernardo. Aí foi quando entrou o correio. Você acredita que as correspondências da gente ia pro Jd. Eliana porque a cunhada da minha filha morava lá, e ainda mora. Então a gente dava o endereço dela. Aí as cartas, nossas correspondências ia tudo ali pro Jd. Eliana.
\end{abstract}

A nomeação das ruas insere o bairro no serviço de correios com a definição de endereço e numeração das casas. A nova toponímia - Parque Residencial dos Lagos, fazendo a conjunção dos nomes dos três condomínios, mais uma vez, remete a um imaginário desejado de definição de um 
bairro único onde há a presença de muitos pássaros. E nessa designação, retoma-se a representação de um lugar em harmonia com os elementos naturais, os pássaros, a água.

Não obstante a atuação da associação de moradores junto a políticos locais assegurasse o início de alguns serviços, somente após a entrada do Poder Executivo Municipal é que a urbanização do bairro, paradoxalmente com remoções da margem, asseguraria a sua consolidação com a implementação da infraestrutura de água, esgoto, drenagem e pavimentação.

A ideia propagandeada na venda irregular dos lotes do suposto condomínio residencial acabou definindo um público inicial adepto a esse tipo urbanístico. O fato dos antigos moradores terem comprado um lote num condomínio fechado imputava uma diferenciação ao que se configurava no entorno: “ó, Pabreu, Montes Verdes, Jequirituba, a maioria do Recanto do Cocaia, Gaivotas, Cantinho do Céu é tudo invasão. O único lugar aqui que foi abençoado por Deus, que foi loteado e comprado e nós pagamos foi o nosso".

Além da diferenciação em relação aos bairros do entorno, notou-se, também, uma estigmatização interna ao bairro. Lucilene, ex-moradora do bairro (desde 1992), removida pela intervenção em 2009, comenta sobre o estigma de "invasor" que lhe fora atribuído pelos moradores "antigos" do bairro por ela morar na área destinada a "área verde do condomínio": "a gente comprou esse terreno, mas o pessoal chamava a gente de invasor, que a gente tinha invadido o terreno". Ressaltase aqui que tratarei sobre a remoção de Lucilene no item 3.5 do Capítulo 3.

Os moradores antigos do bairro comentam sobre a ocupação posterior da beira da represa, área que pela planta de venda dos lotes indicava "área verde":

\footnotetext{
V: Aí com o tempo que foi pegando essa beira da represa.

C: ...Foi pegando essas beira da represa, foi fazendo...

V: Mas os próprios moradores também vendiam. Eu conheço. Essa parte mesmo aqui ficou, filha. Isso aqui não foi loteado.

C: Não. Era pra ficar livre isso aqui. Foi tudo invadido.

- Mas vocês tem o projeto do loteamento aqui?

M: No mapa tem. Desculpa eu entrar no meio, quando nós compramos isso aqui que a gente foi fazer a transferência pro nosso nome, era ali onde tem o Pq São Paulo.

V: Ali pra cá um pouco da linha do trem.

M: Justamente, ali a pessoa lá mostrou pra nós. Essa área (indicando o parque), direitinho essa área, que chama-se área verde.

C: Tinha um mapazinho daqui. Tinha sim.
}

O tema da conversa lembrou-nos o que acontecera no Catumbi em relação aos moradores do morro, na Selva de Pedra em relação aos cruzadenzes e também em Winston Parva, uma comunidade periférica de uma cidade da Inglaterra, cujo processo foi analisado por Elias e Scotson, no final dos anos 
1960: a estigmatização de um grupo de moradores em relação a outro. Esse processo, resultante das relações de vizinhança, busca instituir sua identidade, só que com isso, opera a partir da depreciação do outro (ELIAS e SCOTSON, 2000). Assim, configurava-se no Residencial dos Lagos dois níveis de estigmatização: o primeiro em relação aos moradores dos bairros do entorno e o segundo, em relação aos moradores do próprio bairro - os que habitavam a beira da represa, área designada na planta de venda como área verde. De qualquer modo, os outros eram os invasores. E essa estigmatização interna também ganhou força com o projeto de urbanização, já que sua execução em etapas privilegiou o Lago Azul, adotando-o como início das obras. Assim, podemos marcar dois momentos do bairro que se apresentam claramente: antes e depois da intervenção realizada.

No entanto, antes mesmo das obras do parque estarem finalizadas, as redes de saneamento já começaram a dar problemas. O parque construído conjuga o espaço livre com os interceptores de saneamento das casas, conectando-as às estações elevatórias de esgoto, que são duas no bairro. Portanto, se há algum problema com a estação elevatória, o efluente retorna e extrapola nos poços de visita. Isso é muito recorrente no bairro e requer a presença da SABESP cotidianamente. Se a atuação de Dona Vera, como liderança comunitária, anteriormente era em busca de serviços urbanos, hoje, com a implementação da infraestrutura, sua pauta mudou. Sua experiência como representante do bairro no acompanhamento das obras acabou abrindo possibilidades de se tornar a responsável pelo parque. Vinculação essa, inclusive reforçada ao fim da gestão municipal em 2012: ela administrava o parque, gerindo uma equipe de jardineiros contratados pela construtora das obras. Quando terminou o contrato da licitação, antes ainda do final da gestão municipal em 2012, esse esquema de funcionamento foi descontinuado, alterando a condição de manutenção parque, que até a nova gestão municipal (2013) se organizar administrativamente, ficou sem manutenção.

De qualquer modo, Dona Vera, sendo paga ou não por cuidar do parque, é uma grande defensora do bairro e do parque, ainda se acostumando com a nova forma de atuação política:

Dona Vera: Eles acham que eu tenho que carregar o bairro nas costas... É tudo, eu tenho que resolver tudo... Agora mesmo a hora que eu cheguei a mulher chegou ali e falou pra mim: e aí Vera, você não vai limpar a praça aqui não? Você não tá vendo que tá tudo sujo? Eu falei: cadê os meninos? Os meninos não começaram a cortar a grama hoje? - Ai, eu não vi. Só sabe reclamar, entendeu? Não liga pra mim pra perguntar: Vera, você tá precisando de uma vassoura? Você tá precisando de qualquer coisa, um rastelo... Não! Sabe, você vai se estressando. Quando você vê apoio de um lado, apoio de outro você se anima. Mas quando você não vê. Você tá sozinha aí ó. 


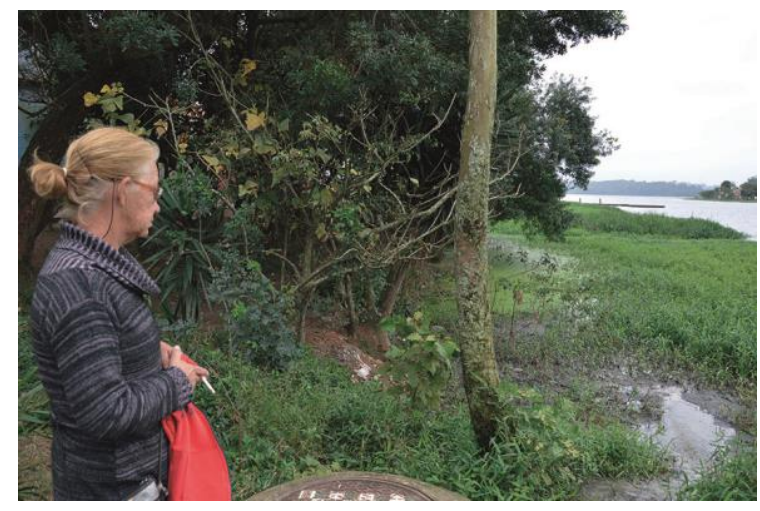

Figura 28 - Vera e vazamento de esgoto na rede da Sabesp. Crédito: Melissa Matsunaga, 2013.

\section{DONA LOURDES}

Aqui transformou minha filha. Quando eu trabalhei com a Vera, ela presidente e eu a vice, a gente saía por aí. O pessoal dizia: vai ter reforma lá. Pode ser que meus bisnetos vejam, porque eu não vou ver. Eu não acreditava... que quando começou, eu disse, mas olha, não é que eu vou ver, a reforma que vai ser aqui?

Dona Lourdes veio de Recife e tem 73 anos. É viúva há 23 anos e tem 9 filhos. Morou 5 anos no Jd. Miriam. Comprou o lote em 1987, construiu a casa aos finais de semana. Segundo a antiga moradora do bairro: não tinha luz, não tinha água, tanto que fez questão de me mostrar o poço e a fossa negra em sua casa. Dona Lourdes é uma das vivenciadoras mais idosas que entrevistei e a experiência de vida certamente traz um sentimento específico em relação ao passado na metrópole paulista. Suas elaborações são imbuídas de positividade, evidenciando um aspecto de satisfação ao que viveu e conquistou pelo bairro, já que muitas das melhorias ela atribui à sua atuação junto com Vera em articulação com o vereador e o administrador regional, cujo período que não soube precisar bem e do qual também não sente saudades porque "era muito cansativo".

Dona Lourdes mudou-se para São Paulo junto com o marido, já aposentado da rede ferroviária pernambucana em 1985, na trilha de um dos filhos. Este, já casado, veio com a esposa morar no Jd. Miriam junto ao sogro. "Segundo Dona Lourdes, foi ele quem trouxe nós pra aqui, pra São Paulo". Logo ficou sabendo pela vizinha: “Aí, Dona Lourdes, vamos ver se a senhora consegue um terreno lá onde eu comprei o meu. Aí a gente veio, pesquisou, e nós compramos esse terreno aqui. E aqui fomos construir”.

Ainda que não tivesse partilhado da dificuldade generalizada do bairro, já que os filhos sempre a ajudaram no suprimento de água e de alimentação, Dona Lourdes presenciou as mudanças pelas quais o bairro passou. Narra a disputa pela água num momento em que ainda não havia redes de abastecimento e a Sabesp atendia com caixas d'água instaladas na área onde se encontra a igreja católica no bairro hoje: 
Eu e a Vera nós batalhamos tanto pra entrar água aqui. Então a Sabesp foi e mandou uma caixa de não sei quantos mil litros de água. Colocou ali em cima, que não tinha igreja, não existia. E saiu até morte ali. Por causa de água, de um balde de água. Graças a Deus que eu nunca fui, porque meu menino sempre ele trazia do Eliana ou do Cocaia. Já tinha o [supermercado] Ricoy lá no Cocaia, ele é antigo, esses tudo é novo. Então quando os galão estava secando, ele já passava e já trazia. Eu nunca fui pegar água lá. E deu briga que teve morte. Um senhor que morava aqui nessa rua subindo, ele foi pegar um balde dágua, a mulher dele estava com sete meses de gravidez, esse que morreu, ele foi pegar o balde dágua mas tinha que estar lá na fila, e a mulher querendo colocar comida no fogo e nada dele chegar com a água. Ela vai, manda um sobrinho que ela tinha junto morando aí, disse: vai lá, fala pra teu tio trazer a água que eu tenho que botar o feijão no fogo. Ele foi e atravessou na frente do outro pra pegar o balde. Eu só sei que foi aquela discussão, o outro chegou em casa pegou o revolver, e foi pá, matou na hora. Na hora. $\mathrm{O}$ ano eu esqueço, mas isso já tá com uns 15 anos. Depois dessa morte isso deu em jornal deu em tudo. Daí foi que vieram e colocaram água pra nós, depois dessa morte.

As benfeitorias do bairro, em destaque a energia elétrica e a coleta de lixo, também são elucidadas a partir do envolvimento com os políticos locais:

A luz foi antes, muito antes da água... A luz até que não deu trabalho não. A luz veio mesmo por conta dos vereadores que estava querendo se candidatar, entendeu? E falava que aqui não tinha luz suficiente. Você ligava o chuveiro depois das sete, você tomava banho gelado. Porque caía. Aí foi que colocaram. Carro de lixo, conseguimos! É durmeteza desse povo pra não dizer semvergonhice. Sabe que o lixo é terça, quinta e sábado. É juntar direitinho e por no dia. Não é sem-vergonhice? Conseguimos olhe, carro de lixo, correio, água.

No entanto, apesar do contexto de precariedade ser semelhante, a atuação das lideranças da região era apartada. Segundo Dona Lourdes, não houve unificação da pauta em curso. E nota-se que até hoje, as “alianças” entre as lideranças são pouco frequentes, e quando ocorrem, há muita desconfiança em relação aos seus reais interesses, os quais são nitidamente vinculados a políticos distintos.

Aqui foi uma luta separada. A gente não lutou junto. Quem era do Cantinho do Céu era a Floripes. Porque lá era uma liderança, aqui era outra. Qualquer coisa a gente levava pro Enoque ou vereador Estima. E ele recebia a gente muito bem. Foi em 96... Não tinha correio, a gente conseguiu com vereador Estima. E o Enoque que fazia parte da administração da regional, então nós conseguimos correio, água, a luz já tinha, por ele também.

As dificuldades da vivência no passado também são lembradas por Dona Lourdes, quando a tecnologia da telefonia pública, através de ficha telefônica, já quase esquecida, e a indisponibilidade do serviço no bairro a faziam caminhar todo sábado ao Cocaia para ter notícias de um dos filhos: 
O meu menino que mora aqui nessa rua debaixo, ele estava no exército nessa época, eu ia lá na feira do sábado no Cocaia ligar pra ele porque na casa da noiva dele tinha telefone. Aí pra eu comunicar com eles eu ia lá na feira comprava dois, três cartão pra poder ligar, pra me comunicar com ele. Era ficha! Cartão foi depois! Era ficha! Lá ia eu com aquele saco de ficha! Sim senhora, ia eu todo sábado. Eu ligava pra saber como é que ele estava lá em Brasília. Por aqui a gente não tinha. Aí depois colocaram orelhão aqui no Pernambuco, na última que agora é uma igreja de crente, que ele alugou outro lugar ali na avenida e colocou o armazenzinho dele, as mercadorias dele. Colocaram orelhão aí, a raça quando passava à noite quebrava! Quando amanhecia o dia o telefone estava quebrado. Eles destruíam. Os próprios filhos dos moradores. Aí o Pernambuco ligava, lá vinha a Telesp arrumava. Era dois orelhão que tinha. Não passava oito dias funcionando. Quando pensava que não amanhecia o dia quebrado. Aí ele mandou arrancar. 'Não, não aguento mais essa zuada na minha cabeça' - que era o armazém dele e a casa em cima. 'Eu não aguento mais essa zuada à noite não'. Aí ligou, vieram e arrancaram.

É inevitável para Dona Lourdes a "valorização" do bairro, mas, para a antiga moradora, a valorização não diz respeito aos imóveis diretamente, mas sim, à ampliação da rede local de comércios e serviços, que melhorou com o passar do tempo:

Então nosso bairro aqui tá valorizado. Tem farmácia, tem padaria e tem mercado. Que não tinha nada, você ou comprava fora ou então tinha que ir lá no Cocaia. Se precisasse de uma caixa de fósforo, por aqui ninguém vendia nada. É tanta barraquinha como diz a história. Porque valorizou o bairro né?

Dona Lourdes destaca aspectos da dinâmica imobiliária local, onde os próprios adquirentes de lotes construíam ou ampliavam suas casas para alugar, e que ela nunca teve "ganância" para isso:

O Mineiro aí fez bastante casa, mas tudo assim. Alugava. Outros também. Aqui nessa rua, um bocado de gente também, fizeram aqueles quadradinhos e alugava. Feito aqui em casa, esse lote, aí fazia ali atrás e alugava. Em cima e alugava. E eu não quis isso. Eu não tenho ganância para aluguel. Porque aluguel dá dor de cabeça.

O caso do 'Mineiro' é enfatizado por Dona Lourdes, que comenta sobre a indenização das suas várias casas no bairro na ocasião das remoções: "O Mineiro aqui, que era família, genro, tudo dentro de casa. Ele comprou uma no Gaivotas, e com o dinheiro comprou um sitiozinho lá em Minas. Minha filha, eu creio que era umas 8 casas que tinha ali. Olha, ele vivia mais do aluguel".

Quando as obras no bairro começaram, Dona Lourdes ficou apreensiva sobre a possibilidade de sua remoção: "Quando falaram que ia derrubar. Eu falei, vão me dar algum dinheiro e eu compro em outro canto. Mas como não mexeram comigo... Que eu não queria sair também não. Eu acostumei aqui minha filha”. A sua permanência acabou incidindo também na sua crença de que o bairro ia melhorar, sentimento que ela mesma diz não ter fé: "eu não tinha fé, isso 
aqui é um lugar esquecido". E hoje, quando recebe amigos antigos ou parentes, que conheciam a anterior precariedade do bairro, comenta como eles ficam surpresos com a atual situação:

Quando vem amiga da gente lá do Jd. Miriam, ou ali em Suzano que morou uma família que morou com a gente lá no Jd. Miriam, que sempre eles vêm passear aqui: 'Ah, Lourdes, você tá morando agora é no centro mesmo, você tá morando é no Morumbi'. (risos) Porque antes quando vinha: 'Nossa, criatura, como é que tu mora aqui?' Eu digo: 'eu gosto daqui, um dia isso melhora'. - 'Melhora nada! Isso aqui não vai melhorar nunca'. Aí quando aparece agora: 'Mas Lourdes, você tá morando é no Morumbi. Pra você ver, eu não falei pra você que um dia melhorava'. Quer dizer, eu não tinha fé, eu não tinha fé não. Eu digo: isso aqui é um lugar esquecido.

A localização de sua residência acabou permitindo que ela presenciasse, desde o início, alguns conflitos de convivência que começou a se estabelecer no parque. Ao morar defronte à primeira parte dele, que foi inaugurada com a presença de campo de futebol e pista de skate, comenta sobre o "pancadão" que começou a acontecer à sua porta, inibido de modo violento pela polícia:

Sexta feira a gente não dormia porque dava oito da noite, começava carro de um lado, carro de outro. Cada um com seu som mais alto do que o outro. Estremecia! Três, quatro horas da manhã era que essas criatura ia embora. Aí começaram a chamar polícia, e a polícia foi vindo, foi chegando, foi chegando, foi metendo bomba de gás aí neles. E eles foi correndo, correndo. Olha, agora nem parece... Durante o dia você vê todo mundo brincando, jogando bola. Mesmo que fiquem jogando bola até tarde não tem problema. Mas o negócio era os carros de som. Toda sexta-feira a polícia chegava. A gente fechava tudo aqui pra poder assistir um pouquinho de televisão e quando dava os pipoco e o povo correndo, parecia um bocado de cavalo. Aí foram tomando consciência... Teve um pessoal aí que escutou o pessoal falar que vinha do Capão Redondo praqui. Vinha do Varginha praqui. Era um cabaré. Você sabe o que era um cabaré? Olha menina, quando era de manhã, era tanta garrafa de bebida quebrada, porque eles bebiam e quebravam. Era tanto vidro! A Vera ficava doidinha, coitada! Pra mandar os meninos limpar, os rapazes que trabalham. (...) Aí a polícia vinha, botava tudo pra correr e eles foram indo pra outro lugar. Durante o dia é essas criançada passeando que isso aí é bom e maravilhoso. O jogo de bola deles aí ninguém se incomoda. Ninguém dormia da sexta para o sábado. Não dormia! (risos) (...) Agora não, agora a gente dorme tranquilo... Ficam só assim, conversando... Mas a zuada não tem mais não. Não disputam mais que meu som é melhor que o outro não. Era funk. Nossa! Olha, pelo amor de Deus, amanhecia o dia com a cabeça doendo de tanta zuada. (...) Esse pátio aí ficava cheio, cheio de gente. Só para beber e fumar droga. Porque aqui no oitão aqui ficava o cara só passando droga. No oitão aqui da minha casa. Ficava aí na esquina... só passando droga. A droga tava comendo solta aqui dentro. 
O "pancadão", uma vez inibido nesse trecho do Parque (margem sul), começou a ser realizado em outro trecho (na margem norte), surgindo nos depoimentos de outros moradores do bairro, Seo Manoel e Seo Cunha, e será abordado no item seguinte "Quando a casa vira parque"59.

Hoje, Dona Lourdes faz parte de um grupo da $3^{a}$ idade, convivendo com outros idosos da região com quem realiza caminhadas "na terça e na quinta. Tá animado nosso grupo. Aí tem a enfermeira que acompanha. Tá vindo também uma turma do Cocaia, do Cantinho do Céu, tudo fazer caminhada aqui. É a terceira idade”.

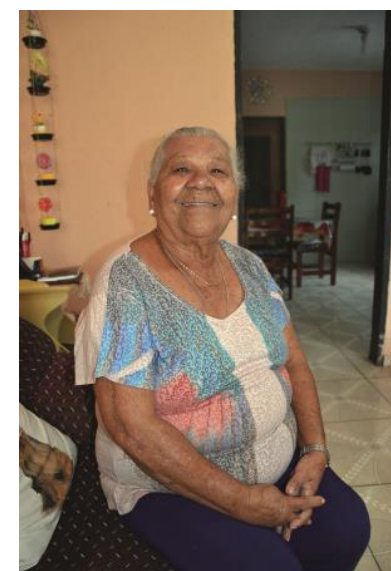

Figura 29 - Dona Lourdes em sua casa, 73 anos. Crédito: Melissa Matsunaga, 2013.

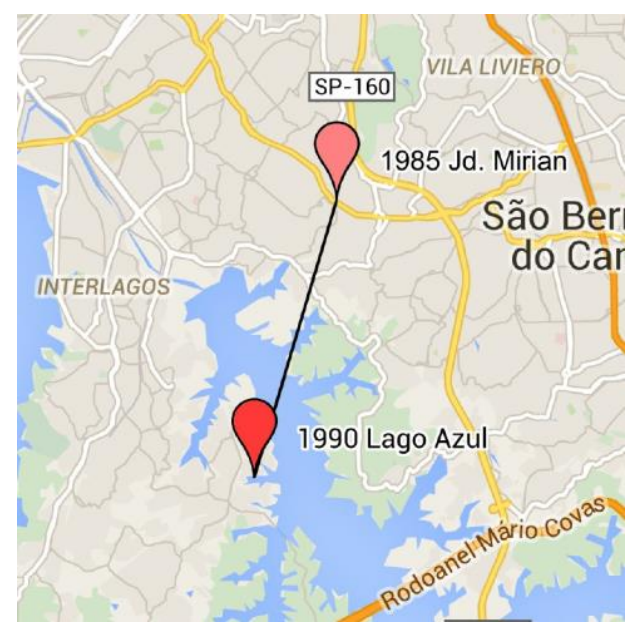

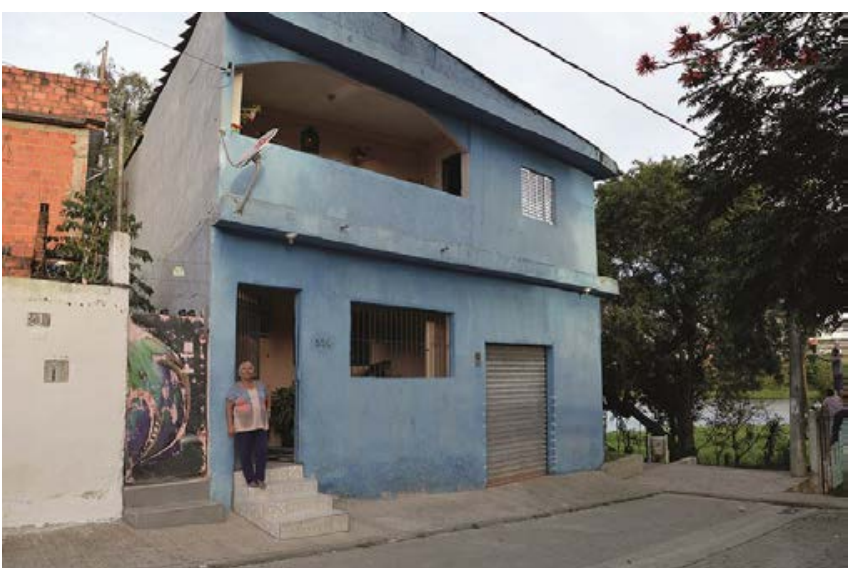

Figura 30 - Dona Lourdes em sua casa à Rua João Bernardo Mendonça, nome de seu falecido marido. Crédito: Melissa Matsunaga, 2013.

Figura 31 - Locais de moradia de Dona Lourdes.

${ }^{59}$ A manifestação cultural do "pancadão" no Lago Azul teve uma reativação no bojo dos "rolezinhos" acontecidos no final de 2013 e início de 2014 na cidade de São Paulo, quando adolescentes e jovens marcaram encontro, por meio de redes sociais, em shoppings reunindo milhares de pessoas. Alguns "rolezinhos" foram agendados no Lago Azul no início de 2014, convocando jovens a "encostar na humildade e disciplina". 


\subsection{QUANDO a CASA VIRA PARQUe}

O parque linear construído onde outrora era residência de muitas famílias do Lago Azul, teve grande impacto não apenas no cotidiano do bairro, mas, também, da região. Quando surgiu como equipamento de lazer, com promessas de se estender pela margem da Billings, a formar uma faixa de $7 \mathrm{~km}^{60}$ de comprimento, o trecho inicial do parque (1,5 km de extensão) suscitou vários tipos de opiniões dos moradores do Lago Azul, desde total aceitação do caráter de lazer e recreação da margem, até questionamentos quanto à sua necessidade num contexto de precariedade de outros equipamentos urbanos, como creches ou postos de saúde. No que concerne ao cotidiano do bairro, uma vez instaurado o parque, alguns conflitos emergiram, reforçando estigmas e acirrando processos de disputa locais.

Um dos conflitos encontrados diz respeito à questão toponímica do parque linear construído. Oficialmente denominado Parque Municipal Cantinho do Céu (Decreto Municipal nº. 53.380/2012) em meados de 2012, num momento de campanha eleitoral, as obras até aquele momento (primeiro trecho de seis a serem construídos) se restringia apenas ao bairro Parque Residencial dos Lagos. A desinformação gerou constrangimentos e revoltas, principalmente por moradores do Cantinho do Céu, que denunciavam a inexistência de qualquer parque ali' ${ }^{61}$.

Por outro lado, para os moradores consolidados do Residencial dos Lagos, o parque linear construído foi recebido com aceitação, apesar de alguns conflitos iniciais advindos do caráter público do espaço. A margem do Residencial dos Lagos, uma vez aberta, com a instituição do uso de lazer e recreação, possibilitou o engendramento de novos comportamentos e relação dos moradores com a margem. Ou seja, esse deslocamento - antes: casa, agora: parque - potencializou o uso público da margem, antes particularizado/privatizado pelas moradias.

A implementação de infraestrutura no bairro e definição de espaços de lazer e recreação na margem da represa, interferiu em sua paisagem, anteriormente ocupada por moradias. A "presença" do Estado materializada nas obras das redes de infraestrutura urbana trouxe novos sentimentos dos moradores em relação ao lugar do bairro na configuração da região. As casas que foram consolidadas receberam reformas e ampliações.

${ }^{60}$ BOLDARINI, Marcos. Entre a casa e a água. In.: BARDA e FRANÇA. Entre o céu e a água (2012:29).

61 No ano eleitoral de 2012, imagens das obras em curso no bairro, enfatizando o parque construído, tomaram espaço no horário político-partidário. $O$ vídeo "O Cantinho do Céu que não está na TV" - gravado e editado entre julho e agosto de 2012 pelo coletivo Rede Extremo Sul e moradores do bairro - dentre outros aspectos, colhe depoimentos, registra as memórias e demonstra 0 posicionamento dos moradores diante da propaganda eleitoral na TV, no intuito de rebater a informação de um parque construído no Cantinho do Céu. Disponível em http://vimeo.com/47882646. Acesso em 14 jan 2015. 


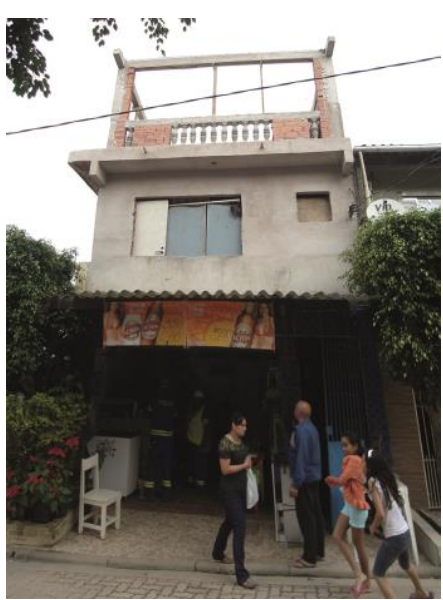

Figura 32- Ampliação da residência e comércio lindeiro ao parque. Crédito: Melissa Matsunaga, 2013.

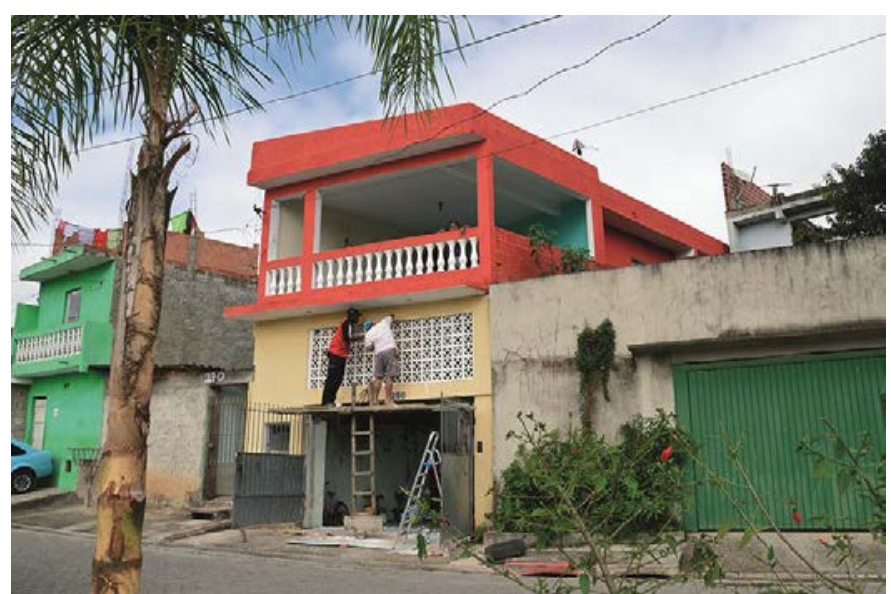

Figura 33 - Reforma e pintura de residência em frente ao parque. Crédito: Melissa Matsunaga, 2013.

Um antigo morador fala sobre essas transformações que o bairro passou e como as obras não só de infraestrutura urbana, como a realização do parque tornou seu sentimento de tristeza em um recatado orgulho:

- Quando a gente mudou pra cá em 89 era triste. Nós não tínhamos água, não tínhamos luz, não tínhamos esgoto, não tínhamos telefone, não tínhamos nada. Pra começo, só tinha a rua, mas nem a estrada estava pronta ainda, era só a vereda. Então o material [de construção] o caminhão deixava lá em cima (indicando o mercadinho localizado antes do linhão). A gente carregava no carrinho de mão lá pra baixo. Era muito triste aqui viu. Não tinha infraestrutura nenhuma, não tinha benefício nenhum aqui.

- Mas quando o Sr. comprou em 88, falaram que ia ter?

- Falaram que a luz ia ter, como teve. Três meses pra frente eles colocaram o posteamento na rua então já teve iluminação. Não pública! A gente puxava pra casa né. $\mathrm{E}$ água, minha filha, demorou 5 anos pra chegar. Quando chegou a água chegou rede de esgoto junto né. Aí pronto, aí foi entrando os benefícios aí até que entrou essa graça de Deus aí.

- O que é a graça de Deus?

- Toda essa obra que foi feita. Eu não sei se você teve a oportunidade de andar depois da igreja pra ver que coisa linda: nós temos um píer aí, na frente aí (indicando a direção), pra nós tomar banho. É uma mini praia. Eu vendo sorvete lá. Então hoje tá uma maravilha. Visto o que era, hoje tá o céu. Hoje tem asfalto, tem água, tem luz, telefone, esgoto, internet, ônibus. O ônibus é só na parte da manhã, por quê? Por que só vai ficar definitivo o dia todo quando terminar a obra da Belmira. Daí sim, o dia todo.

Para o caminhante da margem, o percurso linear proporcionado pelo projeto do parque (Figura 34) revela uma série de possibilidades de uso, com espaços de brincar, de jogar futebol, jogar vôlei, andar de skate, além de abrigar vários espaços para contemplar o entorno. Ao mesmo tempo em que lança o olhar sobre o outro, as vistas permitem a reflexão sobre si mesmo e os processos que o bairro ao longo do tempo passou: a vista a leste (São Bernardo do Campo) é de mata, remetendo a um imaginário de preservação ou natureza, mata nativa, floresta; a vista ao sul 
encontra o Jd. Prainha, que está passando pelas mesmas intervenções urbanísticas; e a vista a norte dialoga com o Cantinho do Céu, onde aparentemente a situação permanece a mesma, ou seja, sem obras, sem redes, com as moradias, quase pisando na água algumas vezes.

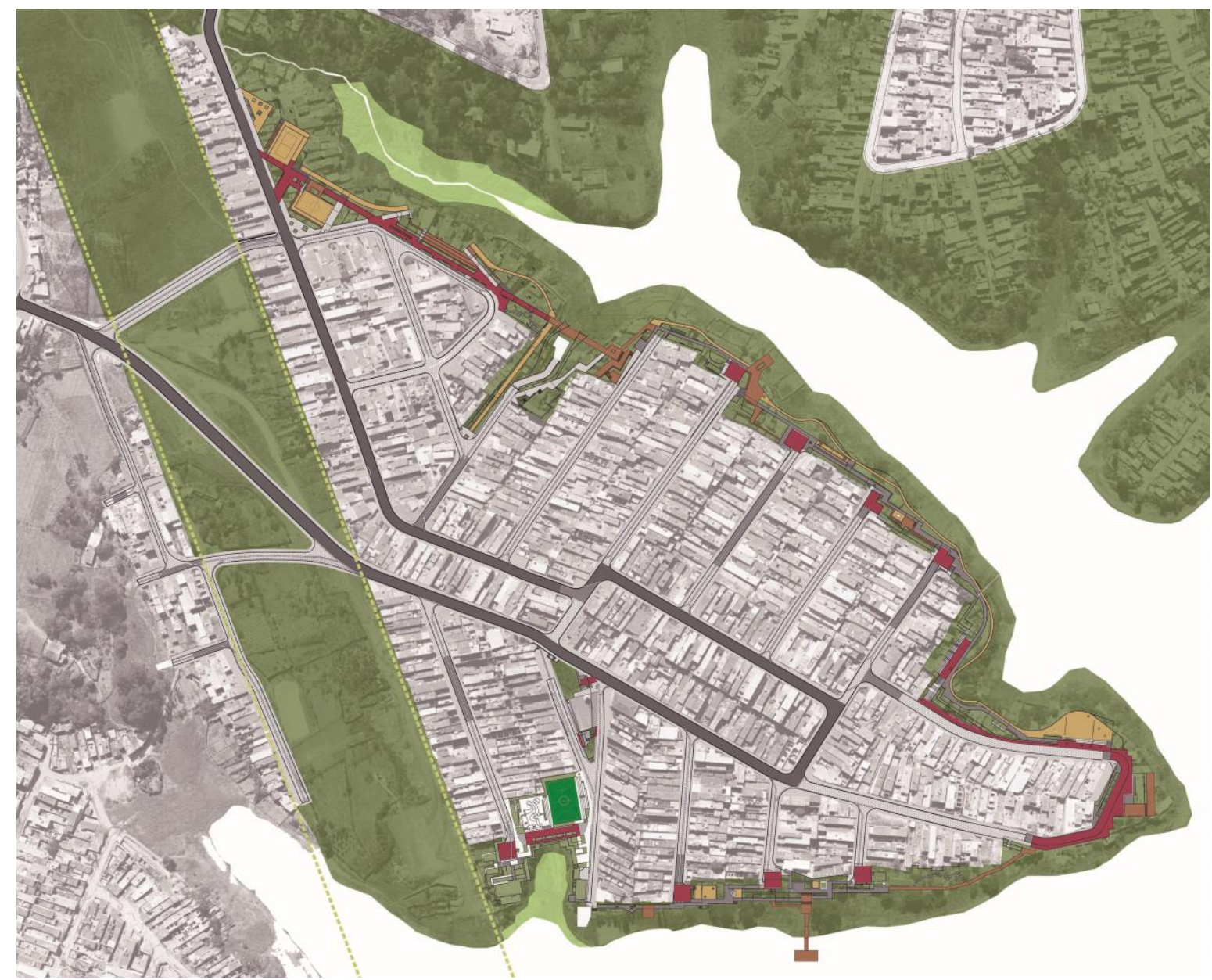

Figura 34 - Implantação do Projeto Executivo de Paisagismo do Complexo Cantinho do Céu. Parque Trecho 1 - Residencial dos Lagos. Fonte: Boldarini Arquitetura e Urbanismo.

O ponto de concentração na margem sul é um deck de madeira flutuante que aproxima o caminhante da água, tornando-se um dos pontos mais movimentados aos fins de semana, com muitas crianças tomando banho e sol. A pintura realizada nas empenas cegas das casas estabelece a fronteira entre o privado doméstico e o público de lazer e recreação. Aos poucos, o grafismo abstrato vai dando lugar a grafites e algumas pichações. Além disso, com a iluminação, o parque também é frequentado à noite. Na margem norte, o ponto de destaque é o "arco", escultura em material tubular metálico, que é utilizado como ponto de encontro, além de sustentar uma tela para projeção de vídeos, uma vez que conta com uma arquibancada e um mecanismo para apagar as luzes dos postes próximos.

A vegetação é tímida, como se estivesse desconfiada sobre a sua permanência num local tão disputado. As árvores de grande porte que existem - eucalipto, jaqueira, aroeira, fícus - são as que 
resistiram ao processo de remoção junto a tratores e caçambas. O projeto do parque especificou algumas que não vingaram ou que estão se desenvolvendo a passos lentos. Já o mato, esse é preponderante e até não surpreende o seu desenvolvimento, as condições ideais para sua existência estão ali. Eles se misturam ao brejo ao aproximar-se da água, como se quisesse formar um tapete de algas.

Os grafites e algumas pichações também tomam lugar nas muretas e arquibancadas, demarcando a apropriação do parque pelos diversos grupos. A pista de skate é o ponto onde isso é mais notado, sendo quase que constantemente regrafitado, de acordo com os eventos agendados pelos grupos e coletivos culturais, como veremos adiante.

O uso que é intensificado aos fins de semana, não salvou o parque da falta de manutenção. O tempo auxiliou nesse processo, visto que as lixeiras enferrujaram, o mato cresceu e algumas lâmpadas não acendem mais. Sem falar nos poços de visita da rede de esgoto que sempre dão problema, deixando escapar o efluente que contamina o ar e, principalmente, a água da represa.

Alguns depoimentos de vivenciadores ilustram as apropriações e conflitos no uso do espaço público.

Seo Cunha e Seo Manoel são amigos e vizinhos. Moram na Rua Falcão Negro desde 1988 e já eram amigos antes de se mudarem para o bairro: "Somos uns pernambucanos, somos de uma área só em Pernambuco. E somos muito amigos". Seo Cunha tem 56 anos e morava antes de aluguel no bairro Reimberg, que, segundo ele, fica depois da garagem da empresa de ônibus Bola Branca, próximo ao circo-escola. Seo Cunha é casado, tem quatro filhos e "um punhado de netos".

C: Na época que eu comprei já peguei loteado. Quadra tal, número tal e por aí se foram. Não tinha nada de energia. Não tinha água, era um sufoco. Não tinha água encanada, não tinha mesmo. Depois foi se passando o tempo e daí veio vindo as benfeitorias né. Aí veio o nome das ruas que também não tinha. Aí veio luz... A luz foi o primeiro, depois a água. Aí depois já entrou o correio e por assim foi.

Seo Manoel tem 67 anos e é mestre de obras aposentado "mas eu mexo com qualquer coisa. Eu fui servente, eu fui ajudante, fui oficial e hoje eu to aqui, aposentado, graças a Deus". Seo Manoel tem duas filhas já "criadas" e um menino, que "dizem que é dele". Hoje Seo Manoel é solteiro e suas duas ex-esposas moram no mesmo lote da sua casa, "uma em cima, e a outra embaixo", a ele mesmo cabe um quartinho separado. No entanto, diz ele viver "mais no mundo, em viagens pro norte, Aracaju, Itabaiana, Mato Grosso”. Algumas dessas viagens são a trabalho, onde acompanha algumas obras e outras são de visita a parentes. 
Seo Manoel: Eu viajo bastante. Pra você ver, se Deus quiser, agora sábado ou domingo eu vou pra Itabaiana, no Nordeste. Pego ônibus aqui, é 4, 3 dias de viagem. Daí fico lá 15 dias, um mês. Volto pra cá de novo. Isso é muito bom pra pessoas que são idosas, você sabe, viajar, conhecer outros lugares que não pode conhecer. Então o que eu faço é isso. Se tiver algum serviço a gente faz. Chega lá, vamos rebocar essa casa? Vamos. Vamos fazer uma casa aqui? Vamos.

Os dois amigos de longa data, por morarem com a família em frente ao parque linear, na margem norte do bairro, se preocupam com sua manutenção e diante das diversas convivências do espaço público, tentam impor suas condições de moradores do local, Seo Manoel principalmente:

Seo Manoel: Só tenho a reclamar, assim, por exemplo, isso aqui, tão lindo mas tá abandonado. A molecada fica aqui bagunçando, quebrando tudo, quer dizer, destruindo, isso aí a gente fica triste. Tinha que ter alguém no mínimo pra tomar conta. Mas assim, pessoa permanente aqui no local, opa, sai um, fica outro. À noite, de dia, pelo seguinte, a molecada não tá nem aí, não quer saber, não custou nada pra ninguém, quer dizer, pra eles né? Se eu vejo nego danificando, eu não deixo, eu grito com o cabra na hora: opa, some daí rapá! Você não vai danificar, eu não deixo, você não vai quebrar nada! Certo, senão eu chamo a polícia pra ele na hora, ele vai ter que sumir, não adianta. E uma coisa que veio e nós não deixamos criar, foi o pancadão! Eles vieram aqui, ligaram o som, daí eu e ele aí: Pode parar! Mas aqui é público. É público pra você usar com respeito. Tem uma pessoa especial aqui ó, nesse portão branco, já pensou, meia-noite... Então é o seguinte, nós temos que dar o respeito, impor, impor, falar não vai fazer, não vai e acabou. (...) Tem outra coisa aqui que precisa ser resolvido: é esse monte de sujeira que a gente tem aqui na beira da pista. Meu, os caras pegam carrinho e é assim, olha, o dia todo, de entulho. Nós precisamos ter aqui uma pessoas que fossem, vamos supor, autoridade, que mandasse, à paisana, não viesse com carro, carro público, carro da polícia, entendeu? Não, viessem à paisana. Pra pesquisar e pegar.

$\mathrm{O}$ abandono do parque, naquele momento, representava perigo para as famílias pela presença do tráfico de drogas, como também possibilidade de roubos e assaltos:

Seo Manoel: Nosso bairro não tinha biqueira, ladrão não crescia aqui não, crescia? Começava, mas não ficava. Como que nós vamos deixar o cara montar uma biqueira aqui? Nós temos mulher, tem filho. A gente trabalha, sai $4 \mathrm{~h}$ da manhã. Esse aí a mulher dele tem quatro, cinco que ela cuida. Aí sai o menino pra escola, sai a outra menina pra escola. Fica difícil!

Ademais, o entendimento de que "o parque é uma biqueira" também é tido por alguns jovens moradores da região. Em oficina de mapeamento realizada entre abril e maio de 2014 com alunos da EE Maria Luiza, o parque não representa um espaço de lazer, muito pelo contrário, é visto como ponto de venda e consumo de drogas, o que faz com que frequentem o local muito raramente. 
Desde que foi instituído por Decreto Municipal em agosto de 2012, sua gestão é de responsabilidade da Secretaria Municipal do Verde e Meio Ambiente (SVMA), cuja demora na organização e consecução do processo licitatório de terceirização das ações de manejo, conservação e vigilância, ocasionou a ociosidade de um módulo habitável (container) instalado para a futura administração, além do crescimento da vegetação e lixo ao longo dos passeios.

Uma vez vazio, sem uso pela SVMA, esse container que contava com uma sala e um anexo com dois sanitários, teve sua arquitetura desmontada, sendo subtraídas as peças sanitárias, os vitrôs, as torneiras, além de ser alvo de pichações. O espaço abandonado simbolizava a ausência da manutenção e o esquecimento desse equipamento público pelo Estado. As reclamações quanto a não utilização pela prefeitura foram recorrentes durante a presença em campo, já que instaurava insegurança para os moradores: "Isso apoia o cara tocaiar quem vai sair de casa para roubar o carro, entendeu? A pessoa chega de noite, eu tenho um carro, minha filha tem carro, chega de noite o cara tá ali, antes dela abrir o portão o cara chega e leva porque não dá tempo. Outra, ela não pode reagir".

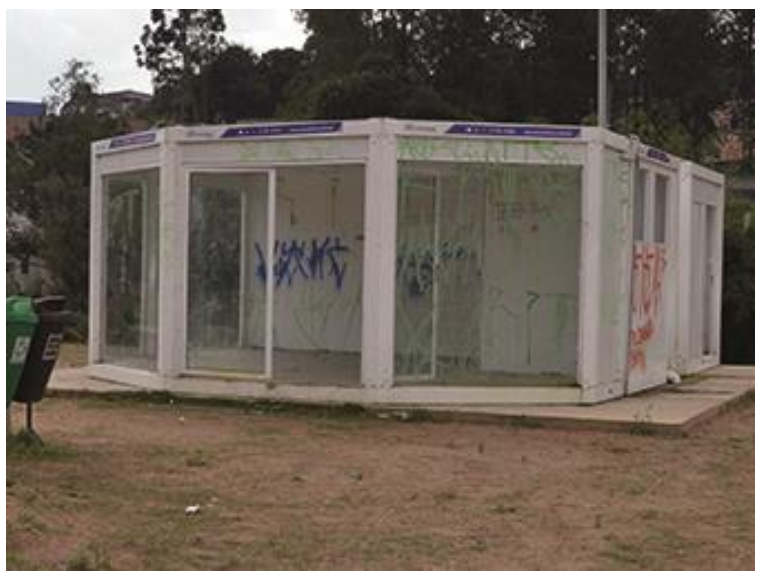

Figura 35 - Container instalado pela SVMA e abandonado, em maio de 2013. Crédito: Melissa Matsunaga, 2013.

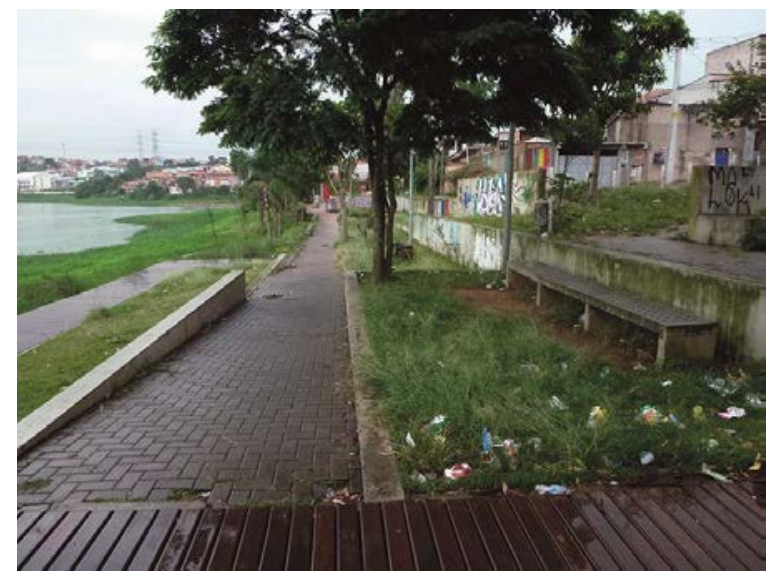

Figura 36 - Trecho sem manutenção com acúmulo de lixo, em fevereiro de 2014. Crédito: Melissa Matsunaga, 2014.

Jacobs (1961/2013:97) propõe considerar os parques de bairro como locais carentes que precisam das pessoas thes atribuindo utilidade, fazendo deles um sucesso ou em sua recusa, os condenando ao fracasso. O relato fotográfico realizado nas visitas a campo auxilia no processo que o parque, como espaço público, tem passado (Figura 35 e Figura 36). Se num primeiro momento a definição da margem coletiva foi positiva, por outro lado, a falta de manutenção do espaço público levou a apropriações de grupos não desejados, como usuários de drogas ou possíveis bandidos.

O espaço abandonado potencializou a ocupação de um grupo de jovens autodenominadoOcupação Comunitária Alternativa (O.C.A.). A ausência do uso e ocupação do container instalado 
pela SVMA, inicialmente pensado como espaço de administração do parque, tornou o espaço propenso a qualquer tipo de uso, principalmente o ilegal. Em contraposição a essa apropriação entendida como negativa, o coletivo de jovens ocupou o espaço, apropriando-se da infraestrutura e atribuindo um uso cultural para o container abandonado. Nessa perspectiva, a ressignificação do container por uma "organização comunitária alternativa” é um aspecto que vale ressaltar. Tim, organizador do coletivo O.C.A. e integrante do Imargem, comenta sobre a "ocupação" pelo coletivo, em resposta à "tensão" configurada pelo abandono da estrutura:

A galera começou a ocupar uma casinha que talvez era o lugar mais tenso. Uma casinha que era possivelmente para ser uma administração e aí a gota dágua foi que aquilo ali estava virando um lugar pra tudo. Era banheiro, drogômetro, motel, lugar para guardar roubo, até as pessoas ficavam com medo, os moradores, de estupro, essas coisas assim. Era um lugar que oferece risco. Já estava bem capenga, daí a galera começou a destruir mais ainda e ao mesmo tempo oferecia uma infraestrutura mínima.

O container tornou-se, em pouco tempo, uma infraestrutura mínima demais, já que o O.C.A. começou a tomar o espaço do parque. O arco se configura hoje como um dos principais pontos de encontro desse coletivo. Sexta-feira à noite há a exposição de um filme ou vídeo (Ver Figura 37), cuja programação é definida coletivamente a partir da troca de informações por rede social. Fifo, um dos organizadores do coletivo e morador do bairro Cantinho do Céu, relata como a apropriação dos espaços do parque tem sido feita pelo coletivo:

\footnotetext{
Nós, como coletivo, achamos sensacional esse espaço. Porque se não tivesse isso a gente até poderia fazer uma coisa similar, mas não parecida né. (...) Se não tivesse o arco, se não tivesse as arquibancadas, vários lugares... a pista de skate também foi uma coisa muito importante, pra criançada, quadra poliesportiva, quadra de areia, quadra sintética... como o parque é grande, tem que ter variedades!
}

A pista de skate, à margem sul do bairro, tem sido utilizada pelo coletivo Oficina Movimento Cultural, reunindo skatistas e MC's que tem promovido diversas atividades e campeonatos de skate no local.

Convém destacar que o coletivo O.C.A. não foi formado a partir da degradação do parque ou do abandono da estrutura do container. As atividades culturais já eram realizadas na região e o espaço abandonado suscitou sua ocupação, formalizando o grupo já em atividade. E o mesmo se coloca para os demais coletivos que se apropriam do parque para realizar suas atividades, que antes mesmo do parque, já eram organizadas e realizadas em outros espaços da região. 


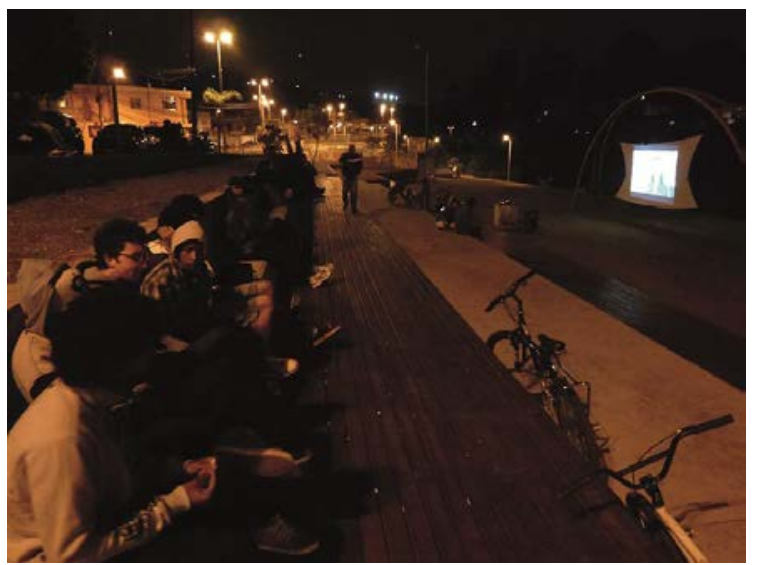

Figura 37 - Cine OCA - 29/08/2014 - Exibição do documentário sobre as APAs. Crédito: Melissa Matsunaga, 2014.

Mudanças na condução da administração do Parque a partir de agosto de 2014 indicam possíveis melhoras na conservação do parque como bem público municipal. Foi convocada a primeira eleição para o Conselho Gestor do Parque no dia 06 de setembro, cujo pleito foi o que mais mobilizou votos na história da SVMA, segundo o novo administrador, Vinicius Almeida, com mais de quinhentos votos. No entanto, o coletivo não disputou cadeira. A postura do coletivo nos espaços de representação política institucionalizados é problematizada por Tim:

- Teve recentemente a eleição do conselho gestor do parque, vocês resolveram não participar?

Tim: Não foi que não resolvemos, foi pouco tempo e pouca articulação da gente mesmo. E não posso culpá-los porque não fiquei sabendo de uma divulgação e de uma mobilização que faça as pessoas entenderem que isso é importante também. As pessoas criam vários conselhos, fóruns, mas as pessoas não sabem como participar e quando vai participar... Inclusive um parceiro foi participar e sentiu um clima de politicagem, um clima disputado. A gente tem a referência dessa eleição né... mas, é parecido: essa comunicação, como a lógica é organizada, quais são os interesses. Então dá uma certa brochada de participar desses espaços. Mas eu entendo, a galera não foi, não participou, daí vai querer reclamar como né.

O relato aqui descrito possibilita uma incipiente leitura em relação ao parque, relacionando seus usos e apropriações e tem o intuito de indicar aberturas desse momento do campo, dentre as várias outras possíveis. A leitura que se coloca é: pelos acontecimentos no Lago Azul, ao se constituir a margem da represa com o parque, o que se configura não é apenas a alteração de uso: antes casa, agora parque, resgatando o uso de lazer que existia inicialmente pela proximidade da represa. A alteração principal é que se, originariamente desde a formação das represas, esse uso de lazer estava vinculado ao privado a partir do parcelamento em chácaras de recreio de caráter elitizado, o parque institui o espaço público, fazendo emergir conflitos e disputas inerentes aos espaços públicos abertos enquanto lugar de trocas e convívio. Ao mesmo tempo, as famílias e as casas removidas, ao serem substituídas, coloca um novo tempo para o bairro, onde sua história e sua retomada através de lembranças, adquire uma forte dimensão simbólica e talvez 
ideológica. Isso ocorre não apenas porque alguns de seus ocupantes não estão mais presentes, ou porque também não há vestígios materiais que indiquem a sua existência anterior ali. Mas, principalmente porque este passado só é possível desde então pelo procedimento de elaboração da memória de seus moradores mais antigos que continuam morando no bairro e que presenciaram essa fase anterior. O que, com a ordem do tempo, tende a cair no esquecimento.

\subsection{TRABALHAR LIDERANDO OU LIDERAR TRABALHANDO}

Não é objetivo discutir a fundo as práticas de representação política, contudo, esse aspecto é imbricado aos discursos mobilizados pelas lideranças e se relacionam profundamente ao histórico dos próprios bairros, que desde sua origem vinculou as melhorias urbanas à ação de políticos locais. Assim, nos bairros estudados o que se percebe é que, desde sua origem, atuar como liderança comunitária é um trabalho. E nesse caso específico dos bairros Cantinho do Céu e Lago Azul, solicitado por outros agentes políticos, como vereadores ou deputados, ou até mesmo, funcionários da esfera executiva, o que se notou é que algumas vezes esse trabalho é pago, principalmente em épocas de eleição. Apesar disso, a militância é uma característica presente, ou seja, de defesa de direitos das famílias num contexto de precariedade urbana, na busca por soluções para os problemas cotidianos ou a execução de serviços urbanos para o bairro: desde cesta básica para um problema emergencial até a infraestrutura de abastecimento de água, correio e coleta de lixo.

A partir do momento em que as lideranças se estabelecem no bairro, há a configuração, portanto, de dois grupos distintos: o primeiro, em relação à rede de lideranças que atuam junto a determinado agente político, sem unificação das pautas; e o segundo, em relação ao conjunto de moradores dos respectivos bairros. Essa "trama", então configurada, reforça o entendimento de que a partir da ação da liderança em articulação com os políticos, as melhorias no bairro foram conquistadas. Assim, o que se nota e os moradores tem total esclarecimento quanto a isso é de que tal liderança trabalha para o deputado $\mathrm{x}$ ou vereador $\mathrm{y}$. E que devido a essa conjuntura local, há a permanência de um imaginário (real) de que, portanto, deputado $\mathrm{x}$ ou vereador y seja responsável pelas diversas intervenções urbanas em curso, reafirmado pelo uso político propagandeado em suas campanhas. Como afirmação dessa conduta local, durante a pesquisa de campo, surgiam indagações de quem seria o político responsável pelas obras em curso. Não raro na região, encontram-se faixas em agradecimento aos deputados e vereadores por alguma obra executada. 


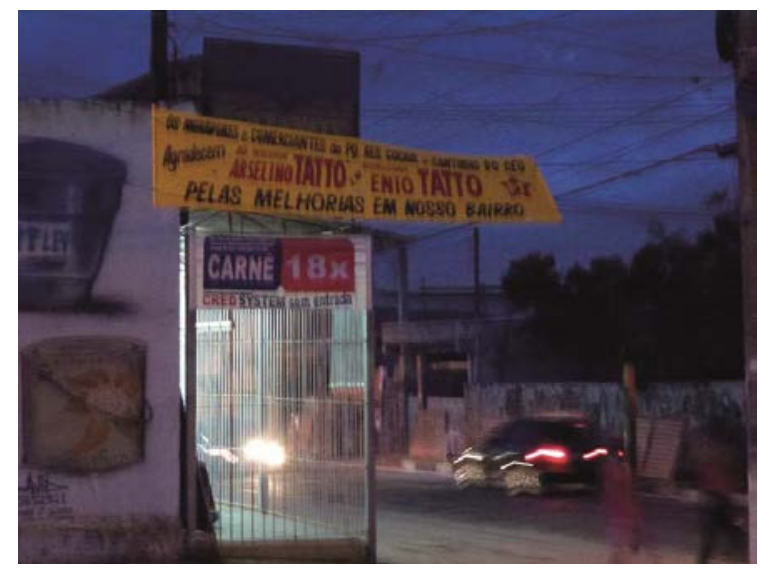

Figura 38 - Faixa em agradecimento a políticos locais na esquina das ruas Pedro Escobar e Mâncio Lima após obras de recapeamento asfáltico, abril de 2014. Crédito: Melissa Matsunaga, 2014.

Do ponto de vista das lideranças, entretanto, o que se nota hoje é o questionamento em relação a sua própria atuação e o não reconhecimento por parte dos moradores. No Cantinho do Céu, ainda com lutas a serem enfrentadas, como a UBS prometida e que ainda não é uma realidade ${ }^{62}$. No Lago Azul, a liderança, em comprometimento à obra realizada, acabou por se tornar uma guardiã do parque linear, desde que seja paga por isso, obviamente. E isso não é dito aqui de maneira cínica ou irônica, já que parte-se do pressuposto de que atuar como liderança é um trabalho.

${ }^{62}$ A UBS reivindicada para o bairro do Cantinho do Céu é uma demanda não apenas do Cantinho, mas também do Cocaia, já que sobrecarrega 0 atendimento da UBS mais próxima que é esta. As lideranças do Recanto Cocaia e suas práticas políticas residiu no objeto de pesquisa de mestrado de Laís Silveira finalizado em 2014. Ver Silveira (2014). 


\section{CAPÍTULO 03}

\section{O QUE NOS (RE)MOVE}

O presente capítulo aborda narrativas de vivenciadores cujas experiências foram agrupadas em torno do tema remoção. Essa temática permeia toda a história dos assentamentos precários irregulares - não só em áreas de mananciais -, e para quem vive em tal condição urbana é uma preocupação cotidiana em relação aos rumos que sua vida pode tomar. Essa ameaça constante varia de acordo com a política implementada frente à resolução do conflito e, no caso do Complexo Cantinho do Céu, esse deslocamento forçado aproximou-se de sua concretização com a instauração da Ação Civil Pública em meados de 1997, como visto no Capítulo 1. Desde esse período, mesmo com a expectativa da consolidação através da elaboração de estudos e negociação com o Ministério Público, cada um dos moradores só terá certeza sobre os efeitos do projeto em sua vida quando a equipe social "entrar em campo".

Inicialmente, para tratar o tema das remoções, é necessário resgatar, ainda que sucintamente, em que momento essa ação surge no âmbito das políticas públicas urbanas. Nessa recuperação histórica, as ações de desfavelamento na cidade do Rio de Janeiro, no início do século XX, marcariam a ação pública no combate aos cortiços, e o engendramento de um campo de disputa simbólica relacionado não apenas às favelas enquanto espaço estigmatizado, mas, também, às ações relacionadas a essa categoria (ações de "desfavelamento" ou consolidação). Sobre o Rio de Janeiro, Licia Valladares problematiza o debate acerca das favelas colocado no campo dos estudos sociais e, segundo a autora, a favela foi historicamente associada ao local da pobreza, instaurando "dogmas"63 que permanecem não apenas no âmbito das políticas implementadas, como, também, pelas próprias pesquisas que analisam o fenômeno. No caso de São Paulo, a questão das habitações da população pobre se configuraria a partir do modelo de urbanização periférico que teria sua expressão nos loteamentos periféricos sem infraestrutura (BONDUKI, 1998).

Ao longo do tempo, não apenas os estudos mas também as políticas implementadas em relação às favelas sofreram transformações. Segundo Bueno (2000), as políticas de intervenção nos

\footnotetext{
${ }^{63}$ Conforme Valladares (2005:148-152), são três os dogmas enunciados: (1) a especificidade da favela, marcada principalmente por um modo de vida cotidiano, de modo a instituir sua identidade própria (2) local da pobreza, demarcando o território onde os pobres moram, e assim a imagem dos favelados associada à imagem da favela como enclave incidiria num círculo vicioso de que pobreza geraria pobreza, sem perceber a estigmatização presente nessa representação e (3) a unidade, ao gerar uma categoria favela, ocultando assim a diferenças internas e a pluralidade de redes sociais existentes.
} 
chamados assentamentos informais ${ }^{64}$ (que englobam as favelas, além dos loteamentos clandestinos e irregulares) contemplam desde remoções completas, também conhecidas como desfavelamento ou erradicação de favelas, até ações no sentido de garantir a permanência da população - ou parte dela provendo melhorias na infraestrutura urbana destas áreas, através das ações de urbanização ou reurbanização. Essas ações não podem ser entendidas apenas no âmbito de cada intervenção, e sim na contextualização de processos em disputa mais amplos, como interesses econômicos e imobiliários.

Diferentemente do histórico carioca, que desde os anos 1960 já apresentava experiências de urbanização de favelas ${ }^{65}$, ainda que a contrapelo das remoções em curso, o caso paulistano vai ser marcado a partir das ações de urbanização de favelas da gestão Erundina em favelas localizadas à beira de cursos d'água nos anos 1990. A experiência acabou engendrando para a política pública habitacional paulistana grandes avanços, contribuindo na elaboração de uma alternativa à situação de moradia dessas famílias - com o reconhecimento desses territórios já habitados buscando sua reabilitação física - e também no enfrentamento do déficit habitacional, cujos índices englobam coabitação e falta de infraestrutura.

A urbanização de favelas surge com o objetivo claro de consolidação do assentamento precário existente, em contraposição à sua remoção, que é fortemente combatida. Quando surge no Rio de Janeiro como uma "alternativa" para os residentes ameaçados de remoção no período ditatorial, a urbanização, desde então, se constituiu como uma bandeira de luta através da qual já se buscava assegurar a função social da propriedade. Função reconhecida pela Constituição Federal de 1988 em seus Arts. 182 e 183 e mais recentemente com a instituição da moradia com um direito social constitucional66, em seu Art. $6^{\circ}$. O campo dos estudos urbanos e o fortalecimento dos movimentos sociais de moradia na década 1980 contribuíram no entendimento de que a urbanização de favelas traduz o reconhecimento não apenas da função social da cidade, entretanto, também da propriedade, reconhecendo sua inserção no tecido urbano. No entanto, apesar dos avanços, os diversos e aprofundados estudos nessa área reforçam o entendimento de que a urbanização de favelas é

\footnotetext{
${ }^{64}$ Para designar tais assentamentos atualmente há o termo assentamentos precários cunhado pela Política Nacional de Habitação em 2004.

${ }^{65}$ A urbanização de Brás de Pina, na zona norte do Rio de Janeiro em 1968, é considerada um marco no histórico de urbanizações de favela no Brasil, principalmente pelo envolvimento dos arquitetos com os moradores, estabelecendo para tanto um projeto in loco.

660 Art. $6^{\circ}$ da Constituição Federal de 1988 foi alterado por Emenda Constitucional $n^{\circ} .26$ de 14 de fevereiro de 2000, incluindo a moradia como direito social constitucional, a nova redação: Art. $6^{0}$. "São direitos sociais a educação, a saúde, 0 trabalho, a moradia, 0 lazer, a segurança, a previdência social, a proteção à maternidade e à infância, a assistência aos desamparados, na forma desta Constituição".
} 
insuficiente para solucionar a questão habitacional, no sentido de que vem em seguida à ocupação do solo, e não a antecedendo. Enquanto não houver política pública urbana e habitacional de longo prazo, a urbanização dos assentamentos precários constitui-se como medida paliativa frente ao problema historicamente constituído no país de acesso formal à terra.

Dentro dessa temática, o que interessa problematizar no presente estudo é a atualização da ação de urbanização de assentamentos precários - não somente favelas - no contexto urbano estudado.

Como exemplo incidente na região de mananciais, temos ainda nos anos 1990, em contraposição à experiência do Programa Guarapiranga, com a mudança de gestão municipal em 1993, a realização de grandes operações urbanas vinculadas a processos de remoção de favelas. O caso da operação urbana Água Espraiada é um exemplo da associação das remoções ao adensamento da região de mananciais, conforme demonstrou Fix (2001). Ou seja, os poucos avanços de ações de governo acabam resultando em descompassos quando há mudança de gestão, alterando o teor dos programas em curso e causando muitos retrocessos em relação a ações já executadas. As descontinuidades na implementação da política habitacional em São Paulo e a falta de um plano municipal de habitação também contribuiu para alguns desentendimentos analíticos quanto ao caráter das ações realizadas, pois incorporam as disputas de gestão.

Se no momento inicial a urbanização de favelas apresentava-se em resposta à política de remoção, hoje devemos pensar a consolidação tendo em vista a qualidade de tal ambiente construído em relação à cidade. No entanto, em áreas não só ambientalmente frágeis, mas de proteção aos mananciais, a vinculação necessária entre a pauta social e a ambiental estabelece desafios adicionais.

No caso do Complexo Cantinho do Céu, as remoções - desde o início da ação da Promotoria - constituiu-se como perspectiva para o enfrentamento da questão. A alteração nos rumos dos bairros diante da nova lei, com vistas à urbanização, no entanto, não evitou a ocorrência de remoções nos mesmos. As remoções incidiram principalmente na faixa marginal à represa, sendo mobilizados critérios técnicos de saneamento e retirada de casos de risco de morte. Uma vez definido os perímetros de remoção, o trabalho social desempenhado na execução do projeto consistiu em atender essa demanda do próprio projeto. Segundo Rita Madureira, coordenadora social do Programa Mananciais/SEHAB foram trabalhadas três possibilidades ao morador a ser removido: "A família 
pode optar por uma unidade habitacional construída próxima ao local atual, receber o valor da casa antiga a título de indenização ou pode optar pela compra de uma moradia na região"67.

Conforme lista de atendimentos disponibilizada para a pesquisa ${ }^{68}$, do total de 1760 atendimentos realizados até 2012 no Complexo Cantinho do Céu, 521 referem-se ao Parque Residencial dos Lagos, e 1239 ao Cantinho do Céu. Convém esclarecer que o número de atendimentos não corresponde necessariamente ao número de famílias removidas, já que eram atendidos inquilinos e proprietários. Portanto, os dados apresentam um movimento ou tendência, trabalhando com aproximações. Por exemplo, um mesmo proprietário pode possuir vários imóveis de aluguel e não necessariamente morar no bairro ou na área de remoção, distorcendo qualquer apuração que adote o dado de atendimento como família, uma vez que a listagem não discriminava a condição inquilino-proprietário. De acordo com esta lista, os atendimentos foram agrupados em dois tipos: o primeiro denominado Atendimento Definitivo, que correspondia aos atendimentos realizados pela indenização à família pelos custos da construção realizada e pela compra da moradia na região. O segundo correspondia aos atendimentos de auxílio-aluguel, agregando as famílias já transferidas para o Conjunto Habitacional Mata Virgem, entregue em 2012, no distrito de Pedreira. O Quadro 3 a seguir demonstra os atendimentos por bairros:

\begin{tabular}{c|c|c|c|c} 
& Resid. dos Lagos & Cantinho do Céu & Total & $\%$ \\
\hline compra de moradia & 481 & 1180 & 1661 & $94 \%$ \\
\hline auxílio aluguel & 3 & 24 & 27 & $2 \%$ \\
\hline UH Mata Virgem & 37 & 35 & 72 & $4 \%$ \\
\hline Total atendimentos & 521 & 1239 & 1760 & $100 \%$
\end{tabular}

Quadro 3 - Atendimentos no Complexo Cantinho do Céu até 2012. Elaboração: MATSUNAGA (2015) a partir de lista de atendimentos fornecida pela SEHAB em 2013.

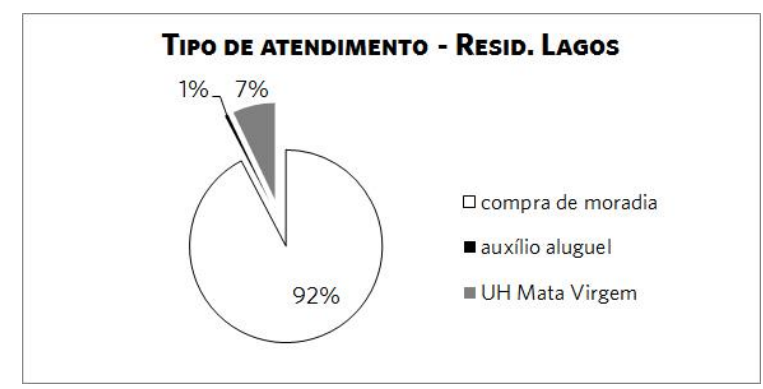

Gráfico 1 - Tipo de atendimento no bairro Parque Residencial dos Lagos até 2012.

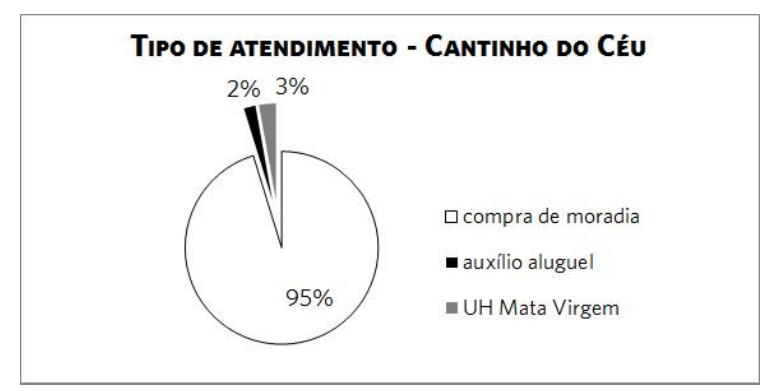

Gráfico 2 - Tipo de atendimento no bairro Cantinho do Céu até 2012.

${ }^{67}$ Em diálogo realizado entre Marisa Barda e Rita Madureira intitulado "O olhar da assistente social" (BARDA e FRANÇA, 2012:130).

68 A lista de atendimentos foi disponibilizada para pesquisa em julho de 2013 pela coordenação social do Programa Mananciais/SEHAB-PMSP. Os dados obtidos correspondiam aos nomes dos titulares, endereços no bairro, endereços de destino, valores pagos e datas da remoção realizadas até 2012. 
Apresenta-se aqui apenas a organização dos dados referente ao bairro Parque Residencial dos Lagos, que corresponde a 521 atendimentos (cerca de 30\%) por configurar a quase finalização da intervenção proposta naquele bairro.

Do total de 521 atendimentos realizados no Parque Residencial dos Lagos, a compra de moradia correspondeu a 92\% dos atendimentos, sendo realizadas 481 indenizações, contabilizando no total $\mathrm{R} \$ 10.643 .949,00$, em média de $\mathrm{R} \$ 22.128,79$ para cada atendimento indenizado, com valores pagos entre $\mathrm{R} \$ 5.000,00$ e $\mathrm{R} \$ 130.000,00$. O auxílio-aluguel correspondeu a $8 \%$, atendendo a 40 atendimentos, sendo que 37 deles já se encontram na nova moradia no Conjunto Habitacional Mata Virgem (ver Quadro 4) ${ }^{69}$. Os dados revelam de forma expressiva que a grande maioria dos atendimentos, portanto, foi realizada mediante a indenização ou compra da moradia, em detrimento do atendimento em nova unidade habitacional. Diante desse número expressivo de atendimentos através de indenização ou compra de moradia, buscou-se qualificar os deslocamentos através do endereço indicado de destino na lista, cuja informação também permitiu realizar um mapeamento, indicando os deslocamentos provocados na região.

\begin{tabular}{clr|r}
\multicolumn{4}{c}{ Parque Residencial dos Lagos } \\
\hline \multirow{2}{*}{ Qualificação dos deslocamentos } & no. atend. & \multicolumn{1}{c}{$\%$} \\
\hline \multirow{3}{*}{ compra de moradia } & Continuam no bairro & 77 & $14,8 \%$ \\
\cline { 2 - 4 } & Outro bairro/outro Município da RMSP & 303 & $58,2 \%$ \\
\cline { 2 - 4 } & Outro Município fora da RMSP ou Estado & 10 & $1,9 \%$ \\
\hline \multirow{2}{*}{ aluguel/UH } & Bolsa-aluguel & 3 & $0,6 \%$ \\
\cline { 2 - 4 } & UH Mata Virgem & 37 & $7,1 \%$ \\
\hline não foi possível mapear & & 91 & $17,5 \%$ \\
\hline TOTAL & & 521 & $100,0 \%$
\end{tabular}

Quadro 4 - Qualificação dos destinos informados em lista de atendimentos no bairro Residencial dos Lagos até 2012. Elaboração: MATSUNAGA (2015) a partir de lista de atendimentos fornecida pela SEHAB em 2013.

Com base nas informações da lista, foram mapeados os destinos informados na negociação feita caso a caso. O mapeamento sugere que o destino da população removida se concentrou na região e alguns até mesmo no próprio bairro, como era de se esperar já que a compra da moradia consistia no procedimento de "troca" negociada de acordo com o valor estipulado para o imóvel privilegiando a própria região como destino (Ver Figura 39).

\footnotetext{
69 Inicialmente, parece certo indicar que no Lago Azul, 92\% tiveram a construção indenizada e $8 \%$ foi para o bolsa aluguel, tendo apenas $1 \%$ hoje nesta condição. Porém, ao analisar os nomes das pessoas contempladas verificou-se duplicidade de alguns registros. Esse dado a priori pode apontar um desvirtuamento dessa indicação inicial; o fato do mesmo proprietário ter sido indenizado diversas vezes, coloca a suposição de que ele seria proprietário de vários imóveis removidos. No entanto, como estes números implicaram em apenas 15 duplicidades, os dados foram mantidos.
} 


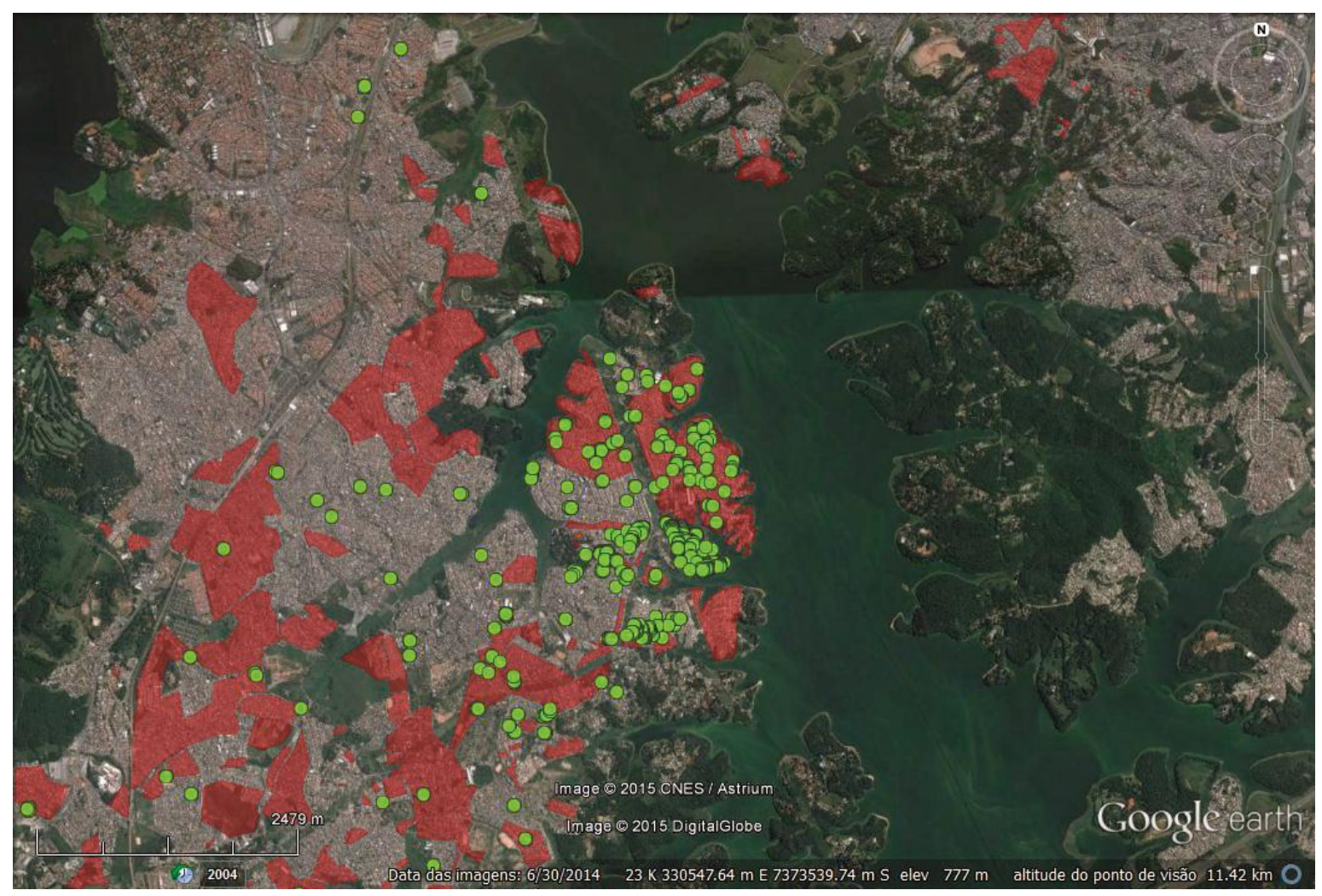

Figura 39 - Destinos localizados em relação às remoções realizadas até 2012 no bairro Parque Residencial dos Lagos ${ }^{70}$ com $^{-1}$ sobreposição aos assentamentos precários (loteamentos irregulares, favelas e núcleos urbanizados). Fontes: lista de atendimentos fornecida pela SEHAB/PMSP em julho de 2013 e HABISP/PMSP. Elaboração: MATSUNAGA (2015).

No caso específico do Parque Residencial dos Lagos, a indenização, cujo valor foi auferido por tabela de preços e negociação com o proprietário, representa um avanço em relação à prática desrespeitosa do "cheque-despejo", cujos valores são padronizados e bem abaixo do valor da moradia ${ }^{71}$. Além disso, a compra assistida sugere um "controle", ao agenciar o procedimento de compra e venda da residência que busca garantir que a família indenizada não tenha como destino outro assentamento inadequado. De modo geral, a configuração do tratamento da remoção nos termos indenizatórios, sem incentivo ao atendimento a nova unidade habitacional construída para tanto, é alvo de crítica generalizada por parte dos estudos acadêmicos, que visam aprimorar a

\footnotetext{
70 Foi utilizado para o mapeamento o Google Maps Engine Lite, ferramenta online que permite a localização do endereço e sua inserção geográfica. A adoção de tal ferramenta incide em aproximações das localizações, já que muitas ruas não correspondem à base online. Quando o endereço era indicado em locais não disponíveis nessa base, foi utilizada a base CESAD-FAUUSP para localização dos mesmos.

${ }^{71}$ Cumpre destacar que a metodologia de atendimento às famílias removidas no Complexo Cantinho do Céu não configura uma prática que se estende ao Programa Mananciais. Como exemplo da diferenciação, há o caso do bairro Parque Cocaia1/Toca, no âmbito do Programa Mananciais em 2007, onde houve o pagamento de 8 mil reais conseguidos após intermediação da Defensoria Pública a favor das famílias removidas, já que o valor inicial era de 5 mil reais, conforme aponta Polli (2010) em sua tese de doutorado. Conversei com uma das ex-moradoras removidas em tal ocasião e que hoje reside no Conjunto Residencial Mata Virgem. Segundo a ex-moradora a indenização de 8 mil reais deveria ser aplicado em despesas com aluguel, configurando o pagamento inicial do bolsa-aluguel, permanecendo por três anos com o auxilio. Além do prejuízo que teve, já que morava "num sobrado grande de 100 mil reais" e do modo violento, desrespeitando os moradores e obrigando os mesmos a se retirarem no mesmo dia do pagamento, seus irmãos que também moravam com ela não foram atendidos.
} 
política habitacional e urbana ativada pelo Estatuto da Cidade (Lei 10.257/2001), já que incide no deslocamento compulsório da população sem atender de modo efetivo a demanda habitacional que a intervenção origina. Nesse sentido, convém destacar a análise de Silva (2011:124) acerca da "ingovernabilidade" na área de mananciais, "em que não é possível remover, tampouco regularizar todos os moradores instalados". Segundo esta autora, "as práticas de gestão operam por cisões do espaço, estabelecidas entre as áreas regularizáveis e aquelas que não o são". Esse aspecto, sem dúvida, merece aprofundamento analítico e estudos que conjuguem outros dados do Programa Mananciais ou mesmo da política habitacional podem ser realizados a posteriori.

Do ponto de vista de alguns moradores que permaneceram no Residencial dos Lagos, as famílias que foram removidas ficaram satisfeitas com os valores pagos, dado que "foram indenizadas e conseguiram comprar a casinha deles e tão bem também" sendo esse período de remoção no bairro, relativamente tranquilo, "sem rebuliço". Talvez porque os removidos constituíam o grupo dos "outros" que estavam sendo forçosamente deslocados, mas que nenhum deles curiosamente mantinha contato muito próximo.

Já no Cantinho do Céu, a incerteza referente aos polígonos de remoção ainda é presente. Seo Pedro, cuja narrativa abordo no item 3.3 deste Capítulo, morador de uma área delimitada para remoção, faz um apelo diante da desinformação do poder público sobre as obras em curso:

O pessoal com um jaleco da prefeitura falou que é área de remoção. Mas isso já faz aproximadamente dois anos e meio. Então você fica na dúvida: vai sair ou não vai? Eu queria uma certeza do Poder Público. Isso que é minha dúvida que paira, é a dúvida de muitos moradores. Inclusive se você tivesse acesso ao Poder Público para me esclarecer isso eu ficaria muito agradecido. Porque você não pode ficar sendo morador com aquele ponto de interrogação eternamente. E você vai lá, é evasivas. Não tem. Ah... tá parado, não sabe quando? Não é assim, não é dessa forma! Isso não é uma resposta concreta! Vai ficar ou vai tirar?

Permeando este tema de remoções e deslocamentos, inicialmente apresento a narrativa de Lucia, moradora do Cantinho do Céu, que fora removida pelo projeto em 2009 e continuava morando no bairro na época da entrevista. Em seguida, apresento a história de Débora, moradora do Cantinho do Céu, cuja remoção não fora realizada pelo projeto de urbanização, contudo, teve a casa interditada pela Defesa Civil por risco de deslizamento. Sigo na narrativa de Seo Pedro e Cleonice, moradores do Cantinho do Céu, com a incerteza sobre a remoção anunciada há mais de dois anos. Posteriormente apresento a entrevista de Eunice e Carlos que são removidos do Lago Azul e hoje moram no Cantinho do Céu. Por fim, apresento a narrativa de Lucilene, removida do Lago Azul e que mora atualmente no Conjunto Habitacional Mata Virgem. 


\section{1 À paulistana}

\section{LUCIA}

Eu vim pra cá em 99. Na época que eu vim pra cá foi anunciado que as casas iam sair da beira da represa, aí a pessoa que morava na casa que eu comprei entrou em desespero, se apavorou e vendeu baratinho pra mim. Eu fiquei sabendo através do meu irmão que é carteiro. Minha cunhada, Alzira, estava começando a entrar para a associação do bairro e ela já estava conhecendo as ruas, conhecendo as famílias. Ela era católica e ela fazia aquela visita dos Vicentinos, então nessa visita dos Vicentinos ela visitou essa família que estava passando uma situação muito precária, muito precária mesmo. E a pessoa que vendeu a casa, entrou em desespero, se apavorou, chorou muito. Aí ela resolveu vender e voltar para a terra dela, que ela é gaúcha. Meu irmão falou: - Ó Lucia, se você quiser comprar tá avisado que vai sair, que vai tirar, mas tenta, de repente não é pra agora, pode demorar mais um pouco ou eles podem indenizar, talvez aconteça... e como estava muito barato, compensa você comprar, tenta a sorte. Talvez saia ou não, mas tá saindo de graça. E o terreno era bom, de esquina, muito grande.

Lucia tem 43 anos e dois filhos, Amanda, de 24 anos e Felipe de 19 anos. Lucia nasceu em São Paulo numa família de treze irmãos. A mãe é do Ceará e o pai de Pernambuco. Saiu da Cidade Dutra para morar no Cantinho do Céu com 28 anos, quando Amanda já tinha 9 anos, auxiliada pela família do irmão mais velho que já morava no Cantinho do Céu. Na época da entrevista, julho de 2013, Denis, sobrinho de Lucia, tinha vindo da Paraíba e estava ficando temporariamente na casa.

Conheci Lucia na ocasião da conversa coletiva na casa de Dona Rosa, em março de 2013, e diante de sua apresentação, quando contou que tinha sido uma das famílias removidas, marcamos uma entrevista alguns meses depois, em julho de 2013. Apesar de quando ter se mudado para o bairro, em 1999, ela já ter ciência da possibilidade de remoção - que provavelmente era em atendimento à medida liminar do expedida pelo juiz em 1998 - o preço baixo lhe pareceu uma ótima oportunidade de correr o risco. Anos mais tarde, em 2009, quando o projeto já estava começando na região, mudou-se para outra casa no bairro, também em área de remoção. Foi uma das removidas pelo projeto de intervenção, esperava receber 80 mil na casa, mas acabou sendo indenizada no valor de 55 mil. A trajetória de sua vida na cidade de São Paulo foi o grande enfoque da conversa, demonstrando um histórico de conflitos familiares, com uma infância distante da família e estratégias de vida no enfrentamento das dificuldades quando adulta. Mantivemos contato posteriormente por redes sociais.

Apesar da família numerosa, o pai de Lucia não foi presença marcante em sua vida. A relação de seus pais sempre fora acompanhada pelos avós paternos, que segundo ela, era quem cuidava com carinho das crianças. O pai de Lucia, de quem ela não se lembra muito bem e relata 
conforme o que os amigos e vizinhos contam, tinha problemas sérios de saúde mental e a mãe nunca achou que houvesse algum problema com ele:

Os vizinhos dizem: - Teu pai, Lucia, tinha realmente problema mental. Mas sua mãe não sabia, não sabia lidar com a situação. Tua mãe aceitava simplesmente ele como marido dela, como uma pessoa normal. "Um marido bom, pai dos meus filhos, ele é um bom pai - é o que ela falava né. Mas judiava da gente, batia na gente. Pegava minhas irmãs e jogava pro alto pra cair no chão. Insano. Mas minha mãe não via isso nele. Ela achava ele uma pessoa boa: meu marido não rouba, não mata, não faz mal pra ninguém... Mas ele judiou muito da minha mãe.

Durante a última gravidez da mãe, o pai de Lucia a agrediu violentamente: "meu pai quase matou minha mãe com um ferro". O pai foi condenado pela tentativa de homicídio e alguns meses após sua reclusão, cometeu suicídio. Além dos transtornos psíquicos não só da violência doméstica, mas, também, da perda do marido, e diante da impossibilidade de sustento dos filhos, que já somavam treze, a mãe perdeu a guarda das crianças e Lucia ficou num internato somente com uma das irmãs, entre os 5 e os 9 anos de idade.

Nós todos fomos parar num colégio interno. Nós todos, tudo separado, cada um prum lado. Eu fiquei com uma irmã mais velha num, minhas irmãs pequenininhas foram pra outro lugar, meus irmãos também. Depois que minha mãe ficou ruim da cabeça, por causa desse machucado. Ela teve a minha irmã, mas ela ficou ruim da cabeça. O juiz foi lá ver a situação, pois fomos parar na delegacia, e a delegacia acionou o juiz. Olha, tem que lá ver a situação, pois as crianças estão todas abandonas lá, sem parente, sem ninguém. Aí o juiz determinou de internar nós tudo. Porque agora a mãe tá doida também, tá internada. Aí foi internando a gente onde tinha vaga, ficamos tudo separado.

Segundo Lucia, a morte do pai na cadeia resultou em assistência institucional à mãe, que após tratamento, teve ajuda para adquirir uma nova moradia e retirar as crianças do abrigo.

Minha mãe ficou melhor, tomou remédio e ficou boa da cabeça. E a prefeitura deu um terreno, eles ajudaram a minha mãe a ter um terreno, na Dutra lá. Deram uma parte do terreno para ela. Ela construiu dois cômodos e o juiz deu ordem de ela pegar a gente de volta: - Agora a senhora pode pegar porque a senhora tem onde ficar com eles, não tá pagando aluguel e vai receber o dinheiro do meu pai que morreu.

Lucia lembra que quando foi a ocasião da saída do abrigo, que não era sua vontade, pois não se lembrava mais da mãe: "E eu não queria sair porque eu não me lembrava da minha mãe. Eu chorava, chorava". Quando completou 18 anos, Lucia descobriu que nessa época da morte do pai, a mãe recebera uma indenização, e que pensando no futuro dos filhos, decidiu guardar o dinheiro no colchão permanecendo esquecido até perder o seu valor monetário:

Pra você ter uma ideia de como minha mãe, tadinha, não tinha noção: ela recebeu uma indenização do governo, eu acho, altíssima, um dinheirão. Não sei 
porquê ela não falou. Não sei se quem recebeu com ela, não a orientou a guardar no banco esse dinheiro, o que fazer com o dinheiro. Só sei que quando a gente soube desse dinheiro a gente já estava tudo de maior, eu já estava com 18 anos, foi antes da Amanda nascer, e quando eu vi o bolão de dinheiro debaixo do colchão da minha mãe, menina... Era muito dinheiro, aquelas notonas de 500, 500 cruzeiro. Era tanta nota de 500 cruzeiro. Era tanto dinheiro. Será que vale? perguntei para Dona Dulce, na época era minha patroa. Ela falou assim: - Não vale mais filha, pois do tempo que seu pai morreu e tua mãe tinha que ter gastado o dinheiro. O dinheiro tá lá dentro do colchão. Mas era tanto dinheiro.

Quando sai da casa da mãe para morar no Parque Fernanda, Lucia já tinha a Amanda, que estava com quase dois anos de idade para trabalhar de babá do filho de um tio. Nesse período, ela engravidou, e devido à descoberta da traição do pai da criança, negociou uma indenização frente ao juiz, abrindo mão de pensão e afastando Felipe do pai:

Então, aconteceu que eu não morei com nenhum dos dois, dos pais dos meninos. Não cheguei viver, não cheguei a ter uma convivência, de morar junto não. Com o pai do Felipe eu até que morei com ele um tempo, que foi nessa época que eu saí da casa da minha mãe... e a Amanda já estava com um ano, quase 2 aninhos, quando eu saí da casa da minha mãe para morar com meu tio. Que o pai do meu filho morava na casa do meu tio. Mas não era primo meu, era enteado do meu tio. Daí na época que eu fui morar com meu tio, porque meus irmãos bebiam muito, enchia o saco. E eu sempre trabalhei. Meu tio falou: você tá parada, você não quer trabalhar na casa da minha namorada? Que a namorada dele era enfermeira, do Hospital Santa Cruz, ela tá grávida de mim, vai ter a menininha, e se você quiser cuidar do nosso bebê e eu te pago. Você fica cuidando da minha neném. Só que você tem que morar na minha casa, que a gente sai de madrugada e chega tarde. Aí foi essa época que eu fui morar lá. Saí da casa da minha mãe e fui morar com meu tio no Parque Fernanda. Eu fiquei com a Amanda, dois anos morando lá. Aí quando eu voltei, voltei grávida do Felipe. Aí eu estava morando com o pai do Felipe. Meu tio tinha duas casas, eu ficava na de baixo. A gente estava até bem, quando eu descobri uma traição, eu estava grávida e a outra mulher dele também estava grávida. A outra menina, que ele tirou a virgindade, engravidou. Aí ele casou com a menina lá, que a menina era virgem. Quis casar com ela, preferiu ela. Essa história eu dei um fim assim: acabou na audiência do juiz, eu recebendo uma indenização e acabou a história.

Lucia estava morando novamente com a mãe e os dois filhos quando soube da oportunidade no Cantinho do Céu:

A casa em si não era boa não. Mas o terreno era um terreno de esquina muito bom. Tinha bananeira, pé de mandioca. Aí eu falei com minha patroa, na época eu estava trabalhando em casa de família né, dona Zoé. Ela era advogada, e eu falei, olha dona Zoé, apareceu uma oportunidade de comprar minha casa, tá barato o preço tal, apesar que o local é meio arriscado e tal, mas pelo preço, como eu não tinha casa própria, tinha dois filhos já, morava com minha mãe e meus irmãos. Meus irmãos bebiam né. Daí eu tinha que trabalhar, deixar meus filhos, sempre que meus irmãos bebiam eu não confiava de jeito nenhum em deixar na casa da minha mãe, então eu sempre tinha que pagar pra deixar com alguém fora da casa da minha mãe. Aí minha patroa falou, já que você passa por essa situação 
lá na tua mãe, a gente senta, se você quiser mesmo comprar, você achar que vale a pena porque a área é arriscada, você pode perder seu dinheiro. Mas aí ela sentou comigo, me pagou o tempo, que eu já tinha 5 anos com ela de trabalho. Eu faço o seguinte: vou te pagar o seu tempo de casa, pago suas férias, seu décimo, seu acordo aqui e você compra.

Nessa época em que se mudou para o Cantinho do Céu, Lucia, além de trabalhar como empregada doméstica, também vendia bolos e doces no bairro e nas portas dos hospitais, de maneira a complementar sua renda. E foi numa dessas trocas que conheceu Pedrão, que viria a ser seu companheiro e assumir praticamente a função de pai de suas crianças. No entanto, ele faleceu por sequelas de paralisia infantil, segundo Lucia:

O Pedrão, ele era muito comunicativo, muito conversador. Ele assumiu os dois, não no papel, mas na responsabilidade de pai, de educar, de ensinar, de me ajudar a criar eles. Ele faleceu com 36 anos. Ele nasceu em Pernambuco e ele não tomou aquelas injeção, sabe de paralisia infantil? Então deu de adulto, essa paralisia deu nele adulto. Ele veio a ter sintomas dessa paralisia de 29 anos a 33 anos. Quando a gente descobriu a doença, ele já estava com 33 anos. Foi aquela luta pra reverter né. Mas não tinha reversão.

Após a morte de seu companheiro Pedro em 2007, ela ficou "meio atrapalhada da cabeça" e resolveu alugar a casa onde morava - que existe ainda hoje, à esquina da Rua Nossa Sra. de Fátima, lado de cima - para dividir a moradia com o novo namorado Sergio em 2009. Esta segunda casa ficava numa viela da Rua Nossa Sra. de Fátima, lado de baixo, próximo à represa, exatamente no perímetro configurado pelo projeto para remoção que ocorreu em 2011. Lucia narrou o procedimento da remoção pelo qual passou:

Se você quiser continuar aqui no bairro é por sua conta, se quiser sair também é por sua conta. Eles só pegam o comprovante de onde é a rua que você comprou, que você quer comprar. Porque eles só te dão o dinheiro se eles aprovarem o local. Se eles não aprovarem o local eles não te dão o dinheiro. Aí como eles aprovaram aqui a Cairu, a rua, a casa tudo. E essa casa que eu to não é compatível com a que eu tinha, não é. Eu bati o pé, bati o pé pra eles aumentarem o valor. Porque a minha casa, a outra, ela valia no valor de 80 mil. Mas aí eu bati o pé, briguei lá mas não teve jeito. Ficou demorando muito, uma enrolação. Aí como o pessoal foi saindo, foi saindo, foi saindo e só estava ficando eu lá, eu fiquei com medo e aceitei essa proposta.

A indenização de Lucia foi negociada no valor de 55 mil reais. A casa na Rua Cairu não tinha sido a primeira opção de Lucia. Ela queria se mudar para um condomínio no Jd. Noronha. Mas, ao chegar lá e verificar as reais condições do bairro e do condomínio, logo se arrependeu. A ida para o Noronha e volta para o Cantinho do Céu se deu no mesmo dia, marcado por grande prejuízo, já que a maioria de seus móveis ficou como pagamento da quebra de contrato com a 
imobiliária, além do desalento de voltar ao bairro e não ter onde ficar, já que sua casa já tinha sido demolida:

Eu cheguei a sair do bairro, fui pra outro lugar, fui pro Noronha. De caminhão de mudança tudo. Só que eu estava fazendo um negócio sem a prefeitura saber. Eu estava comprando uma casa num condomínio lá. Eu me iludi com o condomínio, me iludi com a casa, com o preço da casa. E aí eu resolvi fechar sem a prefeitura saber. Só que a minha sorte foi que antes de ir lá no banco e passar o dinheiro para o proprietário, no dia da mudança oficial mesmo, que foi pra de vez ficar, tocou no meu coração de eu não ficar ali. Na hora não sei, comecei a chorar, não queria mais ficar ali. Estranhei tudo, não gostei mais de nada. Aí comecei a andar com o rapaz da imobiliária, nas ruas assim e era um lugar muito deserto. Aí eu parei pra pensar bem, porque eu estava na verdade fazendo uma grande besteira. Eu me iludi foi com o condomínio lá. Era um condomínio particular, não sei o quê, não sei o quê. Só que quando o rapaz me mostra onde tem as coisas, mercado, padaria... do bairro em si. Porque foi uma coisa rápida também, esse negócio. Você sabe quando você compra as coisas muito rápido, você acaba não observando de fato os defeitos, só vê a casa, o local, mas as outras coisas você não vê na hora. Aí no domingo o rapaz: entra aí que a gente vai dar uma volta pra você saber onde que é a padaria, onde que é mercado, qual é o caminho pra você chegar nesses locais. Só tinha escadão! Era escadão pra ir pra farmácia, era escadão pra ir pra padaria, era escadão pra chegar não sei aonde, na escola. Eu estava num buraco! E minha mudança já estava tudo lá. Mas e esse matagal? - Aqui é uma área verde, tem que preservar a área, não pode tirar essa área verde - tinha muito mato envolta do condomínio. E assim, numa parte de cá era um matagal e nessa parte aqui de trás era uma favela. Você não via casas assim, era uma favela. Fora isso aqui, o que que tem mais? Não, aqui é a área verde, aqui é a favela. Daí, pronto, me desgostei na hora. Não to louca não, sair do Cantinho do Céu, que tá tudo no asfalto, tudo arrumado, tudo urbanizado e vou me enfiar aqui não. Sinto muito, eu vou pro meu Cantinho do Céu. Era uma favela assim, as casas não eram de barraco, algumas eram, algumas não. Era uma rua assim, uma casinha encostada na outra, viela, umas 3 vielas, sabe, bem favelinha mesmo. Quando eu vi aquilo eu me assustei, porque meus filhos, vai trabalhar, chegar da escola, vai ter que passar por esse caminho, descer escadão, subir escadão, eu vou ficar isolada aqui nesse buraco, não conheço ninguém. Aí eu desisti. Aí eu peguei, deu uma crise de choro lá - quer saber moço, to me desfazendo do negócio agora aqui. To pegando meu caminhão aqui, aproveitar que tá aqui ainda, vou levar minhas coisas, to voltando pro meu bairro. Ele falou: - Não, mas nós já fizemos contrato. -Eu não quero nem saber de contrato não, vou voltar pro meu Cantinho do Céu. - A senhora não tem pra onde ir. - Ah, eu arrumo, lá eu arrumo, eu conheço todo mundo lá, eu volto, eu me viro lá com o caminhão, com a mudança, com tudo. E dito e feito, quando eu cheguei com o caminhão aqui de volta, um dia antes de eu mudar, um dia antes da mudança a minha casa já tinha sido demolida. Que é assim, assim que cai o dinheiro na conta, na mesma hora os caras vêm derrubar sua casa, pode ser de noite, pode ser de madrugada, os caras tão derrubando sua casa. $E$ foi o que aconteceu. O cheque caiu na sexta-feira às $11 \mathrm{~h}$ da manhã, quando foi cinco horas, os caras chegaram cinco horas da tarde, da prefeitura, todo o pessoal deles lá. E já tavam martelando minha casa, já tinham quebrado laje, já tinham quebrado tudo. Nem tinha como eu entrar pra dentro lá mais. Aí eu peguei o caminhão de volta, isso no domingo de manhã mesmo, cheguei aqui por volta de uma hora e meia da tarde, aí eu conversei com o dono da casa, olha, deixa eu voltar pra lá depois a gente resolve 
esse contrato, e daí como era pela imobiliária também eu tive que pagar uma multa. Como eu não tinha dinheiro pra pagar essa multa, a maioria dos meus móveis que eu tinha levado ficou pra lá. Eu perdi celular, dos meus filhos, ficou tudo pra eles lá, os móveis ficou pra imobiliária porque ela falou que eu tinha que pagar por uma tal de uma indenização. Eu falei: - Eu não tenho dinheiro pra pagar essa indenização. - Mas tem que pagar porque é quebra de contrato. - Aí o que eu posso fazer é deixar aí, vou levar só o que der pra mim levar aqui no caminhão, pronto e acabou, pode ficar pra vocês o que tiver dentro aí da casa. Já tinha muita coisa dentro da casa, eu deixei, eu só pude pegar o que estava no caminhão, umas coisas que tavam na garagem. A imobiliária falou você só pode levar daí pra fora, o importante é acertar o preço da multa, você não pode pegar nada aqui. Aí eu falei, então tá, pode ficar pra você então que eu só quero ir embora desse lugar aqui. É só o que eu quero. E pronto.

Ao voltar ao bairro, Lucia ficou numa casa vazia onde permaneceu temporariamente até encontrar esta onde mora atualmente, na Rua Cairu. Segundo Lucia, a moradora anterior fora removida do Lago Azul, sendo indicada a moradia pela própria prefeitura:

Aí morava ela e uma filha com seis crianças dentro. E é dois cômodos só. E ela estava morando há 2 anos ali, porque ela estava na mesma situação que eu. Ela conseguiu a casa através da prefeitura. Ela não pegou indenização. A Prefeitura comprou essa casa, que é uma casa grande, de terreno enorme, dividiu no meio, metade para Cleonice e a outra metade para Eunice* que é minha vizinha hoje, as duas moravam num sobradinho. Era duas famílias, uma embaixo e a outra em cima. Como a prefeitura tirou as duas lá do Lago Azul, a prefeitura comprou esse terreno, essa casa que estava à venda lá, o proprietário vendeu, a prefeitura dividiu assim pra duas famílias. Daí ficou a Eunice desse lado e a Cleonice desse, que foi onde eu comprei.

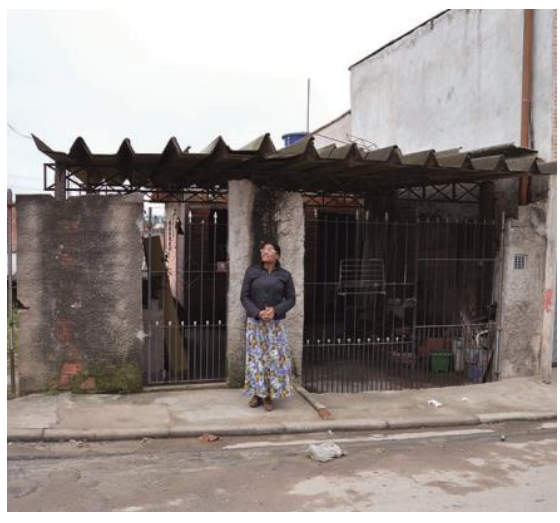

Figura 40 - Lucia e sua casa à Rua Cairu. Crédito: Melissa Matsunaga, 2013.

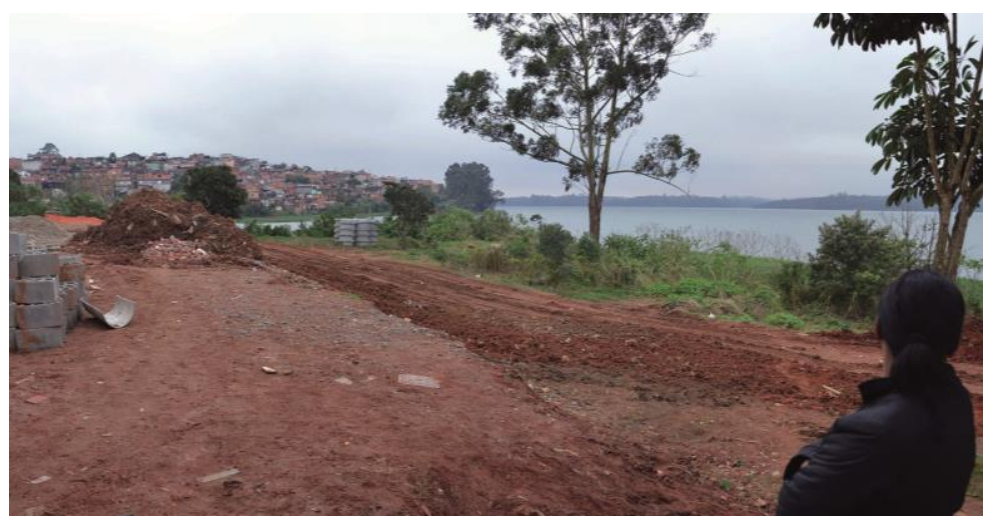

Figura 41 - Lucia e o local da sua segunda moradia (entre 2009 e 2011) no bairro Cantinho do Céu, de onde foi removida. Crédito: Melissa Matsunaga, 2013.

Quando a entrevistei em sua casa, Lucia estava com uma obra parada na parte da frente do lote e a ideia era trazer a mãe, da Cidade Dutra, para morar com ela. Naquela época, Lucia estava desempregada e, por isso, estava construindo aos poucos. Ela havia terminado a Escola de Jovens Adultos (EJA) recentemente e pensava em fazer algum curso para abrir seu próprio negócio, 
facilitado pela condição de que "no bairro não se paga imposto". No entanto, a visita que faria à casa da irmã caçula no Paraná mudaria seus planos:

Como eu estou parada agora, mas eu tenho minha pensãozinha, sou pensionista, recebo pensão. Vou aproveitar que estou parada, vou pegar minha mãe e vou pro Paraná. Tenho uma irmã mais nova que está lá. Ela foi atrás da sogra dela. E a gente vai visitar, faz mais de um ano que ela foi, quase dois. Vou ficar pelo menos uns 10 dias lá.

Desde quando Lucia viajou ao Paraná, foram raros os momentos que retornou a São Paulo. Como mantivemos contato por redes sociais, ela informou que se mudou para Sarandi-PR, cidade de sua irmã caçula. Seus filhos, Amanda e Felipe continuam morando no Cantinho do Céu. O irmão mais velho de Lucia, aquele que indicou a oportunidade da casa no bairro em 1999, continua morando no Cantinho, na Rua Copacabana. Apoiada por uma rede familiar de tios e irmãos, ela traça sua trajetória na cidade sempre em busca de melhores oportunidades. Quando se muda para o Cantinho em 1999, ciente do risco de sua remoção, a oportunidade expressa pelo valor baixo não lhe deixou dúvidas quanto à decisão da compra. O triste episódio marcado na sua remoção em 2011 quando seu anseio em morar num condomínio é frustrado ao deparar com as condições reais do bairro, associado a um destino incerto num bairro desconhecido, também evidencia um afeto ao bairro em processo de intervenção, ainda que fora excluída dele. A atitude em retornar, portanto, se faz permeada por sentimentos de pertencimento e, ao mesmo tempo, desilusão. Ainda que a intervenção urbana interfira diretamente no destino de cada uma das famílias, sua trajetória não pode ser encarada passivamente e, sim, diante das possibilidades que a vida e suas relações humanas exercem, vinculando expectativas e desejos dos vivenciadores em sua condução.

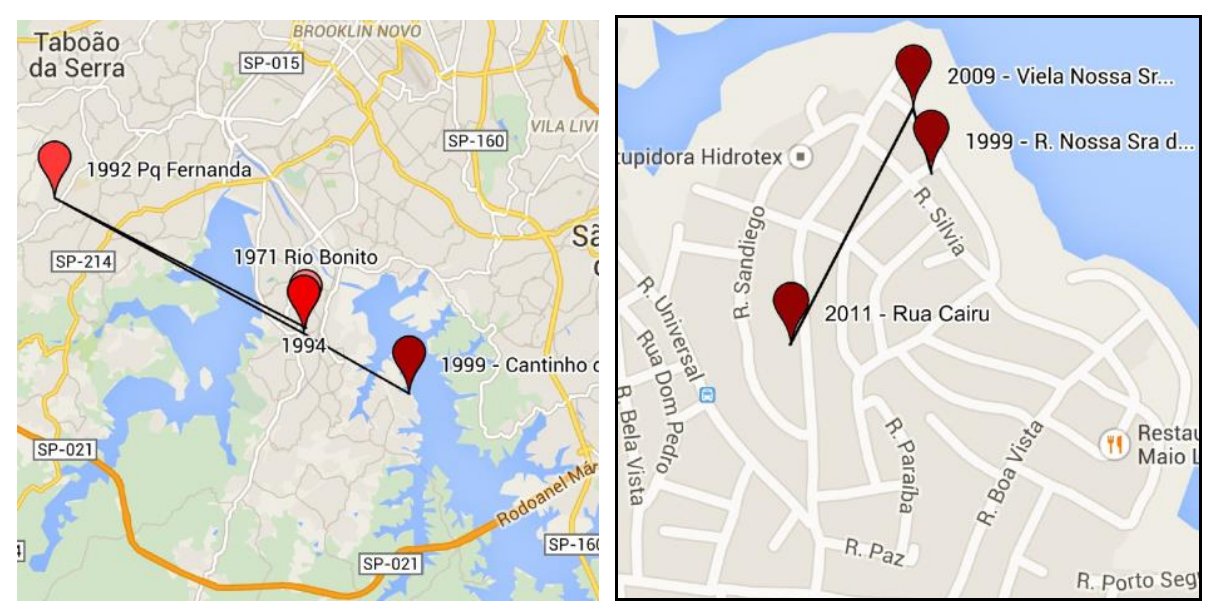




\subsection{EM BUSCA DO PORTO SEGURO}

\section{DÉBORA}

Eu não vejo a hora de sair daqui Melissa, não vejo a hora. Olha como que tá as paredes, começa a chover, infiltra tudo pelas paredes...

Débora tem 36 anos, estudou até a 5a série e é mãe de quatro meninas, Carol de 19 anos, Ana Beatriz de 15 anos, Sthefany de 9 e Anny Sthelly de 4. Moram com ela as três filhas mais novas; teve uma relação complicada com a mais velha, expulsando-a de casa em 2011. Numa das brigas com a primogênita, Débora perdeu a guarda de Carol e Bia. As meninas passaram mais de um ano num abrigo. E no momento que a conheci, Débora se recuperava de uma recente depressão.

Conheci Débora num contexto não direto com a intervenção realizada pela prefeitura. Sua casa foi interditada pela Defesa Civil em junho de 2012 e até o momento da nossa primeira conversa, outubro de 2013, seu problema ainda não havia sido solucionado - que seria a liberação da bolsa-aluguel para ela sair da condição de risco e residir num outro local seguro. Como nosso contato se deu por intermédio de Roseli, que acreditou que eu pudesse ajudar a resolvê-lo de alguma forma, esse problema emergencial marcou o início de nossa conversa, que mais tarde se tornaria um acompanhamento de caso. Já de início, contou-me sobre as idas e vindas do caso dela entre a subprefeitura e a SEHAB, sem resolução até aquele momento.

E o que eles falam é que o meu [processo] estava enrolando por falta de informação. Agora eles alegam o quê? Que a SEHAB não tá tendo condições de retirar as pessoas por falta de pagamento do aluguel. O que nós estamos sabendo aqui no bairro, que aconteceu com uma menina aqui no bairro, é o quê? A prefeitura agora tá indo atrás de cada pessoa que recebe auxílio aluguel para verificar se realmente aquela pessoa está morando de aluguel ou está usufruindo do dinheiro da prefeitura. Que é o que aconteceu aqui com bastante gente, tanto que tem gente que não tá nos barracos, tá na casa de parente. Até a prefeitura vir, analisar e depois volta.

Débora, outrora havia comentado que algumas pessoas que estavam morando em barracos no Cantinho do Céu já haviam sido indenizadas pela remoção de suas casas. O caso delas era diferente do seu; estavam no contexto da remoção promovida pela intervenção. De qualquer modo, o seu procedimento para adentrar ao programa de auxílio moradia integrava-se a outras demandas, o que fazia que seu caso fosse considerado mais um dentre tantos. Além disso, segundo Débora, o fato de muitas famílias estarem "usufruindo" a verba do auxílio-aluguel - se refere ao fato dessas famílias não estarem utilizando-a necessariamente para o pagamento da locação, já que estavam morando em casas de parentes ou mesmo em outros barracos, o que distorcia o objetivo do programa - influenciava sobremaneira no seu atendimento. 
- Mas isso tá acontecendo aqui? Você sabe de alguém que a prefeitura foi atrás? D: Não, a prefeitura tá indo, tá começando a ir. A pessoa soube que a prefeitura ia, entendeu? Ela ligou lá porque atrasou o pagamento da prefeitura, tem muita gente com pagamento atrasado, aí disse que a prefeitura quer o endereço de onde a pessoa tá. Porque de início, quando saíram as primeiras casas, eles fizeram o quê? Eles só te liberavam o dinheiro do aluguel depois que você levasse um comprovante de que você tinha ido praquela casa de aluguel. Então vinha um fiscal, analisava a casa que você estava indo morar de aluguel, pra prefeitura liberar o dinheiro. Depois disso eles deixaram de mão. A cada seis meses que eu tenho que te dar o dinheiro? Então a cada seis meses você vai no canteiro, pega o cheque, vai lá na avenida Guarapiranga, troca o cheque, pega aqueles seis meses de aluguel e acerta o seu aluguel. Entendeu? Aí disse que agora eles iam começar a pegar pesado. Ai meu Deus, agora eu to até com medo, porque disse que em Paraisópolis ninguém estava recebendo auxílio aluguel, que era por causa disso as manifestações. Mas daí se eu saio, como que eu vou dar de conta pro proprietário que a prefeitura atrasou um mês? O proprietário não quer saber isso, se a prefeitura atrasou ou o que foi, quer saber de receber o dele, não quer saber se você tá ali pela prefeitura.

Segundo a moradora, o atraso dos pagamentos fazia com que a operacionalização do programa pela prefeitura fosse publicizado ao conhecimento de todos. A justificativa do atraso recaía sobre os contemplados, que estavam por sua vez, utilizando a verba, que é liberada por remessa e não mês a mês, para outros destinos e não ao pagamento do aluguel. $\mathrm{O}$ impasse generalizado incidia diretamente nos pagamentos de quem não tinha inicialmente nada a ver com a ocorrência, adiando no caso de Débora, a resolução do seu urgente problema.

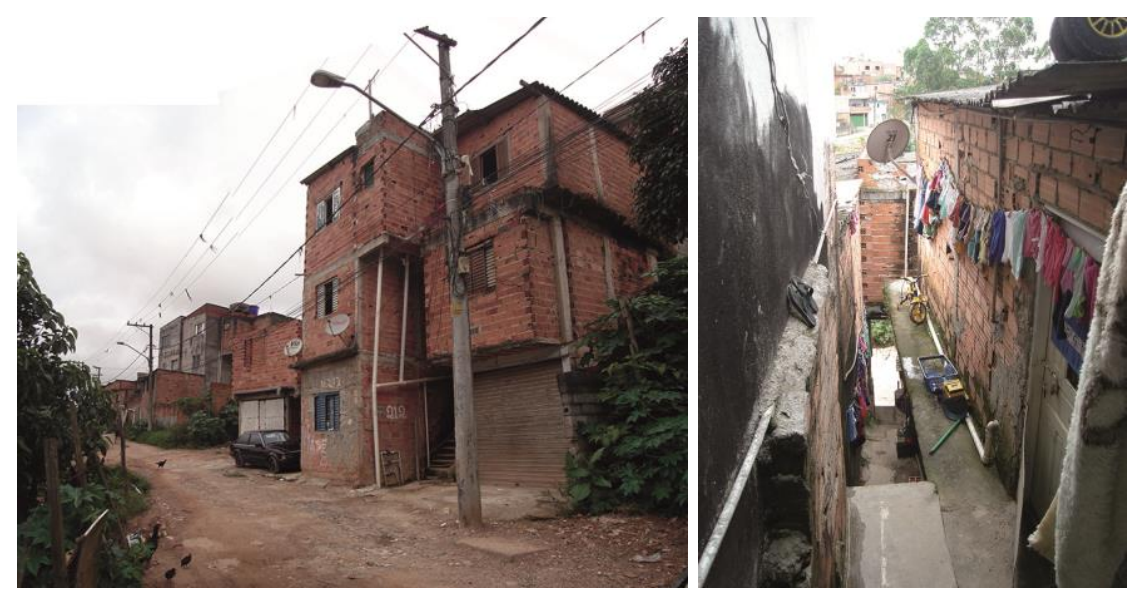

Figura 43 - Rua Porto Seguro no Cantinho do Céu. A residência interditada de Débora é nos fundos do $\mathrm{n}^{\circ}$. 212. Crédito: Melissa Matsunaga, 2013.

A situação de emergência deflagrada pelo auto de interdição da moradia de Débora e a demora no seu encaminhamento pelo Poder Público, mesmo com muitas ligações e visitas à subprefeitura, transformou-se no motivo de nosso contato.

A casa onde Débora morava era a última de um renque de outras cinco moradias, cujo acesso por uma escadaria era compartilhado. Apesar de todas estarem unidas estruturalmente, a única casa interditada era a dela. Ao longo da conversa, percebi uma vez que percebera que a casa 
estava numa condição de deslizamento, e ela logo entrou em contato com a associação de moradores e com uma assessora parlamentar, solicitando auxílio. Depois de um reparo realizado pela associação, ela percebeu que a casa continuava a "abrir", necessitando de uma atitude que resolvesse de fato seu problema. A vistoria que promoveu a interdição da residência pela Defesa Civil foi solicitada pela assessora parlamentar. O procedimento acabou por configurar um conflito com os vizinhos, que diante da vistoria do engenheiro englobou as demais casas. Sem entrar no mérito da interdição e sem julgar o depoimento de Débora, o que convém ao trabalho é perceber os mecanismos e recursos que a população moradora agencia para garantir seus direitos. A intervenção em curso no bairro também poderia ser encarada como uma oportunidade: dependendo da situação e anseios de cada vivenciador, almeja-se a sua consolidação, enquanto outros torcem para que sua moradia seja removida.

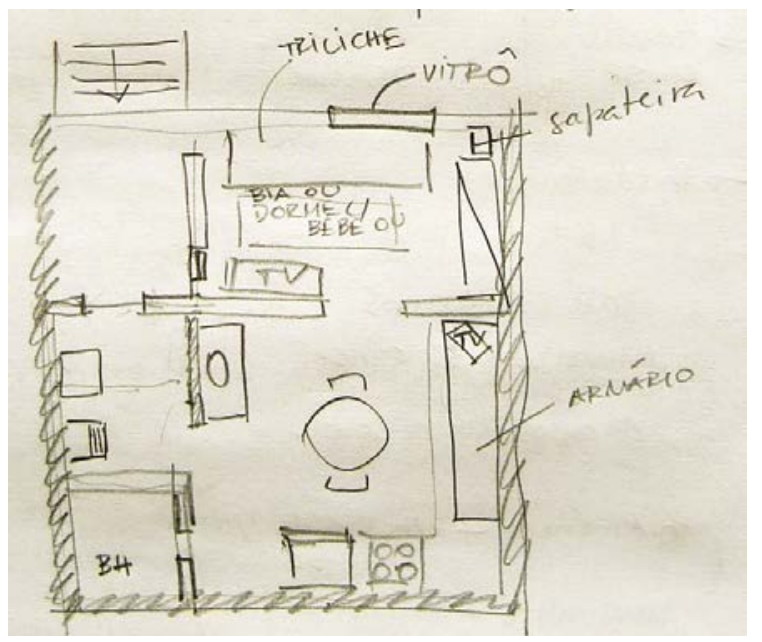

Figura 44 - Croqui de campo. Planta da casa de Débora. Elaboração: MATSUNAGA (2013).

Então é como se a casa tivesse abrindo no meio. Pra mim, no meu pensar, é como se isso aqui tivesse cedendo pra lá, entendeu? Porque eu tô vendo, tá dando mais diferença da rachadura aqui do chão. Esse lado aqui onde tá a mesa, ele já tá mais caído pra cá, pra dentro do quarto. (...) E pra mim não importa. Que eu saia pro aluguel, não tem problema. Já vi umas casinhas linda, maravilhosa, que cabia dentro do orçamento. Já foi tudo alugada aqui no bairro Que por enquanto eu não posso sair... Que nem, os apartamentos eles disseram que não vai ser mais aqui no bairro. Diz que agora é na Chácara do Conde, lá pro lado do Varginha. Os apartamentos quando sair, demora de 3 a 4 anos pra sair um apartamento desse. Então enquanto não sai os apartamentos pra eu morar definitivo, eu não posso sair daqui feito louca e alugar casa em qualquer outro bairro, tirar as meninas da escola. Final de ano, tirar de creche porque escola você consegue transferência, creche você não tem transferência. Aqui no bairro, querendo ou não, eu tenho a ONG pras meninas, é meio período que elas ficam na ONG. A ONG aqui é uma maravilha, essa ONG aqui do Cantinho do Céu. Primeira coisa que foi feita aqui no Cantinho do Céu, primeira e única coisa que tem, que presta aqui no Cantinho do Céu é essa ONG. Ela supre 120 crianças ao dia. 
Débora parecia vislumbrar seu futuro diante da interdição da casa, já imaginando o novo apartamento na Chácara do Conde, "pro lado do Varginha". No entanto, ela mesma sabia que o período em auxílio-moradia seria longo, impactando imediatamente na vida de suas filhas, que dependem de creches e escolas do bairro.

A ONG CCA Crescer, citada por Débora, fica localizada numa das antigas chácaras do bairro. Cruzando informações, corresponde à antiga chácara de Klaus e Bárbara, os mesmos que queriam a desapropriação para a mesma se tornar um centro de educação ambiental. Antes de funcionar como ONG, era alugada para festas e bailes funk, eventos que Débora inclusive chegou a trabalhar de segurança, fazendo revista na portaria, ganhando 40 ou 50 reais pela noite.

Cresci no Parque São Paulo, perto do Terminal Grajaú, do mercado Dia. Morei com minha mãe até 23, 24 anos ali. Saí da casa da minha mãe eu tinha 19 anos, morei ali nos bairros próximos mesmo, Parque São Paulo, Parque América, onde $o$ aluguel era mais barato. Quando a Bia tinha um ano e meio mais ou menos mudei pro Parque América, próximo à escola Rene Muawad. Mudei pro Varginha, a Bia estava com 2 anos completos. Fui morar perto da minha sogra, a mãe do Ivan. Ele foi preso por roubar um taxista. Nós ficamos juntos, daí fui morar no quintal da irmã dele pois fiquei desempregada e ele como expresidiário não arrumava serviço de jeito nenhum. Aí tinha um serviço na penitenciária que eles ajudavam tipo assim com uma ajuda de custo. Eles trabalhavam fazendo teatros, no antigo Carandiru, tinha um movimento lá. Então os presidiários saíam da cadeia durante o dia, fazia esse teatro e tinha uma ajuda de custo, se não me engano na época, era 180 reais. E não dava pra gente pagar aluguel. Fiz um barraquinho de madeira no quintal lá. Isso foi em 2004. Até a situação melhorar. Separei dele, voltei a morar com minha mãe. Daí fui morar no Eliana, acho que uns 4, 5 meses e quando apareceu a oportunidade de comprar aqui. Aqui era do marido da tia da Carol, Vanderlei, da minha filha mais velha. Ele me ofereceu na época essa casa por 2000 reais. A gente não tinha o dinheiro de cara para dar, isso foi em 2005, eu já estava grávida da Stephanie. Eu mudei pra cá no dia 21 de março de 2005. Eu estava com o Ivan, tinha voltado com ele. Assim que voltamos eu já engravidei. A gente fez um acordo de pagamento: a gente tinha que dar um DVD pra ele no valor de 300 reais e parcelava 1700 em 17 meses de 100 reais. Só que não foi feito escritura, contrato, nem nada. Foi de boca, como provar, não tinha. $O$ Vanderlei morava na rua aqui. Nessa época eu era registrada num empresa de limpeza em Santana, recebia 1000 reais.

Debora tem um histórico familiar tumultuado. Tem duas irmãs mais novas, sendo que não conversa com uma delas e diz não conhecer o pai, que não é o mesmo das irmãs. Ao contar sobre a família, deixa evidente um desdém:

Tenho duas irmãs. Mas só tenho contato com uma, com a caçula, sou a mais velha. A outra deu pra ser prostituta, quis matar minha mãe, depois botou uns vagabundo na casa da minha mãe. Ameaçando que tinha contratado o dono de uma biqueira pra me matar e fui descobrir que ela estava com dívida de droga e queria usar o dinheiro da minha mãe. Não conheço meu pai, nem por foto. 
Minha mãe foi mãe solteira e criou as filhas tudo sozinha. Nasci em São Paulo. Minha mãe engravidou também, meu pai arrumou outra mulher e picou o pé no mundo. Conheci os pais dele, meus avós, meus tios, minhas tias, mas não tenho contato com nenhum deles. O pai das minhas irmãs é outro. Elas são irmãs do mesmo pai. O pai delas eu cheguei a conhecer. O meu, só o primeiro nome, que é Geraldo.

Conta sobre os desamores vividos com os pais das meninas, desde Carol e Bia, cujos pais respectivos não assumiram a responsabilidade na criação, até o pai da filha mais nova, Anny Stelly, “preso recentemente por não pagar pensão, mas solto sem pagar pensão":

O pai de Carol, Farnei, namorava, engravidei. Ele não quis assumir e eu criei. Só quando ela estava com 8 anos eu botei na justiça. Pois até então eu dizia que pedir pensão era pedir esmola. Sempre fui muito orgulhosa. De uns tempos pra cá que eu comecei a correr atrás de pensão. O pai da Bia, Marcos, também, eu engravidei, um pé na bunda. Só namorava. Era burra, em vez de se entupir de remédio. O pai da Stephanie, Ivan, comecei a namorar com ele em 1999, nos separamos por um ciúmes doentio. Ele me chifrava na cara larga. Ele tem outros 3 filhos. Fiquei uns 8 anos com o pai da Stephanie, que é o tempo que eu moro aqui. Morei com ele uns 4 anos, aquele vai e volta... Fernando, pai da Anny Stelly, foi preso por não pagar pensão, mas foi solto sem pagar pensão. Hoje em dia é assim. Viciado em crack, é catador de reciclagem para sustentar o vício. Ele batia em mim.

O desentendimento com a filha mais velha, Carol, é tratado com muito ressentimento.

Segundo Débora, as desavenças com Carol agravaram seu quadro psicológico já em depressão. Além disso, quando procurou ajuda no Conselho Tutelar, sua atitude como mãe foi questionada, a responsabilizando pela má conduta da filha na escola:

Fui pra igreja, pois estava num desespero, medo de morrer, fiquei doente do coração. Por conta do nervoso que eu passava com minha filha, elevava minha pressão, comecei a ficar com taquicardia. O médico falou que faltou pouco para dar um ataque fulminante, era muito nervoso. Essa minha filha mais velha, que eu botei pra fora de casa, batia nas meninas. Eu saía pra trabalhar, trabalhava numa empresa de limpeza pós-obra. Cotia, Barra Funda. o lugar mais perto que eu trabalhei foi onde: Santana. Saía 4 h30 para trabalhar, na época ela estudava à noite e durante o dia ela estava em casa. Ela batia nas meninas e ameaçava, que se as meninas me contassem, no outro dia ela batia de novo. $\mathrm{Na}$ época ela estava com 16 anos. Agora ela tem 18, fez em agosto. Quando eu descobri que ela estava com muita falta na escola, eu fui no Conselho Tutelar pedir socorro, que eu não aguentava mais. Ela era uma pessoa muito difícil, ela batia nas meninas, e eu ia reclamar, ela achava ruim e acabava vindo pra cima de mim, eu já picava a mão na cara. Fui ao Conselho Tutelar pois sabe quando você não sabe mais o que fazer. Tá vendo que você vai perder as estribeiras? Cheguei lá, passei um belo nervoso com o conselheiro. Ele falou que tudo isso era culpa minha. Que ela não ia pra escola, descobriu que ela estava com mais de duzentas faltas e que eu que era responsável porque eu que tinha que levar ela na escola. Lá no Gaivotas! Aí eu peguei, mandei ele se lascar. Eu não vou levar uma bicha safada de 16 anos pra levar na escola e deixar uma bebê dentro de casa, na época minha bebê nem tinha 2 anos. Eu não ia levar a bonitona no Gaivotas a noite. Depois de $23 \mathrm{~h}$ eu ia voltar 
pra buscar? Discuti com o conselheiro, chegando em casa passei mal, a ambulância teve que vir me buscar porque a pressão subiu muito, vomitei, fiquei desacordada. Quando eu acordei a ambulância já estava aqui na porta. Eu não tive essa mordomia da minha mãe me levando na escola. Você quer estudar, você quer ter um serviço bom? Você vai estudar. Você não quer? Problema seu, vamos na real. $\mathrm{O}$ bairro que você mora não é um bairro que presta. $\mathrm{O}$ mundo pode te dar um monte de oportunidade. Quer ser o que presta? Você vai pra escola. Não quer ser o que presta? Vai viver sua vida. Mas da minha porta pra fora. Ela se envolveu com droga, começou a pegar as coisas dos outros, ia pros bailes funk, que tinha muito. Então ela ia pros bailes funk, usava droga, usava as bebida dela e achava que eu era obrigada a ela chegar $2,3 \mathrm{~h}$ da manhã, abrir a porta pra ela e calada. Porque se eu reclamasse ela vinha pra cima de mim. E as vezes ia pra cima da Bia. Quando eu descobri o que acontecia dentro da minha casa, eu surtei. Passei 15 dias deitada na cama. Os vizinhos começaram a contar. Aí as meninas começaram a abrir a boca pra contar, as meninas já não aguentavam mais. E ela negava. Aí eu descobri mais coisas pelo posto de saúde. Porque todo mês passa o agente de saúde nas casas. E eles relatam, tem relatório médico. E eu descobri que ela falava mal de mim para o pessoal do posto. Então, eu era a víbora, a mãe arrogante. A mãe que não compreendia a filha. Eles convocaram uma reunião na igreja católica. Eles dividem por região, aqui é a área 4 . Então os médicos que vão atender naquele dia, naquela área. Quando eu descobri, eu já estava com uma bela depressão de novo, já estava fazendo tratamento para parar de fumar, eu fumava 40 cigarros num dia. Cigarro do Paraguai. Comecei a prejudicar as meninas aqui dentro de casa, imagina eu fumando dentro de casa. Eu fazendo tratamento, com todos esses problemas. Eu surtei. Entrei em depressão, cai de cama. Fui no Conselho Tutelar, não recebi ajuda que eu merecia na hora. Porque eles vêem o lado do adolescente, não vê o lado psicológico das mães. Parei o tratamento do cigarro porque não tinha mais condições de ir lá pro São José, fiquei desempregada. E estourei a fumar mais ainda. Comecei a passar necessidade dentro de casa e os vizinhos começaram a mandar mantimento. A Carol foi morar obrigada com o pai. E agora tenho que ir no Fórum me explicar porque eu estou pedindo a pensão. Eu abri processo contra o pai dela quando a Bia tinha 4 anos de idade. A Bia tá com 14, então há 10 anos eu corro atrás de pensão à toa. Ele nunca pagou.

Ao contrário de sua relação com Carol, seu envolvimento com as outras filhas é marcado com atitudes de carinho e respeito. Inclusive recebendo os amigos de Bia em sua casa para que não fiquem no "bairro que não é bom":

Quando a Bia estava namorando vinha aqui pra casa os adolescentes do CCA. Eu e mais duas mães fizemos uma parceria do que? Você quer saber com quem seu filho anda? O bairro não é bom. Então você tem que acomodar dentro de casa. O combinado seria cada final de semana juntar 8, 10 adolescentes que é a turminha deles, escolher a casa de uma daquelas mães para ir. E o pessoal ia pra casa das outras mães? Imagina eu comportar dentro desse quarto, que você tá vendo o enorme espaço, 12 adolescentes em um dia? Eles vêm $11 \mathrm{~h}$ da manhã. Se você vem $11 \mathrm{~h}$ da manhã, você vem para almoçar, então você tem que fazer essa forminha aqui pequenininha[mostrando a forma] você faz de lasanha, essa panela de arroz [mostrando uma panela de cozinha industrial], você pega umas bacias para fazer 3 ou 4 de salada. Daí almoça e vai todo mundo deitar para poder assistir os filmes. Fiz o cadastro numa locadora, alugava filme ou 
comprava ali no camelô e passava a tarde, no chão e nas camas. E passava a tarde assistindo. Dava 6, 7 horas da noite, eu: Pelo amor de Deus, some agora todo mundo da minha casa. E as mães não estavam nem aí porque sabiam que estavam aqui na minha casa né. E eles achavam que na outra casa eles não iam ter a mesma liberdade. Agora parou porque as meninas começaram a entrar em encrenca uma com a outra, ciúmes uma da outra. Aí eu cortei. E outra, foram 4 finais de semana direto, minhas condições não são aquelas coisas. Imagina dois finais de semana que você tem que alimentar 10,12 adolescentes? E fora seu psicológico né. Eles sabiam que aqui não podia falar palavrão. Tenho que tirar minha mesa para deixar esse espaço pra eles. Querem fazer festa de aniversário e dançar. Mas daí eles escoram no meu armário, e eu grito: meu armário! minha geladeira! Mas você tem que fazer alguma coisa para agradar, não tem como.

Hoje Débora vende produtos cosméticos para se sustentar e recebe pensão de 200 reais do pai de Stephanie e 150 reais do pai de Bia, quando ele se lembra. Mantivemos contato por telefone e redes sociais, onde ela me relatava as idas e vindas à subprefeitura, cada vez com uma alegação diferente por parte deste órgão, para que seu auxílio-moradia não fosse encaminhado.
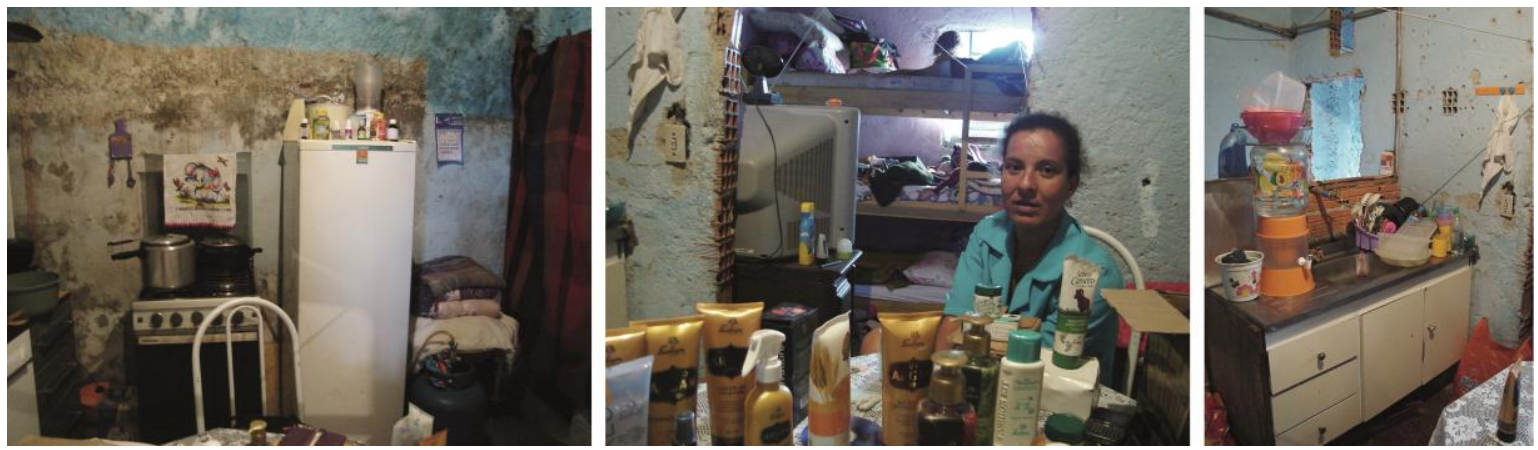

Figura 45 - Residência de Débora interditada pela Defesa Civil em junho de 2012, à Rua Porto Seguro, 212. Crédito: Melissa Matsunaga, 2013.

Mais de dois anos após o auto de interdição é que o auxílio-aluguel foi liberado, em 30 de julho de 2014. Seu pagamento é feito de três em três meses no valor de R\$1.200,00. Débora, no entanto, saiu da casa interditada antes disso. Já havia conseguido outra moradia no bairro, onde mora desde o início de 2014.
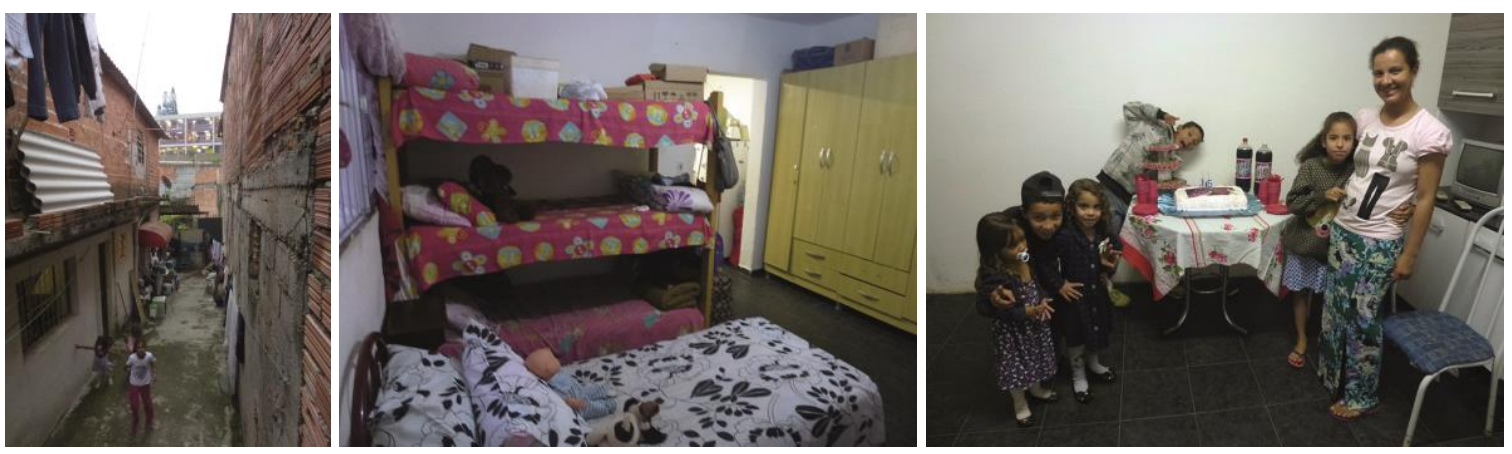

Figura 46 - Nova residência de Débora à Rua Canário. Crédito: Melissa Matsunaga, 2014.

No dia em que fui visitar sua nova moradia no bairro, era aniversário de 15 anos de Bia, e a família estava nos preparativos da festa. A nova casa localiza-se à Rua Canários, 56A e fica no 
pavimento inferior da moradia do proprietário, que o aluga para duas famílias, sendo a família de Débora uma delas. A mudança do padrão construtivo da moradia pareceu alterar os ânimos da família, ainda que em condições de vulnerabilidade, entretanto, com mais esperanças de um futuro melhor: havia um quintal pequeno para as crianças brincarem; havia revestimentos de piso e de alvenaria; os móveis eram quase todos os mesmos, com o acréscimo de uma cama e um sofá, que não cabiam na casa anterior. A festa de aniversário, cujos preparativos combinava cuidadosamente as cores preferidas da aniversariante, Bia, também restabelecia as boas vindas dos amigos à casa.
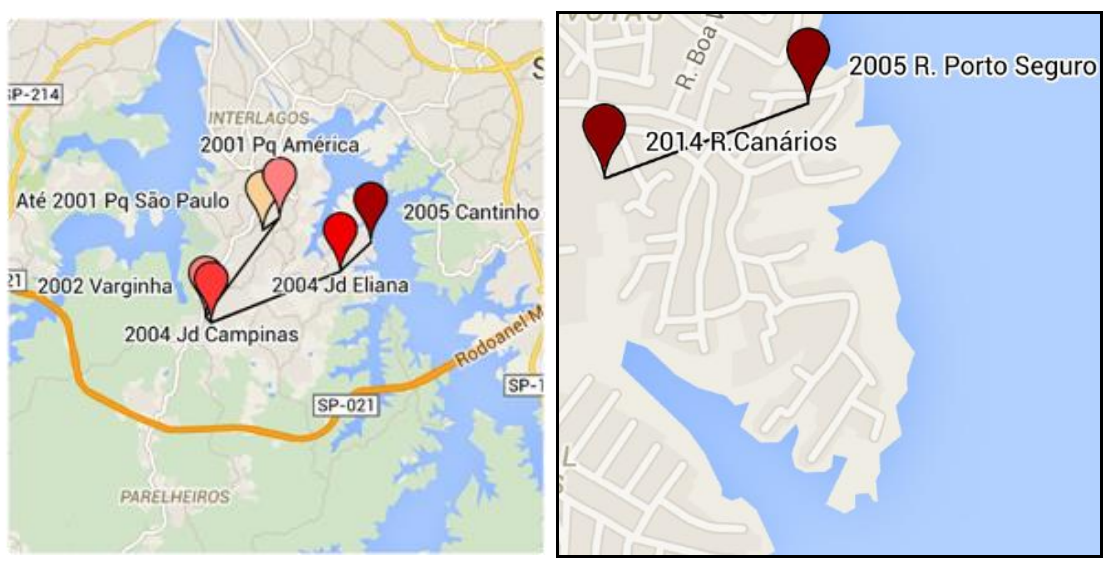

Figura 47 - Locais de moradia de Débora.

\subsection{A família CRESCE}

\section{Seo Pedro e Cleonice}

M: E o senhor não acha que vai sentir falta daqui quando mudar?

P: Acho que não devido aos problemas, problemas no bairro mesmo que eu já ralei muito aqui. A coisa já teve muito difícil então você não sente falta, quando você pega outro lugar que o ônibus é na porta, principalmente o transporte público tudo. Eu ando daqui até lá, você viu lá o ponto da lotação. Para ir a pé é longe. Então essas coisas assim. (...) Eu tenho amigos demais aqui, mas você se readapta, você tem que procurar melhoria de infraestrutura que aqui não tem.

Seo Pedro, 53 anos, mora com a esposa Cleonice e o filho Ruan, de 37 e 7 anos, respectivamente, no Cantinho do Céu desde 1997. Veio do Paraná para morar em Ermelino Matarazzo com a família aos 8 anos de idade. Antes de se mudar para o Cantinho do Céu em 1997, Seo Pedro morou em São Miguel e São Mateus. Cleonice é pernambucana de Ouricuri, e morou anteriormente em Campinas, interior de São Paulo. A moradia da família localiza-se à Rua Bonfim no 55A, área demarcada pelo projeto urbanístico para remoção.

Conheci Seo Pedro no ônibus (que o pessoal chama de lotação ou perua) em direção ao Cantinho do Céu em junho de 2013, no dia que eu agendara entrevista com Dona Lourdes do Lago Azul. Ele me indagara se eu estava perdida, falei que estava fazendo uma pesquisa e ele já de início 
demonstrou interesse em contribuir, me perguntando sobre o questionário que eu deveria aplicar. Expliquei que não havia questionário, que a entrevista era aberta e que o tema incidia sobre a história de vida no bairro. Ele me recebeu no seu dia de folga, uma terça-feira de julho de 2013, estavam em casa o filho, a esposa e a tia dela, dona Madalena que também é cunhada de Seo Pedro (o irmão de Seo Pedro é marido de Dona Madalena).

Ao chegar, percebi que ele queria saber se eu poderia dar alguma informação sobre as remoções, se a casa dele sairia mesmo. Pelo que Seo Pedro me contou, no início das obras em 2009 foi anunciada a remoção, no entanto até aquele momento nada havia sido feito. Sua rua continuava sem pavimentação e ele sem informação. Infelizmente nesse sentido eu não poderia ajudar, mas uma ida ao canteiro de obras da construtora seria uma saída.

Seo Pedro atualmente é vendedor ambulante na Barra Funda, atividade que ele inicialmente descreveu como "trabalho com produtos importados". Além disso, possui um ponto de venda na Rua Francisco Inácio Solano, na faixa da linha de transmissão de energia elétrica - local de grande concentração de barracas - que ele aluga por duzentos reais.

Ele está se preparando para a remoção anunciada. Desde que ficou sabendo que poderia ser removido, Seo Pedro começou a ir atrás de uma nova moradia. Mostrou-me fotos do novo lote que comprou em Francisco Morato, na região noroeste da RMSP, inclusive com obra da nova casa já avançada: estavam executando a laje. Ele espera ser indenizado pela construção da casa onde mora. Ele me mostrou também a primeira conta de energia elétrica, uma indicação positiva frente a possibilidade de remoção. Reclamou muito sobre a falta de informação, visto que para ele é necessário as famílias estarem informadas sobre o projeto, e isso não está acontecendo.

Já no início da entrevista, quando solicitei autorização para gravação de nossa conversa, Seo Pedro tem a seguinte fala: "Aqui a infraestrutura é precária, é esquecido pelo Estado, aqui não tem jeito não viu", fazendo questão que eu registrasse seu depoimento enunciando a ausência do Estado no bairro.

Estávamos andando pelo entorno da sua casa, que fica num lote de esquina, e ele me mostrou a edificação da casa do cunhado, cuja obra estava parada. Chegando a frente de sua casa, ele comentou sobre o lote maior que pertenceu ao pai e que fora subdividido entre os irmãos e que estes venderam os terrenos. Ficou apenas o dele e o do pai, onde agora mora a madrasta. 


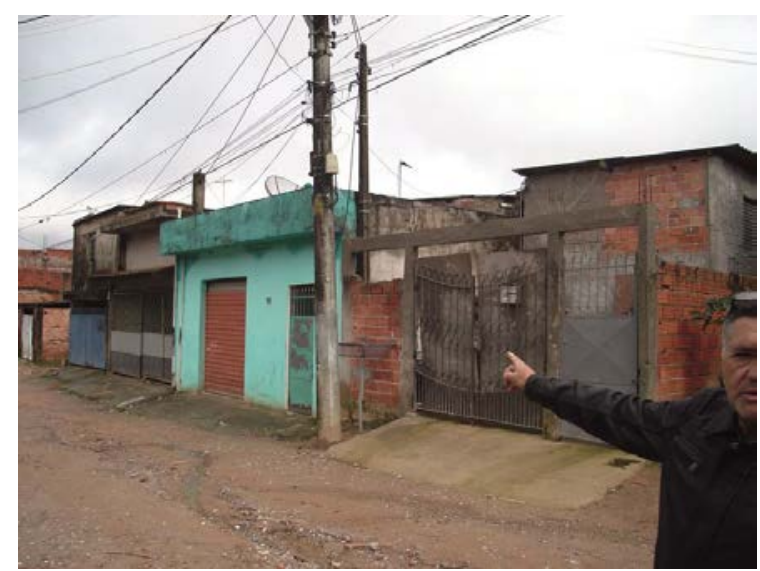

Figura 48 - Seo Pedro indicando a até onde vai o antigo lote do pai, englobando a casa verde, onde mora a madrasta. Crédito: Melissa Matsunaga, 2013.

Percebi que há duas estações elevatórias de esgoto - uma delas sem funcionamento devido ao roubo de cabos de energia. Seo Pedro comenta:

P: É... roubaram os fios, não sei como conseguiram entrar nesse buraco aí para tomar uma descarga elétrica... voltagem muito grande. Ah, o carro da segurança estava há pouco tempo aqui. Foi embora agora, todo dia eles vem.

M: E esses carros abandonados? Porque lá do outro lado a gente vê alguns jogados na margem... O senhor não sabe deles?

P: Sei. (falando baixo) É carro roubado.

M: Daí eles vem jogar aqui?

P: Joga aqui na represa. (...)

Entramos em sua casa. Não havia cadeiras para todos, apenas duas. A tia e Ruan sentaram-

se. Apresentei minhas intenções da pesquisa, que dizia respeito ao cotidiano das famílias que moravam no bairro. No entanto, o tema da remoção era mais urgente:

Foi falado que aqui seria totalmente área de remoção. As famílias seriam todas removidas. O pessoal com um jaleco da prefeitura falou que é área de remoção. Mas isso já faz aproximadamente dois anos e meio. Então você fica na dúvida: vai sair ou não vai? Eu queria uma certeza do Poder Público. Isso que é minha dúvida que paira, é a dúvida de muitos moradores. Inclusive se você tivesse acesso ao Poder Público para me esclarecer isso eu ficaria muito agradecido. Porque você não pode ficar sendo morador com aquele ponto de interrogação eternamente. E você vai lá, é evasivas. Não tem. Ah... tá parado, não sabe quando? Não é assim, não é dessa forma! Isso não é uma resposta concreta! Vai ficar ou vai tirar? Inclusive teve um vereador no tempo de eleição chamado Milton Leite, um senhor que veio aqui. Ele falou: aqui tudo é área de remoção. Quando ele veio. Mas ele veio atrás de voto, não veio atrás de... né. Inclusive esse Milton Leite, ele fez a reunião no bar. O pessoal tomando cerveja num dia de domingo. Mas na verdade ele veio atrás de voto. Só que ele esclareceu: - Por aqui eu não posso fazer nada que aqui o projeto já foi aprovado, vai ser um parque ecológico. Eu não estava presente na reunião que eu fui trabalhar no domingo. Depois que eu fui lá no bar saber. Inclusive ele deixou um mapa. Ele falou que tinha um site que você podia acessar pra ver. E disse que um juiz já aprovou pra ser um parque aqui. 
A falta de informação tem sido um dos aspectos mais evidentes do projeto realizado no bairro. As informações fluem de boca em boca, juntamente com a incerteza das intenções do Poder Público para o bairro. Senti-me impelida a contribuir de alguma forma.

- Então, vou ser bem sincera. De fato, aqui era uma área para ser removida. Eu não tenho certeza, mas onde vi que tem pavimento, talvez tenha uma adequação, mas talvez onde tem pavimento é o que fica.

P: Então onde não tem...?

- Seria mais ou menos isso. Mas eu não tenho certeza também. O que eu lembro é que essa ponta sairia.

Senti que Seo Pedro esperava informações de mim. Informações sobre o projeto, sobre as propostas apresentadas aos moradores em contrapartida à remoção.

$\mathrm{P}$ : Se você não souber responder não tem problema: eu ouvi falar que pode ser que indenizem em dinheiro e pode ser que saia esses predinho popular. E não vai dar dinheiro, vai dar um imóvel.

- Sim, na verdade é assim, cada família...

P: ...opta pelo que quiser.

- Isso, conversa e chega num acordo. A prefeitura, na gestão passada estava oferecendo tanto o pagamento pela casa, que seria uma indenização pela sua construção. Ou a alternativa de ir para um conjunto que ela estava construindo. São dois conjuntos que eu sei, mas não tenho certeza também. Não sei se eles acabaram também. E até eu queria achar pessoas que saíram daqui e foram pra lá pra saber como que foi.

P: Muitas pessoas saíram do Lago Azul, que foram desapropriadas, e ficaram nas imediações também. Não quer sair do lugar. Eu to me preparando para ir para outro lugar. Inclusive se você quiser ver as fotos.

- Ah, eu quero.

P: É em Francisco Morato. É município. É fora da capital.

- Pega o trem?

P: Pega o trem, é a última estação. Inclusive lá tem uma baldeação pra Jundiaí. Ó, desde quando comprei o lote (me mostrando as fotos).

- Qual é o tamanho do lote?

P: $5 \times 25$.

Seo Pedro me mostrou as fotos do novo terreno e da obra em construção. Percebi que o lote no município de Francisco Morato, quase 75Km de distância do Cantinho do Céu, era em declive.

P: Aqui era uma trilha do pessoal passar né. Bairro novo, mas tá enchendo de casa. Tem toda infraestrutura.

- E o senhor disse que tem escritura?

P: Tem.

- Mas tem a escritura mesmo ou é compromisso de compra e venda?

P: Não. É assim. Tem compromisso de compra e venda para tirar a escritura.

-: Sim.

P: Eu não tirei porque eu não tenho o dinheiro...

- ... para pagar o cartório?

P: É, pra pagar tudo. Tá 1.980. Mas já tá quitado pra tirar a escritura. Esse final de ano que a renda melhora eu vou tirar escritura. No dia que comprei o lote tirei 
uma foto com a mulher, ó, o menininho era menorzinho.. Um ano e meio atrás, dois anos Cleonice, nós tem lá?

C: Acho que tem mais de dois anos.

P: Dois anos aproximadamente. (...) Aqui é o vizinho, aqui tinha uma árvore. É caído para trás.

- Mas é bem inclinado aí também né?

P: Eu contratei essa retroescavadeira. E a caçamba aqui. Ia enchendo de terra e tirando, para aplanar né. Tem vizinho à esquerda, à direita e nos fundos. Ele estava vago esse lote.

- Então todos os vizinhos já construíram? Só falta o seu?

P: Fiz a terraplanagem né. Já tiraram a terra. Eu e meu cunhado, irmão dela, fizemos a fundação também.

- Ah, o senhor é pedreiro?

P: Não. De tanto eu pagar mão de obra aqui eu aprendi sozinho. Inclusive tem um condomínio fazendo na frente do meu terreno, os caras queriam me contratar de pedreiro. Pensa que não? Eu só trabalho pra mim. "Não, que tá saindo muito boa. Nós estamos contratando pedreiro, se você quiser traz sua carteira de trabalho" Eu disse não, não, to fazendo essa pra mim morar. Ó, eu me meu cunhado fizemos desde a fundação né. (me mostrando fotos da obra)

- Hum, a viga baldrame. Mas vocês fizeram broca embaixo né?

P: Broca e uma sapata bem grandona assim... Porque é área de barranco. Não tem como, você tem que gastar e fazer certo.

- Super caprichado mesmo. To vendo a alvenaria...

P: Aqui no fundo, como é porão embaixo. Bateu laje, e aqui tem que ser tijolo mais leve, em cima.

- E como está a ligação de rede de esgoto?

P: Então, lá não tem esgoto. Fiz uma fossa de $4 \mathrm{~m}$.

- No fundo do seu terreno? Porque o caimento está pra dentro do lote né? Mas era para ter esgoto, ou não? Não tem asfalto na rua?

P: Sim. O ponto de ônibus é na porta assim.

C: As ruas são bem largas.

P: Aqui as paredes respaldadas. Trabalhei muito lá. Aqui é o porão. A construção veio daqui pra cima. Aqui tem uma igreja perto.

M: O senhor é evangélico?

P: Não, sou católico. Mas nada contra. O universo para todo mundo. O sol brilha para todos.

Encerrando o álbum de fotos da nova construção, Seo Pedro retoma o assunto da remoção

e o quanto isso paralisou seus planos de reforma da casa enquanto outros moradores "não estão nem aî":

Aqui é um ponto de interrogação, que nem eu te falei, eu tenho que pensar no dia de amanhã. Tenho família. Antes, queria ficar aqui, bater laje. Tá vendo aqui é de brasilit, ó. Como falou é área de remoção. Daí eu fico nessa, nunca quis dar os acabamentos na casa. E tem gente por aí que tá aplicando muito mais nas casas... continuando, não tá nem aí. Cara sem instrução que não se preocupa em ir lá, correr atrás do Poder Público. Vai investindo, vai gastando. Tenho um amigo ali que tá gastando. Ele falou assim, "meu isso aqui não vai sair mais ninguém. Esquece.. já ligou esgoto". Não é assim, a gente sabe que não é assim. Você vai falar com a pessoa, a pessoa não te ouve... 
Seo Pedro lembra como era o bairro quando se mudou e as transformações pela quais passou, com a infraestrutura de água realizada pelos próprios moradores e as ligações clandestinas de energia, que segundo ele "era gato por baixo e por cima":

P: Eu separei da primeira família né. Eu vim morar de favor naquela casa onde guardo meu carro, onde eu te mostrei que meu falecido pai morou. Na casa verde. Aí, quando ele faleceu, aí falou, vamo vender tudo aí. Ficou esse pra mim. Não, quando ele faleceu eu já tinha construído aqui. Já tinha bastante casa. Um pouco menos, mas já estava praticamente todo ocupado, todos os lotes. Pra eu não falar que não teve melhoria, teve, porque o gato da água era horrível. Nós mesmos cavamos, pegamos da rede e trouxemos a água. Era horrível, estourava cano. Tanto que vinha o carro da coleta de lixo e estourava o cano. Tem, tem melhoria. Coisa que veio foi a coleta de lixo aqui na porta. Coleta de lixo pra mim é muito bom. Não vai mais lixo na represa... Aproximadamente em 2010 foi que chegou água encanada. A luz tá fazendo 60, 40 dias que veio a primeira conta. Era gato por baixo e por cima. A água por baixo e a energia por cima. A água vinha da Rua Salmo. Vinha até ali e dali nós puxamos o gato, da Rua Salmo pra cá. O povão comprou os canos e ligou. Dividiu a conta do cano e cada um puxou pra sua casa. A energia, inclusive quando 40,60 dias, quando estava colocando os relógios, ligando a luz certinha, a Eletropaulo trabalhando deu um problema aí, queimou micro-ondas meu, quase queimou a geladeira. Mas é assim, faz parte. Melhorou muito com a energia elétrica. Vou te mostrar a conta.

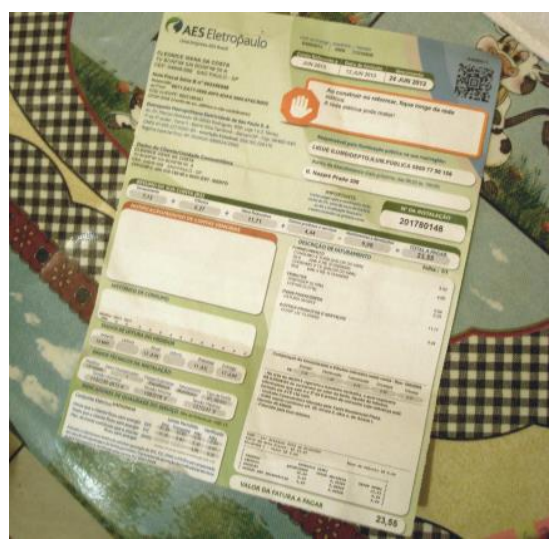

Figura 49 - Primeira conta de luz de Seo Pedro, de junho de 2013, no valor de R\$23,55. Crédito: Melissa Matsunaga, 2013.

Ao me mostrar a conta de energia, o indaguei se não era um bom sinal da consolidação daquela área. Ele respondeu sem muita conviç̧ão: “É bom. Vamos torcer né. Mas então, é uma dúvida que paira. Sabe por que não confio? Porque na Rua Cairu chegou rede de esgoto e tudo e mesmo assim eles tiraram o pessoal".

A chegada das melhorias de infraestrutura de saneamento e energia elétrica, por outro lado, criou condições para o adensamento na área, mesmo delimitada contraditoriamente para remoção. As necessidades pelas quais passavam o cunhado de Seo Pedro e a demora na consecução das remoções anunciadas na parte do bairro onde mora, fez com que o morador auxiliasse o cunhado na construção irregular, com o intuito de aliviá-lo do pagamento do aluguel: 
O meu cunhado, nós começamos a construir a casa dele aqui, essa casinha aqui atrás. Ele separou da esposa e estava sozinho. Eu falei: - Não, nós faz uma casa aí rapidinho. O aluguel, não tinha condições financeiras. Fizemos mutirão, que eu tinha uma certa amizade na vila né, muita gente, aí estava aproximadamente 6 pessoas fazendo aí né? Aí chegou a assistente social: - Isso aqui tá embargado, não pode ser construído mais nada aqui. Aí meu cunhado ficou triste, chateado né, que as paredes já tavam dessa altura, aproximadamente 2 metros né. Aí passou 6 meses não veio mais ninguém, eu falei: - Marcos você tá no sufoco mesmo, vamos fazer, se você passa um ano sem pagar aluguel já melhora. Que se lasque, vou falar o português bem claro, se lasque o Poder Público, você tem que sair do sufoco. Essa é a realidade. Aí terminamos as paredes, respaldamos, colocamos as telhas de brasilit, já colocamos piso cerâmico. Ele tá aí até hoje. Já faz um ano e meio... Arriscar né, vai fazer o quê? [...]Isso que eu queria saber: se eu vou sair? Isso aqui é área de remoção ou não? Eu queria.. ah é área de remoção e a data estipulada? Até quando? Eu queria saber essas coisas. Queria ser esclarecido, só isso. Você fica, não investe... Era para quebrar essas paredes tudo aí, bater laje aqui tudinho. Fazer umas colunas mais fortes, um vigamento mais forte, estruturar a casa mais. Isso aqui eu comecei a moradia com ela aqui né. Ali já tem laje, ali já tem a estrutura melhor (mostrando a parte do quarto e do banheiro), daqui pra lá foi feito depois. Aqui foi no começo. Dava para quebrar os cantos, reforçar tudo. Mas quando que eu vou mexer? (...)

Tentei retomar a conversa que tivemos na lotação no primeiro dia, quando Seo Pedro demonstrou sua atitude em resolver sua situação comprando outro lote, em outra cidade, diante da demora das obras, revelando total discernimento quanto aos interesses públicos em jogo com as obras. Contudo, o bairro também é violento, aspecto que deveria ser enfrentado pelo Poder Público, na opinião do morador:

- O senhor falou uma coisa interessante aquele dia na lotação que foi: 'se todo mundo pensasse que nem eu'. O senhor acha que a maioria das pessoas aqui teria condições de conseguir outro lote legalizado?

P: Alguns sim, outros não. Mesmo que compre à prestação, vai fazendo um planejamento a longo prazo, juntando moedinha por moedinha. Eu já economizava antes. Aqui é cheio de problemas né, esquecido pelo Estado, pelo Poder Público né. Veio essas melhorias aí porque arrecada. A Sabesp é dinheiro que entra né... a Eletropaulo... não tem interesse em deixar gato né... quantos mil litros de água eles perdem né... mas o Poder Público não cuida da violência né, o Poder Público nunca asfaltou, não faz nada. Eles sabem aqui como que é.

O filho Ruan estuda no CEU e brinca com o pai dentro de casa mesmo. Ruan diz que não dá pra jogar bola na rua, "só nas folhas que dá". Folhas como alusão à grama, ou ao mato, já que a rua é de terra e inclinada.

- E tem mais parente de vocês por aqui?

P: Aqui não. Em SP tem bastante, mas espalhado. Tem o irmão dela em Itaquera...

C: Tem outra tia que mora em São Bernardo, irmã dela...

P: Eu tenho meu irmão que mora aqui no Lago Azul.

C: A casa deles não tiraram né. Ele gosta de lá que ele viu que valorizou. 
P: O imóvel valorizou. Ele tá feliz lá do jeito que ficou.

- Ele tá feliz? E ele é casado?

$\mathrm{P}$ : Ele é casado, tem esposa e uma filhinha deficiente.

- E ele usa o parque?

P: Ele não usa porque o povo é muito noia, muita gente usa droga lá. Ele é medroso...

C: Fica assustado né.

P: Eu usaria.

C: Quebram a lixeira, é muito vandalismo.

- E vocês acham que não é possível um parque aqui mantendo as casas?

P: Possível é, mas acho que a segurança pública esteja junto também né. Instale câmeras, que o povo de bem, que trabalha, paga imposto, tenha o direito de circular livremente, não ser tomado por vândalo. O problema lá daquele parque é segurança pública.

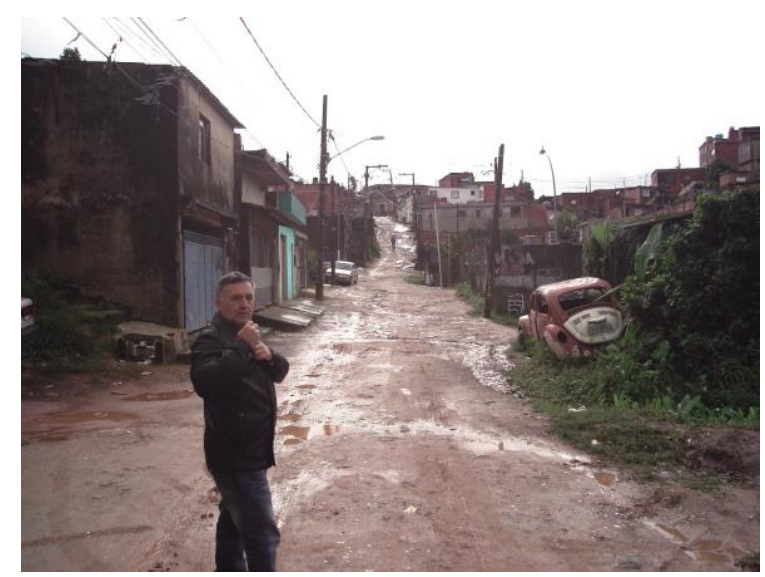

Figura 50 - Rua Bonfim na altura da casa de Seo Pedro. Crédito: Melissa Matsunaga, 2013.

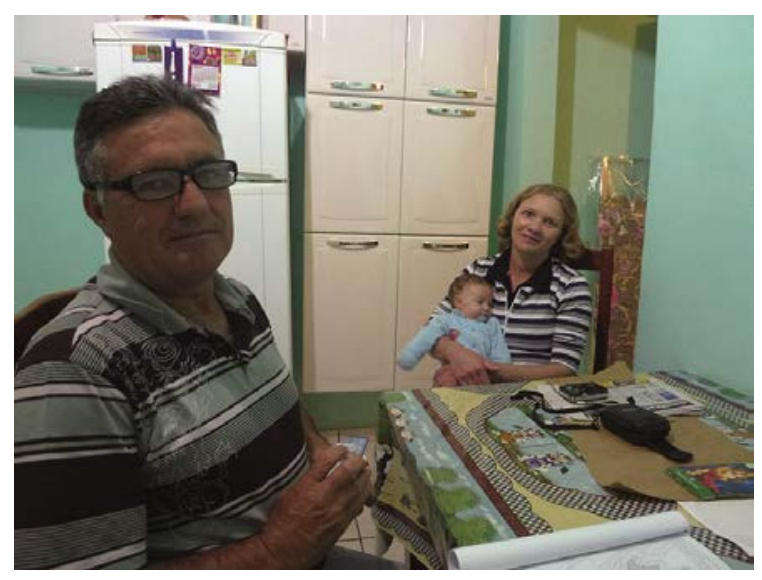

Figura 51 - Seo Pedro, Cleonice e o bebê Fabrício, que nasceu em 2014, durante o período da pesquisa de campo. Crédito: Melissa Matsunaga, 2014.

Mantive contato com Seo Pedro por telefone, inclusive quando foi Natal de 2013 ele me ligou para me desejar Boas Festas e dizer que Cleonice estava grávida. Retornei para visitar Fabrício, que nasceu no meio do ano de 2014 e, nessa visita, Seo Pedro dizia continuar sem confirmação sobre o projeto. Alguns meses depois ele me ligou dizendo ter certeza sobre o destino de sua casa, e que o vereador Milton Leite havia distribuído um material no bairro que confirmava a informação. Não demorei em visitá-lo novamente com o interesse de ver tal documento e tive uma surpresa: Seo Pedro estava com uma cópia do último volume do processo judicial da $\mathrm{ACP}$ em mãos, que tratava sobre a assinatura do Termo de Ajustamento de Conduta em relação ao projeto anexado. Nesse dia, Seo Pedro me informou que havia colocado sua casa à venda numa imobiliária pelo valor de 55 mil reais. Sua obra em Francisco Morato estava quase finalizada, e desde que obteve a cópia do processo judicial, suas perguntas foram respondidas. Seo Pedro vendeu a casa do Cantinho do Céu no início desse ano de 2015. 


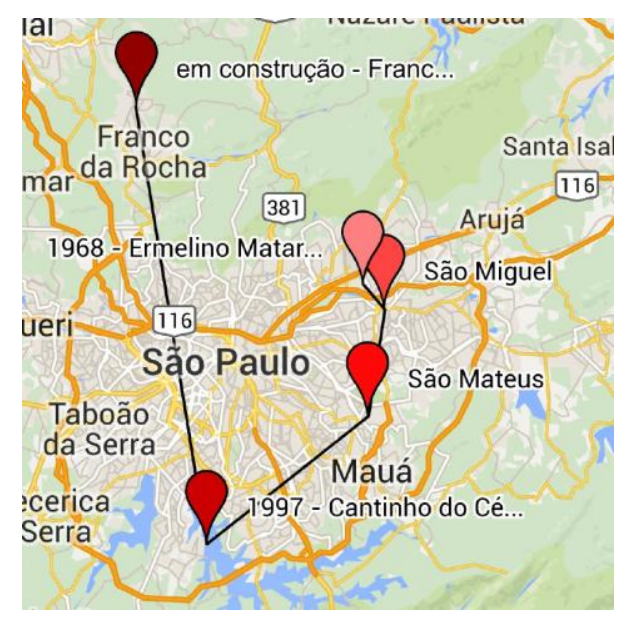

Figura 52 - Locais de moradia de Seo Pedro.

\subsection{INFORMAC̣ÃO BREVE E SILENCIADA}

\section{Eunice e Carlos 72}

Eunice e Carlos tem dois filhos, Eric de 9 anos e Everton de 2 anos. Eunice é gerente de um restaurante na Granja Julieta e tem 37 anos. Carlos é taxista, trabalha em dias alternados e tem 34 anos. Eles moravam no Lago Azul desde 2003 e foram removidos pelo projeto de urbanização em 2009. Moram atualmente no Cantinho do Céu e a entrevista basicamente ficou restrita ao tema da remoção. O contato com o casal se deu mediante intermediação da vizinha, Lucia (Item 3.1 deste Capítulo), que relatou que fora a prefeitura que indicou a casa ao casal. Logo quando cheguei, me apresentei contando a estratégia de campo, indo pelos contatos dos próprios moradores e explicando os objetivos da pesquisa. Foi uma entrevista lacônica, sem muitos desdobramentos das respostas e suas histórias. Apesar do intermédio de Lucia, a brevidade das palavras indicou um sentimento de desconfiança em relação ao que eu estava fazendo ali, perguntando sobre suas intimidades.

A remoção fora o motivo principal de eu ter chegado até eles, e percebendo o desconforto não só meu quanto do casal, destaquei dois pontos de interesse, ambos relacionados à desinformação. Primeiro, sobre o projeto de intervenção e os reais motivos de remoção e, posteriormente, sobre as alternativas de atendimento, o que poderia ter alterado a decisão tomada. A negligência de informação acabou por incentivar o procedimento de compra do imóvel em detrimento ao atendimento com bolsa aluguel. O auxílio moradia, como já visto na narrativa de

\footnotetext{
72 Nomes fictícios.
} 
Débora (Item 3.2 deste Capítulo), os colocaria na fila para obtenção de uma unidade habitacional construída em outro local, o que era ignorado pelo casal.

- E como que foi essa mudança?

C: A mudança foi a remoção né. Tiraram de lá e a gente achou aqui.

- Ah, vocês que procuraram a casa?

C: Foi.

- E vocês chegaram a procurar em outro local?

C: Não.

- Vocês queriam ficar por aqui?

C: Sim.

- Entendi, e daí o pessoal pagou a casa de vocês lá...

$\mathrm{C}$ : $\mathrm{E}$ a gente comprou aqui.

- Não foi intermediada pela prefeitura a compra desta casa aqui?

C: Não. Foi pela obra né.

- Pela empreiteira? Mas eles que sugeriram essa casa para vocês?

C: Não. Eles mandaram a gente escolher uma casa.

- Entendi, e foram eles que compraram essa casa?

C: Não. Eles deram dinheiro e a gente comprou.

- Mas eles deram pela venda da casa de vocês lá? É isso?

C: Exato.

- E esse dinheiro deu para comprar aqui?

C: Deu para comprar aqui.

- Não precisou inteirar?

C: Não.

- E vocês podem me falar o valor que foi?

C: 35 na época.

- 35 mil? A casa era boa então né?

Pela primeira vez na conversa Eunice responde:

E: É.

-: E aqui vocês pagaram o mesmo valor?

C: O valor de 35... Só que na época minha irmã morava lá também e teve uma negociação bem séria com minha irmã né. Minha irmã morava nos fundos, com um banheiro. Minha irmã começou a correr e pagaram 5 mil pra ela.

- E ela tá onde?

C: Ela tá na zona norte. Tá com a minha mãe.

- E ela morava sozinha, sua irmã?

C: É sozinha.

E: No cômodo de baixo. Que ela tinha separado né.

- E desde quando vocês moravam no Lago Azul?

C: Desde 2003, 2002... por essa época mais ou menos.

E: Eu estava grávida...

A alternativa trabalhada pela prefeitura - a compra de moradia assistida - e o procedimento de transferência de recursos foi descrita por Carlos:

- E foi tranquila a negociação com a empreiteira, com o pessoal da obra?

C: A negociação foi tranquila. Eu só não gostei da... como se diz... porque no caso eles só me pagavam lá, aqui... Eles me deram o caminhão para mudar e aí só 
pagou aqui quando eu saí de lá. Eles fizeram o pagamento em meu nome no banco. Aí eu fui com o dono da casa aqui, como era o mesmo valor da casa né. Fui no banco com ele, fiz a transferência e daí ele também já tinha que sair para eu entrar. Só isso que eu achei meio...

- Mas e quem morava aqui?

C: Aqui era um senhor, ele foi embora antes da gente comprar aqui. Ele já tinha ido embora para o interior.

E: Aqui estava fechado.

Perguntando sobre as alternativas de atendimento, Eunice disse desconhecer a possibilidade do apartamento:

- Vocês tiveram que sair? Foram forçados a sair, não tinha muita escolha? E: É, ou saia ou...

- Mas a prefeitura ofereceu apartamento ou não pra vocês?

C: Não ofereceu não. Ofereceu um tal de aluguel.

- Então, mas o aluguel era até o apartamento sair.

C: Onde que é isso aí?

- Chama Mata Virgem.

E: Já saiu? Já tem gente morando?

- Já tem gente morando. Porque foi entregue. Quando vocês saíram de lá? Que ano que foi?

C: Em 2009. As primeiras remoções foram lá.

E: Foi tudo muito rápido. Eles foram, olharam, e aí chamaram a gente pra conversar. E daí já mandaram a gente procurar casa... Foi tudo muito rápido.

- Vocês não sabiam que poderiam sair? De repente chegaram fazendo a obra?

C: Não, nem tinha começado a fazer obra ainda.

E: Era só quem morava perto da represa.

- Mas foi explicado para vocês o porquê que vocês iam sair?

E: Ah, eles falaram. Estava perto da represa, os mananciais né. O Programa Mananciais que tinha projeto pra fazer ali, e que era perigoso ficar perto da represa. E que tinha que sair sim.

Ao fim, fiquei na dúvida se as "desinformações" das alternativas de atendimento e dos motivos de remoção foram escamoteados no processo ligeiro da negociação com a equipe social, ou no processo desconfiado da entrevista. De qualquer modo, ambos - tanto a negociação quanto a entrevista - não tiveram muito envolvimento, sendo que se deram de maneira superficial, porém objetiva. Assim como foi o processo da remoção, foi a entrevista: com respostas breves e desconfiadas. Agradeci a oportunidade da entrevista e me retirei. 


\subsection{Mudança de Padrão \\ O Conjunto Residencial Mata Virgem}

O Conjunto Residencial Mata Virgem ${ }^{73}$ foi construído concomitante às obras de urbanização do Complexo Cantinho do Céu, com obras iniciadas em 2009 e sendo entregue às famílias em outubro de 2012. O conjunto habitacional, que é dividido em três condomínios, fica localizado junto à divisa do Município de Diadema, no Jd. Eldorado, em APRM-B na margem oposta da represa, e tinha como objetivo receber 407 famílias removidas pelo Programa Mananciais, não apenas do Complexo Cantinho do Céu.

A área na qual se encontra o conjunto residencial é próxima de outro perímetro de intervenção do Programa Mananciais (Jd. Eldorado), que removeu em 2011 moradias em áreas de risco. Essa área, denominada Morro dos Macacos, ganhou destaque na mídia devido à ocorrência de deslizamento de terra na execução das obras de contenção geotécnica, ocasionando duas mortes.

O novo conjunto residencial recebeu, conforme lista de atendimentos, 72 famílias do Complexo Cantinho do Céu, sendo 27 oriundas do Lago Azul. Consegui o contato de Lucilene através da equipe social do Programa Mananciais da SEHAB/PMSP e realizei apenas uma entrevista com a ex-moradora do Lago Azul.

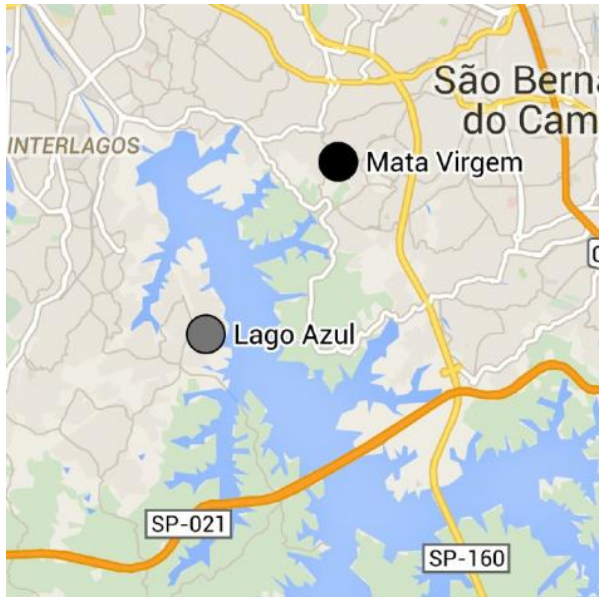

Figura 53 - Localização do Residencial Mata Virgem e bairro Lago Azul em APRM-B.

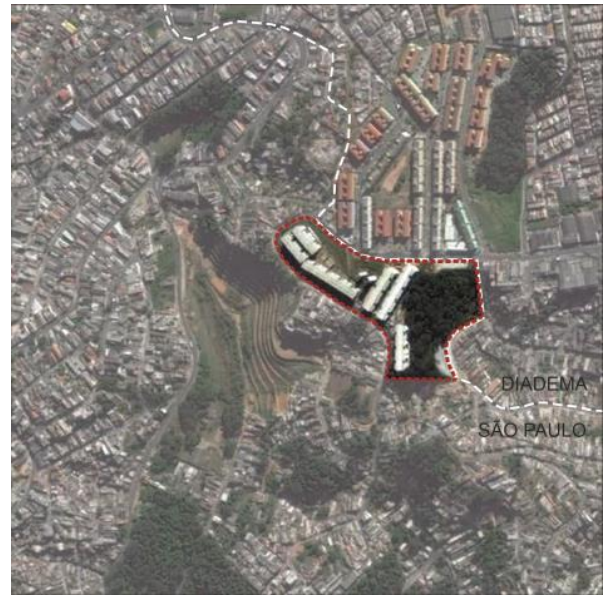

Figura 54 - Localização do Conjunto Residencial Mata Virgem junto à divisa de Diadema. FONTE: Google Earth, 2014. Elaboração: MATSUNAGA (2015).

\footnotetext{
${ }^{73}$ Informações sobre o projeto, de autoria de JT Arquitetura, podem ser consultadas nos seguintes sites: www.tabitharquitetura.com/ e www.galeriadaarquitetura.com.br/projeto/jt-arquitetura_/conjunto-habitacional-mata-virgem/1064. Acesso em 01 set 2014.
} 


\section{LUCILENE}

O que é que o condomínio tá querendo ensinar pra nós? Não to chamando ninguém de burro, mas tá querendo passar uma educação além daquela que a gente já tem. Pra gente aprender mais um pouco como é conviver com muita gente num outro padrão de vida. Como convivem os ricos. A gente é pobre porque somos assalariados, mas não somos diferentes dos ricos. $\mathrm{O}$ rico tem um pouco de dinheiro, chega lá e compra tudo à vista. Só que tem rico que fala que o pobre é mais feliz do que eles: não precisa andar com segurança, compra o que quer, faz o que quer. Embora seja tudo à prestação, mas tá sempre sorridente. $\mathrm{O}$ rico não é feliz.

Maria Lucilene Santos da Silva tem 40 anos, quatro filhos: Daiane de 21 anos, Lidiane de 19 anos, Carlos Vinicius de 15 e Gleideson de 9 anos. Está grávida de 7 meses de uma menina ${ }^{74}$. Nasceu em Barreiros, Pernambuco, e veio para São Paulo em 1985 com 9 anos, acompanhada da mãe, padrasto e os oito irmãos. Morou com a família num barraco na Vila Joaniza até os 15 anos, onde reiterou várias vezes durante seu depoimento que dormia em folha de jornal, cuja condição esperava que seus filhos não precisassem passar. Mudou-se com a família para a Rua Guaicuri, na Vila Missionária, no bairro Pedreira, onde morou por 13 anos:

Eu tinha 15 anos quando conheci o pai dos meus filhos maiores. Fiquei noiva com 17. Nessa época morava na Vila Missionária. A primeira casa que eu construí com esse rapaz foi em cima de um córrego na Vila Missionária. Era uma casa pequenininha, humilde. Toda vez que chovia na Rua Alexandre Kipnis, a água invadia minha casa, que era em cima da tubulação. (...) Foi quando eu mudei pra casa da cunhada do meu ex-marido, da irmã dele na Rua Canário Belga.

A Rua Canário Belga localiza-se no Parque Residencial dos Lagos, próxima à margem da represa. Logo após a mudança para o novo bairro, Lucilene e o marido compraram o terreno vizinho de fundo da cunhada, aproximando-se ainda mais da água da Billings. Conta que já havia uma pequena casa: "esse terreno, que tinha um cômodo de bloco, meu ex-marido comprou de uma moradora. Aí a gente comprou esse terreno, mas o pessoal chamava a gente de invasor, que a gente tinha invadido o terreno". Relata que na primeira casa que morou no Lago Azul, situada à Rua Canário Belga, 81, havia um olho d'água e sempre que chovia, entrava água na casa. Mostrou-me um foto tirada pela irmã que retrata a antiga situação onde morava e que se repetia como na Vila Missionária.

\footnotetext{
${ }^{74}$ A entrevista foi realizada em 16/08/2014, quando Lucilene estava grávida de 7 meses de Stephanie.
} 
Conta como o Parque Residencial dos Lagos era quando ela se mudou: "quando eu mudei para esse lugar, os ônibus ainda não subiam no Jd. Eliana, era tudo no Grajaú. A gente não tinha água canalizada, era tudo água de poço. A energia era improvisada nos postes de madeira”.

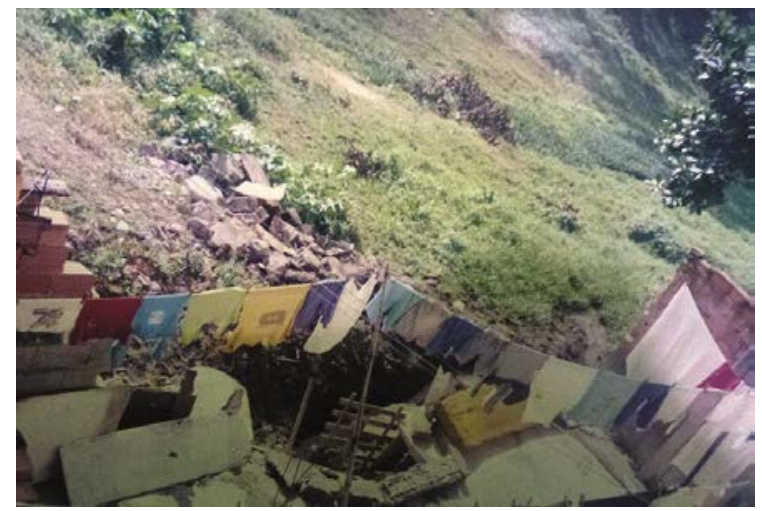

Figura 55 - Quintal da casa removida no Lago Azul. Acervo de Lucilene.

Relatou também as circunstâncias de sua remoção, que segundo ela, foi a primeira a ser retirada pela intervenção, já que estava numa condição de risco, e dado o contexto de vulnerabilidade física da sua moradia, atribui ao Poder Público a sua salvaguarda:

Meu ex-cunhado construiu na frente, e eu construí no fundo. Só que nessa época a chuva foi tão forte, tão forte, que ela estourou no meio do quintal e fez aquela abertura de água. Aí vinha água da avenida, água de todas as ruas, da Falcão Negro, só não sei a outra detrás. Aí descia tudo pra lá. Aí a minha casa tinha um olho dágua por baixo, onde eu construí um muro na beira da represa. Daí no muro tinha assim aquele olho dágua. Aí devido ao impacto da chuva grossa e a mina dágua que tinha, quando a água invadiu a minha casa ela rachou as 12 sapatas da casa, e a outra casa que tinha em cima. (...) Na segunda-feira, quando eu fui fechar a janela, eu tomei um choque da chuva. Na terça acordei com água no joelho. Na quarta que eu vi eles. Aí fechou o tempo, eu falei, não vou ficar aqui. Quando foi 11h da manhã a assistente social encostou: a senhora tem até quinta-feira para arrumar uma casa para sair daqui urgente. Foi o tempo que a prefeitura arrumou o caminhão e tudo; depositaram meu dinheiro o mais rápido que puderam para pagar o aluguel. Quando a prefeitura encostou o caminhão lá e tirou a minha mudança, e eles chegaram no outro dia para demolir a casa, foi o tempo que caiu o muro para trás. Se não tivessem me tirado de lá, eu garanto para você que eu não estaria viva com minha família.

Morou nesse local até 2009, quando foi removida. Após a saída, ela tinha duas opções, receber o pagamento de 15 mil reais ou receber a bolsa-aluguel pelo prazo máximo de 4 anos, conforme prometido pela assistência social, e assim ficar na fila do apartamento. Ela decidira pela bolsa-aluguel, uma vez que o ex-marido requeria sua parte na indenização: "Não, não vou pegar o dinheiro porque meu ex-marido já falou que se eu pegar o dinheiro que a prefeitura me der pra comprar a casa, vou ter que dividir com ele. E o que eu ficar, vou comprar o quê? Como minha casa estava praticamente dentro da represa valia só 15 mil”. Ela e o ex-marido já não estavam juntos na época da remoção: 
Quando a prefeitura passou fazendo a tubulação, ele não estava mais morando comigo. Ele não fala comigo porque agora ele é casado, mora lá no Cantinho do Céu. Tanto que hoje em dia a mulher dele afastou ele dos filhos. Ele não fala comigo porque ele tem raiva, porque mesmo assim ele queria fazer parte do apartamento. Mesmo ele tendo a casa dele, a vida dele lá, mas ele queria fazer parte daqui. Como ele não tem força maior sobre o peixe grande que tá sobre mim, que é a prefeitura, aí ele não consegue entrar na justiça pra lutar por nada.

Assim, com a verba da prefeitura no valor mensal de 450 reais, morou numa casa de aluguel no próprio Parque Residencial dos Lagos, à Rua Andorinhas Brasileiras, nº 31, onde permaneceu até outubro de 2012, quando se mudou para o Residencial Mata Virgem, no Jd. Eldorado.

A adaptação ao novo modo de viver exige a organização coletiva, com regras e normas de conduta. Algumas vezes, ela sente sua liberdade cerceada, com a presença de fofocas ou de seus filhos, quando outros moradores reclamam deles no playground:

Agora, o que eu to revoltada aqui nesse condomínio é o seguinte: os pequenininhos não pode brincar de dia e os grandes podem ficar zuando à noite? Aí os moradores desse lado aí começam a reclamar. Aí eles chamam a gente de favela? Então o que a favela tá fazendo perto do Morumbi? ${ }^{75}$ A minha revolta aqui só é essa, que meu filho não pode brincar. (...) Por isso que tem muitas mães revoltada aqui dentro, desanimada pra morar aqui, porque paga o condomínio e os filhos não tem direito de brincar. Tá criando nossos filhos em cativeiro? Criança tem que ter liberdade, tá na fase de crescimento. Chega final de semana, tem que brincar mesmo. Como eu vou manter ele aqui dentro do apartamento? Quando ele quer jogar vídeo game ele joga, mas chega uma hora que dá um tédio e ele vai descer. Eu mesma, dá hora que dá um tedio e a gente desce aqui pra baixo, agora não que eu to grávida, mas na época de calor, a gente costuma se reunir com as próprias vizinhas, tomar latinha de cerveja, faz uma vaquinha. Ou às vezes a gente vai pra frente da portaria, mas já tem gente: 'Nossa, os pé de cana tão tomando uma cerveja'. Sabe, tipo assim, eu fico com inveja de tudo o que você faz? Você tem amiga, toma cerveja, divide os belisquinhos, rindo e brincando, mas parece que você tá me incomodando? Aqui é assim. Esse é o defeito. Que nem um morador falou: 'Ainda não caiu a ficha que o pessoal mudou de vida'. Tem gente que ainda carrega a favela no pensamento. Carrega ainda aquela moradia que pode brincar, pode correr, pode gritar, fazer o que quer, entra quando quer, pode soltar os cachorros latindo, a porta do barraco aberta. Então tem gente que esqueceu que tá em outra moradia. Tem muita gente que não tá adaptando aqui nesse condomínio por causa disso.

Além de o condomínio requerer de Lucilene não apenas adaptação ao novo modo coletivo de convivência, também solicitou sabedoria para lidar com disputas oriundas da insuficiência de apartamentos para atender a demanda de remoção do Programa Mananciais. Se no Residencial dos Lagos recaía sobre ela e a família o estigma de invasores, ainda que tivessem pagado pelo lote onde

${ }^{75}$ Alusão à favela de Paraisópolis que fica no Morumbi, bairro de alto padrão residencial e alta renda. 
moravam, no novo condomínio sua presença era questionada devido ao fato de que havia moradores removidos do próprio bairro reivindicando o direito ao mesmo:

Como a gente é novo morador... Eles ali não, já eram daqui. Do 1008 também um pouco já era daqui. Aquele pessoal já morava aqui, quando tiraram as favelas, foi quando teve o desastre. (...) A maioria veio pra cá, tanto que, quando a gente veio morar aqui, teve morador que tá há quase 5 ano no bolsa aluguel, e eles falaram que era para eles estarem morando aqui, e não a gente. Mas a gente não tem culpa. Então se for analisar, ficamos 3 anos e 11 meses [recebendo bolsa aluguel], ia completar 4 em outubro. A gente recebe um pouco de crítica na rua, porque pra eles a gente pegou o lugar deles...

No entanto, a mudança para o apartamento não implica simplesmente na alteração de endereço para Lucilene, visto que alude principalmente sua "mudança de padrão", comparando sua condição anterior, descrita como "uma pequena moradia onde todos dormiam imprensados" para um apartamento de 3 dormitórios:

\begin{abstract}
Se eu não tivesse saído de lá, com o padrão de vida que eu to tendo agora, eu não tenho o que reclamar. De uma casa de dois cômodos que eu dividia com guardaroupa e uma cozinha que parecia um quadrado. (...) Daí, tá vendo, de uma casa pequenininha, que dormia todo mundo imprensado, eu achei na minha mente porque eu não tinha visto isso aqui ainda - que era só dois quartos. Quando eu cheguei aqui, são três quartos! Tanto que quando chega aqui, todo mundo acha muito bonito esses apartamentos... Quem me vê assim sorridente, brincando, com essa aparência, com o cabelo assim melhor, o apartamento assim, meus filhos comendo, tendo até pão sobrando ali. Eu chego até a ajudar outras pessoas com necessidade. Muitas famílias por aí queria estar no padrão de vida que a gente tá. A gente pode se sentir assim uma pessoa de classe "um pouco" média. Já pensou? Tenho um apartamento no meu nome, água e luz no meu nome. Se eu chego numa concessionária de carro, se eu chego num banco, nesses alto padrão assim, pra pegar um empréstimo. Olha só o nível de padrão que a gente chegou. O nome da gente tá lá em cima. A prefeitura fez a gente subir.
\end{abstract}

O fato de ter um imóvel no seu nome também é valorizado pela ex-moradora do Lago Azul, em razão de que antes era um "terreno irregular em mananciais, terreno que não tem escritura, é contrato de compra e venda entre os vizinhos mesmo. É uma terra que a gente não sabe nem de quem era. Dizem que era do Bradesco na época. Tinha aquelas torres da Eletropaulo, então a gente ficou sem saber se era da Eletropaulo, do Bradesco e assim foi passando os anos".

Segundo Lucilene, os moradores tiveram isenção de seis meses para o início da cobrança das prestações do apartamento. A assistência social recomendara que a economia de recursos deveria ser aplicada nos acabamentos e na compra dos móveis, uma vez que os apartamentos foram entregues somente com revestimento de piso e azulejo na cozinha, sanitário e área de serviço. Lucilene pintou o apartamento de verde, combinando elementos do piso com a cor das paredes e com o tecido de capa do sofá; decoração esta que ela exibe com orgulho. 

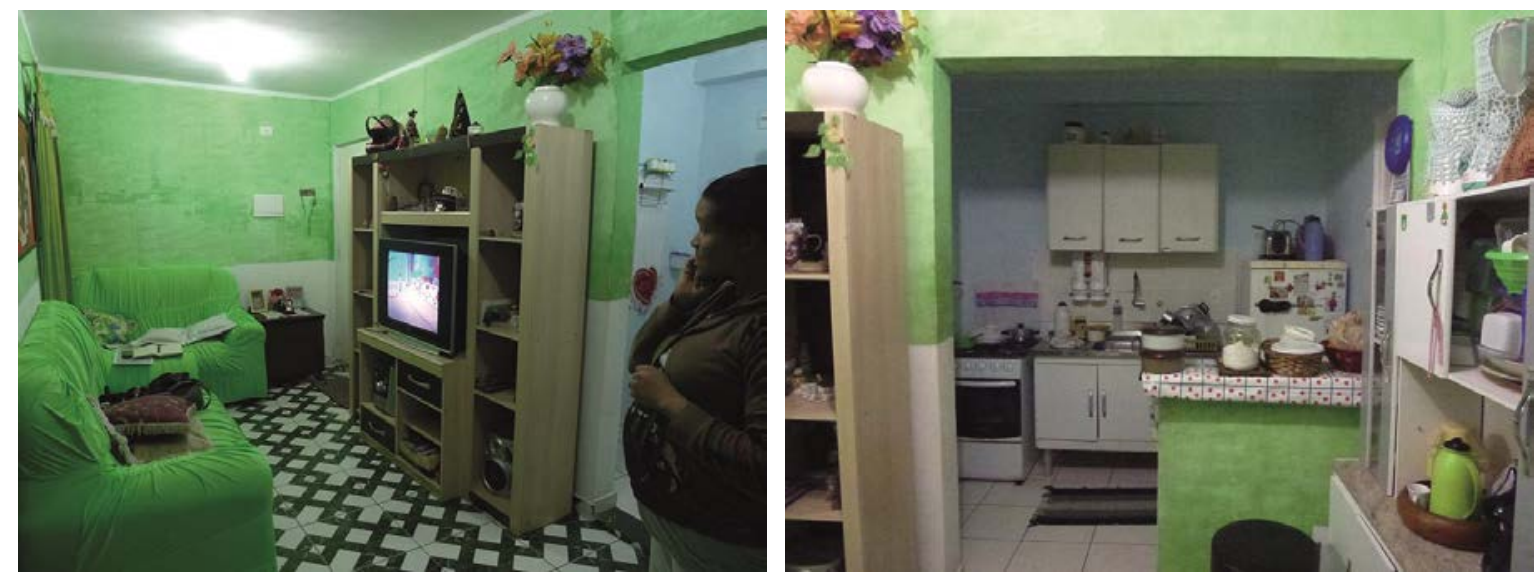

Figura 56 - Apartamento de Lucilene mobiliado e decorado. Crédito: Melissa Matsunaga, 2014.

A prestação do apartamento de Lucilene é de $\mathrm{R} \$ 111,00$. Além disso, há gastos com o condomínio de $\mathrm{R} \$ 50,00$. Sua conta de luz é $\mathrm{R} \$ 25,00$ e a de água $\mathrm{R} \$ 7,00$, ambas cadastradas como tarifa social. Lucilene recebe bolsa-família no valor de $\mathrm{R} \$ 150,00$.

Contudo, apesar da moradora exprimir satisfação em relação ao apartamento, a localização do Conjunto Residencial na fronteira com Diadema impõe empecilhos em relação às creches e escolas na região. A falta de vagas em São Paulo coloca a necessidade de forjar um endereço de Diadema para conseguir vagas no outro município. Sua filha Lidiane está fora da escola, tendo estudado até a $7^{\text {a }}$ série do Ensino Fundamental.

A organização e gestão do condomínio estão sendo acompanhadas pela assistência social da prefeitura uma vez por semana. O que não exclui o encaminhamento da gestão pelos próprios moradores:

Quando a gente chegou aqui tinha porteiro da prefeitura. Só que a prefeitura falou, vou levar os porteiros embora e agora é com vocês. A portaria ali ficou sem porteiro nenhum. Se não fosse um morador, que a gente chama ele de Baixinho, que ele mora lá no [condomínio] C. Ele que começou a tomar conta da portaria ali pra gente. Porque se ele não começasse a tomar conta da portaria, com um pedaço de pau assim à noite, não sei quantos meses ele ficou cuidando da gente aqui, ia entrar qualquer um. Aí depois os moradores foram se ajeitando e hoje eles [os moradores] mesmo que pagam pra gente trabalhar na portaria.

Hoje, Lucilene trabalha na portaria do Condomínio 2, revezando a escala de trabalho de 12h com outros três funcionários também moradores. Além disso, também acumula a função de representante do Bloco B junto ao Conselho do Condomínio 2, o que lhe confere experiência e conhecimento sobre seu funcionamento, procedimentos e regras.

Infelizmente, nem todos os moradores pagam a taxa do condomínio, fato que ela reclama, sendo essa a fonte do recurso que paga os salários dos funcionários. Com a inadimplência, ocorrem atrasos dos pagamentos, ademais, esses valores poderiam reverter para o próprio condomínio: "se 
todo mundo pagasse direitinho, nós já teríamos camisetas, uniformes, crachás, computador com máquina de foto e tudo". Antes de assumir a portaria do condomínio, Lucilene trabalhou num lavarápido e sempre fazia bicos de diarista.
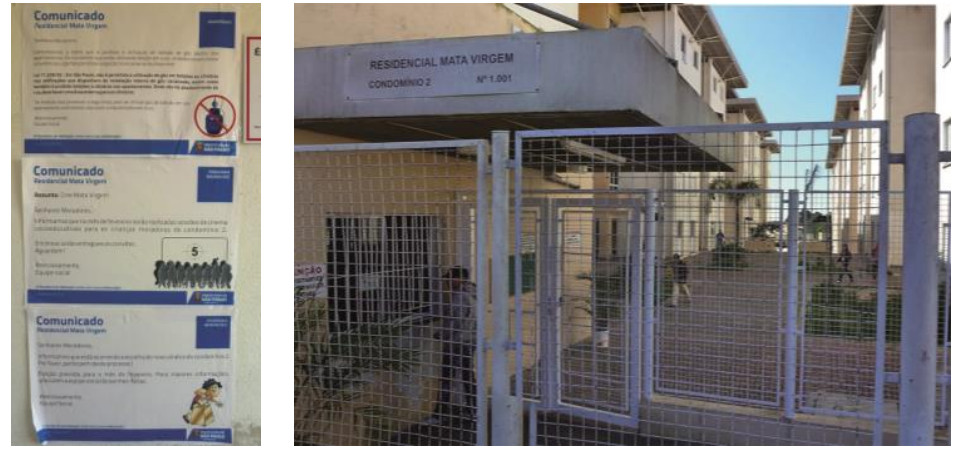

Figura $57 \quad$ - Figura 58 - Portaria do condomínio, local de trabalho de Comunicados da Lucilene. Crédito: Melissa Matsunaga, 2014. SEHAB aO

condomínio. Crédito:

Melissa Matsunaga, 2014

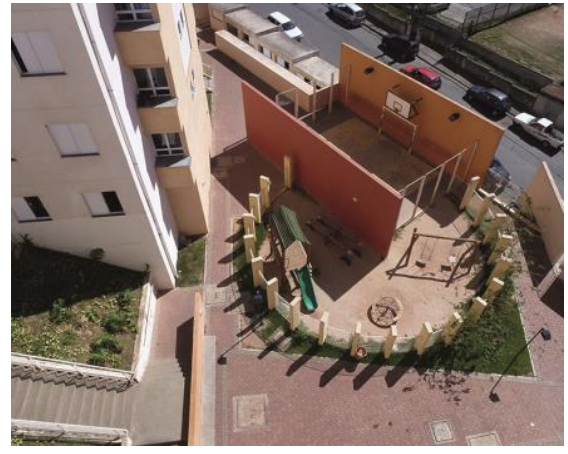

Figura 59 - Área de lazer e recreação do condomínio. Crédito: Melissa Matsunaga, 2014.

Segundo Lucilene, várias pessoas "já venderam e foram embora”, de maneira irregular perante os procedimentos da Prefeitura. E devido aos problemas que são gerados com essa imposição de permanência, Lucilene com a experiência de ser representante do bloco e lidar diariamente com o conflito, sugere:

Eles deveriam trabalhar pelo fato do seguinte: não estamos com problema de condomínio? Sabe por que que tá esse problema de condomínio? São as pessoas que não querem viver aqui dentro, não querem cuidar, não sabem o que é pagar um condomínio, não sabe o que é ter uma portaria que recebe tudo do correio aos alimentos, às visitas... Então a prefeitura deveria chamar essas pessoas. O condomínio não existe problema, o problema quem faz é o morador. A prefeitura deveria chegar e fazer o seguinte: já que vocês não querem ficar aqui, vocês vão assinar um termo de responsabilidade, vocês vão vender pra uma família que quer morar no seu padrão, paga uma taxa de devolução, que vocês estão devolvendo pra prefeitura pra gente poder fazer outra documentação pra essa nova família que quer morar no condomínio e querem cuidar do patrimônio e aí vocês compram a casa que vocês quiserem. Pronto! Acabou o problema!

Ela tem a expectativa de voltar a morar em casa ao invés de apartamento, pois tem a esperança de que a prefeitura permita vender o apartamento um dia:

Todos os dias eu falo pra Deus preparar uma casa que eu sempre quis e um bom comprador, naquele padrão, mas dentro da lei. A casa que eu falo é assim: uma casa com três dormitórios, uma garagem, que eu sempre quis ter uma casa com garagem. Cheguei até a sonhar com essa casa já, pintada de cor de laranja ainda.

Durante esse tempo, a filha mais velha, Daiane, acabou engravidando e mesmo já morando com o filho no apartamento resolveu voltar a morar no Residencial dos Lagos junto com o marido e 
o bebê. Além da filha, a mãe de Lucilene também mora no Lago Azul, permanecendo com laços afetivos e familiares com o antigo bairro: "Tô tentando me adaptar, mas pra falar a verdade ainda continuo com o Lago Azul dentro de mim. É que eu tenho uma história de vida lá né...”.

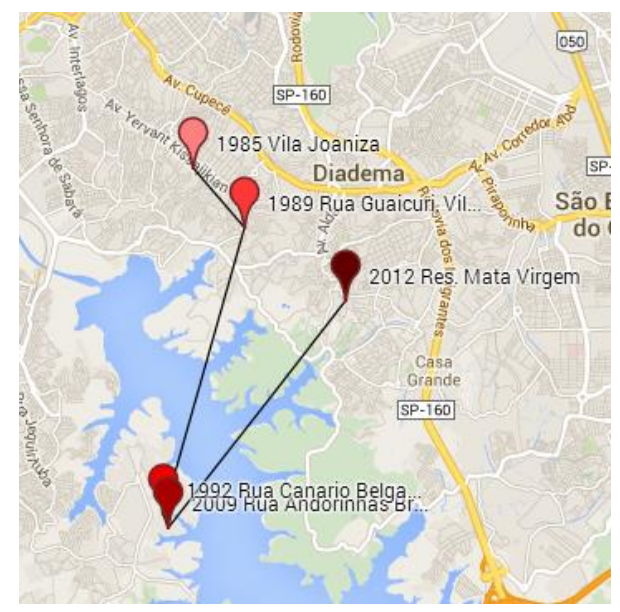

Figura 60 - Locais de moradia de Lucilene. 


\subsection{MANDE NOTÍCIAS DA MARGEM DE LÁ}

O conjunto de moradores aqui apresentado e suas experiências, sem dúvida, não esgotam as diversas possibilidades de situações dos moradores submetidos ao processo de remoção, mas exemplificam algumas delas. Assim, num contexto de vulnerabilidade social, econômica e física, percebem-se as estratégias que os vivenciadores encontram, numa atitude de enfrentamento para superar essa mesma condição. Nesse caminho, a precariedade urbana promove um horizonte imediatista na busca de solução de necessidades concretas: Débora, com suas três filhas em busca de conquistar o direito para entrar na fila de um apartamento; Seo Pedro, diante da ameaça anunciada de sua remoção, parte em busca de outra cidade onde seus filhos possam crescer com dignidade; Lucia e Lucilene almejando próximas oportunidades configuradas pelos programas e ações em curso.

Convém destacar que as histórias de vida tratadas neste capítulo da dissertação dizem respeito a casos em que houve consentimento e anuência para o relato. $\mathrm{O}$ aspecto da entrevista de Eunice e Carlos - em que optei em adotar nomes fictícios exatamente pelo conteúdo e modo de consecução da conversa, apesar da autorização para uso do material e imagem - com desconfiança e poucas palavras sugere a expressão de um sentimento de ordem coletiva não apenas por famílias removidas, ou, se na condição de removidas, não apenas sobre a interferência de uma ação externa em suas trajetórias, que poderia facilmente demonstrar insatisfações e revoltas, mas por outro lado, sobre a invasão da privacidade de suas vidas e suas histórias, aflorando constrangimentos ou particularidades de suas intimidades que não eram de seu interesse externar numa entrevista a uma desconhecida.

Nota-se, a partir dos casos, que a mobilidade se configura como uma característica da vida para essa parcela da população, ou seja, não há uma expectativa de estabilidade ao longo do tempo no território. Os sentimentos em relação ao lugar em que se vive perdem força frente às necessidades e oportunidades em busca de melhorar a condição de vida. Colocam-se em questão os agenciamentos e recursos mobilizados pelos mesmos frente a um processo que ao destituí-los do seu território, possibilitam a abertura de uma atitude inventiva, sem passividade, numa resposta adaptativa ao contexto em que se encontram. 



\section{À GUISA de CONCLUSÃo}

As histórias partilhadas nesta dissertação resultam do enfoque da pesquisa de campo, que buscou acentuar as especificidades em relação à transformação da paisagem que se configura cotidianamente. Desde a formação dos bairros até as situações atuais de vida, as experiências relatadas demonstram retratos de quem vive a realidade da periferia paulistana localizada em área de mananciais. A pesquisa de campo, marcada não só pela possibilidade de configuração em rede onde um depoente indica outros possíveis depoentes, mas também, pela vivência e acompanhamento no período de janeiro de 2013 a outubro de 2014, ressaltou a importância do método que partia exatamente do pressuposto de processo contínuo. Ao mesmo tempo em que cada depoimento apresentou sua especificidade, suas análises conjugadas com discussões acadêmicas e problematizações sociais sobre os conteúdos evocados, estes me conduziram ao estabelecimento de um fio narrativo. Desse modo, conjugando as representações mobilizadas, busquei compreender o processo de produção social que origina os bairros estudados e localizá-los na matriz discursiva que os problematiza atualmente, com o cuidado de não reiterar dualidades e, sim, apontar diversas nuances acerca da questão ou tema enunciado.

Partindo das representações dos vivenciadores sobre a transformação de sua paisagem, percebi que o histórico de constituição de cada um dos bairros continha elementos fundantes nas representações evocadas nas entrevistas. Ao resgatar esses momentos de formação dos bairros, cruzando as lembranças coletivas principalmente dos moradores antigos que presenciaram suas constituições e informações constantes no processo judicial da ACP (glebas, proprietários, relatórios técnicos de fiscalização das áreas), suas origens - ainda que ambos remetessem à clandestinidade do parcelamento do solo -, remetiam a processos heterogêneos. O Cantinho do Céu passou por um processo distinto de adensamento populacional do que fora constatado no Lago Azul, e essa origem diferenciada sugeria pistas das origens da discriminação enunciada por seus vivenciadores, principalmente do Lago Azul em relação aos outros: “aqui é condomínio, nós pagamos e lá é invasão, eles invadiram”.

Para efeito organizativo das análises, defini três momentos que diziam respeito aos acontecimentos históricos relacionados aos conteúdos evocados, e nessa operação analítica, percebi que a dimensão do vivido e experimentado nesse passado fundante dos bairros e as relações de convivência que se estabeleceram desde então (as lideranças não unificavam as pautas entre si, 
atuavam isoladamente) contribuíram para acirrar os processos em disputa através da reiteração de que "aqui e lá" são diferentes. E essa diferenciação é a que se preserva no presente.

Assim, para cada bairro, busquei reconstituir os principais momentos: o Cantinho do Céu apresentava moradores "originais" na condição de chacareiros, que habitavam o local e que reivindicavam para si a condição privilegiada e elitizada do território. Os conflitos iniciais remetiam a disputas relativas ao direito de propriedade em confronto ao direito à moradia, sendo que o que estava em jogo era a perda do isolamento e, com isso, o convívio com o "povão" ameaçava essa opção de vida que os chacareiros haviam elegido para si. A violência inicial, com a presença de matadores que tomavam as casas, expulsando recém-chegados - narrado tanto por chacareiros e moradores do Cantinho e do Lago Azul - além da "negligência" e desresponsabilização dos proprietários J.M. Brito e Irmãos Maretto - este último com (encen)ação de reintegração de posse perante o juiz - corroboram no engendramento do estigma de "invasores" pelos chacareiros e pelo Lago Azul (cujo processo de formação é de alguns anos antes ao Cantinho).

Dito de outro modo, as brigas na Justiça entre proprietários do Cantinho do Céu e novos moradores (no caso a ação de reintegração de posse em 1991 e a execução da medida liminar em 1998), associadas às mobilizações populares que se concretizaram nesse período, marcaram de modo pejorativo o histórico do Cantinho do Céu. O fato de haver um conflito judiciário dessa magnitude no bairro, que envolvia criminalmente os moradores, foi utilizado como elemento de diferenciação pelos moradores do Lago Azul, que na sua origem diferenciada, através do suposto condomínio, não passou pelo mesmo histórico conflitivo. O conflito judiciário no Lago Azul recaiu sobre os loteadores e suas imobiliárias - salvaguardando os moradores - e fortalecendo, com isso, um processo de formação identitária, que é expresso na autodenominação das ruas e da toponímia que unifica as três glebas, passando a se autodesignar como Parque Residencial dos Lagos.

As práticas políticas incidentes no território analisado também são atravessadas pela pesquisa, apontando o caráter imediatista e clientelista nas ações descritas. Desse modo, a convivência cotidiana nos bairros e os efeitos de tais práticas se colocaram no trabalho como elo dos sentimentos e discursos mobilizados no seu enfrentamento. No momento de constituição dos bairros, o papel das lideranças se apresenta como fundamental, pois não apenas assegurou a permanência dos moradores em momentos de ação de despejo, como também conseguiu benfeitorias para os bairros. Hoje, tendo em vista a consolidação e as obras em curso, a atuação das lideranças começa a ser questionada. Ao mesmo tempo, novos atores entram em cena, com a emergência da produção cultural periférica através de agremiações e articulação em rede para 
consecução das suas intervenções culturais. Notadamente, os coletivos atuam de modo regional através de projetos específicos, articulando-se e reorganizando-se continuamente. Os participantes referem-se a si mesmo como agentes, que agem de modo articulado a outros agentes e outros coletivos, numa configuração em rede. Ainda que o caráter seja de promoção de intervenções artísticas e culturais, o modo de produção da cidade pauta as ações dos coletivos, que intervém na realidade contraditória produzida na metrópole paulista, buscando transformar o que era estigma em orgulho, através da ressignificação de atitudes, comportamentos e espaços.

$\mathrm{O}$ fato do processo judicial da ACP ainda estar em trâmite, também levanta alguns aspectos que merecem atenção. A atitude do Promotor Amin, autor da ACP, pode ser considerada de caráter inovador, já que é uma das primeiras ações civis onde os réus correspondem aos representantes do poder executivo, incluindo os administradores regionais da gestão Erundina, Leonide Tatto e da gestão Maluf, Enoque Leocádio, a quem caberia a função de fiscalizar a ocupação do solo e não "facilitá-lo" de modo irregular apoiado em denúncias anônimas e relatos de moradores. A longa negociação para resolução dos conflitos, auferindo a necessidade de elaboração de estudos ou atribuindo a competência para outro órgão ou setor envolvido, indica que somente a partir de uma "vontade política" a solução dos problemas começou a ser encaminhada. A minuta do Termo de Ajustamento de Conduta (TAC) surge apenas no volume 21 do processo, após 17 anos de instauração da ACP. Pela minuta em discussão (até setembro de 2014) o horizonte de finalização para o processo completo de regularização fundiária do Complexo para o ano de 2022 ainda promete, por sua vez, outro longo período de negociação.

Não obstante a intervenção urbana em curso, as remoções e suas implicações foram outro ponto destacado no trabalho, sendo necessário resgatar novamente a matriz discursiva da ação de urbanização frente às ações de desfavelamentos recorrentes (até hoje) de modo geral no país. No âmbito local, entretanto, os depoimentos mostram que diante dos investimentos públicos anunciados, a possibilidade de remoção se configurou como uma imposição de mudança, onde alguns a consideram como uma oportunidade de melhorar de condição, enquanto outros veem seus planos e sonhos serem adiados. Dependendo da condição física da moradia e das relações sociais pré-existentes, cada um dos vivenciadores entrevistados sofre as angústias e dúvidas pela possibilidade de sofrerem tal intervenção em suas vidas. A narrativa de Seo Pedro e Cleonice é um exemplo de como o anúncio da remoção causou impacto direto nos seus planos de vida e da família, e como a demora na execução também promoveu um horizonte de incertezas e inseguranças sobre o que o Estado pretendia realizar. Além disso, a imposição do deslocamento faz 
com que os laços afetivos em relação ao bairro sejam desconsiderados quando a única opção é sair, como mostra a narrativa de Lucilene, que pondera sobre sua condição social, que mudou porque agora ela tem um apartamento em seu nome, lhe conferindo uma posição social que nunca teve, mas, ao mesmo tempo, sonha em morar numa casa e que sente saudades do antigo bairro, pois além de ser onde moram sua mãe e sua filha mais velha já casada, é o lugar com o qual ela diz ter uma "história".

A característica de proximidade da represa e o que ela representa ambientalmente, no entanto, é aspecto pouco evidente nos diversos depoimentos. Com exceção do pescador do Cantinho do Céu, Seo João, que faz uso dela diariamente, conferindo-lhe amplo conhecimento sobre sua degradação ambiental e como ela se dá.

Por fim, retomo a discussão inicial da dissertação. Cabe destacar que o dilema habitação x meio ambiente expressa de modo dual ocultando elementos importantes na questão vinculada de maneira territorial ao que se denominou "área de mananciais". Recuperando a argumentação expressa pelas políticas em curso de que o objetivo é de preservar os mananciais, resultado de uma construção histórica, as análises e estudos, além de ações públicas, devem recair não apenas ao território denominado como área de mananciais, mas da bacia hidrográfica do Alto Tietê em sua total abrangência, relacionando a universalização do tratamento de esgoto da RMSP e o funcionamento da represa Billings. Sem dúvida, os assentamentos sem infraestrutura de saneamento localizados em área de mananciais contribuem para a poluição das águas. Mas, pelo funcionamento da represa, que altera consideravelmente o mecanismo natural de drenagem superficial pelos diversos usos sobrepostos, esse território denominado "área de proteção e recuperação dos mananciais" e o conflito que as moradias irregulares causariam diretamente aos mananciais, devem ser estudados com atenção. Ao se instituir um território denominado "área de proteção aos mananciais", cujo perímetro foi delimitado de acordo com a bacia hidrográfica, já que os usos incidentes nessa bacia implicariam na qualidade ou na poluição das águas da represa, o debate fica restrito a esse mesmo território, ou seja, regionaliza a questão apenas para a área de proteção aos mananciais, promovendo uma segregação simbólica e por que não, ideológica. Os dados coletados informam que a maior parte dos assentamentos precários - e que originariam tal poluição pela condição de serem caracterizados como assentamentos sem infraestrutura - estão localizados fora da área de mananciais. Porém, o dado mais importante é que do total dos efluentes coletados da RMSP, que correspondem a $88 \%$, apenas $54 \%$ é tratado, ou seja, a poluição é feita pela ineficiência do sistema de saneamento, sendo essa grande carga de efluentes da RMSP (advindas de 
assentamentos precários irregulares e também de assentamentos regulares), despejados nos Rios Tamanduateí, Tietê e Pinheiros, lançados no lago da Billings pela reversão do canal Pinheiros.

Em outras palavras, a maior parte da origem da poluição da represa advinda dos efluentes domésticos jogados nos corpos hídricos não se localiza em área de mananciais e, tampouco, deve ser discriminada apenas pelos assentamentos precários. A constatação aqui colocada, sem dúvida, não é nova e não desconsidera o debate e a política pública que engendrou tal construção teórica, apenas aponta que a elaboração do discurso do meio ambiente (que é associado ao saneamento) deve ser tratado com cautela nessa problematização territorial, visto que gera representações sociais de quem mora na área de mananciais, sendo este responsável pela poluição da represa. Desse modo, o que se constitui como questão propriamente a ser enfrentada para esse território denominado área de mananciais, é a infinidade de casos de assentamentos irregulares que a LPM instituiu e que a LPRM busca, ou deveria buscar solucionar. E é desse modo que o histórico conflitivo da região é estabelecido de maneira a apresentar um dilema sem solução, com disputas setoriais, interesses políticos e negociações que recorrem à lei, adiando o quanto possível seu enfrentamento.

E nesse sentido, a cidade continua se (re)produzindo de modo conflitivo frente ao novo contexto da lei de mananciais, cujo território continua em disputa: permanecem as ocorrências de ocupações de glebas vazias. Após as manifestações de junho de 2013, várias glebas vazias foram ocupadas pelo movimento de moradia. Em que pese a discussão sobre a preservação dos recursos hídricos e políticas públicas habitacionais, por um lado, notam-se as mesmas práticas recorrentes desde os anos 1980, onde a pauta da moradia se isola, conflitando com as funções ambientais que essas áreas desocupadas desempenham no próprio abastecimento da metrópole. Por outro lado, as ocupações em recorrência evidenciam que o acesso à terra continua uma questão premente na metrópole paulistana.

\section{NOtA Final}

Seis meses atrás, quando estava iniciando o fechamento da pesquisa, começando a escrever de fato esta dissertação, sofri uma angústia paralisante, típica de mestrandos na proximidade do prazo final. Passava dias, semanas refazendo a estrutura dos capítulos, tentando encadear de um modo lógico tudo aquilo que pesquisei. Era muito difícil passar para o papel as vivências partilhadas dos últimos anos. Talvez estivesse implícito - e só agora percebo - que escrever encerraria definitivamente uma etapa da minha vida. Não só por finalizar o mestrado - o que é uma grande conquista - mas por finalizar um ciclo que começou quando eu me mudei para São 
Paulo, no início de 2009, e me envolvi com o projeto de urbanização do Cantinho no âmbito do escritório de Marcos Boldarini.

Quando visitei a primeira vez o Cantinho do Céu - que fui descobrir mais tarde que era o Lago Azul - não sabia ainda qual a proporção que aquela região, aquele projeto e aquelas pessoas tomariam na minha vida. Ver a criançada brincando na água poluída da represa era no mínimo chocante para uma jovem arquiteta cheia de pretensões: "Ninguém disse a eles que essa água está contaminada? Que é perigoso e que podem ficar doentes?"

Ao longo do processo projetual do parque linear, que durou aproximadamente três anos (2009 a 2011), mesmo com muitas vistorias de campo, existia uma lacuna que nunca foi preenchida e talvez tenha sido essa ausência que tenha me inquietado a ponto de querer ingressar no mestrado. Eu precisava conhecer as pessoas que moravam ali. Nessa perspectiva, estudar a transformação da paisagem no Cantinho (algo que eu mesma defini) me parecia um luxo, uma atividade sem sentido, como se eu estivesse desperdiçando uma grande oportunidade de investigação acerca da implementação da política pública.

Como já dito, o trabalho de campo e o envolvimento com os vivenciadores me levaram a buscar em outras áreas do conhecimento a essência do que eu tinha o intuito de pesquisar. Eu buscava uma fórmula, uma receita; eu lia o roteiro de paisagem do Euler ${ }^{76} \mathrm{e}$ apesar de parecer um procedimento simples a ser adotado, era de uma profundidade que me escapava. Quando me deparei com os textos ${ }^{77}$ de Carlos Nelson Ferreira dos Santos senti um enorme alívio: era como se alguém já tivesse passado por isso e sua experiência poderia me dar pistas de como caminhar por essas novas "paisagens". Ledo engano, o próprio Carlos Nelson já exporia que outros pesquisadores chegavam a resultados distintos ao seu, ou seja, essa trajetória sempre será única.

Acredito que minha pesquisa abra muitas outras possibilidades de investigação, seja no âmbito das políticas públicas, avaliando de fato a política habitacional empreendida, seja no âmbito do projeto de urbanismo e de paisagismo, analisando seus elementos, seu desenho, seu resultado. Era de se esperar que o meu trabalho dissesse respeito a algum desses temas centrais da Faculdade de Arquitetura e Urbanismo da Universidade de São Paulo. No entanto, ao ingressar na área de

\footnotetext{
76 SANDEVILLE JR., Euler. Paisagens e Métodos. Algumas considerações para a elaboração de roteiros de estudo na paisagem intraurbana, 2004.
}

77 SANTOS, Carlos Nelson Ferreira dos. Como e quando pode um arquiteto virar antropólogo? In.: VELHO, Gilberto (org). Desafio da Cidade. Rio de Janeiro, Editora Campus, 1980, p-37-57. E SANTOS, C. N. F.; VOGEL, A. (Coord.) Quando a rua vira casa - A apropriação de espaços de uso coletivo em um centro de bairro. 2. ed. rev. e atualizada. Rio de Janeiro: FINEP/IBAM, 1981. 
concentração Paisagem e Ambiente, e mais precisamente no NEP, as pretensões da jovem pesquisadora foram desconstruídas a tal ponto que não fazia sentido fazer uma verificação do projeto e a ação do Estado, ou sobre o que deu certo, o que deu errado. As contradições e ambiguidades da "antropoteta ${ }^{78}$ ", nos termos de Carlos Nelson, eram mais prementes. Ao longo da pesquisa percebi que não era suficiente "estar em campo", recomendação que Euler sempre reiterava, e que ao fim pude entender. Era necessário saber onde eu, Melissa, estava naquela paisagem.

O campo foi a parte mais interessante da pesquisa, sem dúvida, enquanto a elaboração do texto, era outro desafio que precisava enfrentar. Logo percebi que era preciso me deixar afetar pelo próprio texto a ponto de defini-lo como narrativa. As conversas e entrevistas que realizei mereciam uma atenção especial já que muitos dos vivenciadores partilharam comigo suas histórias, seus sofrimentos, suas dúvidas, suas alegrias, suas conquistas e confiavam em mim o não-distorcimento de seus depoimentos.

Ao fim do processo de escrita, tive contato com a publicação "O Gosto do Mundo Exercícios de Paisagem", de Jean-Marc Besse, filósofo francês estudioso da paisagem. E ao lê-lo, os sentidos pareceram se completar. Já no primeiro artigo, o autor coloca o paisagista como "portador do inacabamento". Atitude esta, nem sempre considerada em projetos. Os arquitetos ainda acreditam que são designados para solucionar problemas, muitas vezes numa postura não dialógica, como se o desenho ou o projeto estivesse acima de qualquer demanda mais concreta, às vezes sem nem visitar o lugar para o qual está projetando e, ao mesmo tempo, acreditando que o projeto irá melhorar a vida das pessoas. Nessa procura por quem seria o antagonista da minha narrativa, descobri que era eu mesma esse personagem. E tendo isso em vista, o trabalho expressa contradições emergentes desse caminho. Se era necessário recomeçar adotando como metodologia a perspectiva dos depoentes, a cautela diante de tal desafio se colocou como uma barreira a ser enfrentada, que exigiu o deslocamento de procedimentos discursivos recorrentes (não apenas no campo dos estudos acadêmicos, mas também, na operação das políticas públicas), e o reposicionamento contínuo da pesquisa nessa perspectiva de renovação constante.

\footnotetext{
${ }^{78}$ Carlos Nelson se autodenomina um antropoteto, que seria a fusão entre 0 antropólogo e 0 arquiteto, já que ele mesmo dizia atuar nos projetos de urbanização de favelas a partir de uma postura de "participação observante". Quando ingressa no Programa de Pósgraduação em Antropologia Social do Museu Nacional da UFRJ, ele, que já se via como um antropólogo ad hoc, inverte e conjuga as abordagens estabelecidas de pesquisa no âmbito da antropologia e da arquitetura. $O$ provocador antropoteto, ciente dos riscos de tal procedimento, deixa claro que gostava de ter "as vantagens e as desvantagens da ambiguidade", afinal "vivemos todos em um mundo que só não deixa confusos e perplexos uns tantos que pensam que sabem tudo e que podem reduzi-lo à pureza de uma forma simples, universal e científica (não seria mais correto chama-la alquímica?)". (SANTOS, 1981:12-14)
} 
Por fim, trago um dos momentos de angústia e diria até, melancolia da minha inserção no campo, provocando de modo ingênuo o conceito de paisagem a partir de uma perspectiva visual ou, no extremo, da sua impossibilidade. Assim, reafirmo a paisagem como ente relacional e, por isso, a existência de inúmeros Cantinhos, e não apenas um Cantinho do Céu.

\section{A JANELA de FÁtima}

Fátima tem 38 anos, é moradora do Lago Azul desde os 14 anos, tem quatro filhos e é separada do marido. Dois filhos moram com ela à Rua Falcão Negro, Tamires de 18 anos e Lucas de 6 anos. Uma das filhas mais velhas, que já é casada, mora na casa dos fundos do mesmo lote. Fátima é diarista e trabalhou como auxiliar de limpeza anteriormente.

Meu contato com ela se deu no dia 31 de maio de 2013, quando conversava com Dona Vera no parque. Ela nos abordou e questionou à liderança do bairro sobre o status do "seu caso": sua casa teve a estrutura abalada devido ao processo de remoção da construção vizinha. A casa de Fátima seria a última a ser consolidada na rua, ou seja, a partir da casa dela (em direção à represa) todas as outras estavam sendo removidas. E desde que sua moradia foi atingida, a demolição da construção vizinha foi suspensa, não sendo finalizada. Fátima aguardava uma solução por parte da construtora responsável pelas obras, ela queria saber se seria indenizada.

Fiquei curiosa em ver a situação da moradia, que pelo relato estava na iminência de desmoronar. Ao entrar em sua casa, cujo acesso é pelos fundos de uma edificação subdividida para duas famílias (o ex-marido mora com o pai na casa da frente) um dos aspectos que mais me chamou a atenção foi o fato de sua janela estar bloqueada pela construção ao lado. A ventilação era feita por uma fresta com o vizinho e a cobertura permitia a entrada de luz por um mecanismo de iluminação zenital. Quando a indaguei sobre sua janela bloqueada, ela respondeu que não podia fazer nada, já que o lote ao lado pertencia ao vizinho e ele poderia construir do jeito que ele quisesse. As rachaduras existentes (inutilmente preenchidas com massa corrida) nos encontros de parede eram evidências de um recalque do solo, mas somente um engenheiro experiente poderia dar o laudo de uma condenação estrutural em curso. Aquela janela sem abrir para nada, nenhum horizonte, se apresentou para mim como símbolo de uma triste violação de direitos. $\mathrm{O}$ risco de desmoronamento da casa era símbolo, sem dúvida, da vulnerabilidade física, social e econômica que Fátima estava inserida. E esta configuração representava também que a janela não colocava nenhuma perspectiva, e quem (não) olhava por ela, resignava-se em sua condição. Apesar de sua 
reivindicação, através da liderança para solução de seu caso, essa mesma atitude significava um “aguardar” que alguém resolvesse sua situação.

Em ligação telefônica em 25 de outubro de 2013, quase cinco meses após o primeiro contato, Tamires, a filha mais velha que mora com Fátima, informou que tudo continuava igual, ou seja, continuavam morando na mesma casa, com as mesmas rachaduras, agora estagnadas. Havia uma novidade: a construção vizinha, que não fora totalmente demolida, estava sendo reformada por um outro morador do bairro, cujas marteladas de reconstrução substituíram as outrora de demolição.

Achei importante inserir o caso de Fátima que, apesar do tom melancólico, foi muito revelador sobre o que seria estudar a paisagem. Essa condição de isolamento era instigante, pois não me dava aberturas para discutir a paisagem a partir do lance de vista, do enquadramento, da perspectiva visual. Se era necessário entender a paisagem para além do que se vê, como me posicionar diante de tal situação? A janela era uma cilada, foi necessário olhar além da janela para entender seus bloqueios e seus significados em reserva, atividade que me propus neste trabalho.

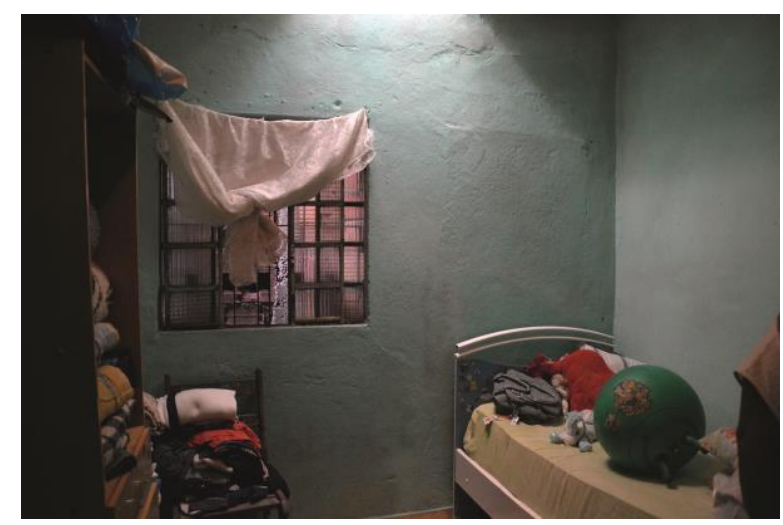

Figura 61 - Quarto da residência de Fátima. Crédito: Melissa Matsunaga, 2013. 



\section{REFERÊNCIAS BIBLIOGRÁFICAS}

ALBERTI, V. Manual de História Oral. 2 ed. rev. atual. Rio de Janeiro: Editora FGV, 2004.

ALBUQUERQUE, M. J. de. Verticalização de favelas em São Paulo: balanço de uma experiência (1989 a 2004). 2006. Tese (Doutorado em Estruturas Ambientais Urbanas) - Faculdade de Arquitetura e Urbanismo, Universidade de São Paulo, São Paulo, 2006.

ANCONA, A. L. Direito ambiental, direito de quem? Políticas públicas do meio ambiente na metrópole paulista. 2002. Tese (Doutorado em Arquitetura e Urbanismo) - Faculdade de Arquitetura e Urbanismo, Universidade de São Paulo, São Paulo, 2002.

ANGILELI, C. M. M. M. Paisagem revelada no cotidiano da periferia: Distrito de Brasilândia, Zona Norte do Município de São Paulo. 2007. Dissertação (Mestrado em Paisagem e Ambiente) - Faculdade de Arquitetura e Urbanismo, Universidade de São Paulo, São Paulo, 2007.

Chão. 2012. Tese (Doutorado em Paisagem e Ambiente) - Faculdade de Arquitetura e Urbanismo, Universidade de São Paulo, São Paulo, 2012.

ALVIM, A. B. Direito à cidade e ao ambiente na metrópole contemporânea. O projeto "Cantinho do Céu" na represa Billings, São Paulo. Arquitextos, São Paulo, ano 12, n. 135.03, Vitruvius, jul. 2011 $<$ http://www.vitruvius.com.br/revistas/read/arquitextos/12.135/4015>. Acesso em 17 set 2014.

BARBAN, V. (Org.). Fortalecimento da sociedade civil em regiões de extrema pobreza. São Paulo: Instituto Pólis, 2003.

BARDA, M.; FRANÇA, E. (Org.). Entre o céu e a água: o Cantinho do Céu. São Paulo: HABI Superintendência de Habitação Popular, 2012.

BAUER, M. W.; GASKELL, G. Pesquisa qualitativa com texto, imagem e som - Um manual prático. 10. ed. Petrópolis: Editora Vozes, 2012.

BERQUE, A. (Dir.). Cinq Propositions pour une Théorie du Paysage. Seyssel: Champ Vallon, 1994.

BESSE, J.M. O gosto do mundo - exercícios de paisagem. Tradução Annie Cambe. Rio de Janeiro: Editora UERJ, 2014.

BOGUS, L. M. M.; PASTernAK, S. Como anda São Paulo - Volume 3. Rio de Janeiro: Letra Capital. Observatório das Metrópoles, 2009.

BONDUKI, N. Origens da habitação social no Brasil: arquitetura moderna, lei do inquilinato e difusão da casa própria. São Paulo: Estação Liberdade, 1998.

BOSI, E. Memória e sociedade, lembranças de velhos. 2. ed. São Paulo: Companhia das Letras, 1994.

Tempo vivo da memória - Ensaios de Psicologia Social. 2. ed. São Paulo, SP: Ateliê Editorial, 2003.

BRASIL. Ministério das Cidades, Secretaria Nacional de Habitação. Guia para o Mapeamento e Caracterização de Assentamentos Precários. Brasília, MCidades, 2010.

CABANES, R.; GEORGES, I.; RIZEK, C.; TELLES, V. (Orgs.). Saídas de emergência: ganhar/perder a vida na periferia de São Paulo. São Paulo: Boitempo, 2011.

CALDEIRA, T. P. R. A política dos outros - o cotidiano dos moradores da periferia e o que pensam do poder e dos poderosos. São Paulo: Editora Brasiliense, 1984.

CERTEAU, M. A invenção do cotidiano. Vol 1. 21. ed. Petrópolis, RJ: Editora Vozes, 2014.

DARDEL, E. O homem e a terra: natureza da realidade geográfica. São Paulo: Perspectiva, 2011. 
DURHAM, E. R. A pesquisa antropológica com populações urbanas. In: A dinâmica da cultura: ensaios de antropologia. São Paulo: Cosac Naify, 2004.

Cultura e Ideologia. In: A dinâmica da cultura: ensaios de antropologia. São Paulo: Cosac Naify, 2004.

ECO, U. Como se faz uma tese. 24. ed. São Paulo: Perspectiva, 2012.

ESCAMES, E. F. Usina Parque: Aproveitamento e Valorização do Patrimônio Energético, Ambiental e Histórico da Usina Hidrelétrica Henry Borden. Dissertação de mestrado. Santo André: Curso de PósGraduação em Energia da Universidade Federal do ABC, 2011.

ELIAS, N.; SCOTSON, J. L. Os estabelecidos e os outsiders: sociologia das relações de poder a partir de uma pequena comunidade. Rio de Janeiro: Jorge Zahar, 2000.

FERRARA, L. N. Urbanização da natureza: da autoprovisão de infraestruturas aos projetos de recuperação ambiental nos mananciais do sul da metrópole paulistana. Tese de doutorado. São Paulo: Faculdade de Arquitetura e Urbanismo da Universidade de São Paulo, 2013.

FILARDO, A. Territórios da eletricidade - A Light em São Paulo e o Projeto da Serra de Cubatão - 19251950. Dissertação de mestrado. São Paulo: Faculdade de Arquitetura e Urbanismo da Universidade de São Paulo, 1999.

FIX, M. Parceiros da exclusão. Duas histórias da construção de uma "nova cidade" em São Paulo: Faria Lima e Água Espraiada. São Paulo: Boitempo, 2001.

FRANÇA, E. Favelas em São Paulo (1980-2008). Das propostas de desfavelamento aos projetos de urbanização. A Experiência do Programa Guarapiranga. Tese de doutorado. São Paulo: Faculdade de Arquitetura e Urbanismo da Universidade Presbiteriana Mackenzie, 2009.

FRANÇA, E. (Coord.). Guarapiranga - Recuperação urbana e ambiental no município de São Paulo. São Paulo: Marcos Carrilho Arquitetos, 2000.

FRÚGOLI JUNIOR, H. Sociabilidade urbana. Rio de Janeiro: Jorge Zahar Ed., 2007.

FRÚGOLI JUNIOR, H.; ANDRADE, L. T. de; PEIXOTO, F. A. (Org.). A cidade e seus agentes: práticas e representações. Belo Horizonte: PUCMinas/EDUSP, 2006.

GROSTEIN, M. D. A cidade clandestina: os ritos e os mitos - O papel da "irregularidade" na estruturação do espaço urbano no município de São Paulo 1900-1987. Tese de doutorado. São Paulo: Faculdade de Arquitetura e Urbanismo da Universidade de São Paulo, 1987.

HALBWACHS, M. Memória coletiva e memória histórica. In: A memória coletiva. Trad. L L. Schaffer. São Paulo: Vértice, pp. 53-89, 1990.

Memória coletiva e memória individual. In: A memória coletiva. Trad. L L. Schaffer. São Paulo: Vértice, pp. 25-52, 1990.

IKEMATSU, P. Conflitos e desafios na Gestão da Bacia Hidrográfica do Reservatório Guarapiranga. Dissertação (Mestrado em Paisagem e Ambiente) - Faculdade de Arquitetura e Urbanismo, Universidade de São Paulo, São Paulo, 2014.

JACOBS, J. Morte e vida de grandes cidades. 3. ed. São Paulo: Martins Fontes, 2013.

KOWARICK, L. Escritos Urbanos. São Paulo: Editora 34, 2000.

Viver em risco - sobre a vulnerabilidade socioeconômica e civil. São Paulo: Editora 34, 2009.

KOWARICK, L.; BRANT, V. (Coord.). São Paulo 1975: crescimento e pobreza. São Paulo: Edições Loyola, 1975. 
KOWARICK, L.; MARQUES, E. (Orgs.) São Paulo: Novos percursos e atores. São Paulo: Editora 34; Centro de Estudos da Metrópole, 2011.

MARTINS, M. L. R. R. Moradia e mananciais: tensão e diálogo na metrópole. São Paulo: Fauusp/Fapesp, 2006.

MARCONDES, M. J. A. Cidade e natureza - proteção dos mananciais e exclusão social. São Paulo: Studio Nobel/Edusp/Fapesp, 1990.

MENESES, U. B. A paisagem como fato cultural. In.: YÁZIGI, Eduardo (Org.). Turismo e Paisagem. São Paulo: Contexto, 2002, p. 29-64.

MEYER, R. M. P.; GROSTEIN, M. D.; BIDERMAN, C. São Paulo Metrópole. São Paulo: Editora da Universidade de São Paulo: Imprensa Oficial do Estado de São Paulo, 2004.

MINAYO, M. C. S. (Org.). Pesquisa social - teoria, método e criatividade. Petrópolis: Editora Vozes, 2012, Ed. 31 .

MIRANDA, M. E. Meio ambiente e Habitação Popular: o caso do Cantinho do Céu. Tese (Doutorado em Geografia Humana) - Faculdade de Filosofia Letras e Ciências Humanas, Universidade de São Paulo, São Paulo, 2002

MOREIRA, A. C. Política Pública de Proteção dos Mananciais. Dissertação de mestrado. São Paulo: Faculdade de Arquitetura e Urbanismo da Universidade de São Paulo, 1990.

PEREIRA, R. I. O sentido da paisagem e a paisagem consentida: projetos participativos na produção do espaço livre público. Tese de doutorado. FAUUSP, São Paulo, 2006.

OLIVEIRA, F. de; BRAGA, R.; RIZEK, C. (Orgs.) Hegemonia às avessas. São Paulo: Boitempo Editorial, 2010.

POLLI, S. A. Moradia e meio ambiente - Os conflitos pela apropriação do território nas áreas de mananciais de São Paulo. Tese (Doutorado em Planejamento Urbano e Regional) - Instituto de Pesquisa e Planejamento Urbano e Regional da Universidade Federal do Rio de Janeiro, Rio de Janeiro, 2010.

RADOLL, G. R. A criação do Parque Natural Municipal Itaim e sua potencialidade como catalisador de transformações socioambientais. Dissertação (Mestrado em Paisagem e Ambiente) - Faculdade de Arquitetura e Urbanismo, Universidade de São Paulo, São Paulo, 2014.

RICHARDS, D. L. Regularização de assentamentos precários em áreas de mananciais - avanços, desafios e perspectivas para a cidade de São Paulo (1997-2010). Dissertação de mestrado. Faculdade de Arquitetura e Urbanismo da Universidade Presbiteriana Mackenzie, São Paulo, 2011.

ROLNIK, R. A cidade e a lei - Legislação, política urbana e territórios na cidade de São Paulo. São Paulo: Studio Nobel/Fapesp, 2003.

SADER, E. Quando novos personagens entraram em cena - Experiências e lutas dos trabalhadores da Grande São Paulo 1970-1980. São Paulo: Paz e Terra, 1988.

SANDEVILLE JR, E. Paisagens e Métodos. Algumas considerações para a elaboração de roteiros de estudo na paisagem intra-urbana. In.: Paisagens em Debate. São Paulo FAUUSP, v.2, p.1, 2004. Disponível em: http://www.usp.br/fau/depprojeto/gdpa/paisagens

Paisagem. São Paulo: Paisagem e Ambiente n. 20, 2005, pg. 47-59.

Paisagens partilhadas. São Paulo: Paisagem e Ambiente, n. 30, 2012.

SANDEVILLE, E; ANGILELI, C. M. de M. Quando a casa vira parque. Anais ANPUR, vol. 15, 2013.

SANTOS, C. N. F. Como e quando pode um arquiteto virar antropólogo? In.: VELHO, Gilberto (org). Desafio da Cidade. Rio de Janeiro, Editora Campus, 1980, p-37-57.

Movimentos urbanos no Rio de Janeiro. Rio de Janeiro: Zahar Editores, 1981. 
SANTOS, C. N. F.; VOGEL, A. (Coord.) Quando a rua vira casa - A apropriação de espaços de uso coletivo em um centro de bairro. 2. ed. rev e atualizada. Rio de Janeiro: FINEP/IBAM, 1981.

SANTOS, M. S. A construção social da memória. In.: Memória Coletiva \& Teoria Social. São Paulo: Annablume, pp. 33-92, 2003.

SANTORO, P. F; FERRARA, L. N.; WHATELY, M. (Orgs). Mananciais: diagnóstico e políticas habitacionais. São Paulo: Instituto Socioambiental, 2008.

SÃO PAULO (Estado). Cadernos de Educação Ambiental - Edição Especial Mananciais Billings, vol I. São Paulo: Secretaria do Meio Ambiente / Coordenadoria de Educação Ambiental, 2010. Disponível em www.ambiente.sp.gov.br/cea.

SÃO PAULO (Estado). Região Metropolitana de São Paulo - Proteção aos Mananciais: legislação e roteiro para implantação de projetos. São Paulo: Emplasa, 1984.

SÃO PAULO (Estado). Relatório Qualidade das Águas Superficiais do Estado de São Paulo 2013. São Paulo: CETESB, 2014. Disponível em www.cetesb.sp.gov.br/agua/aguas-superficiais/35-publicacoes-/relatorios.

SÃO PAULO (Município). CATÁLOGO da Exposição no Museu da Casa Brasileira: A Cidade Informal no Século XXI. 3. ed, Secretaria Municipal de Habitação, 2011.

SÃO PAULO (Município). Meu bairro, minha cidade - CEU Navegantes - Grajaú/Cantinho do Céu. Secretaria Municipal de Educação, 2004.

SEABRA, O. C. de L. Os meandros dos rios nos meandros do poder. Tietê e Pinheiros - Valorização dos rios e das várzeas na cidade de São Paulo. 1987. Tese (Doutorado em Geografia) - Faculdade de Filosofia, Letras e Ciências Humanas, Universidade de São Paulo, São Paulo, 1987.

SILVA, E. A. Governar o ingovernável: gestão da irregularidade urbana em áreas de mananciais em São Paulo. 2011. Tese (Doutorado em Sociologia) - Faculdade de Filosofia, Letras e Ciências Humanas, Universidade de São Paulo, São Paulo, 2011.

SILVEIRA, L. Política e Território: etnografia das práticas políticas dos membros de uma Associação de Moradores do Grajaú. Dissertação (Mestrado em Antropologia Social) - Faculdade de Filosofia, Letras e Ciências Humanas, Universidade de São Paulo, São Paulo, 2014.

SÓCRATES, J. R.; GROSTEIN; M. D.; TANAKA, M. M. S. A cidade invade as águas: qual a questão dos mananciais? São Paulo: Faculdade de Arquitetura e Urbanismo da Universidade de São Paulo, 1985.

TORRES, H. ; MARQUES, E. C. ; BICHIR, R. . Políticas públicas, pobreza urbana e segregação residencial. In: CUNHA, J. M. P. da (Org.). Novas metrópoles paulistas: população, vulnerabilidade e segregação. Campinas: Editora da Unicamp, 2006, v. 1, p. 231-252.

VALLADARES, L. do P. A invenção da favela - Do mito de origem a favela.com. Rio de Janeiro: Editora FGV, 2005.

Passa-se uma casa - Análise do Programa de Remoção de Favelas do Rio de Janeiro. Rio de Janeiro: Zahar Editores, 1978.

VELHO, G. Observando o familiar. In.: Um antropólogo na cidade - ensaios de antropologia urbana. Rio de Janeiro: Zahar, p. 69-79, 2013.

VILLAÇA, F. Espaço intra-urbano no Brasil. São Paulo: Nobel: Fapesp: Lincoln Institute, 2. ed., 2001.

VILLAÇA, F. Metodologia de pesquisa. In.: Revista Oculum Ensaios 09_10. Campinas: PUCCamp, 2009.

Reflexões sobre as cidades brasileiras. São Paulo: Studio Nobel, 2012. 
VILLAS BOAS, R. Morar ou Preservar? Conflitos e negociações na preservação das áreas de mananciais na gestão municipal de Luiza Erundina. In.: São Paulo: conflitos e negociações na disputa pela cidade. São Paulo: Publicações Pólis, No. 23, p. 43-74, 1995.

WERTHMANN, C. Operações táticas na cidade informal: o caso do Cantinho do Céu. São Paulo: Prefeitura do Município de São Paulo. Secretaria Municipal de Habitação - SEHAB, 2009.

WHATELY, M.; SANTORO, P. F.; FERRARA, L. N.; BAJESTEIRO, F. B. (Orgs). Mananciais: uma nova realidade? São Paulo: Instituto Socioambiental, 2008.

WHATELY, M. Contribuições para a elaboração de leis específicas de mananciais: o exemplo da Billings. São Paulo: Instituto Socioambiental, 2008.

YAZAKI, L. F. O. de L. Ações de saneamento ambiental para recuperação e proteção dos mananciais. In.: WHATELY, Marussia et al. Mananciais uma nova realidade? São Paulo, Instituto Socioambiental, 2008.

\section{LEGISLAC̣̃̃o}

\section{MUNICIPAL}

Lei Municipal nº 8.769/1978 - zoneamento área de mananciais

Lei Municipal n 9.413/1981 - Lei de Parcelamento do Solo

Lei Municipal n 13.430/2002 - Plano Diretor Estratégico do Município de São Paulo

Decreto Municipal $\mathrm{n}^{\circ}$ 13.885/2004 - Estabelece normas complementares ao Plano Diretor Estratégico, institui os Planos Regionais Estratégicos das Subprefeituras, dispõe sobre o parcelamento, disciplina e ordena o Uso e Ocupação do Solo do Município de São Paulo

Resolução CONPRESP 18/2004 - Tombamento de polígono no bairro de Interlagos

Decreto Municipal n 53.380/12 - cria e denomina o Parque Cantinho do Céu

Lei Municipal n 16.050/2014 - Plano Diretor Estratégico do Município de São Paulo

\section{EstADUAL}

Decreto Estadual n 6.983, de 22 de fevereiro de 1935 - Extingue o município de Santo Amaro, cujo território passa a fazer parte do município da Capital.

Lei Estadual n 898/1975 - Lei de Proteção aos Mananciais

Lei Estadual n 1.172/1976 - Lei de Proteção aos Mananciais

Decreto Estadual n 9.714/1977 - Regulamentação da Lei de Proteção aos Mananciais

Lei Estadual n 7.663, de 30 de dezembro de 1991 - Estabelece normas de orientação à Política Estadual de Recursos Hídricos bem como ao Sistema Integrado de Gerenciamento de Recursos Hídricos.

Lei Estadual n 9.034, de 29 de dezembro de 1994 - Dispõe sobre o Plano Estadual de Recursos Hídricos PERH, a ser implantado no período 1994 e 1995, em conformidade com a Lei 7.663, de 30/12/91, que instituiu normas de orientação à Política Estadual de Recursos Hídricos

Lei Estadual n 9.866, de 28 de novembro de 1997 - Dispõe sobre diretrizes e normas para a proteção e recuperação das bacias hidrográficas dos mananciais de interesse regional do Estado de São Paulo

Decreto Estadual n 43.022, de 7 de abril de 1998 - Plano Emergencial de Recuperação dos Mananciais

Lei Estadual n 13.579, de 13 de julho de 2009 - Define a Área de Proteção e Recuperação dos Mananciais da Bacia Hidrográfica do Reservatório Billings - APRM-B, e dá outras providências correlatas 
Decreto Estadual n 55.342, de 13 de janeiro de 2010 - Regulamenta dispositivos da Lei no 13.579, de 13 de julho de 2009, que define a Área de Proteção e Recuperação dos Mananciais da Bacia Hidrográfica do Reservatório Billings - APRM-B, e dá providências correlatas

Decreto Estadual $\mathrm{n}^{\circ}$ 56.635, de $1^{\circ}$. de janeiro de 2011 - Dispõe sobre as alterações de denominação e transferências que especifica, define a organização básica da Administração Direta e suas entidades vinculadas e dá providências correlatas

Resolução SMA n 25, de 10 de abril de 2013 - disciplina o licenciamento ambiental dos Programas de Recuperação de Interesse Social (PRIS) no âmbito da Legislação Estadual de Proteção e Recuperação dos Mananciais das Bacias Hidrográficas dos Reservatórios Billings e Guarapiranga.

\section{Federal}

Decreto-lei nº 2.848, de 7 de dezembro de 1940. Código Penal.

Lei Federal n 6.766, de 19 de dezembro de 1979. Lei de Parcelamento do Solo.

Constituição Federal de 1988.

Lei Federal n ${ }^{\circ} 10.257$, de 10 de julho de 2001. Regulamenta os Arts. 182 e 183 da Constituição Federal, estabelece diretrizes gerais da política urbana e dá outras providências.

Lei Federal $\mathrm{n}^{\circ} 10.803$, de 11 de dezembro de 2003. Altera o art. 149 do Decreto-Lei no 2.848, de 7 de dezembro de 1940 - Código Penal, para estabelecer penas ao crime nele tipificado e indicar as hipóteses em que se configura condição análoga à de escravo.

\section{NOTÍCIAS DE JORNAL}

O Estado de São Paulo. Caderno Cidades, 06/10/1998 - "Estado quer urbanizar 313 bairros clandestinos".

O Estado de São Paulo. Caderno Cidades, 12/11/1998 - "Moradores impedem demolição na Billings".

O Estado de São Paulo, Caderno Cidades, 17/02/2004 - "Assessor de deputado é morto a tiros".

O Estado de São Paulo. Caderno Metrópole, 08/09/20012 - "Kassab libera R\$ 3 bi para reurbanizar 118 favelas e recuperar orla de represas". 


\section{LISTAS}

\section{Lista de Abreviaturas e Siglas}

ACP - Ação Civil Pública

APP - Área de Preservação Permanente

APM - Área de Proteção aos Mananciais

APRM - Área de Proteção e Recuperação dos Mananciais

APRM-B - Área de Proteção e Recuperação dos Mananciais da Bacia Hidrográfica do Reservatório Billings

APRM-G - Área de Proteção e Recuperação dos Mananciais da Bacia Hidrográfica do Guarapiranga

ARA - Área de Recuperação Ambiental

BIRD - Banco Internacional para a Reconstrução e o Desenvolvimento - Banco Mundial.

BNH - Banco Nacional de Habitação

CDHU - Companhia Estadual de Desenvolvimento Habitacional e Urbano

CEDECA - Centro de Defesa da Criança e Adolescente

CETESB - Companhia Ambiental do Estado de São Paulo

CEI - Centro de Educação Infantil

CEF - Caixa Econômica Federal

CEU - Centro Educacional Unificado

COHAB - Companhia Metropolitana de Habitação de São Paulo

CONPRESP - Conselho Municipal de Preservação do Patrimônio Histórico, Cultural e Ambiental da Cidade de São

Paulo

CPTM - Companhia Paulista de Trens Metropolitanos

CRI - Cartório de Registro de Imóveis

DUP - Decreto de Utilidade Pública

DUSM - Departamento de Uso do Solo Metropolitano

EE - Escola Estadual

EEE - Estação Elevatória de Esgoto

EMAE - Empresa Metropolitana de Águas e Energia S.A.

EMEI - Escola Municipal de Educação Infantil

EMEF - Escola Municipal de Educação Fundamental

EMPLASA - Empresa Paulista de Planejamento Metropolitano

EMTU - Empresa Metropolitana de Transportes Urbanos

GEGRAN - Grupo Executivo da Grande São Paulo

GESP - Governo do Estado de São Paulo

HABISP - Sistema de Informações para Habitação Social na Cidade de São Paulo

HIS - Habitação de Interesse Social

IAB - Instituto de Arquitetos do Brasil

LABCIDADE - Laboratório de Espaço Público e Direito à Cidade

LEPAC - Levantamento Planialtimétrico Cadastral

LPM - Lei de Proteção aos Mananciais

MP/ MPSP - Ministério Público de São Paulo

NEP - Núcleo de Estudos da Paisagem

O.C.A. - Ocupação Comunitária Alternativa

ONG - Organização não governamental

PDPA - Plano de Desenvolvimento e Proteção Ambiental

PMSP - Prefeitura Municipal de São Paulo

PNH - Política Nacional de Habitação

PDE - Plano Diretor Estratégico

PRE - Plano Regional Estratégico

PRIS - Programa de Recuperação de Interesse Social

RMSP - Região Metropolitana de São Paulo

SABESP - Companhia de Saneamento de São Paulo

SEHAB - Secretaria Municipal de Habitação

SSE - Secretaria Estadual de Saneamento e Energia

SSRH - Secretaria Estadual de Saneamento e Recursos Hídricos

SMA - Secretaria Estadual de Meio Ambiente 
SVMA - Secretaria Municipal do Verde e Meio Ambiente

TAC - Termo de Ajustamento de Conduta

UBS - Unidade Básica de Saúde

UGRHI - Unidade de Gerenciamento de Recursos Hídricos

UH - Unidade Habitacional

VFP - Vara da Fazenda Pública

ZEIS - Zona Especial de Interesse Social

\section{Lista de Figuras}

Figura 1 - Bairros estudados no Complexo Cantinho do Céu.

Figura 2 - A rede de interlocutores.

Figura 3 - COHAB Brigadeiro Faria Lima. Crédito: Melissa Matsunaga, 2014.

Figura 4 - Perspectiva esquemática sobre a aplicação da LPM - áreas de primeira e segunda categoria. Fonte: São Paulo, 1984.

Figura 5 - Foto histórica de 1962 com sobreposição do perímetro de intervenção do Complexo Cantinho do Céu. Fonte: Laboratório de Aerofotogrametria e Sensoriamento Remoto - Arquivo de Fotografias Aéreas - Departamento de Geografia. FFLCH-USP. Elaboração: MATSUNAGA (2015).

Figura 6 - Foto histórica de 1972 com sobreposição do perímetro de intervenção do Complexo Cantinho do Céu. Fonte: Laboratório de Aerofotogrametria e Sensoriamento Remoto - Arquivo de Fotografias Aéreas - Departamento de Geografia. FFLCH-USP. Elaboração: MATSUNAGA (2015).

Figura 7 - Fotoíndice recobrimento aerofotogramétrico - 1986-1989 - Eletropaulo com sobreposição do perímetro de intervenção do Complexo Cantinho do Céu. Fonte: Laboratório de Aerofotogrametria e Sensoriamento Remoto Arquivo de Fotografias Aéreas - Departamento de Geografia. FFLCH-USP. Elaboração: MATSUNAGA (2015).

Figura 8- Foto histórica de 1994 com sobreposição do perímetro de intervenção do Complexo Cantinho do Céu. Fonte: Laboratório de Aerofotogrametria e Sensoriamento Remoto - Arquivo de Fotografias Aéreas - Departamento de Geografia. FFLCH-USP. Elaboração: MATSUNAGA (2015).

Figura 9 - Foto histórica de 2011 com sobreposição do perímetro de intervenção do Complexo Cantinho do Céu. Fonte: Laboratório de Aerofotogrametria e Sensoriamento Remoto - Arquivo de Fotografias Aéreas - Departamento de Geografia. FFLCH-USP. Elaboração: MATSUNAGA (2015).

Figura 10 - Linhas de alta tensão no acesso ao bairro Parque Residencial dos Lagos. Crédito: Melissa Matsunaga, 2013. 58

Figura 11 - Esquematização temporal dos domínios fundiários e evolução da ocupação. Fonte: Informações de fotos aéreas dos anos de 1962, 1972, 1994 (Laboratório de Aerofotogrametria e Sensoriamento Remoto - Arquivo de fotografias aéreas - Depto de Geografia/FFLCH-USP); Foto aérea de 1986: BASE Aerofotogrametria e Projetos, constante em Barda e França (2012:76); Matrículas 11 CRI constantes no processo judicial da ACP, volumes 2 e 18; Imagem de capa Revista VEJA SP de 19/06/1991 - ver Anexo 2. Base cartográfica: CESAD/USP. Elaboração: MATSUNAGA (2015).

Figura 12 - Notícia do jornal "Moradores impedem demolição na Billings". Fonte: O Estado de São Paulo de 12 de novembro de 1998. Caderno Cidades.

Figura 13 - Etapas do Projeto de Urbanismo do Complexo Cantinho do Céu. Fonte: Boldarini Arquitetura e Urbanismo 64

Figura 14 - Trechos do Projeto de Paisagismo (parque linear) do Complexo Cantinho do Céu. Fonte: Boldarini Arquitetura e Urbanismo

Figura 15 - Recursos investidos no Programa Mananciais. Fonte: Notícia "Kassab libera R\$3bi para reurbanizar 118 favelas e recuperar orla de represas", Jornal O Estado de São Paulo, Caderno Metrópole, 08 set 2012.

Figura 16- Localização do Complexo Cantinho do Céu. Sem escala. Base cartográfica: CESAD/FAUUSP. Elaboração: MATSUNAGA (2015).

Figura 17 - Índice Paulista de Vulnerabilidade Social - IPVS 2010. Fonte: IBGE, CENSO 2010; Fundação SEADE, IPVS 2010, 2013. Organização: MATSUNAGA (2015).

Figura 18 - Vivenciadores entrevistados e status das remoções no início da pesquisa de campo em janeiro de 2013. Fonte: Base cartográfica: CESAD/FAUUSP; Remoções: BARDA \& FRANÇA, 2012. Elaboração: MATSUNAGA (2015). 70

Figura 19 - Equipamentos e acessos principais aos bairros da Península do Cocaia. Base cartográfica: CESAD/FAUUSP.Elaboração: MATSUNAGA (2015). 
Figura 20 - Delimitação aproximada das glebas e domínios fundiários. FONTE: Cantinho do Céu: 18o volume do Processo Judicial. Residencial dos Lagos: entrevistas e depoimentos. Base: CESAD/FAUUSP. Elaboração: MATSUNAGA (2015).

Figura 21 - Conversa coletiva em março de 2013 na residência de Dona Rosa. Crédito: Melissa Matsunaga, 2013.

Figura 22 - Habilitação de barco e carteira de pescador de Seo João. Crédito: Melissa Matsunaga , 2013.

Figura 23 - Seo João em passeio de barco na primeira entrevista. Crédito: Melissa Matsunaga , 2013.

Figura 24 - Ângela soltando a rede na represa. Crédito: Melissa Matsunaga , 2014.

Figura 25 - Locais de moradia de Seo João e Angela.

Figura 26 - Planta utilizada na venda dos lotes - gleba Lago Azul. Fonte: Processo administrativo 1988-0-000-987-5 Programa Mananciais/SEHAB-PMSP.

Figura 27 - Nomeação das ruas com nomes de pássaros realizada pelos moradores. Elaboração: MATSUNAGA (2015).

Figura 28 - Vera e vazamento de esgoto na rede da Sabesp. Crédito: Melissa Matsunaga, 2013.

Figura 29 - Dona Lourdes em sua casa, 73 anos. Crédito: Melissa Matsunaga, 2013.

Figura 30 - Dona Lourdes em sua casa à Rua João Bernardo Mendonça, nome de seu falecido marido. Crédito: Melissa Matsunaga, 2013.

Figura 31 - Locais de moradia de Dona Lourdes.

Figura 32- Ampliação da residência e comércio lindeiro ao parque. Crédito: Melissa Matsunaga, 2013.

Figura 33 - Reforma e pintura de residência em frente ao parque. Crédito: Melissa Matsunaga, 2013.

Figura 34 - Implantação do Projeto Executivo de Paisagismo do Complexo Cantinho do Céu. Parque Trecho 1 Residencial dos Lagos. Fonte: Boldarini Arquitetura e Urbanismo.

Figura 35 - Container instalado pela SVMA e abandonado, em maio de 2013. Crédito: Melissa Matsunaga, 2013.1106

Figura 36 - Trecho sem manutenção com acúmulo de lixo, em fevereiro de 2014. Crédito: Melissa Matsunaga, 2014.106

Figura 37 - Cine OCA - 29/08/2014 - Exibição do documentário sobre as APAs. Crédito: Melissa Matsunaga, 2014. 108

Figura 38 - Faixa em agradecimento a políticos locais na esquina das ruas Pedro Escobar e Mâncio Lima após obras de recapeamento asfáltico, abril de 2014. Crédito: Melissa Matsunaga, 2014.

Figura 39 - Destinos localizados em relação às remoç̃es realizadas até 2012 no bairro Parque Residencial dos Lagos com sobreposição aos assentamentos precários (loteamentos irregulares, favelas e núcleos urbanizados). Fontes: lista de atendimentos fornecida pela SEHAB/PMSP em julho de 2013 e HABISP/PMSP. Elaboração: MATSUNAGA (2015).

Figura 40 - Lucia e sua casa à rua Cairu. Crédito: Melissa Matsunaga, 2013.

Figura 41 - Lucia e o local da sua segunda moradia (entre 2009 e 2011) no bairro Cantinho do Céu, de onde foi removida. Crédito: Melissa Matsunaga, 2013.

Figura 42 - Locais de moradia de Lucia.

Figura 43 - Rua Porto Seguro no Cantinho do Céu. A residência interditada de Débora é nos fundos do n²12. Crédito: Melissa Matsunaga, 2013.

Figura 44 - Croqui de campo. Planta da casa de Débora. Elaboração: MATSUNAGA (2013).

Figura 45 - Residência de Débora interditada pela Defesa Civil em junho de 2012, à Rua Porto Seguro, 212. Crédito: Melissa Matsunaga, 2013.

Figura 46 - Nova residência de Débora à rua Canário. Crédito: Melissa Matsunaga, 2014.

Figura 47 - Locais de moradia de Débora.

Figura 48 - Seo Pedro indicando a até onde vai o antigo lote do pai, englobando a casa verde, onde mora a madrasta. Crédito: Melissa Matsunaga, 2013.

Figura 49 - Primeira conta de luz de Seo Pedro, de junho de 2013, no valor de $R \$ 23,55$. Crédito: Melissa Matsunaga, 2013.

Figura 50 - Rua Bonfim na altura da casa de Seo Pedro. Crédito: Melissa Matsunaga, 2013.

Figura 51 - Seo Pedro, Cleonice e o bebê Fabrício, que nasceu em 2014, durante o período da pesquisa de campo. Crédito: Melissa Matsunaga, 2014.

Figura 52 - Locais de moradia de Seo Pedro 140

Figura 53 - Localização do Residencial Mata Virgem e bairro Lago Azul em APRM-B. 
Figura 54 - Localização do Conjunto Residencial Mata Virgem junto à divisa de Diadema. FONTE: Google Earth, 2014. Elaboração: MATSÚNAGA (2015).

Figura 55 - Quintal da casa removida no Lago Azul. Acervo de Lucilene. 145

Figura 56 - Apartamento de Lucilene mobiliado e decorado. Crédito: Melissa Matsunaga, 2014.

Figura 57 - Comunicados de acompanhamento da equipe social da SEHAB junto ao condomínio. Crédito: Melissa Matsunaga, 2014.

Figura 58 - Portaria do condomínio, local de. de Lucilene. Crédito: Melissa Matsunaga, 2014.

Figura 59 - Área de lazer e recreação do condomínio. Crédito: Melissa Matsunaga, 2014.

Figura 60 - Locais de moradia de Lucilene. 150

Figura 61 - Quarto da residência de Fátima. Crédito: Melissa Matsunaga, 2013.

\section{LISTA DE GRÁFICOS}

Gráfico 1 - Tipo de atendimento no bairro Parque Residencial dos Lagos até 2012.

\section{LISTA DE QUadros}

Quadro 1 - Total de domicílios e habitantes em Assentamentos precários - São Paulo, 2008. Fonte: Habisp: Mapeando a habitação na cidade de São Paulo. Secretaria de Habitação. Superintendência de Habitação Popular. São Paulo, 2008:58

Quadro 2 - Legislação incidente e Projeto de Urbanização e Obras no Complexo Cantinho do Céu.

Quadro 3 - Atendimentos no Complexo Cantinho do Céu até 2012. Elaboração: MATSUNAGA (2015) a partir de lista de atendimentos fornecida pela SEHAB em 2013.

Quadro 4 - Qualificação dos destinos informados em lista de atendimentos no bairro Residencial dos Lagos até 2012. Elaboração: MATSUNAGA (2015) a partir de lista de atendimentos fornecida pela SEHAB em 2013. 


\section{APÊNDICES}

\section{APÊNDICE 1}

175

Atividades de Campo

\section{APÊNDICE 2}

179

Processo judicial No. 0405292-44.1997.8.26.0053 (336/97)

referente à Ação Civil Pública ajuizada pelo Ministério Público de São Paulo em fevereiro de 1997

\section{APÊNDICE 3}

189

Oficina de Mapeamento com alunos da EE Maria Luiza realizada em abril e maio de 2014

\section{APÊNDICE 4}

205

Publicações, exposições e prêmios referentes à intervenção urbana realizada (política pública, programa, projeto, obra) 



\section{APÊNDICE 1}

\section{Atividades de Campo}

As atividades de campo realizadas entre janeiro de 2013 e outubro de 2014 estão listadas a seguir:

\begin{tabular}{|c|c|c|c|c|}
\hline & DIA & LOCAL & INTERLOCUTOR(ES) & ATIVIDADE \\
\hline 1 & 06/01/13 dom & $\begin{array}{l}\text { Casinha das mães - } \\
\text { Cantinho do Céu }\end{array}$ & $\begin{array}{l}\text { Laís - antropóloga, mestranda da } \\
\text { FFLCH, Carol e demais } \\
\text { participantes de coletivo de jovens }\end{array}$ & $\begin{array}{l}\text { Mutirão de cobertura para a sede Casinha das } \\
\text { mães - espaço de articulação de jovens. }\end{array}$ \\
\hline 2 & 03/02/13 dom & $\begin{array}{l}\text { Rua Francisco Inácio } \\
\text { Solano }\end{array}$ & \multicolumn{2}{|c|}{ Manifestação pela construção de UBS no bairro } \\
\hline 3 & 03/02/13 dom & Parque do Lago Azul & $\begin{array}{l}\text { Dona Vera - presidente da } \\
\text { Associação dos moradores do Lago } \\
\text { Azul }\end{array}$ & $\begin{array}{l}\text { Conversa inicial para apresentação da } \\
\text { pesquisadora e intenções da pesquisa. }\end{array}$ \\
\hline 4 & $22 / 02 / 13$ sex & $\begin{array}{l}\text { Residência de Dona } \\
\text { Rosa no Cantinho do } \\
\text { Céu (Rua } 15 \text { de } \\
\text { novembro, 59) }\end{array}$ & $\begin{array}{l}\text { Dona Rosa - liderança do Cantinho } \\
\text { do Céu }\end{array}$ & $\begin{array}{l}\text { Conversa inicial para apresentação da } \\
\text { pesquisadora e intenções da pesquisa. }\end{array}$ \\
\hline 5 & 02/03/13 sáb & $\begin{array}{l}\text { Residência de Dona } \\
\text { Rosa no Cantinho do } \\
\text { Céu (Rua } 15 \text { de } \\
\text { novembro, 59) }\end{array}$ & $\begin{array}{l}\text { B. Dona Rosa - liderança do } \\
\text { Cantinho do Céu } \\
\text { Dona Florípes - liderança do } \\
\text { Cantinho do Céu } \\
\text { Roseli - moradora do Cantinho do } \\
\text { Céu } \\
\text { Lucia - moradora do Cantinho do } \\
\text { Céu (foi removida pelo projeto e } \\
\text { voltou para o bairro) } \\
\text { Marcos - morador do Cantinho do } \\
\text { Céu } \\
\text { Heloísa - moradora do Cantinho do } \\
\text { Céu } \\
\text { Domingas - moradora do Cantinho } \\
\text { do Céu e agente de saúde }\end{array}$ & $\begin{array}{l}\text { Conversa com moradores antigos sobre } \\
\text { quando se mudaram para o bairro. }\end{array}$ \\
\hline 6 & 22/04/13 sáb & CEU Dutra & \multicolumn{2}{|c|}{ Audiência pública do Plano de Metas 2013-2016 - Subprefeitura Capela do Socorro } \\
\hline 7 & $\begin{array}{l}17 / 03 / 13 \text { dom e } \\
27 / 03 / 13 \text { qua }\end{array}$ & CEU Navegantes & $\begin{array}{l}\text { Adolfo - coordenador cultural do } \\
\text { CEU }\end{array}$ & $\begin{array}{l}\text { Entrevista realizada em dois dias, com relato } \\
\text { de várias atividades promovidas no CEU e } \\
\text { história de vida do interlocutor. }\end{array}$ \\
\hline 8 & 11/05/13 sáb & Jd Prainha & $\begin{array}{l}\text { Dona Rosa - liderança do Cantinho } \\
\text { do Céu } \\
\text { Malufinho - liderança amigo de } \\
\text { Dona Rosa } \\
\text { Dorinha - liderança amiga de Dona } \\
\text { Rosa }\end{array}$ & $\begin{array}{l}\text { Visita ao Jd Prainha em busca da liderança do } \\
\text { bairro Seo Manoel ou Rufino. Encontramos } \\
\text { apenas Seo Manoel no caminho, com quem } \\
\text { fiquei de reestabelecer contato em outro } \\
\text { momento. }\end{array}$ \\
\hline 9 & $21 / 05 / 13$ ter & $\begin{array}{l}\text { SEHAB } \\
\text { Martinelli }\end{array}$ & Arquiteta Violeta Kubrusly & $\begin{array}{l}\text { Depoimento sobre o histórico do projeto dentro } \\
\text { da SEHAB e envolvimento da arquiteta nos } \\
\text { procedimentos de aprovação e regularização } \\
\text { fundiária. }\end{array}$ \\
\hline 10 & 31/05/13 sáb & Parque do Lago Azul & $\begin{array}{l}\text { Dona Vera - presidente da } \\
\text { Associação dos moradores do Lago } \\
\text { Azul }\end{array}$ & $\begin{array}{l}\text { Conversa com o intuito de retomar o contato } \\
\text { após contatos iniciais em outros bairros. Breve } \\
\text { relato sobre a história de vida dela. }\end{array}$ \\
\hline 11 & 31/05/13 sáb & Residencia de Fatima & Fátima - moradora do Lago Azul & $\begin{array}{l}\text { Breve conversa sobre a situação de risco de } \\
\text { desabamento da moradia. }\end{array}$ \\
\hline
\end{tabular}




\begin{tabular}{|c|c|c|c|c|}
\hline 12 & 22/06/13 sáb & $\begin{array}{l}\text { Residência de Dona } \\
\text { Lourdes no Lago Azul }\end{array}$ & $\begin{array}{l}\text { Dona Lourdes - moradora antiga do } \\
\text { Lago Azul }\end{array}$ & $\begin{array}{l}\text { Entrevista individual aberta com enfoque para } \\
\text { história de vida e sua relação com o bairro. }\end{array}$ \\
\hline 13 & 02/07/13 ter & $\begin{array}{l}\text { Residência de Seu } \\
\text { Pedro - Cantinho do } \\
\text { Céu }\end{array}$ & $\begin{array}{l}\text { Seu Pedro - morador do Cantinho } \\
\text { do Céu }\end{array}$ & $\begin{array}{l}\text { Entrevista individual aberta com enfoque para } \\
\text { seus planos tendo em vista que está prevista a } \\
\text { remoção de sua casa. }\end{array}$ \\
\hline 14 & 09/07/13 ter & $\begin{array}{l}\text { Residência de Lucia - } \\
\text { Cantinho do Céu }\end{array}$ & $\begin{array}{l}\text { Lucia - moradora do Cantinho do } \\
\text { Céu }\end{array}$ & $\begin{array}{l}\text { Entrevista individual aberta com enfoque para } \\
\text { história de vida e seu deslocamento no bairro, } \\
\text { já que foi removida pelo projeto. }\end{array}$ \\
\hline 15 & $16 / 07 / 13$ ter & Parque do Lago Azul & $\begin{array}{l}\text { Dona Vera - presidente da } \\
\text { Associação dos moradores do Lago } \\
\text { Azul }\end{array}$ & $\begin{array}{l}\text { Conversa sobre o parque e sua gestão. } \\
\text { Aproveitamos a presença de dois moradores } \\
\text { (Seu Manoel e Seu Cunha) que estavam } \\
\text { cuidando de algumas crianças que brincavam } \\
\text { no Parque para conversar brevemente sobre } 0 \\
\text { bairro. }\end{array}$ \\
\hline 16 & 23/07/13 ter & $\begin{array}{l}\text { Almoço no Centro de } \\
\text { SP }\end{array}$ & Sirlene - arquiteta da JNS & Conversa sobre possíveis contatos na SEHAB. \\
\hline 17 & 25/07/13 qui & $\begin{array}{l}\text { Ligação telefônica à } \\
\text { SVMA }\end{array}$ & Guilherme & $\begin{array}{l}\text { Esclarecimento sobre andamento da } \\
\text { manutenção e gestão do Parque Linear do } \\
\text { Cantinho do Céu. }\end{array}$ \\
\hline 18 & 27/07/13 sáb & $\begin{array}{l}\text { Residência de Seo } \\
\text { João do Peixe }\end{array}$ & $\begin{array}{l}\text { Seo João do Peixe - morador antigo } \\
\text { do Cantinho do Céu }\end{array}$ & $\begin{array}{l}\text { Entrevista com pescador sobre o bairro e sua } \\
\text { vida. }\end{array}$ \\
\hline 19 & $\begin{array}{l}01-06-07-08-09- \\
20-22- \\
23 / 08 / 2013\end{array}$ & Fórum Helly Lopes & Processo judicial & $\begin{array}{l}\text { Consulta ao processo judicial aberto com Ação } \\
\text { Civil Pública pela Promotoria que provocou as } \\
\text { obras no Cantinho do Céu. }\end{array}$ \\
\hline 20 & $12 / 08 / 13 \mathrm{seg}$ & CEU Navegantes & $\begin{array}{l}\text { Marcelo - coordenador educacional } \\
\text { CEU }\end{array}$ & $\begin{array}{l}\text { Contato para oficina de mapeamento a ser } \\
\text { realizada no CEU. }\end{array}$ \\
\hline 21 & 12/08/13 seg & Residência de Debora & Debora & $\begin{array}{l}\text { Apresentação da pesquisadora e início de } \\
\text { acompanhamento sobre demarcação de sua } \\
\text { residência como área de risco. }\end{array}$ \\
\hline 22 & $13 / 08 / 13$ ter & $\begin{array}{lrr}\text { Sala da } & \text { Profa. } & \text { Maria } \\
\text { Eliza, } & \text { deptor de } \\
\text { Geografia } & - & \text { FFLCH- } \\
\text { USP } & & \end{array}$ & Prof Dra. Maria Eliza Miranda & $\begin{array}{l}\text { Conversa sobre a tese da Prof, finalizada em } \\
2002 \text { que aborda aspectos políticos do } \\
\text { processo de constituição do Cantinho do Céu e } \\
\text { alternativas para a regularização de acordo } \\
\text { com LPM 75/76. }\end{array}$ \\
\hline 23 & $27 / 08 / 13$ ter & $\begin{array}{l}\text { SEHAB } \\
\text { Martinelli }\end{array}$ & $\begin{array}{l}\text { Rita - coordenadora do social do } \\
\text { Programa Mananciais }\end{array}$ & $\begin{array}{l}\text { Obtenção de lista completa de atendimentos } \\
\text { realizados no Núcleo Cantinho do Céu até } \\
2012 \text {. }\end{array}$ \\
\hline 24 & $\begin{array}{l}\text { 28-31/08/13 } \\
\text { qua/sáb }\end{array}$ & $\begin{array}{l}\text { SESC Interlagos e } \\
\text { EMAE }\end{array}$ & $\begin{array}{l}\text { Arquiteto Escames - EMAE e Danilo } \\
\text { - morador do Cantinho do Céu, } \\
\text { além de outros participantes que } \\
\text { moravam na região }\end{array}$ & $\begin{array}{l}\text { Atividade promovida pelo Sesc: Rios e Bairros } \\
\text { - mapeamento e passeio de barco pela } \\
\text { represa. }\end{array}$ \\
\hline 25 & 31/08/13 sáb & $\begin{array}{l}\text { Residência de Lucia e } \\
\text { Roseli - Rua Cairu - } \\
\text { Cantinho do Céu }\end{array}$ & Roseli, Lucia e Débora & $\begin{array}{l}\text { Conversa coletiva sobre andamento do } \\
\text { processo da interdição da casa de Débora. }\end{array}$ \\
\hline 26 & 21/09/13 sáb & $\begin{array}{l}\text { Residência de Eunice e } \\
\text { Carlos }\end{array}$ & Eunice e Carlos (nomes fictícios) & $\begin{array}{l}\text { Entrevista sobre a moradia no Lago Azul, o } \\
\text { processo de remoção e a mudança para o } \\
\text { Cantinho do Céu. }\end{array}$ \\
\hline 27 & 24/10/13 qui & $\begin{array}{l}\text { Associação de } \\
\text { moradores Cantinho do } \\
\text { Céu }\end{array}$ & $\begin{array}{l}\text { Renata e Sérgio - Mineral } \\
\text { Engenharia e Meio Ambiente / } \\
\text { Helena - Elevação }\end{array}$ & $\begin{array}{l}\text { Reunião da equipe da Mineral (empresa } \\
\text { contratada pela COMGÁS para ações de } \\
\text { compensação ambiental do gasoduto). Contato } \\
\text { com Helena, equipe de meio ambiente da } \\
\text { Elevação (empresa contratada da Sabesp para } \\
\text { ações de compensação ambiental das redes } \\
\text { de esgotamento da bacia do Cocaia). }\end{array}$ \\
\hline 28 & 24/10/13 qui & $\begin{array}{l}\text { Associação } r \text { de } \\
\text { moradores Cantinho do } \\
\text { Céu }\end{array}$ & $\begin{array}{l}\text { Sandro - presidente da associação } \\
\text { de moradores / Iris - professora do } \\
\text { MOVA }\end{array}$ & $\begin{array}{l}\text { Entrevista com Sandro sobre a ocupação do } \\
\text { bairro e atividades realizadas pela associação. }\end{array}$ \\
\hline
\end{tabular}




\begin{tabular}{|c|c|c|c|c|}
\hline 29 & 24/10/13 qui & CEU Dutra & $\begin{array}{l}\text { Audiência pública do Plano de } \\
\text { Requalificação do Transporte } \\
\text { Coletivo de SP - Região Sul } 2\end{array}$ & $\begin{array}{l}\text { Apresentação da proposta pela SPTrans e EIA- } \\
\text { RIMA pela Concremat. }\end{array}$ \\
\hline 30 & 28/10/13 seg & Residência Débora & $\begin{array}{l}\text { Débora - moradora do Cantinho do } \\
\text { Céu (sua casa está interditada pela } \\
\text { Defesa Civil) }\end{array}$ & $\begin{array}{l}\text { Entrevista sobre história de vida e situação de } \\
\text { moradia no bairro. }\end{array}$ \\
\hline 31 & $\begin{array}{l}17 / 12 / 13 \\
24 / 01 / 14\end{array}$ & $\begin{array}{l}\text { SEHAB } \\
\text { Martinelli }\end{array}$ & $\begin{array}{l}\text { Com Laís - mestranda da } \\
\text { antropologia }\end{array}$ & $\begin{array}{l}\text { Consulta ao Processo Administrativo relativo } \\
\text { ao Cantinho do Céu e Residencial dos Lagos }\end{array}$ \\
\hline 32 & $24 / 02 / 14$ seg & Parque do Lago Azul & $\begin{array}{l}\text { Vanilson FIFO - integrante do OCA } \\
-\quad \text { Organização } \quad \text { Comunitária } \\
\text { Alternativa }\end{array}$ & Conversa inicial para apresentação \\
\hline 33 & $\begin{array}{l}29 / 04-06 \text { e } \\
13 / 05 / 14 \text { ter }\end{array}$ & CEU Navegantes & Alunos do Ensino Médio & $\begin{array}{l}\text { Oficinas de mapeamento regional com alunos } \\
\text { da Escola Estadual Maria Luiza de Andrade } \\
\text { Martins Roque - Jd Eliana }\end{array}$ \\
\hline 34 & 06/08/14 qua & $\begin{array}{l}\text { Condomínio } \\
\text { Residencial Mata } \\
\text { Virgem }\end{array}$ & $\begin{array}{l}\text { Ana Lucia - síndica do Condomínio } \\
2 \text { do Residencial Mata Virgem }\end{array}$ & $\begin{array}{l}\text { Conversa inicial para estabelecimento de } \\
\text { contato com ex-morador do Cantinho do Céu }\end{array}$ \\
\hline 35 & 16/08/14 sáb & $\begin{array}{l}\text { Condomínio } \\
\text { Residencial Mata } \\
\text { Virgem }\end{array}$ & $\begin{array}{l}\text { Maria Lucilene - ex-moradora do } \\
\text { Lago Azul e atual moradora do } \\
\text { Residencial Mata Virgem - } \\
\text { Condomínio } 2\end{array}$ & Entrevista \\
\hline 36 & 18/09/14 qui & Fórum Helly Lopes & Processo judicial & $\begin{array}{l}\text { Consulta ao processo judicial aberto com Ação } \\
\text { Civil Pública pela Promotoria que provocou as } \\
\text { obras no Cantinho do Céu. }\end{array}$ \\
\hline 37 & 29/08/14 sex & $\begin{array}{l}\text { Jd Gaivotas - ONG } \\
\text { Vento em Popa }\end{array}$ & Oficina de cisterna & $\begin{array}{l}\text { Oficina de cisterna com reaproveitamento de } \\
\text { água da chuva }\end{array}$ \\
\hline 38 & $29 / 08 / 14$ sex & $\begin{array}{l}\text { Parque linear do Lago } \\
\text { Azul }\end{array}$ & $\begin{array}{l}\text { Tim e Fifo - OCA } \\
\text { Vinícius - administrador do parque } \\
\text { pela SVMA }\end{array}$ & $\begin{array}{l}\text { Sessão de vídeo sobre as APAS municipais } \\
\text { organizado pelo coletivo OCA }\end{array}$ \\
\hline 39 & 30/08/14 sáb & $\begin{array}{l}\text { Parque linear do Lago } \\
\text { Azul }\end{array}$ & Virada Sustentável & $\begin{array}{l}\text { Virada Sustentável com várias atividades } \\
\text { culturais organizadas por coletivos de cultura } \\
\text { da Zona Sul }\end{array}$ \\
\hline 40 & 30/08/14 sáb & $\begin{array}{l}\text { Nova residência de } \\
\text { Debora }\end{array}$ & Debora & Visita a nova moradia de Debora \\
\hline 41 & 06/09/14 sáb & Lago Azul & $\begin{array}{l}\text { Vinícius - administrador do parque } \\
\text { pela SVMA } \\
\text { Vera - candidata ao conselho }\end{array}$ & $\begin{array}{l}\text { Eleição Conselho Gestor do "Parque Cantinho } \\
\text { do Céu" }\end{array}$ \\
\hline 42 & 23/09/14 ter & $\begin{array}{l}\text { Residência de Seo } \\
\text { Pedro - Cantinho do } \\
\text { Céu }\end{array}$ & $\begin{array}{l}\text { Seo Pedro - morador do Cantinho } \\
\text { do Céu }\end{array}$ & $\begin{array}{l}\text { entrevista individual aberta com enfoque para } \\
\text { seus planos tendo em vista que está prevista a } \\
\text { remoção de sua casa. }\end{array}$ \\
\hline 43 & 23/09/14 ter & $\begin{array}{l}\text { Residência de Seo } \\
\text { João do Peixe }\end{array}$ & $\begin{array}{l}\text { Seo João do Peixe - morador antigo } \\
\text { do Cantinho do Céu }\end{array}$ & entrevista sobre o bairro e sua vida \\
\hline 44 & $24 / 10 / 14$ sex & $\begin{array}{l}\text { Residência de Seo } \\
\text { João do Peixe }\end{array}$ & $\begin{array}{l}\text { Seo João do Peixe - morador antigo } \\
\text { do Cantinho do Céu }\end{array}$ & entrevista sobre o bairro e sua vida \\
\hline 45 & 24/10/14 sex & $\begin{array}{l}\text { Rua } 9 \text { de setembro, Jd } \\
\text { Gaivotas }\end{array}$ & Teatro "À margem" da Cia Humbalada & \\
\hline 46 & 24/10/14 sex & Parque do Lago Azul & Tim e Fifo & $\begin{array}{l}\text { Entrevista sobre formação do coletivo OCA e } \\
\text { atividades culturais realizadas. }\end{array}$ \\
\hline
\end{tabular}





\section{APÊNDICE 2}

\section{PROCESSO JUDICIAL No. 0405292-44.1997.8.26.0053 (336/97) REFERENTE À Ação Civil Pública ajuizada pelo Ministério Público de São Paulo em fevereiro de 1997}

Uma fonte de dados primários relevante à reconstrução histórica da ocupação do bairro e como o Poder Público, em suas esferas Municipal e Estadual, tem enfrentado o parcelamento irregular do solo é Processo No. 0405292-44.1997.8.26.0053 (336/97) referente à Ação Civil Pública ajuizada pelo Ministério Público de São Paulo em fevereiro de 1997. O Processo, que até setembro de 2014 constava de um conjunto de 21 volumes, de aproximadamente 200 folhas cada, ainda está em trâmite na 4a .Vara de Fazenda Pública - Foro Central, no Fórum Hely Lopes Meirelles e fica à disposição para consulta no local, inclusive para cópias xerográficas e fotos, se necessário. O documento foi consultado nos meses de agosto e setembro de 2013 e setembro de $2014{ }^{1}$.

Elenco a seguir aspectos do Processo que chamaram a atenção, me valendo da consideração de que, mesmo com leitura atenta, não disponho de conhecimento técnico de muitos termos e procedimentos do Direito. Deixei em cor preta as informações referentes ao andamento do próprio processo judicial, em cor vermelha as informações constantes do Procedimento de averiguação No. 86/94, e em cor azul, do Procedimento de averiguação No. 49/95. Os Procedimentos tem um caráter de investigação, reunindo depoimentos, relatórios e laudos que subsidiaram a Ação Civil Pública instaurada.

Processo Judicial 336/1997 - 21 volumes até setembro de 2014

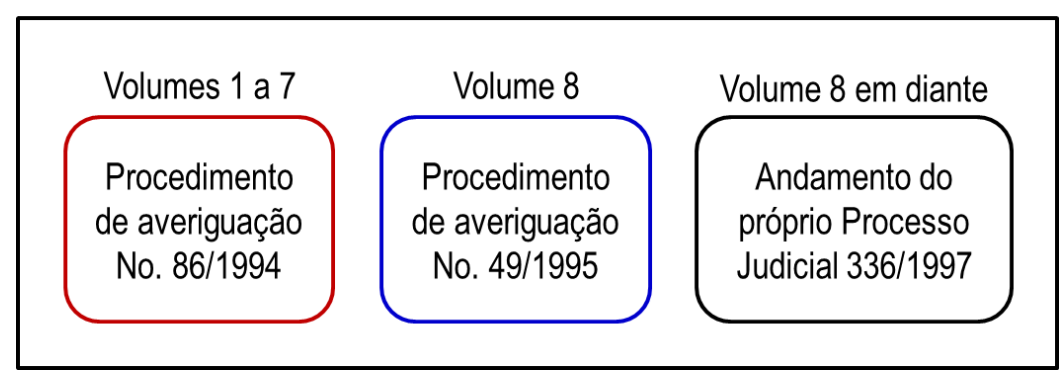

\section{--- início das transcrições --- Fl 01 a 201}

1. Processo aberto em 31/03/1997 com a Ação Civil Pública (ACP) do Promotor Carlos Alberto Amin Filho de fevereiro de 19972. A ACP cita - o que pode ser entendido como "acusa" - o Município de São Paulo, o Estado de São Paulo, Leonide Pedro Tatto e Enoque Leocádio dos Santos como responsáveis pelo parcelamento irregular do solo de duas glebas que compõem o

10 processo pode ser consultado também na página do Tribunal de Justiça do Estado de São Paulo no link Consultas Processuais. https://esaj.tisp.jus.br. Acesso em 09 dez 2014.

${ }^{2}$ A ACP está disponivel na internet http://www.apmp.com.br/juridico/pjhuc/pecas/peca4.htm. Acesso em 15 nov 2013. 
bairro Cantinho do Céu, pedindo Medida Liminar ao juiz e indicando "a adequação do loteamento às disposições legais vigentes que, em observância a critérios de conveniência e de oportunidade do Poder Público, poderão implicar na adaptação de sua conformação física ou no seu desfazimento (ainda que parcial)" sob pena de multa diária sugerida no valor de R\$ 10.000,00 aos Poderes Públicos e às pessoas físicas a pena de Improbidade Administrativa.

\section{Procedimento de averiguação No. 86/94 aberto em agosto de 1994}

2. Carta-denúncia anônima de 30 de julho de 1994, onde é relatado o processo de ocupação irregular no bairro Cantinho do Céu pedindo solução à Promotoria. O documento é assinado por "Moradores da região da represa Billings". Ver ANEXO 1.

3. DUSM envia ofício No. 128/94, em 12 de agosto de 1994, ao Promotor anexando Laudo Técnico com fotos sobre o loteamento Cantinho do Céu (Processo SMA No.101.676/94). O Laudo Técnico é realizado a partir de vistoria em 01/07/1994³ e relaciona a aprovação de parcelamento do solo existente, a qualificação da área conforme legislação incidente ( $1^{\mathrm{a}}$ categoria e $2^{a}$ categoria - classe C da LPM 75/76), os responsáveis pelos empreendimentos: Lago Azul Imóveis e Associação Comunitária Cantinho do Céu e os procedimentos legais e técnicos cabíveis para a regularização. Segundo o Laudo, "o loteamento apresenta uma parte mais antiga de $83.000 \mathrm{~m}^{2}$ aproximadamente, com um projeto original de lotes de 500,00 até $1.300,00 \mathrm{~m}^{2}$ e uma parte mais nova de $260.000 \mathrm{~m}^{2}$, sem projeto, com ocupação desordenada, com lotes de $125,00 \mathrm{~m}^{2}$ atingindo inclusive a faixa de 50 metros, faixa non aedificandi, que margeia a represa". Sendo o loteamento Chácaras Cantinho do Céu descaracterizado por reparcelamento.

4. Em 25 de agosto de 1994 Promotor solicita esclarecimentos sobre o parcelamento para Cestesb, $11^{\circ}$. Cartório, Delegacia, Resolo, Eletropaulo, Sabesp, CRECI e Secretaria de Estado da Habitação. Esses ofícios são reencaminhados em 19 de outubro de 1994.

5. Em 28 de outubro de 1994 o $11^{\circ}$ Cartório responde dizendo que não há loteamento inscrito com o nome Chácaras Cantinho do Céu conforme Decreto-lei 58/37 nem Lei 6.766/79; informa as transcrições com os nomes dos proprietários, dentre eles Klaus Kaschdailis e Barbel Kaschdailis, Luiz Dias Barreira, Light, Flávio Moyses Dotta, José Alexandre Passos Filho e Joana D’arc Lordello Passos.

6. Em 04 de novembro de 1994 Sabesp relata que em 1990 houve autorização para implantação de rede de água e que entre maio e outubro de 1993 foram implantados 24.000 metros lineares de rede de água. Em relação a redes de esgoto, são previstos estudos a serem iniciados em 1996 dentro do Programa de Despoluição do Rio Tietê.

7. Em 22 de dezembro de 1994 - Depoimento de Antonio Ivan Uchoa, cobrador de ônibus, quando relata a venda de lotes, o maquinário da família Tatto

8. Em 22 de dezembro de 1994 - Depoimento de Floripes Pereira de Andrade

9. Em 22 de dezembro de 1994 - Depoimento de Ivan e Floripes relatando que Arsênio Conde Gonzales pretende resolver a situação dos lotes com a escritura definitiva solicitando pagamento aos moradores.

\footnotetext{
3 Pela data da vistoria de campo, repara-se que a SMA estava fiscalizando a área e já havia deflagrado o processo de parcelamento irregular. Lança-se aqui o insumo contraditório ao discurso de que havia falta de fiscalização do Poder Público. Talvez, o que possamos inferir é a falta de encaminhamentos práticos e efetivos diante do processo de ocupação irregular deflagrado a partir das vistorias de campo, da fiscalização.
} 


\section{--- fim do $1^{\circ}$ volume - início $2^{\circ}$ volume --- Fl 202 a 402}

10. Em 04 de janeiro de 1995 depoimento de José Roberto de Souza Lima, motorista,

11. Depoimento de Arsenio Conde, comprou lote de 5.000m² em 1991 e se mudou em 1992.

12. Em 06 de março de 1995 Resolo informa sobre a impossibilidade de regularizar

13. Em 11 de fevereiro de 1995 depoimento de Klaus e Barbel, compraram em 1974, anexa Carta a Leonide de 25/09/92 onde pedem a desapropriação para creche ou escola, anexo também Vistoria do terreno pelo Resolo.

\section{--- fim do $2^{\circ}$ volume - início do $3^{\circ}$ volume --- $\mathrm{Fl} 404$ a 604}

14. Transcrições das glebas - desde 1894 - Firmino Antonio Silva vendeu para Serafim Pires de Moraes e Benta Maria de Moraes que vendeu em 1908 para Francisco José Gomes, sendo escriturada a venda em 1921. Parte da gleba (aprox.. 7,5 alqueires) foi vendida à Light em 1926.

15. Em 20 de junho de 1995 CETESB a partir de vistoria de campo, informa ao Promotor diretrizes para a regularização mas “o empreendimento dificilmente será licencidado por esta Cia, ainda que sob forma de regularização devido a ocupação desordenada, atingindo inclusive a faixa de 50 metros que margeia a represa e a falta total de infraestrutura"

16. Em 27 de junho de 1995 Resolo informa que procederá a regularização do loteamento conforme Lei Municipal 11.775/95 e com licenciamento nos órgãos estaduais já que se encontra em área de mananciais.

17. Em 12 de junho de 1995 Secretaria Municipal de Finanças informa que apenas há lançamento de IPTU no Chácara Gaivotas, desde 1982.

18. Em 13 de julho de 1995 Sabesp informa que quando instalaram as redes no Gaivotas, Parque Residencial Cocaia e Cantinho do Céu os loteamentos já estavam instalados e que por isso não vê a atitude da Sabesp como "contribuinte de forma dolosa para a implantação de uma habitacional"

19. Em 14 de agosto de 1995 depoimento de Leo Augusto Pinto e Cecília Guine onde relatam que a “área era um verdadeiro paraíso ecológico, sendo habitada, principalmente, por europeus fugidos da guerra (uma vez que o loteamento Cantinho do Céu fora implantado em 1943); naquele tempo só se poderia chegar à área de barco; tal situação perdurou até o ano de 1988, em tal época, estimulados pela então prefeita Luiza Erundina, chegaram à área inúmeros invasores...”. Ver ANEXO 2.

20. Em 18 de julho de 1995 Incra informa que não houve "nenhum pedido de alteração de uso de solo rural para fins de parcelamento urbano referentes ao loteamento "Cantinho do Céu, Gaivotas, Parque Residencial Cocaia e Lago Azul”

\section{--- fim do $3^{\circ}$ volume - início do $4^{\circ}$ volume --- Fl 606 a 806}

21. Em 25 de agosto de 1995 Parsolo/SEHAB envia o Auto de Regularização do Chácara Gaivotas, de 29/11/79, área de $171.428,20 \mathrm{~m}^{2}$, Z8-100, proprietária Jaima Rocha Alchueyd.

22. Em 19 de setembro de 1995 são enviadas cópias do inquérito policial 68/94 da Polícia Civil/3a Delegacia de Polícia de Meio Ambiente. Constam depoimentos de Antonio Ivan Uchoa, Floripes Pereira de Andrade, José Zacarias Alves de Souza - proprietário imobiliária Bahia, Orlando David Filho - que teve seu registro do CRECI utilizado para vendas dos lotes, Enoque Leocádio dos Santos , Arselino Roque Tatto e Leonide Pedro Tatto; ofício de Suely - renúncia da advogada pelo inventário de José Francisco Gomes; Relatório informando propriedade de 
Irmãos Angélico Ltda. em comodato para Domiciano da Silva Oliveira cuja área foi invadida em 1990.

23. Em 09 de outubro de 1995 Telesp informa que a "prestação individualizada do serviço telefônico é feita a quem solicite".

24. Em 01 de setembro de 1995 Secretaria de Finanças informa que as irregularidades dos loteamentos estão sendo encaminhados pelo Resolo através dos processos: Cantinho do Céu Invasão - Processos 05-006.485/90*67 e 05-015.652/90*98; Cantinho do Céu Chácaras -

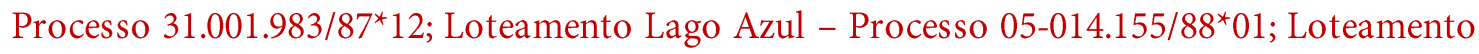
Residencial Cocaia e Parque Recanto Cocaia - Processo 05-003.436/85^88. Há cópias do trâmite na PMSP com indicações dos números dos processos administrativos de regularização de loteamentos lindeiros como Sítio dos Pereiras, Residencial Sipramar, Jd Erundina entre outros.

25. Em 02 de agosto de1995 Administração Regional envia Autos de multa e interdição aplicados à Associação Comunitária Cantinho do Céu, referente a área loteada de $343.000 \mathrm{~m}^{2}$ no dia 06/07/1995.

26. Em 06 de outubro de 1995 Sabesp informa 3000 ligações de água na Península com datas de ligação do Lagos em 16/11/93; Recanto Cocaia em 5/7/94; Cantinho do Céu em 2/8/94 e Gaivotas em 3/8/94.

--- fim do $4^{\circ}$ volume - início do $5^{\circ}$ volume --- Fl 809 a 1008

27. Contas de água anexadas no ofício da Sabesp.

\section{--- fim do $5^{\circ}$ volume - início do $6^{\circ}$ volume --- Fl 1011 a 1208}

28. Em 20 de novembro de 1995 Leonide Tatto informando que quando assumiu a Administração Regional o Cantinho do Céu já era habitado por centenas de famílias e que atendendo a solicitações mandou cascalhar as ruas principais afim de que o lixo pudesse ser coletado.

29. Em 06 de dezembro de 1995 Resolo/SEHAB informa que é possível regularizar à luz da lei municipal 11.775/95 e que será solicitada anuência do Estado, entende que o "desfazimento do loteamento se torna impossível tendo em vista a existência comprovada de 250.00 lotes já implantados, edificados e habitados".

30. Em 28 de dezembro de 1995 Enoque Leocádio envia Relatório sobre Proteção dos Mananciais.

31. Em 01 de janeiro de 1996 Arsenio Gonzales relata que a Associação de Moradores está vendendo lotes, iludindo os moradores pois está prometendo a escritura. Informa que o local está em litígio por ser de propriedade do espólio de Francisco José Gomes e Filisbina Maria das Dores que está em curso.

\section{--- fim do $6^{\circ}$ volume - início do $7^{\circ}$ volume --- Fl 1213 a 1399}

32. Em 25 de abril de 1996 DUSM/SMA envia lista da situação dos loteamentos onde diz que todos os projetos pré-existentes à LPM foram descaracterizados, ocorrendo reparcelamento dos lotes e que a Península do Cocaia está $80 \%$ ocupada. Anexos fotos aéreas e mapas.

33. Cópias de multas e embargos da Secretaria de Negócios Metropolitanos: multa em 10/03/89 a Portal Imóveis e Empreendimentos pelo Condomínio Lago Azul; multa em 08/03/89 a Portal Imóveis e Empreendimentos pelo Condomínio Lago Dourado; embargo em 18/12/91 José Pereira da Silva pelo Sitio dos Pereiras; multas em 1988/1986/1993 pelo Pq Cocaia. 
34. Em 12 de agosto de 1996 DUSM/SMA informa que não é possível regularizar o loteamento Cantinho do Céu pela Lei vigente visto que foi implantado "frontalmente em desacordo com a Legislação de Proteção aos Mananciais”.

35. Em 19 de outubro de 1996 - Levantamento do Ministério Público referente a outros Procedimentos de investigação de loteamentos lindeiros em área de proteção de mananciais.

Fim do Procedimento de averiguação No. 86/94

\section{Procedimento de averiguação No. 49/95 sobre Pq dos Eucaliptos}

36. Em 24 de janeiro de 1990 Secretaria de Habitação e Desenvolvimento Urbano do Estado de SP pede à Procuradoria do Estado a apuração das responsabilidades do Pq dos Eucaliptos sob responsabilidade da empresa J. M. Brito.

37. Cópia de auto de infração da Secretaria de Negócios Metropolitanos de 01 de junho de 1989 referente à área invadida sem licença - Pq dos Eucaliptos aplicada a J. M. Brito Construções e Empreendimentos Imobiliários Ltda.

38. Cópia de auto de embargo de obra da Secretaria de Negócios Metropolitanos de 13 de dezembro de 1989 referente a implantação de loteamento com movimento de terra, remoção de cobertura vegetal em APM sem prévia autorização da Secretaria (área invadida) aplicada a J. M. Brito Construções e Empreendimentos Imobiliários Ltda.

39. Cópia de auto de multa diária no valor de 1.673,26 cruzados novos da Secretaria de Negócios Metropolitanos de 13 de dezembro de 1989 referente a implantação de loteamento com movimento de terra, remoção de cobertura vegetal em APM sem prévia autorização da Secretaria (área invadida) aplicada a J. M. Brito Construções e Empreendimentos Imobiliários Ltda.

40. Cópia de Laudo da SHDU (vistoria em 16/08/89) onde consta que “a área foi invadida há aproximadamente 2 anos e os lotes estão sendo vendidos pelos próprios moradores; a empresa J.M. Brito Ltda. solicitou à SHDU/Emplasa duas Análises de Orientação (no. 0759/80 e 0722/87) referente à área em questão; a implantação do loteamento se deu sem a prévia aprovação da SHDU, conforme prevê o Art. $3^{\circ}$. da Lei 898/75".

\section{--- fim do $7^{\circ}$ volume - início do $8^{\circ}$ volume --- Fl 1400 a 1615}

41. Cópia da Análise de Orientação No. 0722/87, de 02 de setembro de 1987 - área total de $794.798,00 \mathrm{~m}^{2}$, lotes de $5.000 \mathrm{~m}^{2}$ permitidos configurando um total máximo de 148 lotes.

42. Cópia da Análise de Orientação No. 0759/80, de 31 de outubro de 1980 - área total de $794.798,00 \mathrm{~m}^{2}$, lotes de $5.000 \mathrm{~m}^{2}$ permitidos configurando um total máximo de 148 lotes.

43. Cópias de matrículas de glebas onde consta que várias áreas foram hipotecadas em junho de 1980 e arrematadas em 1992 pela Caixa Econômica do Estado de SP.

44. Em 24 de setembro de 1992 Termos de Declaração de Divino Soares, advogado, e Cleide Nery de Brito onde consta que Juracy, marido de Cleide, morreu em 1981 e apesar de terem protocolado diretrizes na Emplasa em 1980, não tiveram interesse em empreender dado o número de lotes permitido. Dizem não conhecer o nome e endereço de quem protocolou documento em 1987 em nome da empresa.

45. Em 23 de março de 1995 Promotor pedelaudos técnicos em relação ao Parque dos Eucaliptos à CETESB, SOS Mananciais, Secretaria da Habitação do Estado, Administração Regional Capela do Socorro, 2a . Delegacia de Defesa Comunitária e Fundiária. 
46. Em 03 de abril de 1995 Secretaria da Habitação do Estado informa que não há Anuência Prévia para Parque dos Eucaliptos e que de acordo com as Leis 30.555 de 03/10/89 e 33.407 de 24/06/91, a competência é da Secretaria de Meio Ambiente do Estado.

47. Em 07 de junho de 1995 SOS Mananciais informa que não localizou a área.

48. Em 09 de junho de 1995 CETESB solicita mais informações para localizar o registro em seus arquivos.

49. Em 02 de dezembro de 1996 Resolo envia Laudo de 27/11/96 do Parque dos Eucaliptos, onde consta área de $794.798 \mathrm{~m}^{2}, 5.000 \mathrm{~m}^{2}$ área do lote permitido constando lotes de 75 a $12 \mathrm{~m}^{2}$, zoneamento Z15-005. O Ofício informa que o MP já está investigando a área no Procedimento $86 / 94$.

50. Em 04 de dezembro de 1996 CETESB informa que nada consta em nome de Parque dos Eucaliptos e que para regularizar é necessário ter coleta de lixo e rede de esgoto.

51. Em 23 de dezembro de 1996 DUSM envia laudo técnico do Parque dos Eucaliptos

Fim do Procedimento de averiguação No. 49/95

\section{--- fim do $8^{\circ}$ volume - início do $9^{\circ}$ volume --- Fl 1616 a 1816}

52. Em 28 de abril de 1997 Manifestação contrária do Estado referente ao Pedido de Liminar para que "Município e Estado providenciem a desocupação das áreas de risco (a serem delimitadas por seus órgãos) e das inseridas em $1^{\text {a }}$. Categoria, providenciando a prévia transferência dos moradores para abrigos provisórios".

53. Em 09 de maio de 1997 juiz Carlos Bortoletto Schimitt Correa defere Liminar parcial para desocupar áreas de risco e de $1^{\text {a }}$. Categoria com prazo de 180 dias sob pena de multa diária no valor de $\mathrm{R} \$ 2.000,00$.

54. Em 13 de maio de 1997 Mandados de notificação ao Município e Estado para desocupar as áreas de risco e próximas a nascentes e cursos d'água.

55. Em 13 de junho de 1997 Estado apresenta Contestação da Liminar ao juiz.

56. Em 01 de julho de 1997 Município apresenta Agravo de Instrumento ao juiz.

\section{--- fim do $9^{\circ}$ volume - início do $10^{\circ}$ volume --- Fl 1817 a 1994}

57. Em 06 de fevereiro de 1998 Estado envia Laudo de áreas de risco elaborado pelo DUSM em setembro e outubro de 1997 referente ao Parque dos Eucaliptos e Cantinho do Céu, contabilizam 386 edificações em áreas de risco. Esse Laudo, que inclui outros bairros da Península do Cocaia, mapeia o que seria ocupação até 1976 e até 1994.

58. Em 06 de abril de 1998 Promotor envia notícia de jornal de 27 de março de 1998 e cópia da nova Lei de Mananciais.

59. Em 02 de abril de 1998 Estado envia Plano de Demolição indicando a necessidade de articulação para além da Secretaria de Meio Ambiente do Estado, envolvendo: Prefeitura para remoção com cadastramento das famílias, Eletropaulo para corte de energia na área removida, Polícia Militar para garantir integridade física e moral dos agentes públicos envolvidos, Secretaria da Fazenda para fiscalizar atividades irregulares como comércio de materiais de construção e Sabesp para corte de fornecimento de água.

--- fim do $10^{\circ}$ volume - início do $11^{\circ}$ volume --- Fl 2000 a 2214 
60. Em 25 de fevereiro de 1998 Cópias de ofícios da CPRN à Sabesp, CPOS, Eletropaulo, DAEE pedindo colaboração para proceder com a remoção.

--- fim do $11^{\circ}$ volume - início do $12^{\circ}$ volume --- Fl 2215 a 2417

61. Em 10 de novembro de 1998 Município solicita ao juiz mandado de desocupação independente do Estado.

62. Em 11 de novembro de 1998 Juiz Fernão Borba Franco emite Mandado de Desocupação e Demolição de casas em áreas de risco do Cantinho do Céu.

63. Em 02 de dezembro de 1998 Município solicita ao juiz mobilização da tropa de choque.

64. Projeto Billings Legal

65. Levantamento de risco geotécnico da Sehab com cadastro das famílias e croquis de localização. Novo número: 46 casos em área de risco.

--- fim do $12^{\circ}$ volume - início do $13^{\circ}$ volume --- Fl 2419 a 2616

66. 1998 - Carta de Klaus e Bárbara ao Promotor, propõem a desapropriação da Chácara onde moram.

67. Em 01 de fevereiro de 1999 juiz Fernão Borba Franco derruba a Liminar de 1997.

68. Em 19 de março de 1999 promotor contesta juiz.

69. Apenso Agravo do Município de 27/06/97.

70. Apenso Agravo do Promotor.

71. Apenso Agravo do Estado de 17/11/98.

--- fim do $13^{\circ}$ volume - início do $14^{\circ}$ volume --- Fl 2617 a 2800

72. Ata de reunião de 15/05/02 entre Promotoria, SEHAB e DUSM. Fica acordado que os técnicos apresentarão Estudo Urbanístico e Estudo de risco incidente nas áreas. Ricardo Sampaio é o técnico do Programa Alto Tietê da Sehab, Ana Lucia Ancona é coordenadora do Programa Alto Tietê e Claudio Bolzani diretor do DUSM.

73. Em 23/10/02 apresentação de proposta de regularização da área com: Plano de Esgotamento da Sabesp (3 EEE no Residencial dos Lagos, 8 no Cantinho e 4 no Gaivotas), Plano Emergencial da LPM de 1998 que incluiu o Cantinho, Plano Emergencial de abril de 2000 de Marcos Carrilho. Previstas 1785 remoções no total com mapeamento das áreas de $1^{\text {a }}$. categoria.

--- fim do $14^{\circ}$ volume - início do $15^{\circ}$ volume --- Fl 2801 a 2990

74. Continuação da proposta de regularização: relatório geotécnico da JNS-Hagaplan - contrato Sehab 002/2001. Atualização do cadastro das 46 unidades em risco.

75. Em 09/12/2002 despacho da prefeitura ao juiz falando sobre os projetos na tentativa de aliviar a culpa da ação.

76. Em 25/04/2003 promotor Amin anexa Relatório de áreas de risco do IPT, de abril de 2003, e reitera quePrefeitura e Governo do Estado não estão interessados na solução do conflito, pede o julgamento com a condenação dos requeridos.

--- fim do $15^{\circ}$ volume - início do $16^{\circ}$ volume --- Fl 2993 a 3222

77. Audiência em 14/04/04, Leonide não comparece, última participação do Promotor Amim. 
78. 30/06/04 - SMA, através da CPRN informa que vão priorizar outras áreas já que a Sabesp realizou esgotamento, o risco não é tão alto e as casas são de padrão superior a outras encontradas em outros bairros.

79. Entre 2005 e 2007 suspensões sucessivas do andamento processual solicitadas pelo Promotor JC Freitas.

80. Março/2007 - Desmembramento dos autos em relação a Leonide e Enoque.

81. 15/06/07 - Audiência com PMSP - Elisabete França, JNS-HagaPlan e Ricardo Sampaio Apresentação do Relatório de Diagnóstico da JNS realizado em janeiro/2007

--- fim do $16^{\circ}$ volume - início do $17^{\circ}$ volume --- Fl 3223 a 3408

82. Em 16/08/07 Ofício da SEHAB sobre ação integrada.

83. Em 26/10/07 cartório informa que Fazenda do Estado de São Paulo é titular das transcrições 12.329 de 23/04/1934 e No. 27.352 de 14/12/1998.

\section{--- fim do $17^{\circ}$ volume - início do $18^{\circ}$ volume --- Fl 3533 a 3821}

84. 03/12/07 - $11^{\circ} \mathrm{CRI}$ informa a Promotoria sobre os atuais proprietários registrados em cartório com cópias das matrículas.

85. 27/06/08 - PMSP envia Projeto Básico completo informando que as obras foram licitadas e serão contratadas em breve. Previstas 2.483 remoções.

--- fim do $18^{\circ}$ volume - início do $19^{\circ}$ volume --- Fl 3831 a 3999

86. 22/08/08 - Documentação sobre ação reintegração de posse, de 1991, de Irmãos Angelico contra Demétrio Rodrigues Freire e mais sete pessoas com Certidão de Objeto e Pé e cópias dos autos do referido processo no. 583.02.1991.163868-2/000000-000 que se encontra arquivado.

87. 01/10/08 - Sabesp informa que há mais de 6.250 ligações de água e que as redes de esgoto estão sendo executadas.

--- fim do $19^{\circ}$ volume - início do $20^{\circ}$ volume --- Fl 4000 a 4199

88. 02/06/09 - Ofício da Eletropaulo informando que a regularização se iniciou em 1998 através do Programa Luz e Cidadania

89. 10/03/10 - PMSP envia fotos da obra

90. 21/06/11 - GESP informa que as obras já foram iniciadas e tendo em vista a lei, o PRIS está sendo providenciado. Prazo final para obras em dezembro de 2012.

\section{--- fim do $20^{\circ}$ volume - início do $21^{\circ}$ volume --- a partir de Fl 4200}

91. 10/08/12 - Relatório do Programa Mananciais com fotos do parque, plantas do projeto de urbanismo, paisagismo, drenagem e pavimentação, informando Etapa 1 como concluída.

92. 10/09/12 - Ofício do Promotor José Carlos de Freitas ao juiz solicitando a formalização do acordo para que o processo judicial não atue como "mero instrumento de acompanhamento da regularização"

93. 19/10/12 - Abaixo-assinado de moradores do Cantinho do Céu solicitando pavimentação de algumas ruas e audiência pública com os moradores envolvidos.

94. 26/12/12 - Ofício do GESP solicitando então a elaboração da minuta colocando como prazo final dezembro de 2015 . 
95. 26/12/12 - Ofício da PMSP solicita a elaboração da minuta com o prazo final para dezembro de 2017.

96. Em 03/07/2013 o 1 Promotor de Justiça de Habitação e Urbanismo da Capital, José Carlos de Freitas, pede sentença do processo, condenando Estado e Município, adotando o cronograma de Fl 4384 e seu prazo final para a regularização completa do loteamento clandestino (fundiária, ambiental, urbanística), até 2017, à juíza Celina Kiyomi Toyoshima. Segundo o cronograma (Fl 4384), de acordo com a Fase III do Programa Mananciais, a execução do contrato é de 36 meses, tendo iniciado em 01/11/2012.

1. Projetos (PMSP) - até $08 / 2013$

2. Aprovações (GESP) - de 04 a 12/2013

3. Obras (PMSP) - de $11 / 2012$ a 04/2015

4. Elaboração de LEPAC (PMSP) - 05/2015 a 05/2016

5. Pesquisa de titularidades (PMSP) - 11/2012 a 12/2014

6. Aprovação do parcelamento (PMSP e GESP) - 01/2016 a 06/2017

7. Anuência do GESP-11/2016 a 08/2017

8. Registro do LEPAC em cartório - 04 a 10/2017

9. Entrega de títulos - 10 a 12/2017

97. 26/08/13 - GESP solicita "não condenação" do Estado.

98. 30/08/13 - PMSP solicita prazo de 60 dias para proceder ajustes no TAC e no cronograma proposto.

99. 07/01/14 - PMSP envia novo cronograma estendendo prazo final para dezembro de 2022.

100. 04/02/14 - Promotor solicita acordo para prazo final em dezembro de 2018 e anexa Minuta do TAC sob pena de multa diária de $\mathrm{R} \$ 10.000,00$.

101. 14/04/14 - PMSP solicita prazo de 60 dias para se manifestar.

102. 25/08/14 - Juíza Celina Kiyomi Toyoshima suspende o processo por 90 dias conforme requerido por Promotor para "discussão dos elementos do acordo com os ilustres representantes do Estado e do Município”.

--- fim das transcrições --- 



\section{APÊNDICE 3}

\section{Oficina de Mapeamento com alunos da Ee Maria Luiza realizada em abril e maio de 2014}

O objetivo de realizar uma oficina de mapeamento estava presente desde o projeto de pesquisa, no início do mestrado. A priori não existia a definição de uma faixa etária específica, o objetivo era mapear os lugares de modo colaborativo junto aos vivenciadores de várias idades e então, a partir desse material, elaborar uma leitura de paisagem e tecer algumas análises. No entanto, assim que as atividades de campo iniciaram-se, foi percebido que seria muito difícil realizá-la a partir da organização do próprio campo, ou seja, a partir da organização dos entrevistados em grupos. Busquei, então, apoio junto ao CEU Navegantes, cujo contato Marcelo Sena, coordenador educacional, se mostrou muito interessado e disposto a auxiliar na concretização da atividade. Por fim, a oficina contemplou alunos da Escola Estadual Maria Luiza, com quem a EMEF Jardim Eliana trabalha conjuntamente, utilizando a estrutura física do CEU no primeiro semestre de 2014.

Apresentei uma proposta de atividades cujo conteúdo acabou sendo adaptado in loco. Essas alterações foram decorrentes da adesão dos alunos à atividade, uma vez que a oficina consistia em apenas três dias de atividade, além da própria discussão levantada pelos participantes.

Os alunos da EE Maria Luiza estudavam no período noturno e tinham em sua maioria $15 \mathrm{e}$ 16 anos, alguns já se conheciam e eram amigos. A oficina fora planejada para o período vespertino, e nessa condição, quem participou era porque tinha disponibilidade de tempo. No primeiro dia havia dezessete participantes, no segundo, sete e no terceiro e último dia de oficina havia cinco.

Constam assim no presente Apêndice 3:

Proposta de oficina entregue à Coordenação Educacional do CEU em março de 2014;

Oficina 1 - Notas descritivas em relação à discussão gerada, imagens;

Oficina 2 - Notas descritivas em relação à discussão gerada e slides apresentados;

Oficina 3 - Notas descritivas em relação à discussão gerada e slides apresentados. 


\section{Proposta de Oficina ao CeU Navegantes a Ser desenvolvida no 1ํ Semestre de 2014}

Título:

Propontente voluntária:

Objetivos:

Justific ativa:

Métodos:

Público-alvo:

Espaço-físico e recursos necessários:
Mapas de vivência

Melissa Kikumi Matsunaga Arquiteta e urbanista, mestranda do Programa de Pós-graduação da Faculdade de Arquitetura e Urbanismo da Universidade de São Paulo, área de concentração Paisagem e Ambiente. Integrante do Núcleo de Estudos da Paisagem (NEP) do Laboratório Espaço Público e Direito à Cidade (LabCidade). Currículo Lattes: http://lattes.cnpq.br/9003470341774807

O objetivo da oficina é promover a leitura territorial do bairro a partir de seus vivenciadores.

A presente proposta contribui para pesquisa de mestrado em andamento na Faculdade de Arquitetura e Urbanismo da Universidade de São Paulo, iniciada em 2012, cujo objetivo é analisar a transformação da paisagem do Núcleo Cantinho do Céu. Parte-se, portanto, do olhar dos próprios moradores em relação ao desenvolvimento do bairro, desde seu histórico de ocupação até recentes intervenções urbanas promovidas pelo Poder Público.

Nesse sentido, a percepção e valoração do local de vivência por quem o habita é de extrema importância. A oficina busca não apenas contribuir para a pesquisa de mestrado em andamento, como também para a sensibilização e a constituição do envolvimento dos jovens diante das transformações urbanas em curso no bairro. Busca-se, para isso, identificações com o modo de vida e suas implicações sociais e ambientais no cotidiano.

O envolvimento dos jovens coloca a possibilidade de aprofundamento diante das questões já vivenciadas e sua inserção em relação a novas aberturas sociais e ambientais.

A partir do desenho livre, mapear de forma colaborativa o bairro: os percursos cotidianos, os pontos de referência de atividades significativas (morar, estudar, lazer). Ver Plano da Oficina anexo.

Jovens que participam das atividades do CEU com idade entre 13 e 17 anos. Máximo de 15 participantes.

- Sala de aula com mesas para trabalho em grupo

- Datashow (3 dia da oficina)

- 15 lápis grafite 2B / borrachas

- 15 jogos de lápis de cor

- 15 jogos de canetas hidrográficas

- papel sulfite A2

- papel pardo

- fita adesiva

- barbante 


\section{Plano da Oficina Mapas de Vivência}

A oficina é constituída de três encontros de 2h30h de duração aproximadamente, conforme sugestão de datas a seguir:

10 encontro (2h30), dia 22/04/2014, terça-feira

\begin{tabular}{|l|l|}
\hline Apresentação & $\begin{array}{l}\text { - Apresentação da proponente } \\
\text { - Apresentação dos participantes } \\
\text { - Introdução com apresentação do plano da oficina } \\
\text { - Breve discussão sobre o bairro }\end{array}$ \\
\hline $\begin{array}{l}\text { Parte 1: Desenho livre } \\
\text { individual }\end{array}$ & $\begin{array}{l}\text { - Desenho de memória: desenho livre que represente aspecto } \\
\text { significativo do bairro a partir do que se entende por: Cantinho do Céu } \\
\text { - Apresentação dos desenhos para o grupo }\end{array}$ \\
\hline $\begin{array}{l}\text { Intervalo } \\
\text { coletivo }\end{array}$ & $\begin{array}{l}\text { - Divisão em grupos de no máximo 4 participantes } \\
\text { - Mapeamento afetivo do bairro: percursos cotidianos, local de moradia, } \\
\text { local de estudos, local de lazer, local de comércio, fluxo de carros, local } \\
\text { de feira, local onde se sente bem, onde se sente mal, com medo ou } \\
\text { perigo, locais especiais por algum motivo) }\end{array}$ \\
\hline
\end{tabular}

20 encontro (3h), dia 29/04/2014 terça-feira

\begin{tabular}{|l|l|}
\hline Parte 1: Passeio Sensível & $\begin{array}{l}\text { - Divisão em grupos sensíveis (visão, audição, tato, olfato, fala) } \\
\text { - Passeio pela quadra, cada grupo enfocando um sentido específico. } \\
\text { Entrevistar uma pessoa que encontrar no percurso. }\end{array}$ \\
& $\begin{array}{l}\text { - Apresentação de cada grupo seguida de discussão sobre o passeio } \\
\text { sensível }\end{array}$ \\
\hline $\begin{array}{l}\text { Intervalo } \\
\text { coletivo } 2: \text { Mapeamento }\end{array}$ & $\begin{array}{l}\text { - Divisão em grupos } \\
\text { - A partir de mapa-base a ser fornecido (com arruamento e nome das } \\
\text { ruas) identificação dos pontos "sensíveis" significativos, retomando } \\
\text { encontro anterior (local de moradia e demais usos, percursos realizados } \\
\text { no passeio, local da entrevista) }\end{array}$ \\
\hline
\end{tabular}

3o encontro (2h30), dia 06/05/2014 terça-feira

\begin{tabular}{|l|l|}
\hline $\begin{array}{l}\text { Parte 1: Apresentação com } \\
\text { datashow }\end{array}$ & $\begin{array}{l}\text { - Apresentação de aspectos históricos da área de mananciais (represa } \\
\text { Billings e crescimento da cidade) }\end{array}$ \\
\hline $\begin{array}{l}\text { Intervalo } \\
\text { coletivo }\end{array}$ & $\begin{array}{l}\text { Mapeamento } \\
\text { - Metomada dos grupos formados no encontro anterior } \\
\text { ingreme), sem pavimentação, com pavimentação, com despejo } \\
\text { inadequado de lixo ou entulho, mato. }\end{array}$ \\
\hline Fechamento ambiental: locais com arborização, córregos e nascentes, \\
\hline
\end{tabular}




\section{OFICINA 1 - REALIZADA DIA 29/04/2014, TERÇA-FEIRA, Às 14 H30}

O primeiro dia de oficina contou com dezessete participantes, apenas um correspondia ao sexo masculino. Apresentei-me de início e logo em seguida pedi para que se apresentassem, falando a idade, com quem moravam, em que bairro e desde quando. A maior parte respondeu que morava com a família desde que nasceram, a idade era de 15, 16 anos predominantemente e cursavam em sua maioria o $2^{\circ}$ ano do Ensino Médio no período noturno.

No segundo momento da atividade solicitei que desenhassem ou escrevessem sobre o bairro em que moravam. Os desenhos elucidaram aspectos do cotidiano, os percursos realizados e pontos de referência dos bairros. Um dos aspectos que me chamou a atenção foi a não representação da represa, ou seja, a ausência da represa no cotidiano deles. Os textos tinham maior riqueza de elementos a serem discutidos, indicando inclusive sentimentos de não aceitação ou desprezo pelo bairro em que moravam, principalmente pelo fato dos moradores não se respeitarem, ou por haver roubos diariamente. Por outro lado, a vida em família estabelecia o laço afetivo ao bairro. Solicitei a cada um que explanasse sobre sua produção, e na maioria dos relatos a existência da família e dos amigos vinculavam o lugar ao sentimento de pertença. Ao mesmo tempo que "as pessoas destroem" ou "não cuidam" era vinculado a um contexto de precariedade de infraestrutura, como esgoto e lixo nas ruas.
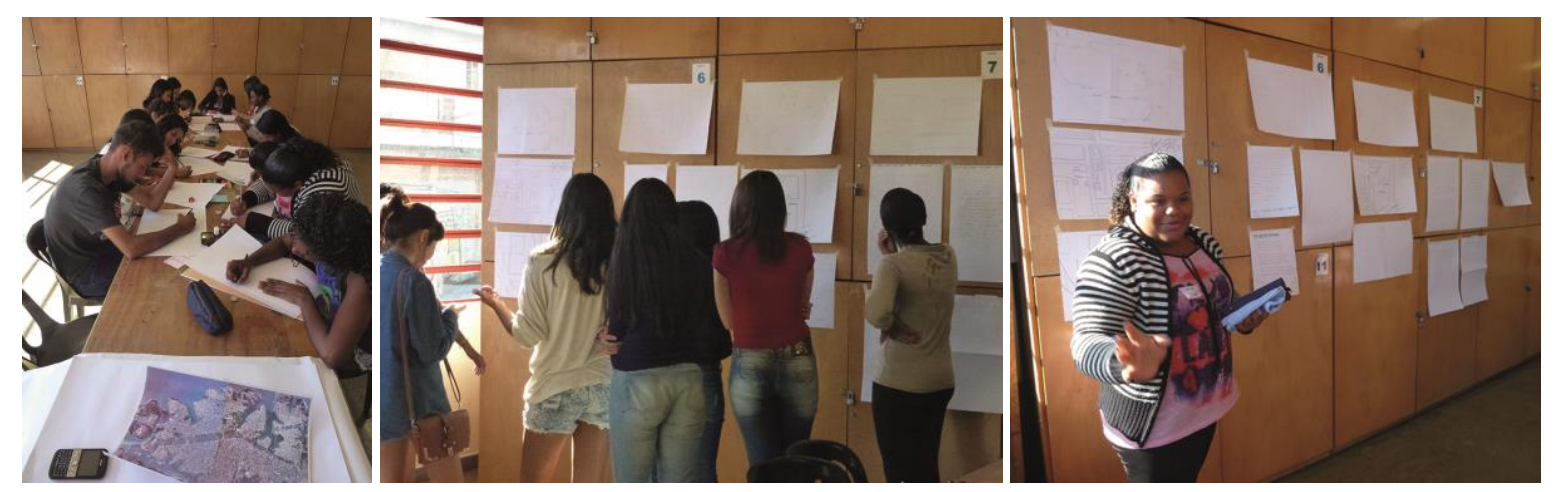

Transcrição dos textos elaborados pelos alunos da EE Maria Luiza neste dia:

"Bom, na parte onde moro é onde tiraram muitas casa (mas a minha não saiu). Pois eles tiraram as casas em promessa que fossem fazer uma área de lazer para os moradores. Eles começaram a obra quando foi no final do ano passado eles pararam com a obra e logicamente não fizeram nada como o comprometido. Realmente eu não gosto desse lugar (Cantinho do Céu), ele é muito perigoso e as pessoas não sabem respeitar ninguém nesse lugar. E o único lazer que temos é o Lago Azul, mas tambémé uma caminhada do Cantinho atéo Lago Azul. Nem todas as ruas são asfaltadas aqui, esse lugar é um caso sério, a prefeitura só promete as coisas e nunca cumpre." - mora no Cantinho do Céu com pais e dois primos, 16 anos. 
"Bom moro aqui no Cantinho do Céu desde quando nasci, minha casa foi inaugurada praticamente comigo, antes meus familiares moravam todos juntos e tals. Embora eu tenha passado minha vida inteira aqui, eu não acho que aqui seja um bom lugar para se morar, tem lá seus lados positivos, mas não é um lugar adequado para morar não, na minha opinião, claro. Os moradores mesmo estragam o local em que moramos. Cocaia, Cantinho do Céu já não é bem falado, aí as pessoas ainda ajuda, aí fica difícil... Aqui abre comércios em cima de comércios, que é o melhor para nós claro, mas os que se dizem bandidinhos mesmo roubam a Quebrada. A prefeitura começa as obras e nunca termina, a maioria das ruas são asfaltadas menos minha rua, e foi prometido que seria feito depois que arrumassem as encanações. Bom, isso foi feito ano passado, e cadê o asfalto da minha rua, estamos no aguardo... Quando me perguntam como é o bairro que eu moro, eu chego a dar risada, todos os lugares tem roubo, mas aqui só pela misericórdia, é roubo quase todos os dias, quase nunca temos paz, quase nunca a gente pode dizer que aqui tá tranquilo. Ninguém se respeita, ninguém respeita o espaço aqui. Polícia tem sempre, mas nunca resolvem. O que me mantem aqui no Cantinho do Céu são meus pais, minha idade também não permite que eu saia de casa, amigos, namorado, familiares, mas não indicaria Cantinho do Céu um bom lugar para se morar." - mora com mãe, padrasto e quatro irmãos no Cantinho do Céu, 16 anos.

$---$

"Como faz pouco tempo que eu moro no Eliana, não tenho muito o que falar, mas assim pelo fato de ser um bairro menor, é menos movimentado. Já no Lago Azul eu sou contra algumas coisas, por exemplo, tirarem as casas para fazerem pracinhas em vez de fazer alguma creche ou algo do tipo para o bairro; com as pracinhas vão pessoas para fumarem drogas, não há como crianças brincarem; o lazer e segurança na minha opinião não tem. Uma única coisa boa foi que fizeram saneamento básico entre todos.” - , mora no Jd Eliana com pais e irmã desde 2010, a família foi removida do Lago Azul pela intervenção, 15 anos.

$---$

"Bom, o meu bairro não é um lugar ruim para se morar, é tranquilo e é um bairro pequeno. Antigamente as pessoas faziam muita festa com o som alto demais e isso incomodava a maioria, mas agora todos entraram num acordo e está mais tranquilo. Mas do meu ponto de vista gostaria que meu bairro tivesse áreas mais verdes ou de lazer para os moradores porque isso não tem no meu bairro." - mora com tia e dois irmãos no Jd. Ideal desde 2008, 15 anos.

$---$

“Antigamente esse bairro era um caos. Antigamente era mato, esgoto,, pouco moradia... Conforme o tempo foi passando, foi mudando pouco para melhor e pouco para pior... Pouco tempo atrás tiraram umas casas perto da represa, agora está em obra, estão arrumando os esgotos, colocando asfalto, aos poucos vai dando resultado. Não gosto do meu bairro pois os moradores não ajudam, não colaboram com nada, tudo bagunçado. Enfim, esse bairro tem tudo para melhorar mas falta os moradores ajudar." - mora com mãe e irmã no Jd. Monte Verde, 15 anos.

$---$

"Meu bairro é um bairro que precisa de muita melhoria, um bairro onde as pessoas passam por dificuldades sem reclamar, pois eu acho que por elas passarem dificuldades sem reclamar, são pessoas que tem razão de pedir ajuda sem ser desrespeitada. Um lugar onde acontece acidentes, mortes, brigas, intrigas que nesse caso uma coisa que em todos os lugares tem, mas sempre sabemos lidar com esse tipo de problema. Meu bairro é um lugar onde não tem o que reclamar (sobre algumas coisas), um lugar bem agitado, um lugar onde as pessoas se dão muito bem, um lugar onde as pessoas sabem tratar as outras com respeito. O que eu tenho que reclamar é uma bcoisa onde todo mundo do Brasil reclama, são a falta de atendimento nos postos, pessoas com necessidade de um atendimento nos postos de saúde, ruas onde acontece bastante acidentes pelos fato de não ter uma calçada definida, casa que precisam ser reformadas, mas muitas pessoas não tem condições. 
Meu bairro é um lugar que apesar dessas dificuldades, as pessoas tentam achar uma forma de ajudar uns aos outros, por mais que muitas pessoas acham que isso é impossível acontecer, eu tenho certeza de que tudo isso é possível. Pois essa é a minha opinião sobre o meu bairro, e a última coisa que acho que não só no meu bairro mas sim em outros lugares deveria não ter é os zé povinho que não da paz pra sociedade." - mora no Cocaia com mãe, padrasto e quatro irmãos, 16 anos.

$---$

"O meu bairro eu acho que é um bom lugar para morar só que temos muitos problemas como:falta de moradia, calamidade pública, falta de saneamento básico, e temos muitos problemas em nossas UBS. Sim, não tenho o que criticar do bairro Cocaia, mas temos muitos problemas com acúmulo de pessoas no transporte público. Nós já somos uma comunidade, quando eu falo de comunidade falo do bairro todo. Nós somos uma comunidade muito carente aqui no bairro temos várias ruas sem asfalto ou asfaltada pela metade. Em pleno século 21 temos casas em cima de córregos, casa a beira das represas, mas na verdade aqui onde nós moramos os maiores problemas são: os hospitais e a falta de moradia, tem pessoas que moram aqui no bairro e não reclama de onde mora mas sim do transito que pegam para ir até a estação de trem mais próxima." - mora com a mãe no Cocaia, 17 anos.

$---$

"Quando ando no meu bairro a única coisa que consigo sentir é angústia e nojo, pois em minha rua tem muito esgoto e lixo nas ruas, onde as pessoas não conseguem cuidar ou preservar o matrimo [patrimônio] público." mora no Cantinho do Céu com mãe e filha de 7 meses, 16 anos.

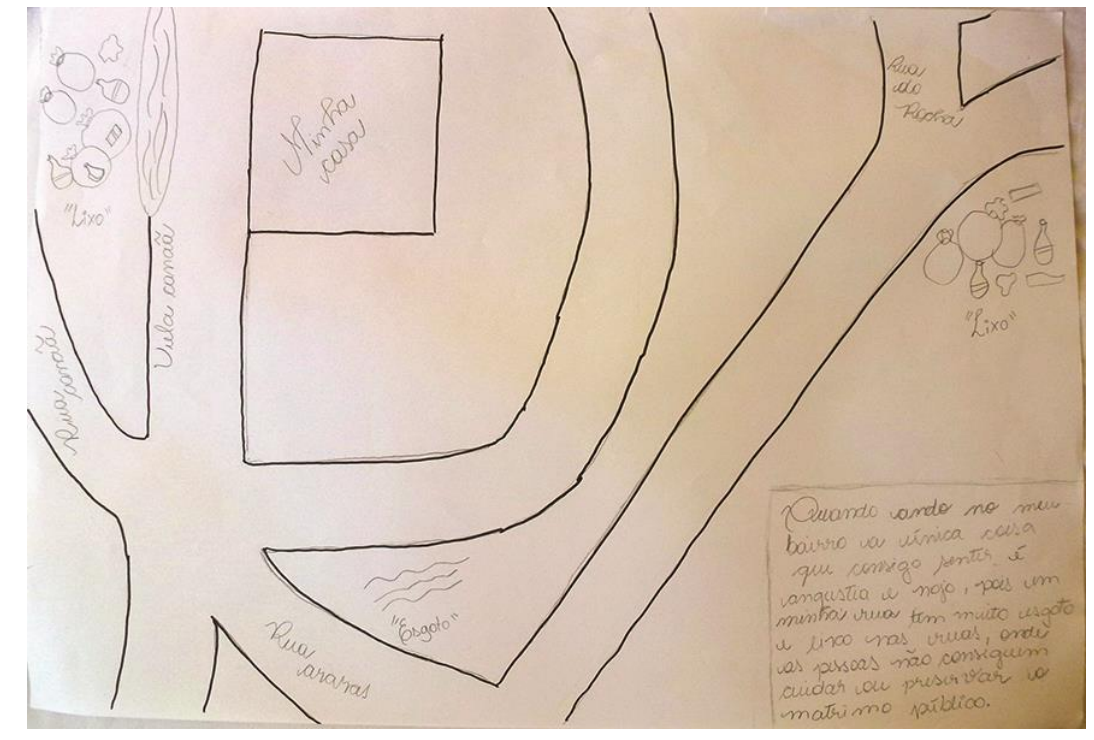

"Fiz o desenho de uma pequena parte do meu bairro, um bairro que apesar de ser meio perigoso as vezes, e ruim para sair de buzão para trabalhar por causa do trânsito na belmira. Não sei se gostaria de sair, pois a minha família praticamente toda mora aqui."

- mora com pais e irmãos no Cocaia, 17 anos

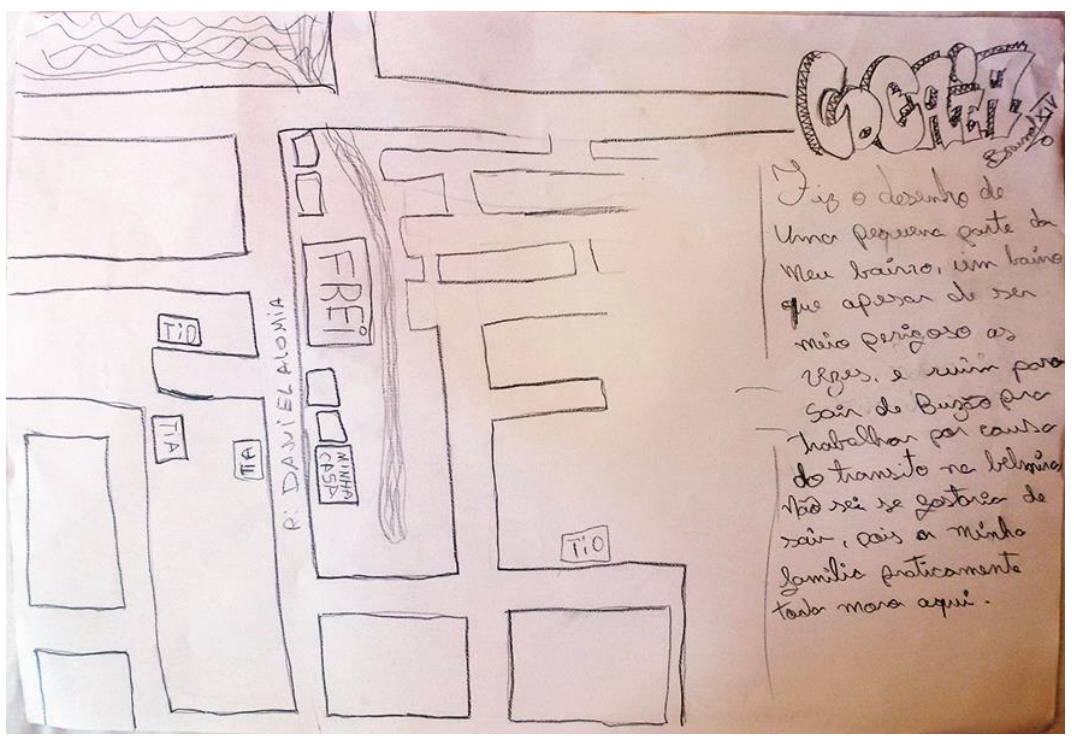


“Não gosto do meu Bairro...

Tem muito lixo, muito barulho, muita gente que acha tem todo tempo do mundo pra reparar os erros que existem aqui.

Gente que não quer nada com nada, que só pensa em coisas fúteis E não procuras melhorias, Afinal, quem mora aqui é a gente.

Meu bairro precisa de melhorias Mas quando a prefeitura faz algo bom As pessoas destroem e não estão nem aí...”

- mora com pais no Jequirituba, 15 anos

\section{Nẫ gasto volo unew Basioco..}

Tiem muito lico, unuito clarularo,

unuita gente rques laceras tem tóolo

Ltempo do mundo y pras re parcar

cos urros uque wastom uoqui.

Guente queo mä uque unodw lcom unodo

Que iso ypentsar uns vorsiak futis

$\mathcal{L}$ mă yprocuram milhoviaz,

Alfinal, quem merar woqui cé a gente.

Mlew baviro yprecisa de melongrial

mass rquando a voreleitura tag ago

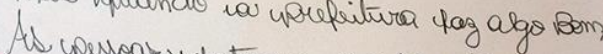

ai unä̀ ustas mem

$\therefore v$

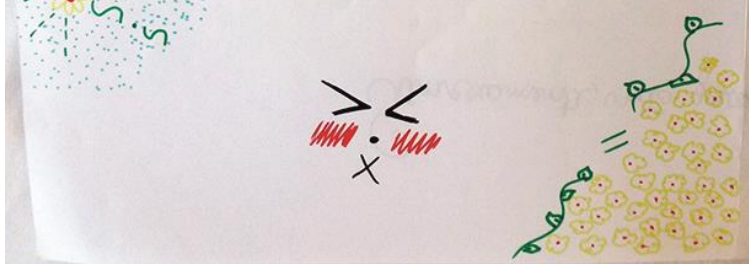




\section{OfICINA 2 - REALIZADA DIA 06/05/2014, TERC̣A-FEIRA, Às 14H}

O segundo dia de oficina contou com sete participantes, apenas um correspondia ao sexo masculino e este não havia participado do primeiro dia. A oficina foi preparada de acordo com a discussão e material produzido no dia de atividades anterior. Num primeiro momento, agrupei os desenhos e textos de acordo com o bairro de moradia de cada um dos participantes, com características urbanísticas similares e de proximidade territoriais: (1) Jd Eliana/Jd Ideal; (2) Cantinho do Céu; (3) Jequirituba/Monte Verde e (4) Cocaia. O conteúdo foi categorizado entre aspectos positivos (em tarjeta verde) e negativos (em tarjeta vermelha). A ideia da classificação buscava demonstrar um "sentimento" inicial revelado em relação ao bairro em que se mora; o intuito era indagá-los ao provocar uma reflexão em relação ao que é dito, narrado sobre o seu local de moradia. A representação em torno de um valor positivo ou negativo incide num imaginário coletivo que se forma sobre os bairros.

No segundo momento, dividi os sete participantes em dois grupos. Em uma base cartográfica impressa do Google Maps, solicitei a indicação dos bairros, os percursos feitos cotidianamente, os locais agradáveis e desagradáveis. Como a conversa reinou durante a atividade, apenas a indicação dos bairro e os percursos foram mapeados. Além disso, a base disponibilizada focalizando apenas a península do Cocaia - se mostrou insuficiente nesse deslocamento cotidiano, pois muitos circulavam além dessa delimitação.

Os slides apresentados foram os seguintes:
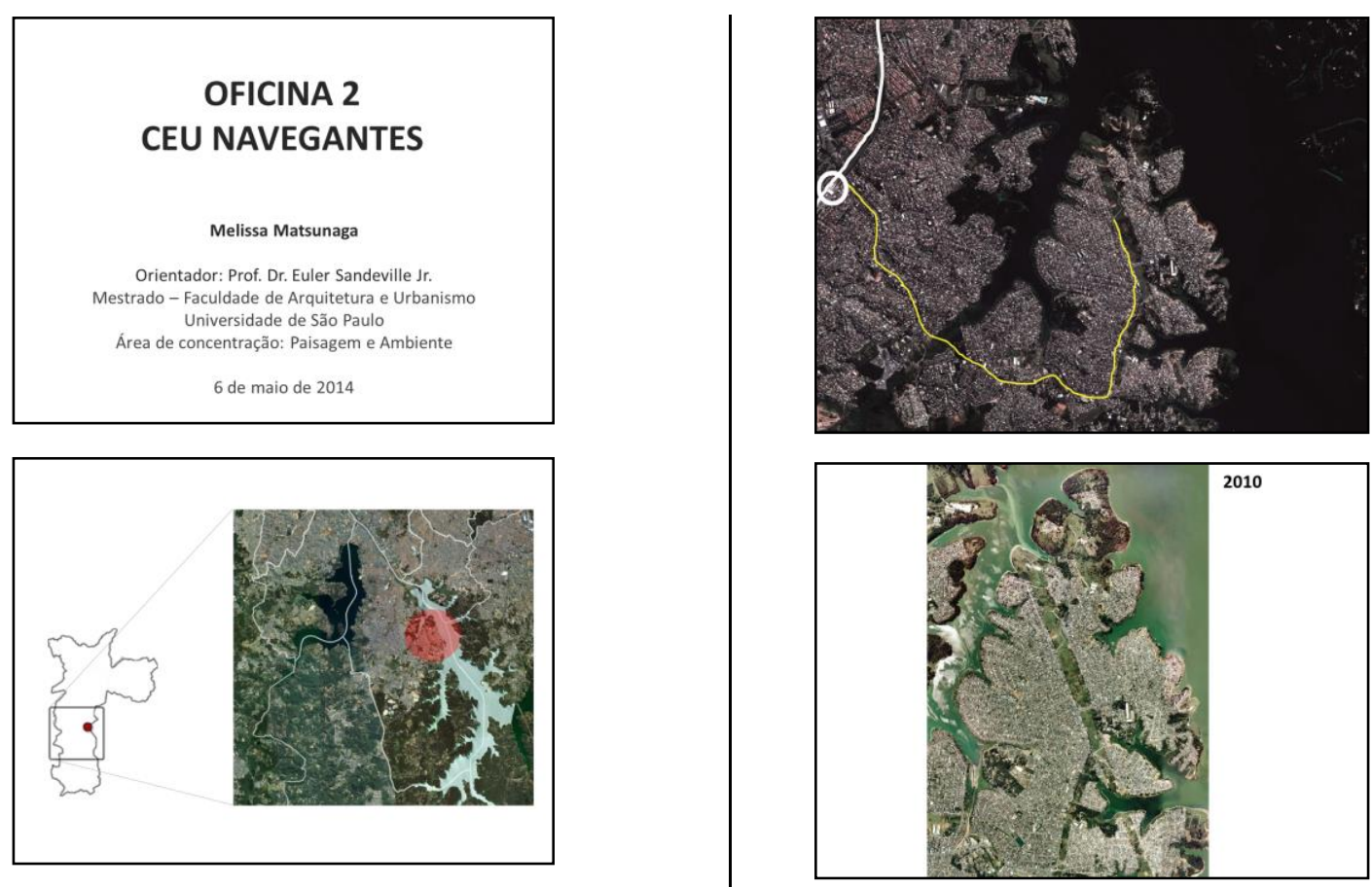

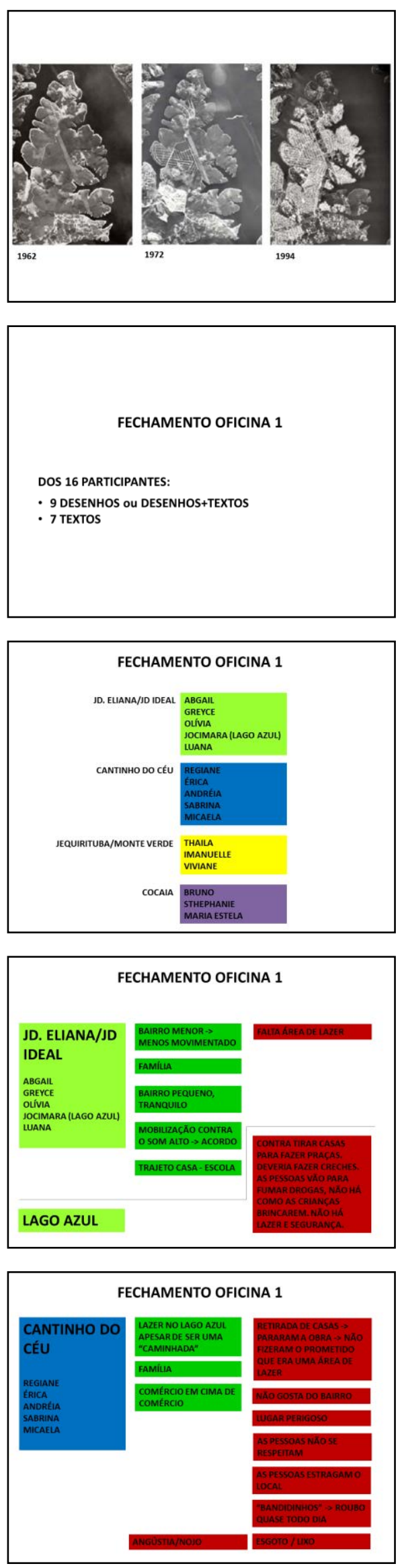
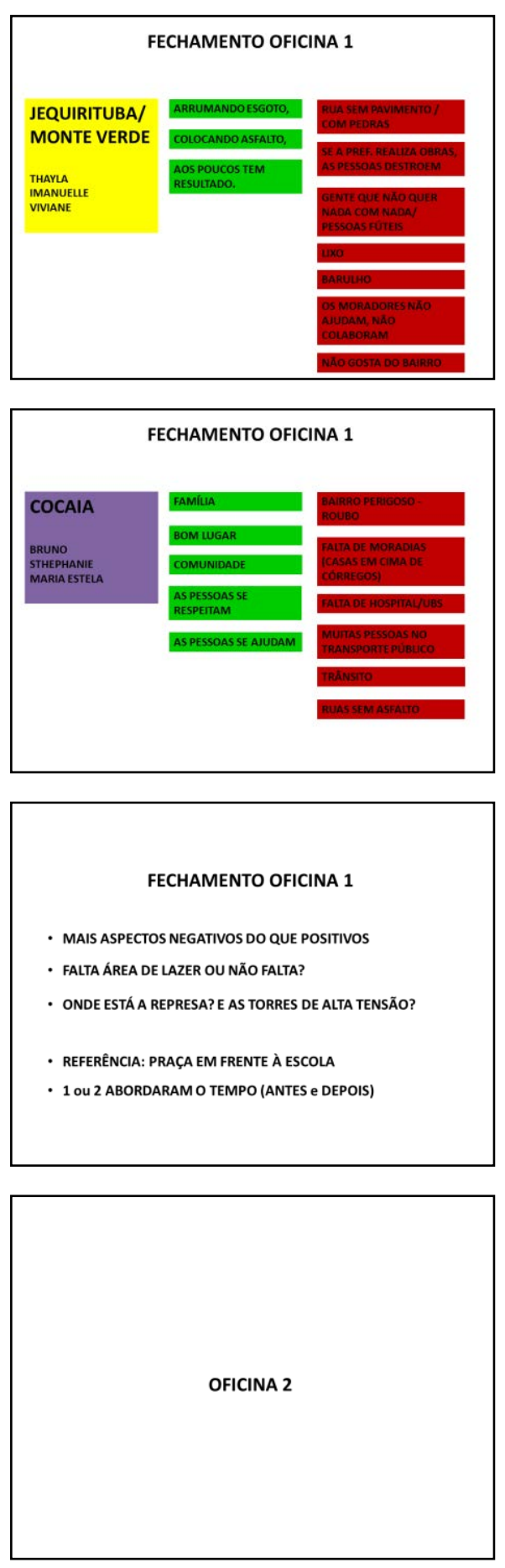

OFICINA 2
EM GRUPOS:
1. DELIMITAR OS BAIRROS
2. INDICAR OS PERCURSOS DE DIA DE SEMANA E FINS DE SEMANA
(INDICAR OUTROS BAIRROS, SE HOUVER)
3. INDICAR ÁREAS DE LAZER / COMÉRCIO / ESCOLA / UBS
4. LUGARES AGRADÁVEIS (E POR QUE SÃO AGRADÁVEIS?)
5. LUGARES DESAGRADÁVEIS (E POR QUE SÃO DESAGRADÁVEIS?)
6. LUGARES QUE PODERIAM SER DIFERENTES? COMO?


O seguinte material foi produzido no segundo dia da Oficina:

\section{Grupo 1}

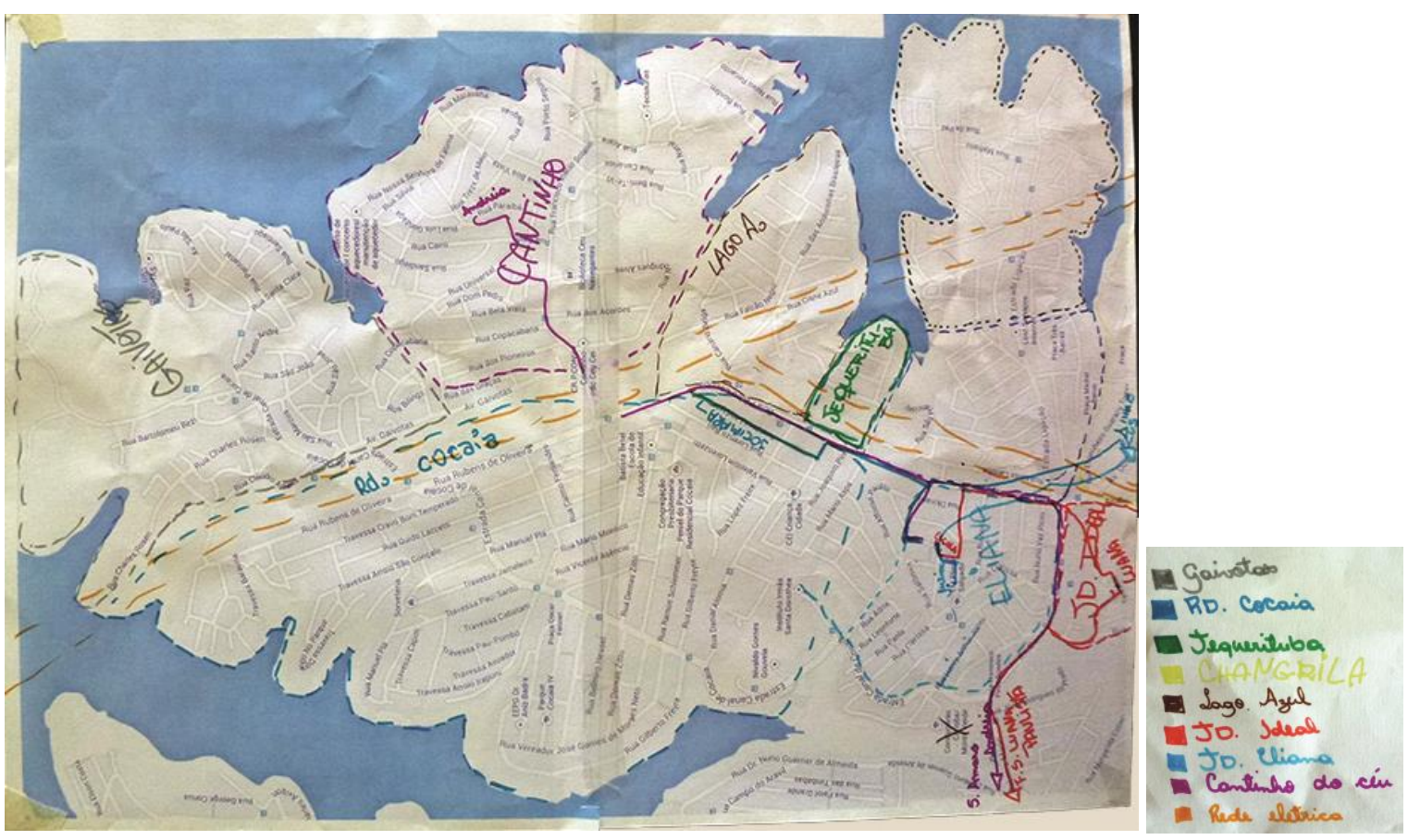

\section{Grupo 2}

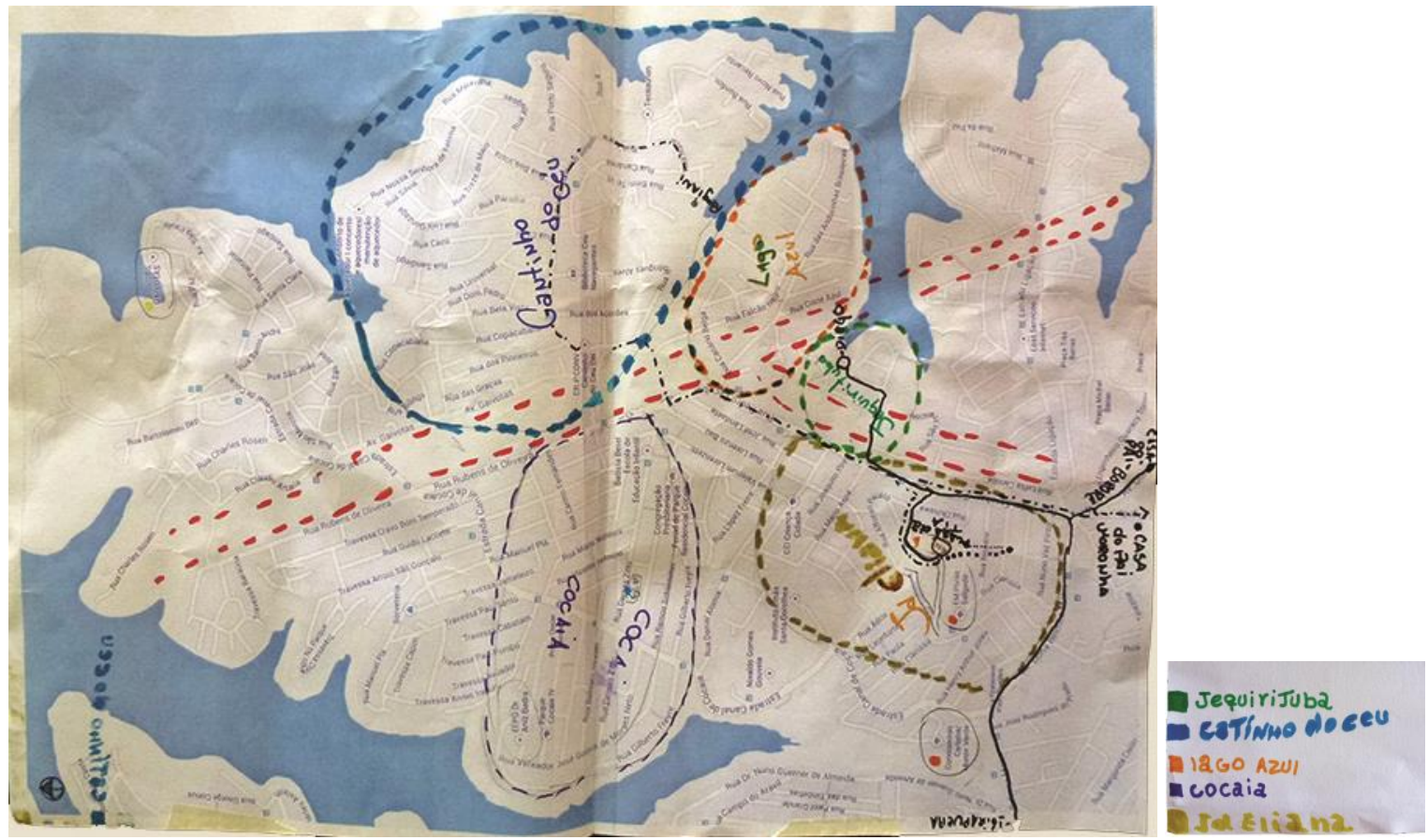




\section{OfICINA 3 - REALIZADA DIA 13/05/2014, TERÇA-FEIRA, Às 14H}

O terceiro e último dia da oficina contou com apenas cinco participantes, todas do sexo feminino. Como feito na oficina anterior, na primeira parte realizei o resgate da discussão e conteúdos apresentados. A partir de então, o foco residiu no Lago Azul com as transformações ao longo do tempo utilizando fotos históricas do Google Earth, de 2008 a 2013, indicando as remoções das casas e o surgimento da obra do parque linear. Esta escolha partiu da discussão realizada na atividade precedente: um dos aspectos que chamou a atenção foi que, apesar dehaver um parque na região, ele não era visto como área de lazer, ou seja, os adolescentes não o utilizavam alegando a presença de drogas e falta de segurança, diziam eles: “o parqueé uma biqueira”. Em contraposição à escola em que estudavam, E.E. Maria Luiza, ser um local indicado como agradável, ou positivamente, já que era onde se encontravam e conversavam. O CEU existente no Cantinho do Céu também foi indicado como um espaço positivo, segundo eles “o problema era chegar até o CEU”.

Essa dimensão valorativa dos espaços coletivos (parquelinear e escola) evocada na oficina 2 e dos bairros evocada na oficina 1 cindiu as possibilidades do encaminhamento do que se pretendia da oficina. Percebi que abordara dimensão coletiva do espaço público era aspecto mais interessante do que o cotidiano dos bairros em si, uma vez que o elemento diferenciador nos bairros remetia à presença da infraestrutura urbana. Além do fato que nem todos conheciam os bairros dos colegas, o que limitava a discussão praticamente no trajeto entre a escola e a casa. Com o intuito de provocar a discussão, na segunda parte da oficina neste dia, dividi a turma em dois grupos e sugeri que mapeassem então a localização de ocorrências no parque linear, de venda de drogas ou lugares inseguros e quais as soluções que eles indicariam para tentar melhorar essa condição negativa.
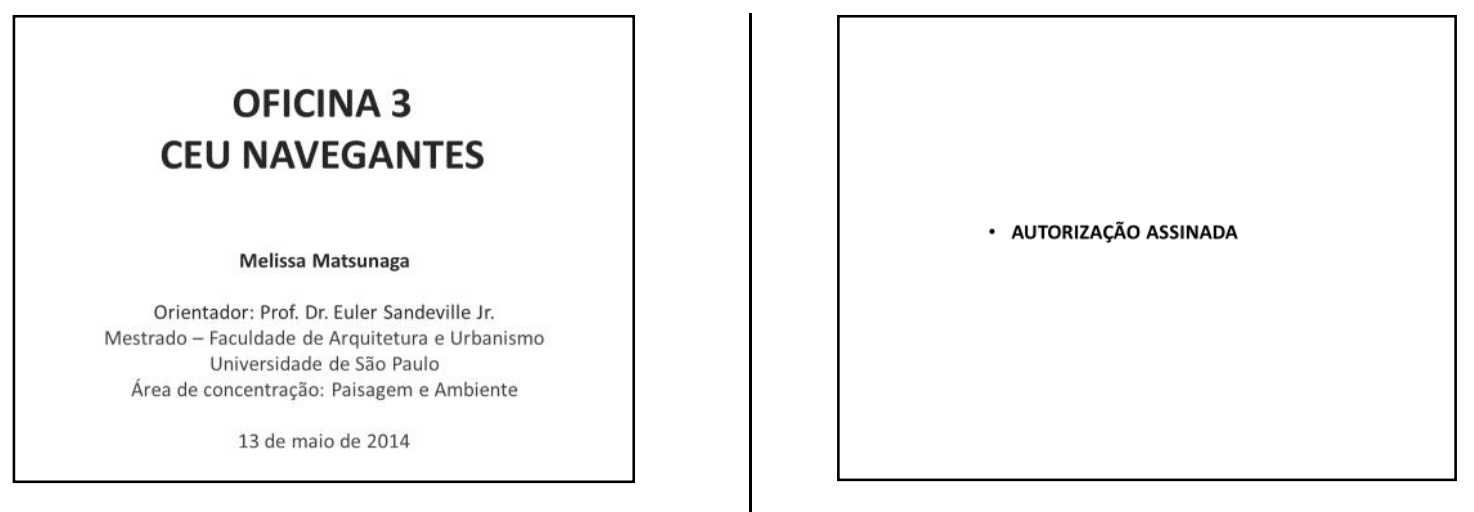

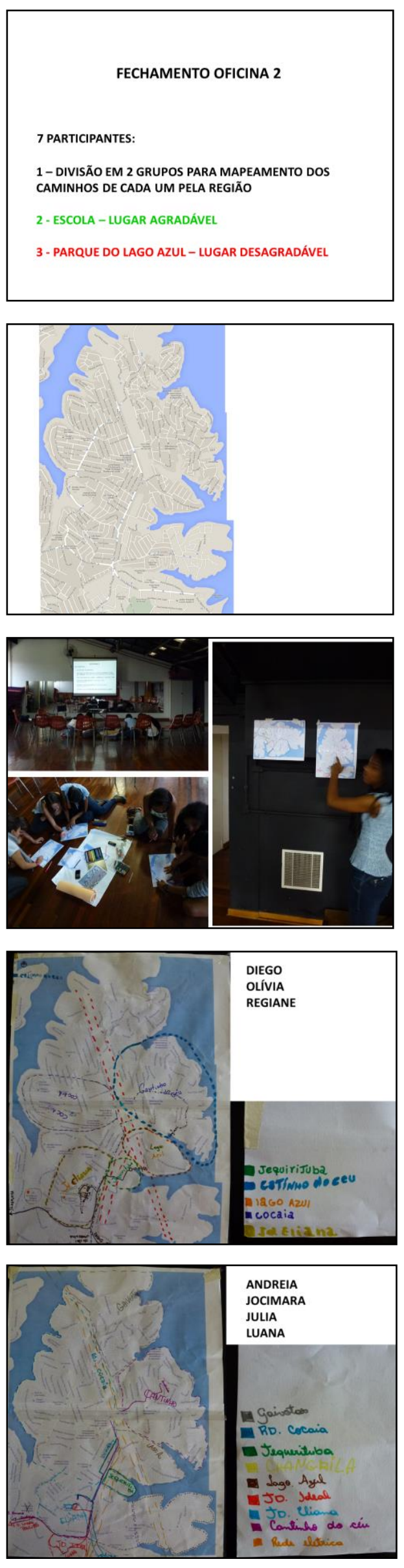
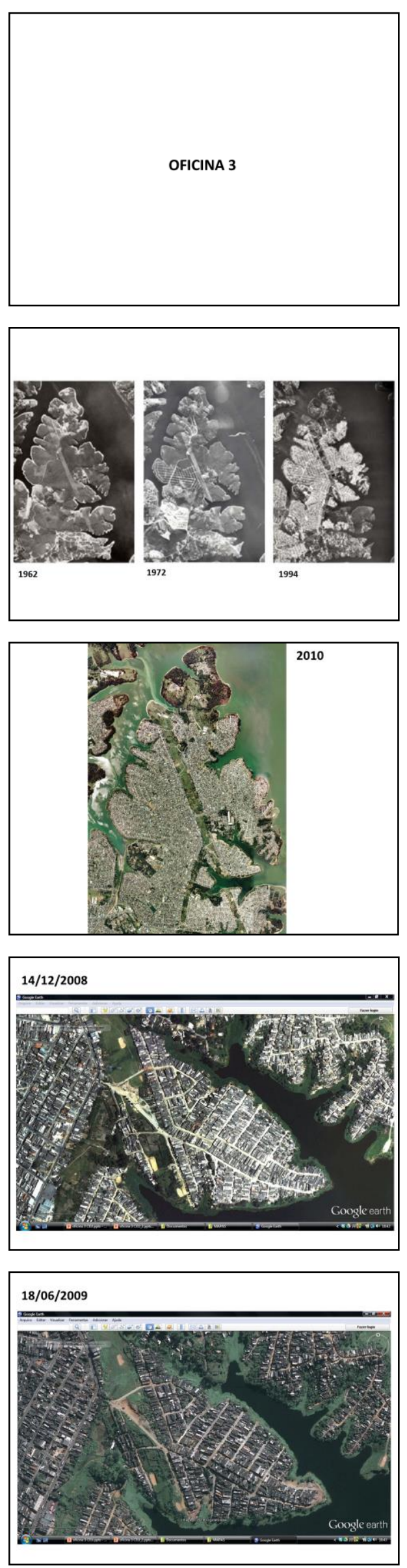

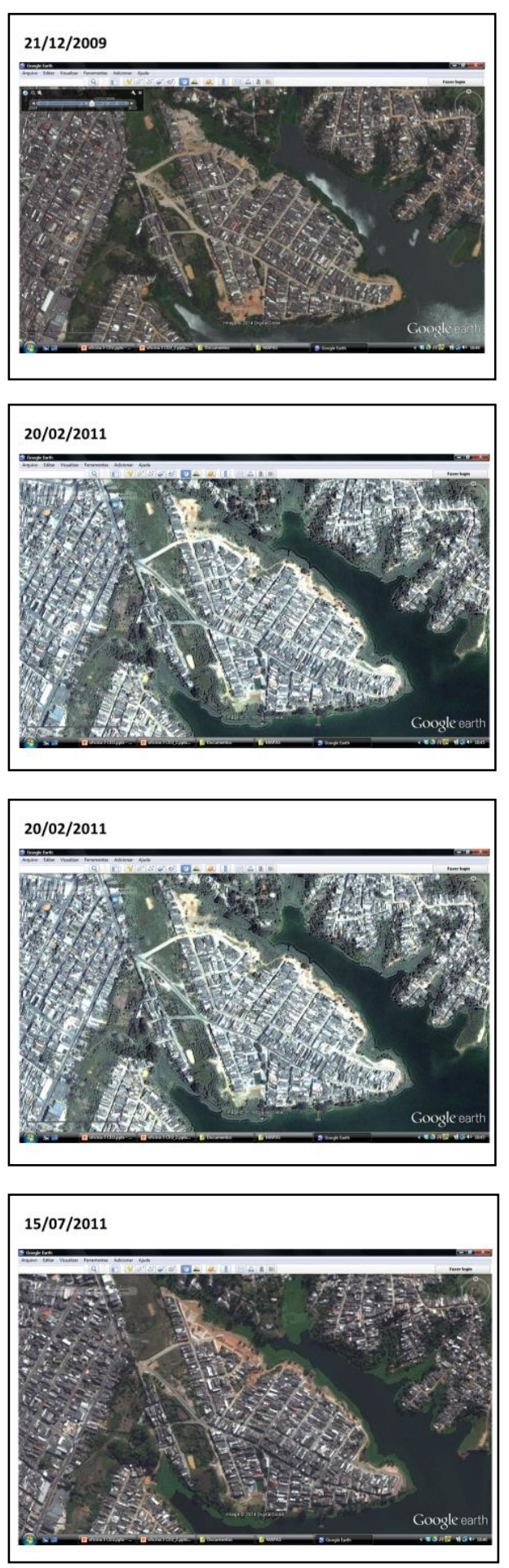
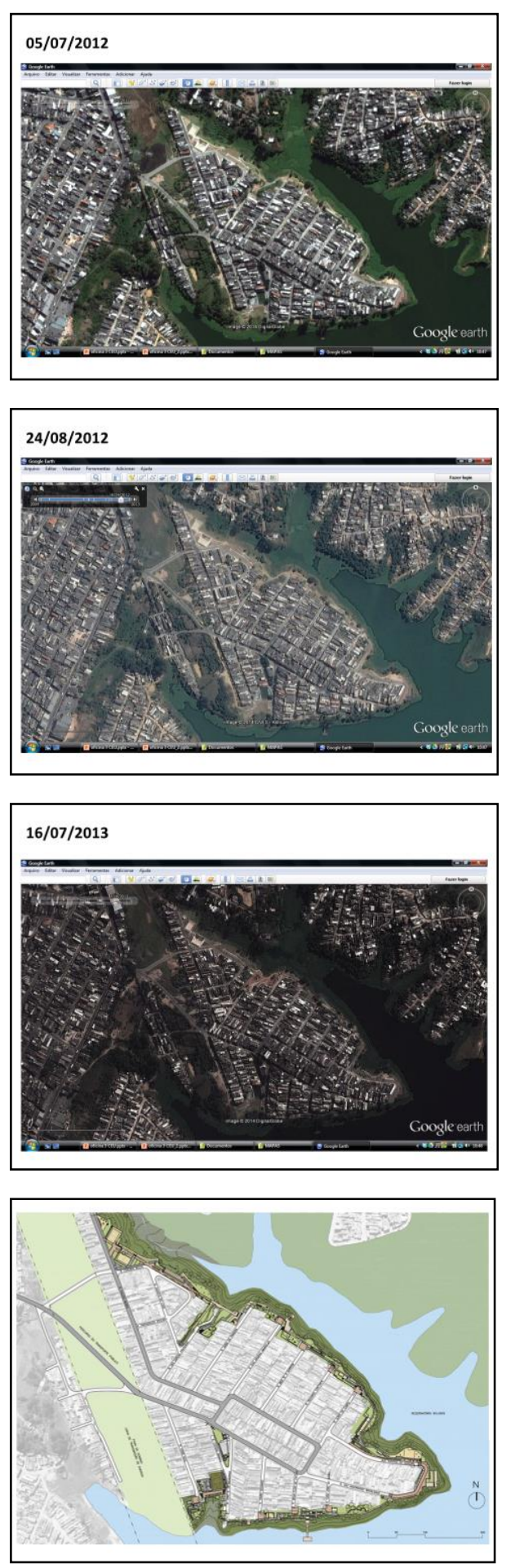

Divididas em dois grupos, o material produzido ao fim do terceiro dia de oficina foi o seguinte: 
Grupo A
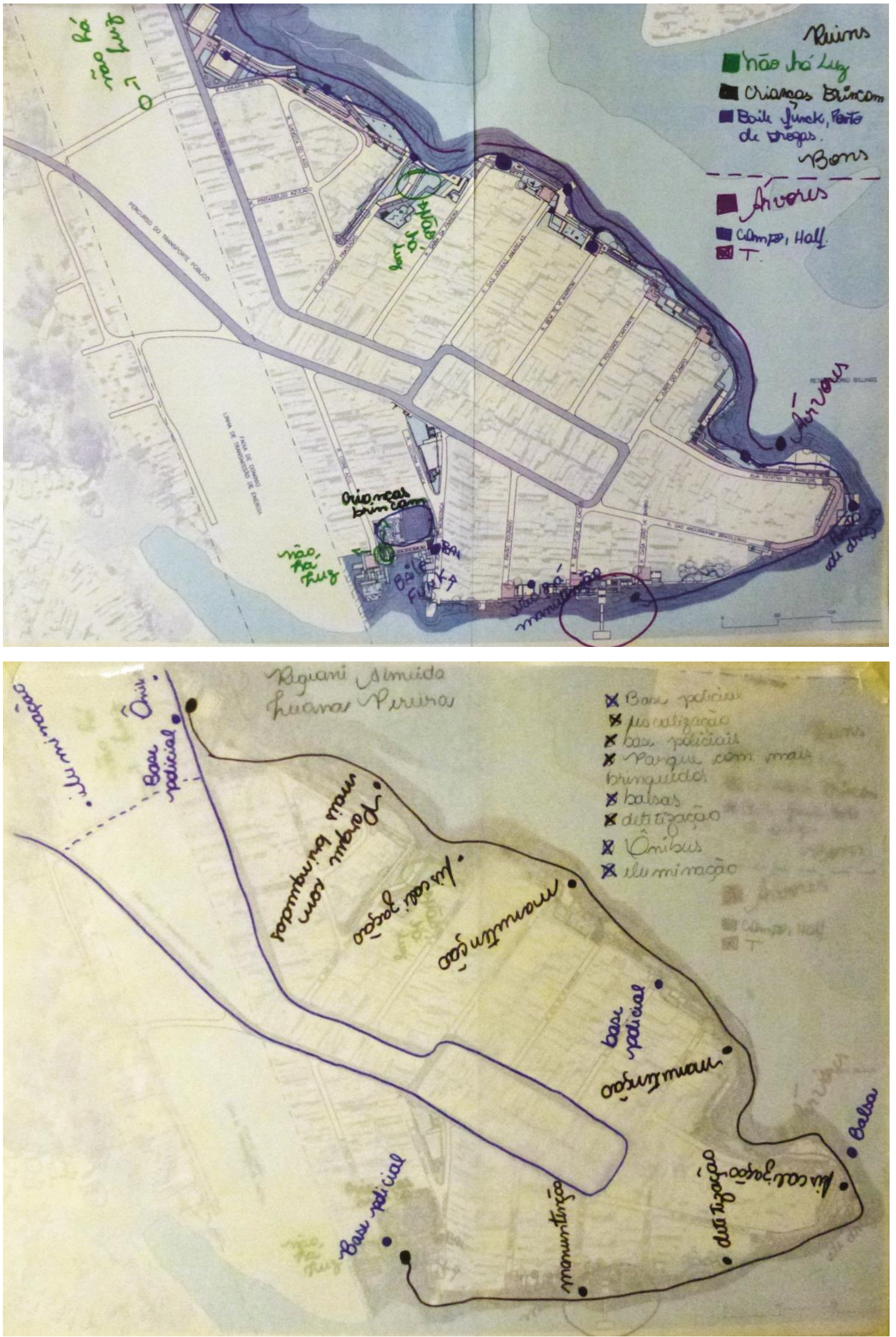
Grupo B
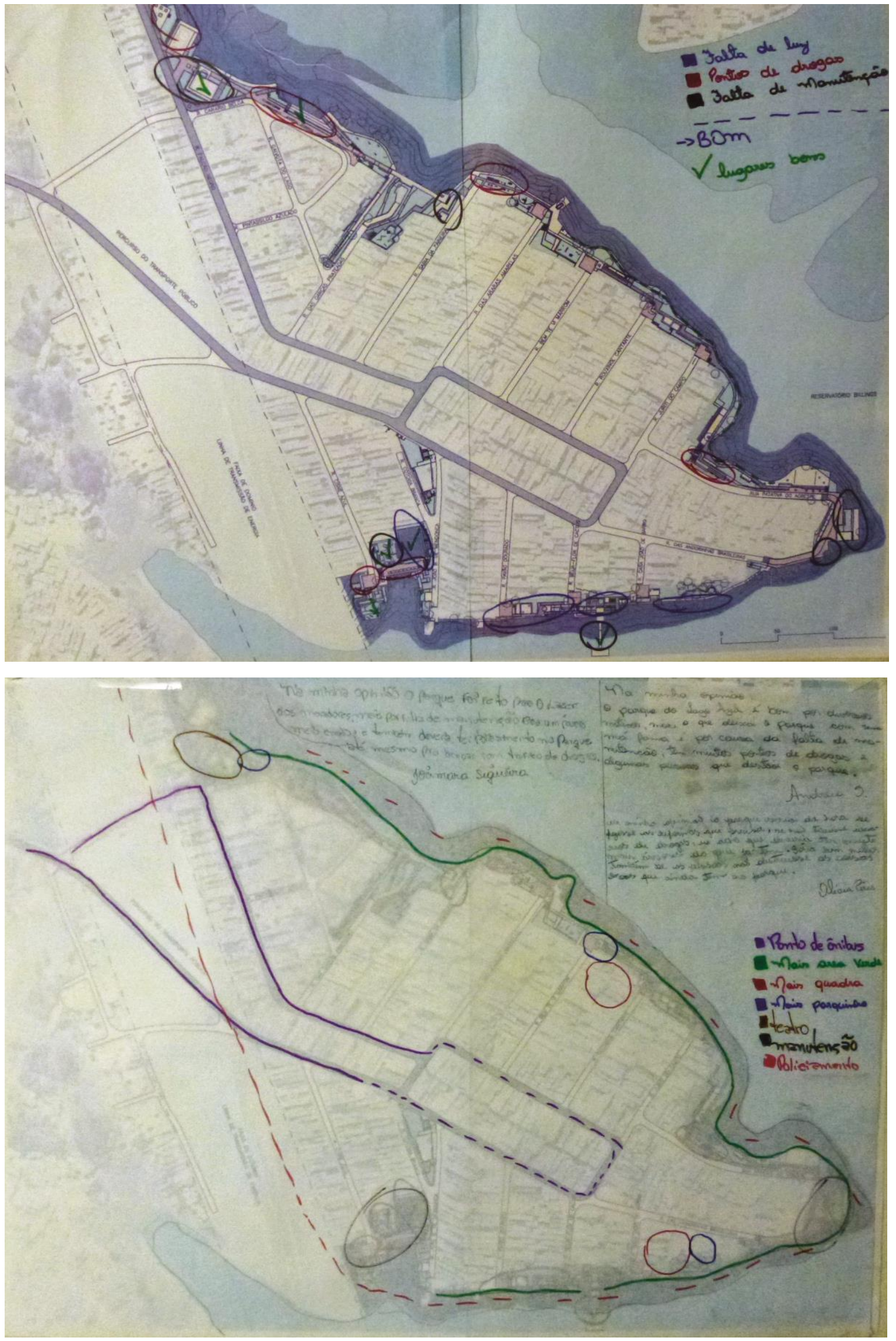



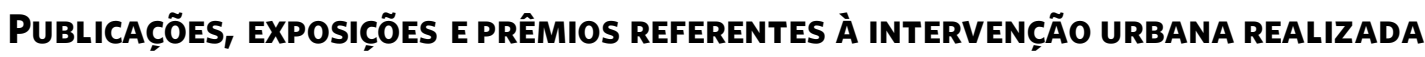 (POLÍTICA PÚBLICA, PROGRAMA, PROJETO, OBRA)}

\section{Publicações institucionais}

Publicação oficial da SEHAB/PMSP "Entre o Céu e a Água" lançada no final de 2012 trata sobre o projeto realizado e resgata desde o histórico da região até depoimentos de moradores:

BARDA, Marisa.; FRANÇA, Elisabete (Org.). Entre o céu e a água: o Cantinho do Céu. São Paulo: HABI Superintendência Habitação Popular, $2012 . \quad$ Disponível em: www.habisp.inf.br/theke/documentos/publicacoes/cantinho_do_ceu/files/livro-cantinho-do-ceu.pdf. Acesso em 7 nov 2014.

Em 2009 a publicação do livro "Operações Táticas", parceria entre SEHAB/PMSP e Universidade de Harvard, que consistia em propostas urbanísticas para o enfrentamento da urbanização precária do assentamento:

WERTHMANN, Christian. Operações táticas na cidade informal: o caso do Cantinho do Céu. 1a. Ed. São Paulo: Prefeitura do Município de São Paulo. Secretaria Municipal de Habitação - SEHAB, 2009. Disponível em: www.habisp.inf.br/theke/documentos/publicacoes/operacoes_taticas/index.html. Acesso em 7 nov 2014.

\section{Periódicos}

Revista Arquitectura Viva - Brasil construye, Acuífero social - Urbanización Cantinho do Céu, São Paulo. Número 144, Madri, Espanha, 2012, p. 32-35. (www.arquitecturaviva.com)

Revista A+T - Reclaim Remediate Reuse Recycle, Introduction of sewerage systems into the informal city. Número 39-40, Vitoria-Gasteiz, Espanha, 2012, p 84-85. (www.aplust.net)

Revista A+T - Reclaim Remediate Reuse Recycle, Introduction of public space into the informal city. Número 39-40, Vitoria-Gasteiz, Espanha, 2012, p 86-87. (www.aplust.net)

Revista Domus, No 963 - Suplemento São Paulo Calling, Cantinho do Céu calling Medellín, Rozzano, Italia, 2012, p. 34-41.

Revista Infraestrutura urbana, Urbanização da Billings. Número 14, São Paulo, Brasil, 2012, p. 28-33. (www.piniweb.com.br)

Revista Monolito - Habitação social em São Paulo, Cantinho do Céu. Edição No. 7, São Paulo, Brasil, 2012, p. 66-73. (www.revistamonolito.com.br)

Revista Projeto Design, Intervenção na orla da represa abre vista para a paisagem . Número 369, São Paulo, Brasil, 2010, p. 76-81. Disponível em: arcoweb.com.br/projetodesign/arquitetura/boldariniarquitetura-urbanismo-parque-publico-19-01-2011. Acesso 01 out 2014.

Revista Sãopaulo (suplemento do Jornal A Folha de São Paulo). Cantinho do Céu em Veneza. p 33-34. São Paulo, Brasil. Edição de 29/08/2010.

\section{Periódicos On-line}

Archdaily Brasil - Urbanização do Complexo Cantinho do Céu. http://www.archdaily.com.br/br/01157760/urbanizacao-do-complexo-cantinho-do-ceu-boldarini-arquitetura-e-urbanismo. Acesso 04 set 2014.

Landezine Landscape Architecture Works - Cantinho do Céu Urbanization by Boldarini Arquitetura e Urbanismo. Www.landezine.com/index.php/2013/11/cantinho-do-ceu-complex-urbanization-byboldarini-arquitetura-e-u rban ismo/. Acesso 04 set 2014. 


\section{EXPOSIC̣̃̃ES}

- "A cidade informal no Século XXI", promovida pela Prefeitura da Cidade de São Paulo. O tema corresponde às propostas e intervenções em áreas de favelas e assentamentos informais. A exposição iniciou em São Paulo, no Museu da Casa Brasileira, em abril de 2010 e teve edições em Recife, Rio de Janeiro, além de Berlim, Londres e Milão. www.cidadeinformal.prefeitura.sp.gov.br/

- Bienal de Veneza/Itália, XII Mostra Internazionale di Achitettura - Pavilhão do Brasil. 50 anos depois de Brasília, 2010.

- IX Bienal Internacional de Arquitetura de São Paulo, Brasil - Suporte digital, 2011.

- $\quad$ 5th IABR Making City, Bienal de Arquitetura de Rotterdam, Holanda, 2012.

- X Bienal Internacional de Arquitetura de São Paulo, Brasil - Modos de fluir - Praça Vitor Civita, 2013.

\section{Prêmios}

- XVII Bienal Panamericana de Arquitetura de Quito, 3o lugar Habitação social e Desenvolvimento Urbano, Equador, 2010.

- Menção Honrosa Premiação IAB-SP, Categoria Habitação de Interesse Social, São Paulo, Brasil, 2010.

- III Melhores da Arquitetura, Categoria Intervenção Urbana. Revista Arquitetura \& Construção, São Paulo, Brasil, 2010.

- Prêmio IX Bienal Internacional de Arquitetura de São Paulo. Prêmio Suporte Digital. São Paulo, Brasil, 2011.

- Menção Especial, Future Cities - Planning for the 90 per cente Celeste Prize, Veneza, Itália, 2012.

- $\quad$ XIV Bienal Internacional de Buenos Aires, Categoria Projeto Urbano. Argentina, 2013. 


\section{AnexOS}

\section{ANeXo A 209}

Capa Revista VejaSP, A São Paulo escondida, 19/06/1991

\section{Anexo B 211}

Carta-denúncia anônima à promotoria em 30/07/1994 



\section{Anexo A}

\section{Capa Revista VejaSP, A São Paulo escondida, 19/06/1991}

Capa da Revista VejaSP, de 19/06/1991 que apresenta foto aérea dos bairros Parque Residencial dos Lagos, em primeiro plano, já formado e Cantinho do Céu, em processo de parcelamento irregular. Acervo Biblioteca Mário de Andrade.

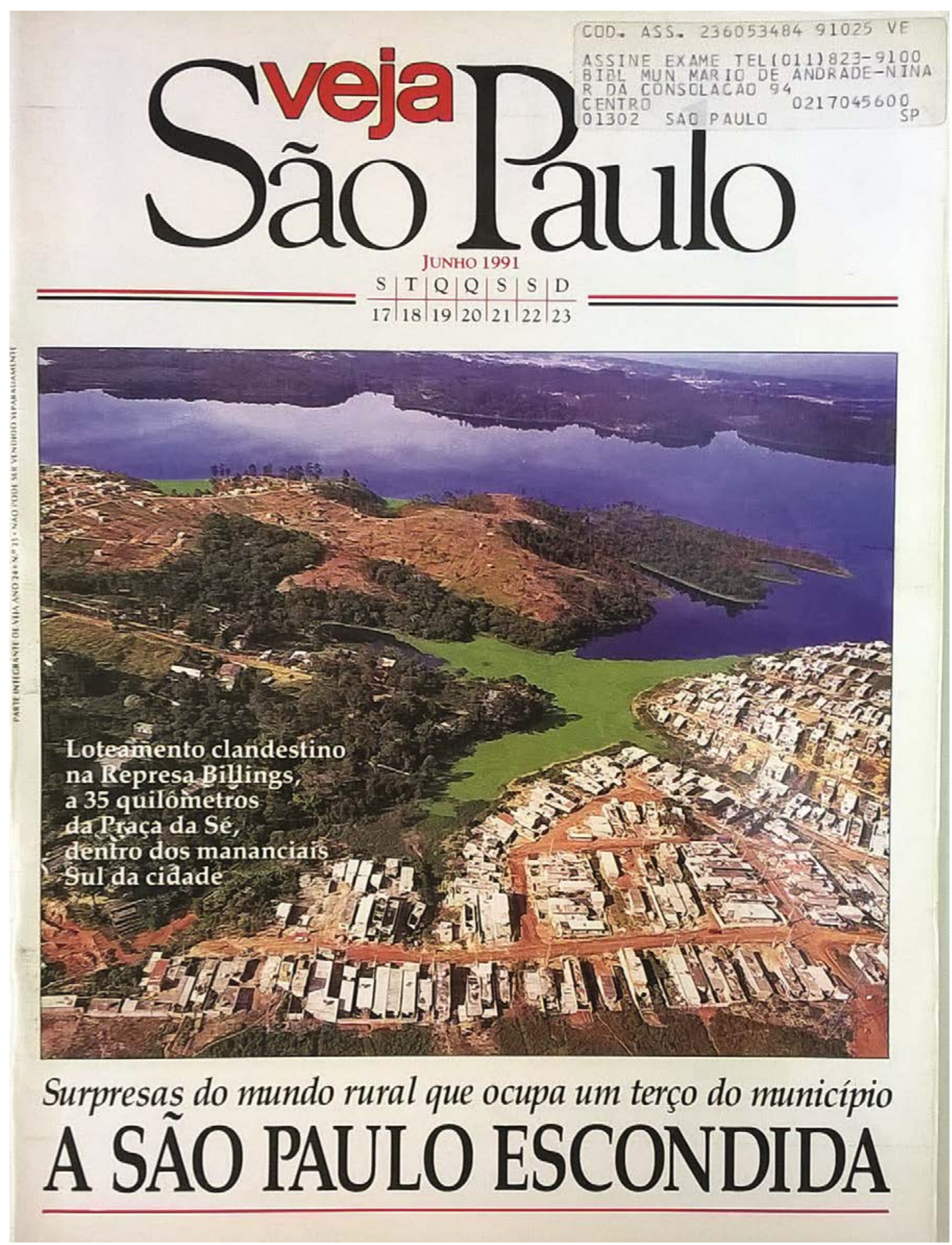





\section{CARTA-denÚNCiA ANônima À PROMOtoria EM 30/07/1994}

Fonte: Processo judicial No. 0405292-44.1997.8.26.0053 - 4ạ. Vara de Fazenda Pública - Foro Central, no Fórum Hely Lopes Meirelles

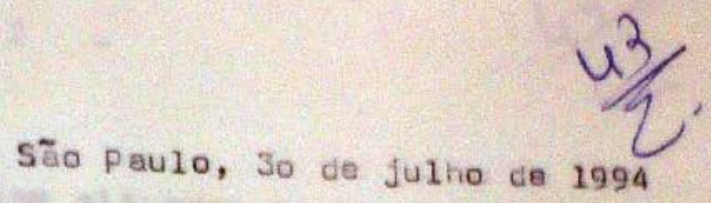

Exelência ;

tendo esgotado todos os recursos que estão ao nosso alcançe, recorrenos através desta ao Exmo. Sr., denunciando o descaso mostrado por parte de autoridades municipais e estaduais, na questäo da proteção as áreas de mananciais. Em te pos que se fela tanto em ecologia, proteção do meio ambiente especialmente des manancíais, vêmo-nos cercados de ignorância, desrespeito, incompetência e atitudes contrárias a esta preocupaçäo. Ume distas atítuces irresponsáveis, por exemplo, a aprovação da "Lei de anistia" dos imóveis irregulares, incluindo squeles em áreas de mananciais.

W6s, proprietários "legltimos" (com escritura registrada) e woradores hấ mais de duas décadas naquela região da Represa silings que abrange os bairros parque Residencial Cocaia, Cantiniso do Celu, Geivotas, Lago Azul e etc., sofremos diariarente con as consequências da ocupação desordenada, com o caos, a violêncla, a sujeira, a favelização, os riscos para - nossa sabde, falta de seguranģa, enfim - não ha maís quelidade de vida. C dispensâvel falar da desvelorização dos imoveis.

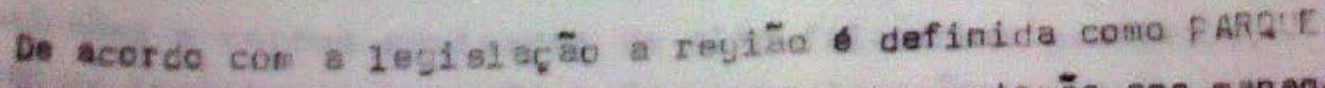
EST nOUAL (proteção florestal e área de proteção aos manancisis. Confiávaros que desta forma as antigos propriedades,

PJ + HURE

Folha 04 


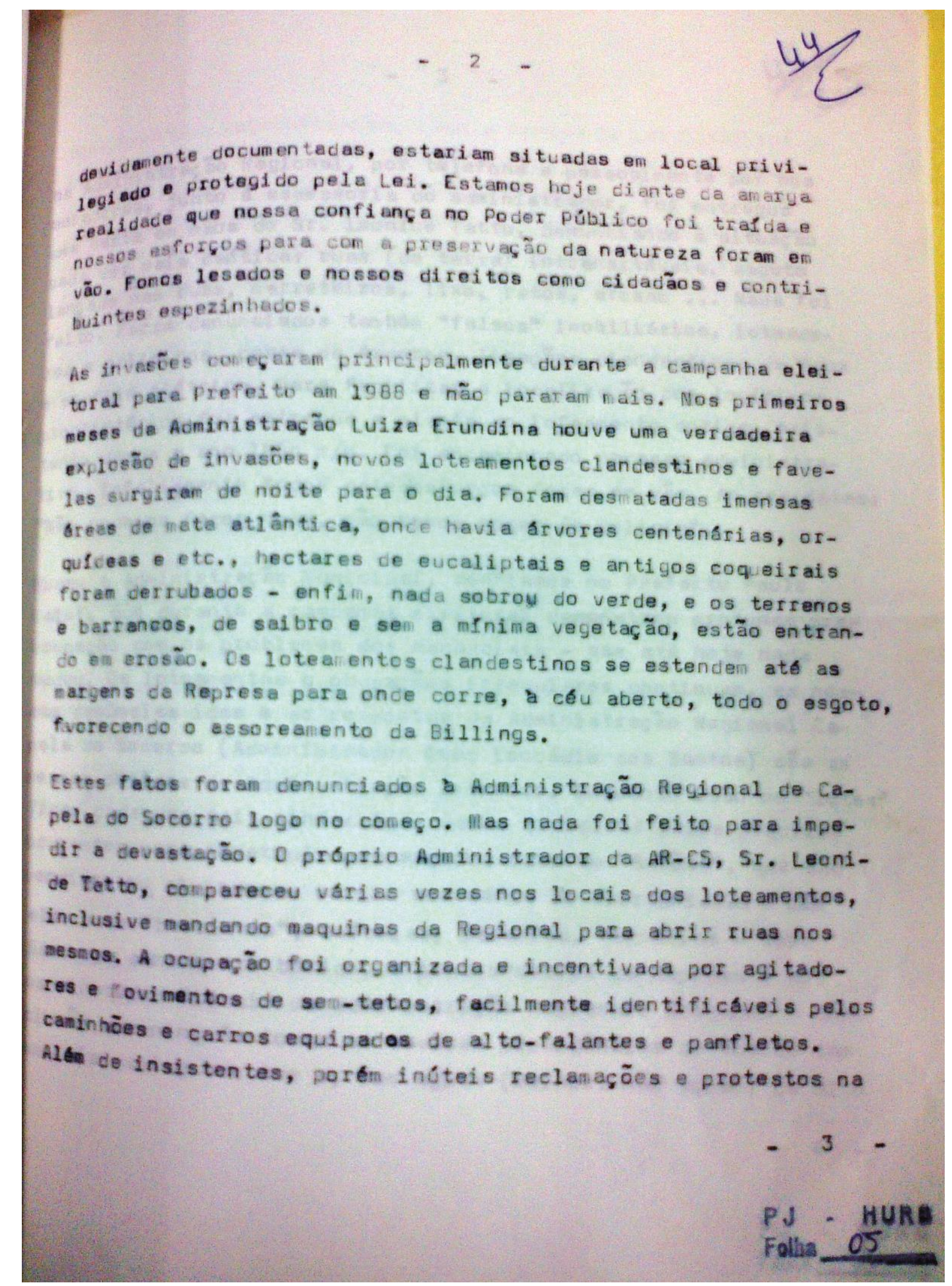




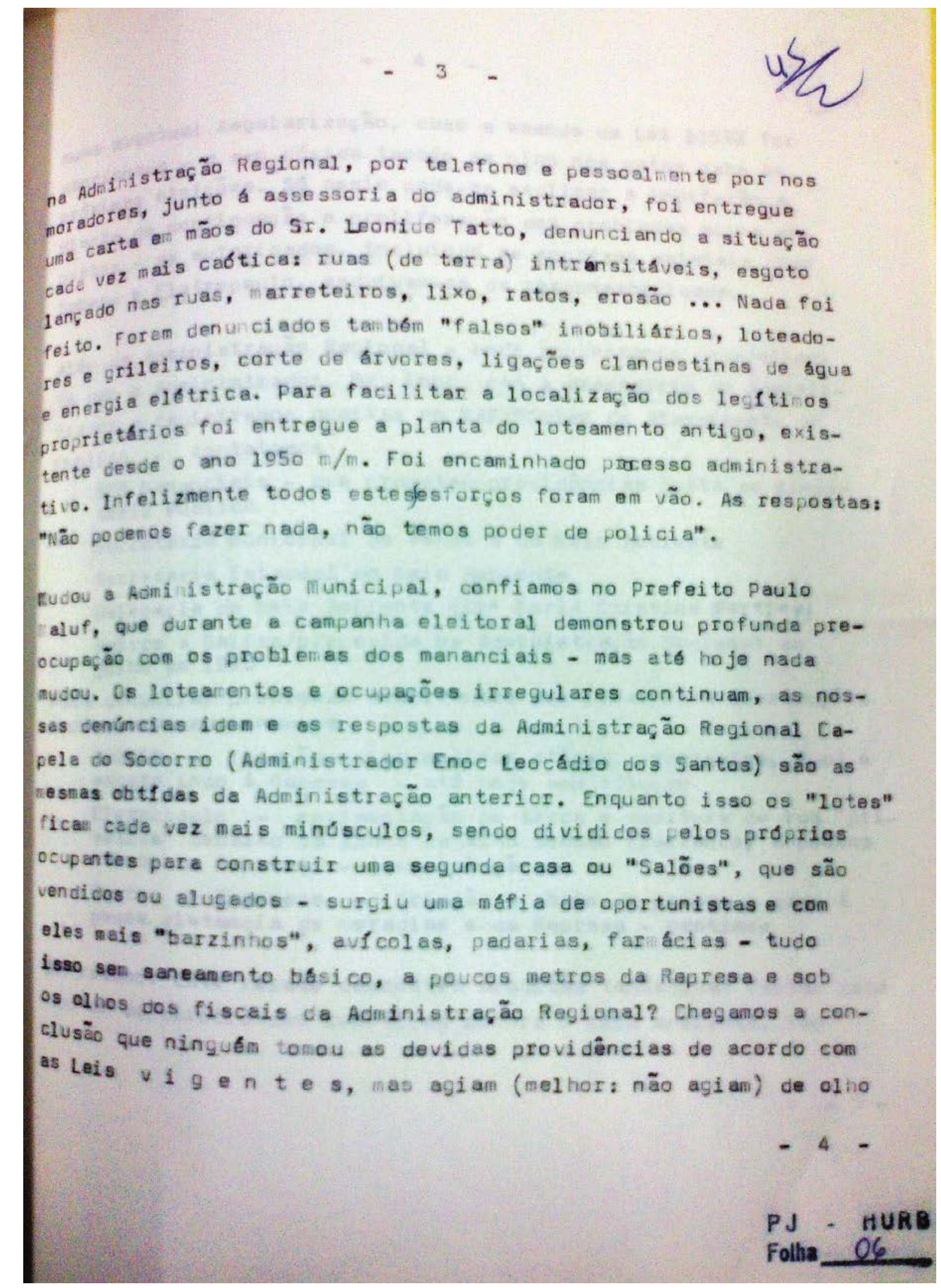


noe ventual regularização, caso a emenda da Lei 11522 for proxises eleiçóes. So assim pode-se explicar a indifera as diante ou continuação proliferaçäo dos problemas acima pestes - as autoricades, incluindo as empresas ostatais como sabesp Eletropaulo, esquivam-se da responsabilicade,

A2t: de Adeinistração Regional - onde conversames pessoalmente con o hoministrador, Sr. Enoc; can a assessoria do Administracer e registramos queixas no NAP/Núcleo de Atendimento ao poblice - contatamos

sos tranenciais - que prometeu providências junto ao ministerio Público

Secretaria Eunicipal do Verde e do li eio Ambiente

Sectetaria Estadual do fieio Ambiente

Delegacia do treio Ambiente (Dr Maria Cristina Martins)

Bairro a Bairro/pronovido na Administração Regional em jul he de 1993

Fara denunciar problemas decorrantes das invasões a construções Arresulares accionou-se

Sheesp - Iigeções clancestinas d’água, vazamentos, água e esgoto indo á Represa - até hoje sem solução

Eletropaulo - movimentaçöo de terra e abertura de rua "privetive" cebaixo da linia ca alta tensão (barrance) a poucos intros da Represe - setl seluçä

Centro de Zoonoses - Criagão e abate da porcos a gado á pouca elstancia de noradias e da Represa - continua

te resuevo: tste relaco denonstra as mutas tantativas feltas para chentez as etrocidades con entidaa contra o meio ambiente. Não 
nedimos esforços nesta luta contra a destruição e, diga-se de passagem, correnos sorios riscos. E é por isso, tenendo represalias, que tenos que recortrer, a contragosto, a envio desta carta anoniana. Contanos com a compreensão ce V. Excia. para a gravidade da nossa si tuaçào.

Aposamos para vossa Exceiencia em busca de apoio pasa una soluça Ifotda, confiando na imparcialidade e integridade da Justiça.

Atenciosahen te

Eoracores de regiễo da

REPRESA EILLTINGS

A Sua Exceléncia, o Senhor

or. Cerlos Alberto Anin Filho

P.D. Pronotor de Justiga

Sho FauL - Capital 